
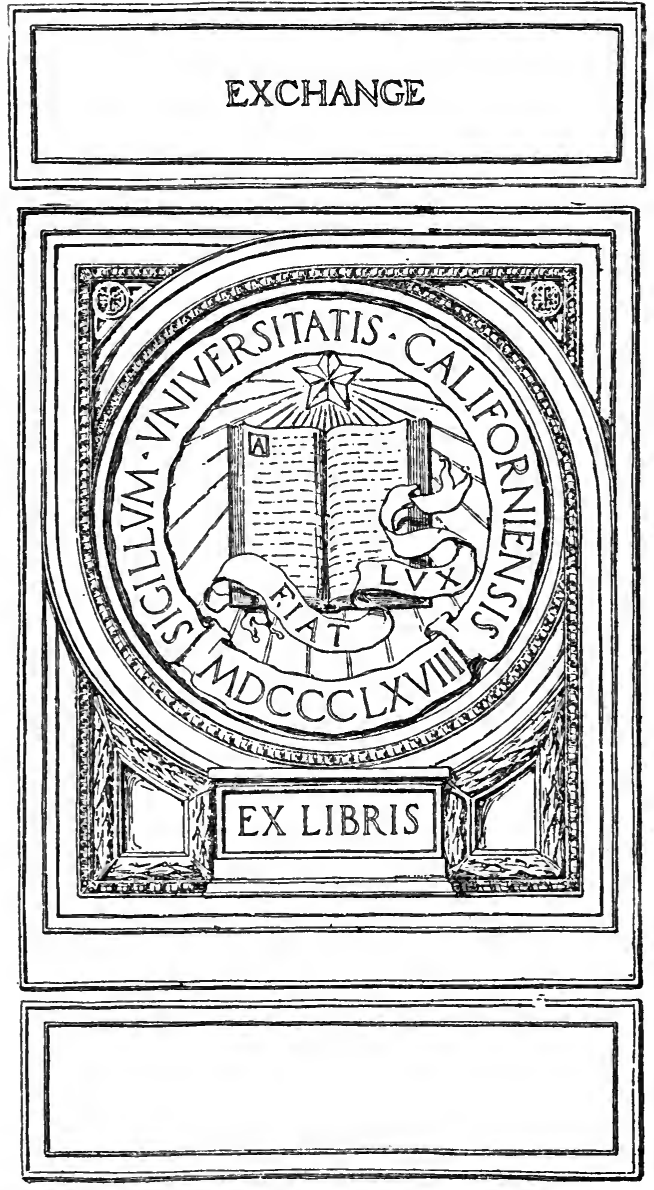

Digitized by the Internet Archive in 2007 with funding from Microsoft Corporation 


\section{A 'HISTORY OF}

\section{THE PRESIDENT'S CABINET}

MARY L. HINSDALE, PH. D.

A THESIS SUBMITTED TO THE FACULTY OF THE DEPARTMENT OF LITERATURE, SCIENCE AND THE ARTS OF THE UNIVERSITY OF MICHIGAN, I9I I

Ann Arbor, Michigan

George WAHR 


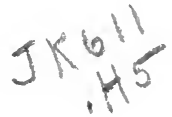

\section{Nutrelli: \\ EXCHANGE}

COPYRIGHT, I9II

BY MARY L. HINSDALE

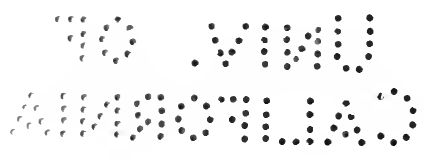

COMPOSED AND PRINTED BY 
To My Mother. 


\section{PREFACE.}

It was upon advice with the late Professor B. A. Hinsdale that the author selected The American Cabinet for the subject of an academic investigation. But the assistance that was to come from one who was both historical scholar and father was soon taken away. The prosecution of the work has been several times postponed. But the period of delay has been one of phenomenal activity among librarians and editors in the field of Americana. And the slow completion has perhaps been justified by the use of larger stores of critical biographies and private papers. The latter kind of material is specially important to the subject; and it is one that, at the best, lags a generation behind current events.

The investigation has been carried on partly as a seminary study at Radcliffe College, and partly by independent research at various libraries. Acknowledgments for many privileges and personal courtesies are due to the gentlemen in authority at the Library of the New England Historic Genealogical Society, the Library of the Historical Society of Pennsylvania, Lenox Library, the Library of the University of Michigan, the Library of Harvard University, and the Division of Manuscripts of the Library of Congress. For information about the inside operations of the Executive, cordial thanks are paid to Mr. Gaillard Hunt, formerly of the Bureau of Citizenship in the Department of State, and to Hon. James Rudolph Garfield, ex-Secretary of the Interior. Valuable academic assistance was received from Professor Andrew C. McLaughlin, both at the University of Michigan and the Carnegie Institution. The highest tribute of gratitude is reserved for Professor Albert Bushnell Hart, one of the most inspiring of instructors. It is through the generosity of the Hon. Wm. L. Clements, regent of the University of Michigan, that the publication of this work has been made possible.

Mary Louise Hinsdale. 


\section{CONTENTS.}

CHAPTER.

- Preface

PAGE.

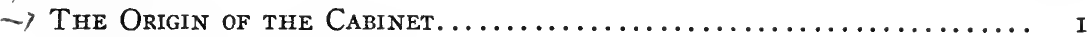

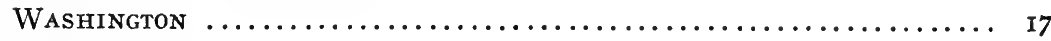

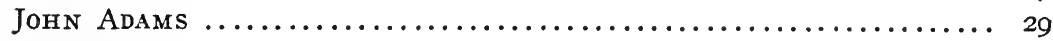

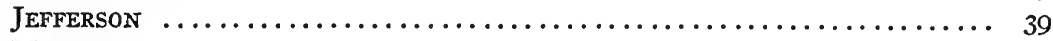

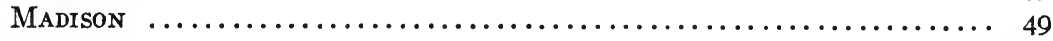

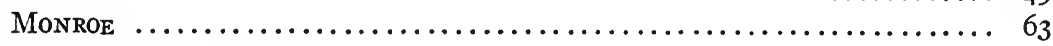

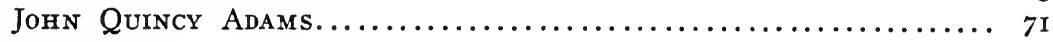

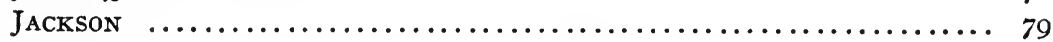

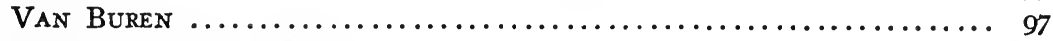

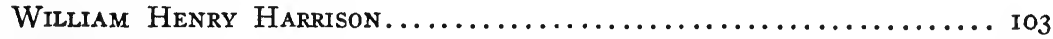

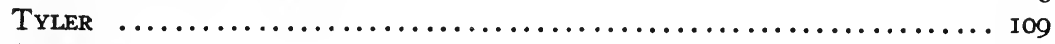

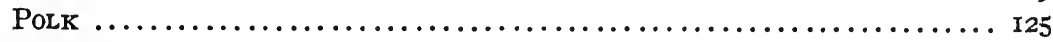

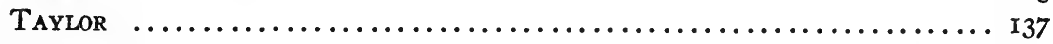

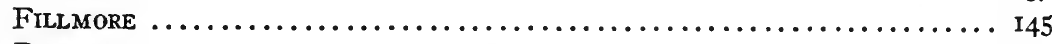

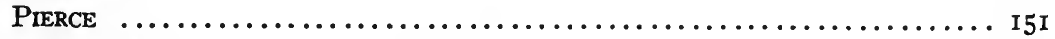

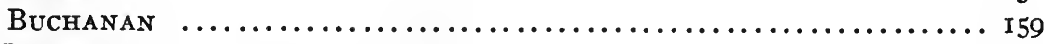

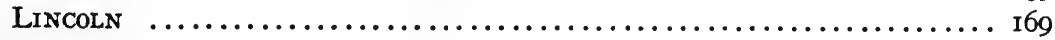

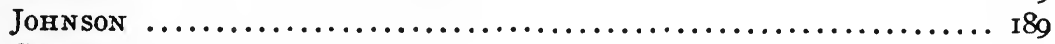

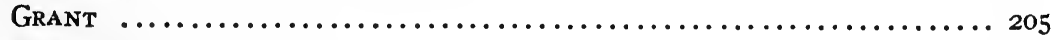

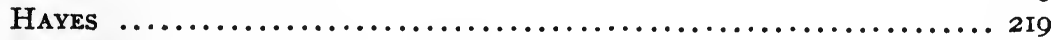

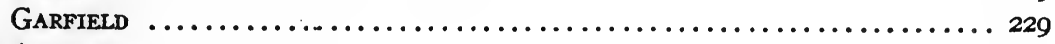

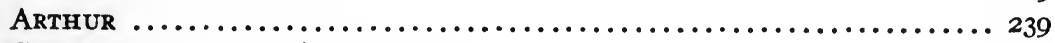

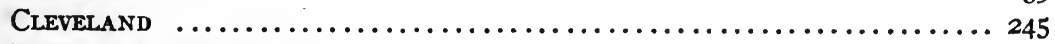

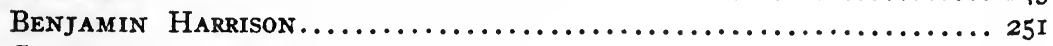

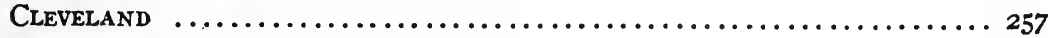

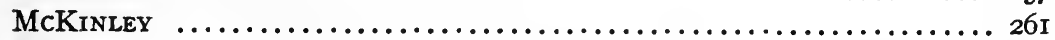

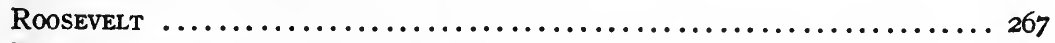

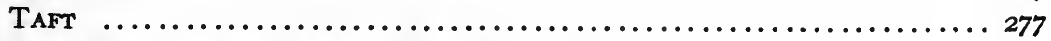

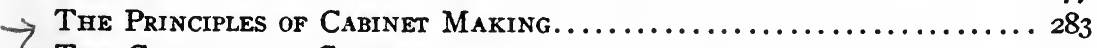

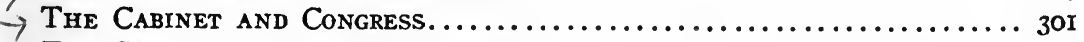

The Cabinet and the President......................... 3 I 3 


\section{THE ORIGIN OF THE CABINET.}

The use of the term Cabinet to denote a purely American institution is one of the misfortunes of political science. The Government of the United States drew upon the English nomenclature comparatively little. But this conspicuous instance has sufficed to make the English Ministry an almost inevitable point of departure for analyzing the functions of the President and his advisers. Writers have a fashion of seeking for resemblances that do not exist. And then they resort to negative and consequently disparaging definitions. The present study will try to determine what the American Cabinet is by bringing together the important facts of its own history, and attempting very little reference to English or Continental models.

We cannot ignore, however, the general background supplied by the political heritage that a group of English Colonies brought to the Government into which they entered as independent States. The Colonial charters were wont to provide for Governors and Councils, or Governors and Assistants; wherein the Privy Council appears in American Government from its beginnings. In the mingling of executive and legislative functions, these associates of the Governor combined, as a rule, the two characters of Council and Upper House. The ordinary Colonial Executive, therefore, was as though the President of the United States should sit in consultation with the Senate, except for the size of the latter body.

These Privy Councils of the original Governments survived the transition from Colony to State, though in various forms and under differing styles. The transitional Constitutions, laying hold of a different classification of governmental organs and functions, than had prevailed before, introduced the separation of Executive, Legislature and Judiciary. But this was not carried out so consistently as to break up all personal connection between Senates and Councils. On this point, a very few Constitutions retained the old arrangement, or modified it by providing for a smaller Council composed of specially chosen members of the Legislature; others were silent about 
the matter; while a substantial group definitely stipulated that a member of the Council should not at the same time be a member of the Legislature. These Councils in the early States had no exofficio connection with the administrative offices. Neither was their appointment by the Governor the vogue.

The root of the American Cabinet that is found in the Executive Departments naturally put forth its first substantial growth in American soil during the Revolutionary period.' A General Post Office had been established among the Colonies; but the Departments of War, Finance, and Foreign Affairs grew out of the exigencies of the struggle for independence. These establishments passed through the three forms of Committees of the Continental Congress, sometimes drawing members from outside, Boards, and finally, Departments with single Heads. This was a time when French examples were engaging the attention of some American publicists. And, when single Department Heads were agitated as the corrective for the divided responsibility and shifting membership of the Boards, the new feature was, to some extent, the substitution of French for English practice. Thus Alexander Hamilton wrote, in 1780: "Congress should instantly appoint the following great officers of State, a Secretary for Foreign Affairs, a President of War, a President of Marine, a Financier, a President of Trade. These officers should have nearly the same powers and functions as those in France analogous to them; and each should be chief in his own department; with subordinate boards composed of assistants, clerks, etc., to execute his orders." 2 Acting upon suggestions of the kind, Congress created the office of Secretary of Foreign Affairs, by a resolution passed January 10, I78r. And, in like manner, it provided, on February 7 , for a Superintendent of Finance, a Secretary of War, and a Secretary of Marine. The designation, Superintendent of Finance, was an appropriation of a French title of office, defunct at the time."

The Departments were not more vigorous than other branches of

${ }^{1}$ Jameson, Essays in the Constitutional History of the United States: J. C. Guggenheimer, The Development of the Executive Departments, 148-16e. 2 Works of Hamilton, (J. C. Hamilton ed.) I, I58-159, Hamilton to James Duane. Also contemporary letters to Robert Morris and Isaac Sears.

- American Historical Review, X, 565: Henry Barrett Learned, Origin o; Title Superintendent of Finance. 
the General Government during the period of the Confederation. A year elapsed before the Board of War gave way to a single head. Then, General Benjamin Lincoln served as Secretary two years, a chief clerk supplied a year's vacancy, and finally, General Henry Knox assumed the office. The Department of Finance reverted to a Board of Treasury, when Robert Morris was no longer available for superintendent. The Marine Office had no separate existence, being handed over to the Superintendent of Finance. The Department of Foreign Affairs was more steadily maintained than the others; it had for incumbents two such prominent men as Robert R. Livingston and John Jay. These early Department Heads were the appointees of the Congress. They were also the agents of that body; and enjoyed the privilege of personal intercourse with it, without being members. They never constituted a great Executive Committee or college.

However, the ex-officio relation of the great administrative officers to councils of state, and even ministries, was already a matter of conscious practice in the English and some Continental Governments, having its beginnings, so far as the Mother Country was concerned back of the founding of the Colonies. And the plan was not likely to be ignored by the framers of the Constitution of the United States. The Federal Convention had the question of a Privy Council before it in several forms. About June 4, in a discussion in which James Wilson and Roger Sherman were the principals, the subject came up, as a part of the question of a single or plural Executive." Wilson observed that all of the thirteen States, though they agreed in scarcely anything else, placed a single magistrate at the head of the Government. Sherman interposed to the effect that in all of the States there was a council of advice without which the chief magistrate could not act, and that this would seem to be a necessity, in order to make the new arrangement acceptable to the people. "Even in Great Britain," he said, "the King has a Council, and, though he appoints it himself, its advice has its weight with him, and attracts the confidence of the people." The question was then put to Wilson, whether he intended to include a Council, to which he replied that he did not, because such a body served more often to cover than to prevent malpractices.

-Elliot's Debates, ed. I845, I, 150, 151. 
Much later in the deliberations, the subject came up for fuller discussion. August $18^{\circ}$ Oliver Ellsworth remarked that a council had not yet been provided for the President, and that it ought to be done. In his opinion, such a body should be made up of the President of the Senate, the Chief Justice of the Supreme Court, and the Ministers for the Departments of Foreign and Domestic Affairs, War, Finance, and Marine, as such might be established, and it should advise, but not conclude the President. Charles Pinckney threw out the suggestion that the President should be authorized to call for advice or not, as he might choose; since, if he were given an able council, he would be thwarted by it, and, if he had a weak one, he would use it to shelter himself.

Two days later, Gouverneur Morris, seconded by Charles Pinckney, introduced resolutions upon which definite action was taken." There should be a Council of State; its membership should consist of the Chief Justice of the Supreme Court, and the Heads of Departments or Secretaries, of which there should be five, to be appointed by the President and to hold office during his pleasure. The President should be authorized to submit any matter to the Council for discussion, and to require the written opinion of any one or more of its members. But he should be expected in all cases to use his own judgment, and either conform to such opinions or not, as he might think proper. Moreover, every member was to be held responsible for his opinion on the affairs relating to his particular Department.

Morris' plan was at once referred to the Committee of Detail, whose members were John Rutledge, Edmund Randolph, Nathaniel Gorham, Oliver Ellsworth, and James Wilson. August 22, the Committee reported a clause that increased the proposed membership by two officers: "The President of the United States shall have a Privy Council, which shall consist of the President of the Senate, the Speaker of the House of Representatives, the Chief Justice of the Supreme Court, and the principal officer in the respective Departments of Foreign Affairs, Domestic Affairs, War, Marine, and

${ }^{5}$ Elliot Debates, Ed. 1845, V, 442.

'Elliot Debates, Ed. I845, V, 446. 
Finance, as such departments of office shall from time to time to established; whose duty it shall be to advise him in matters, respecting the execution of his office, which he shall think proper to lay before them; but their advice shall not conclude him nor affect his responsibility for the measures which he shall adopt." "

It was the fate of this clause, however, to be one of those that the Convention, weary of its tedious sittings and overwhelmed with many questions, passed over to the Committee of States, that was appointed towards the end to digest the unfinished parts of the Constitution in draft. And in the hands of this Committee, the plan was rejected, although its virtual author, Gouverneur Morris, and another pronounced advocate, Roger Sherman, were members. In lieu of it, there were reported, September 4, two provisions, that have since become familiar as parts of the Federal Constitution. "The President, by and with the advice and consent of the Senate, shall appoint ambassadors, and other public ministers, judges of the Supreme Court, and all other officers of the United States, whose appointments are not herein provided for." And, "He may require the opinion, in writing, of the principal officer in each of the Executive Departments, upon any subject relating to the duties of their respective offices." 8 This merely recognized that the proposed single Executive would come into such relation to the Departments, as Congress had previously enjoyed. Making the proposed Upper Chamber a council of appointments is traceable to the example of the State of New York.

But another plan for a privy council, was now interjected by George Mason. With a zeal which declared that to reject a council to the President was to try an experiment upon which the most despotic government had never ventured, since even the Grand Seignior had his divan, the distinguished Virginian introduced the motion, "That it be an instruction to the Committee of the States to prepare a clause or clauses for establishing an Executive council, to consist of six members, two from the Eastern, two from the Middle, and two from

${ }^{3}$ Elliot Debates, Ed. 1845, V, 462.

${ }^{8}$ Elliot Debates, Ed. 1845, V, 507.

${ }^{\circ}$ Constitution of New York, I777, Article XXIII. 
the Southern States, with a rotation and duration of office similar to that in the Senate, such council to be appointed by the Legislature of the State. ${ }^{10}$ Such suggestion of Oriental despotism seems for a moment to have reduced the misgivings about an Executive council to mere prejudice against the plan for its personal union with the Departments and its appointment by the Chief Executive. At any rate, the proposition to provide for a privy council after the fashion of those in the States found distinguished support. Franklin seconded Mason's motion, remarking that a council would not only be a check upon a bad President, but a relief to a good one. And Madison spoke in favor of reinstructing the committee, being himself a member of it. But Gouverneur Morris now dissented, saying that the question of a council had been considered by the committee, and that it was decided that the President would persuade such a board to concur in his wrong measures, and so acquire protection for them. This was decisive; for the motion to reinstruct was defeated by vote of eight States to three. The provision that the President should have power to call for the opinions of the Heads of Departments in writing was then adopted, only one State dissenting. The clause constituting the Senate a council to the President on the two subjects of appointments and treaties had been adopted earlier."

Thus the vague fear that a privy council would make the Executive the more formidable was allowed to have its way, so far as a Constitutional provision was concerned. But far-seeing minds were not unobservant of the fact that the way was left open for such a body to be evolved. The point was made once or twice, by Rutledge, chairman of the committee which reported favorably on the Gouverneur Morris scheme, that the President could advise with the high officers of State voluntarily. ${ }^{12}$ Of Hamilton's views no intimation was given beyond what may have lurked in the resolution that he introduced, June 18, that the Chief Executive should have the sole appointment of the heads or chief officers of the Departments of Finance, War, and Foreign Affairs. ${ }^{13}$ But Hamilton foresaw a great

${ }^{10}$ Elliot Debates, Ed. 1845, V, 522, 525.

${ }^{11}$ Elliot Debates, Ed. 1845, V, 526.

${ }^{12}$ Elliot Debates, Ed. 1845, V, 349, 442, 446.

is Elliot Debates, Ed. I845, V, 205. 
place for those chief officers. George Mason, with a Virginian's faith in Privy Councils, combined with suspicion of the New Yorker's Senatorial Council of Appointments, and hatred of English Cahinets, pointed out the lines of least resistance, and declared it a certainty that they would lead to ruin. The President had no Constitutional council, a thing unknown in any safe and regular government. Being unsupported by proper information and advice, he would be directed by minions and favorites, or he would become a tool of the Senate; or a council of state would grow out of the principal officers of the great departments, the worst and most dangerous of all ingredients for such a council in a free country.

It was true that the Constitution had fixed two centres from which the development of a privy council might proceed. And one of these was the Senate. With the new Government inaugurated, the President made a series of attempts to utilize the provision for advice about appointments and treaties. ${ }^{14}$ The most notable example is Washington's attendance, accompanied by General Knox, as Secretary of War, upon the Senate, for consultation on a negotiation with the Indians. But he found that body gauche and even unwilling, when its advisory powers were called into play. For more men apprehended the aggrandizement of the Presidency and the Departments than caught the vision of great consultative powers for the Upper Chamber. The result was that previous consultation was promptly eliminated both from appointment making and treaty making ; and the evolution of a Privy Council from the Senate was thereby precluded.

The other nucleus was afforded by the Departments. Still earlier than his attempt to frame a treaty face to face with twenty-two unresponsive Senators, Washington had exercised his Constitutional power to call upon the principal officers in the Departments for written opinions about subjects relating to their respective offices, by issuing a circular letter, addressed to the Secretary of Foreign Affairs, the Secretary of War, the Board of Treasury, and the Postmaster-General, all being appointees of the old Congress, holding

${ }^{14}$ Proceedings of the American Political Science Association, II, I28: Mary L. Hinsdale, The Cabinet and Congress. 
office by continuation under the new Government. ${ }^{15}$ Then came the great series of statutes that placed the Departments upon a new footing, as contemplated by the Constitution. The Act to establish the Department of Foreign Affairs was passed July 27, 1789; and September 15, the Supplementary Act, adding certain internal duties, and changing the name to Department of State. The War Department was established by Act of August 7. The Treasury was delayed almost a month longer, until September 2.

(There were certain differences of expression between the Treasury Act and the others, which were the subject of extended debate at the time, and were reserved for more momentous controversy forty years afterwards. The State and War establishments were styled, Executive Departments, while that of Finance was called, Department of Treasury. The Secretaries of State and War, it was ordered, should "perform and execute such duties as shall from time to time be enjoined on or entrusted to them by the President of the United States." The Secretary of the Treasury, on the other hand, was to discharge a series of functions that were enumerated by statute, and more generally, "to perform all such services relative to the finances, as he shall be directed to perform," the law being silent as to whether President or Congress should give the directions. Furthermore, the Secretary of the Treasury was formally authorized " to make report and give information to either branch of the Legislature, in person or in writing, as he may be required." So far the Treasury preserved much of its position under the old Government. However, the Heads of all the Departments alike were to be appointed by the President with the advice and consent of the Senate, and all were removable by the President alone. ${ }^{10}$

(The office of Attorney-General was created by the Act to establish the Judicial Courts of the United States, passed September 24. Its functions were to prosecute in the Supreme Court all suits in which the United States was concerned, and to serve as counsel on questions of law to the President and the Heads of Departments. ${ }^{17}$

\footnotetext{
${ }^{16}$ Writings of Washington, Sparks ed., X, II, 12 (with Footnote).

${ }^{16}$ Statutes at Large, I, 28, 49, 65.

${ }^{17}$ Statutes at Large, I, 93.
} 
The final and most essential action in the formation of the Cabinet is the institution by the President, without authority of law, of a college of advisers made up of the three Department Heads and the Attorney-General. This step presents a problem in the setting apart of those particular officers from certain others who were more or less obvious candidates for place in the President's councils.

A year had elapsed from the inauguration of the Government, before the Secretaries and Attorney-General were fully established in their offices. Alexander Hamilton, of New York, and Henry Knox, of Massachusetts, officially appointed to the Treasury and War Departments, on September II and I2, had been in virtual possession from the first. Hamilton, though he was technically but a by-stander, had assisted at the creation of his prospective Department, by sufferance of the President and Congress. The appointments were completed within a couple of weeks. But it was several months, before Edmund Randolph, the Attorney-General, arrived from Virginia. And Thomas Jefferson assumed the State Department so late as March, I790, delaying for a visit to his Virginia estates, after he had quitted his diplomatic post at Paris. In the early consultations, these officers are far from equally conspicuous. It is only in Cabinet polls that the President's official advisers ever are equal. And during this preliminary season, when consultations are recorded in written opinions only, the Secretary of War and the AttorneyGeneral are not strongly in evidence. General Knox' inferior ability in the writing of state papers probably explains the case so far as he is concerned.

Still further, a coterie of informal advisers, made up of Madison and Jay, and sometimes Adams, had been in the President's councils during the preceding year. ${ }^{18}$ And with the Departments and the Judiciary organized, the two groups become intermixed. Irregular consultations with Congressional leaders, and perhaps with the Chief Justice and Vice-President, are common to all Presidents. They arise from both official and personal reasons. But with the Cabinet in a nascent condition, we would discover what principle determined the separation. And we cannot forbear to notice that if we substi-

${ }^{18}$ Writings of Washington, X, Appendices II, IV. 
tute the figure of Madison, the leader of the House of Representatives, for Muehlenburg the Speaker, the entire group corresponds exceedingly well with the Privy Council that had been formally recommended by Committee to the Federal Convention. If, however, we would determine the principle upon which the line was drawn between Cabinet and extra-Cabinet consultations, we must examine a long series of more or less petty occurrences.

A few weeks after Jefferson's arrival at New York, Washington wrote to Lafayette: "Many of your old acquaintances are associated with me in the administration of the Government. By having Mr. Jefferson at the head of the Department of State, Mr. Jay of the Judiciary, Hamilton of the Treasury, and Knox of that of War, I find myself supported by able coadjutors who harmonize extremely well together." $\mathrm{He}$ here includes the Chief Justice and omits the Attorney-General, where a later President would have called the names of his Cabinet.

August 27, 1790, the President, by circular letter, called for written opinions on the following questions: "What should be the answer of the Executive of the United States to Lord Dorchester, in case he should apply for permission to march troops through the territory of the said States from Detroit to the Mississippi?" And, "What notice ought to be taken of the measure, if it should be undertaken without leave, which is the most probable proceeding of the two?" On this occasion, the three Secretaries, the Chief Justice, and the Vice-President were called upon for advice, but not the Attorney-General. ${ }^{10}$

In preparing the Annual Address to Congress that was delivered December 8, 1790, the President consulted the three Secretaries and

${ }^{10}$ The Editors of Washington's Works make the statement that the circular letter was addressed to "the several members of the Cabinet" and to the Vice-President and the Chief Justice in addition-Writings of Washington, Sparks ed., X, II2, Footnote; Ford ed., XI, 497, Footnote-. But the Letter Books give no sign that the Attorney-General was asked for an opinion. They do indicate, however, that Randolph was on one of his absences from the seat of Government-Letter Book, I790, 1, 2, 3, Washington to Randolph, August 25. 
the Chief Justice, and apparently left out the Attorney-General." Some of the earlier Addresses, it is attested, were submitted for criticism to Madison. ${ }^{21}$

The famous consultation on the question whether the Act to Incorporate the Subscribers to the Bank of the United States was constitutional (February 15-25, 179I) brings the Attorney-General into prominence. If the accepted tradition be correct, the AttorneyGeneral and each of the three Secretaries were called upon for written opinions, and the Cabinet comes into view differentiated. But there is a negative evidence that the Secretary of War was overlooked on this occasion. According to Washington's own statement, he had at first called upon the Attorney-General, in whose line the matter seemed more particularly to be, for his official examination and opinion. The Attorney-General's report being that the Constitution did not warrant the Act, he then applied to the Secretary of State for his sentiments upon the subject. These being found to coincide with the Attorney-General's, he required an opinion of the Secretary of the Treasury. The Secretary of War, he does not mention. ${ }^{23}$ Neither do any other contemporary, documents make reference to that officer. ${ }^{23}$ We suspect that such a great Constitutional question was too alien to Knox's talents for him to be called upon. It does not appear that he was absent from the seat of Government. Howbeit, the consultation has an extraneous figure in the person of Madison, who prepared for the President a draft of a veto message. ${ }^{24}$

${ }^{20}$ Writings of Washington, Sparks ed., X, I16, Washington to Hamilton, October 10; also II9, Washington to Knox, November 2; Writings of Jefferson, Ford ed., V, 257; Correspondence and Public Papers of John Jay, III, 409.

${ }^{21}$ Hamilton, History of the Republic, IV, 520, Hamilton to Carrington, May 26, 1792.

Washington's Letter Book, Treasury Department, 1790, I792; Works of Alexander Hamilton, J. C. Hamilton ed., I85I, IV, I03.

${ }^{23}$ Clarke and Hall, Legislative and Documentary History of the First Bank of the United States. 36 et seq.

${ }^{2}$ Writings of James Madison, Hunt ed., VI, 42. The accepted tradition seems to have been established by Marshall, who uses the following words: "The Cabinet was divided upon it (the Bank)... The advice of each 
The next pertinent event is a rudimentary Cabinet meeting, rudimentary in that it lacked the essential figure of the President, but included the Vice-President. The circumstances were that Washington, on setting out for a two weeks' tour of the South, addressed a letter, April 4, I79I, to the three Secretaries, saying that they should meet together for consultation, if any important business arose during his absence, and that the Vice-President should be included in their councils, if he had not already left the seat of Government. Neither the Attorney-General nor the Chief Justice was mentioned in the order; but Jefferson, who summoned a meeting, included Randolph with the others. ${ }^{25}$

In I792, the Cabinet becomes better differentiated. In April, the three Secretaries and the Attorney-General each submittd an opinion on the constitutionality of an Act for the Apportionment of Representatives, this being the occasion of the first veto. ${ }^{26}$ On August I5, the President, while enjoying his annual vacation at Mt. Vernon, wrote to the Secretary of War regarding certain Indian despatches, and requested that the Secretary of the Treasury should also consider them, observing that he should also have included the Secretary of State, had the latter officer been at Philadelphia. In a communication of four days later, he added that the Attorney-General should also be called on to aid with his opinions. ${ }^{27}$ In September there appears 10 have been a written consultation between the President and each of the four chosen officers regarding the Executive Proclamation, issued on the I5th of that month in consequence of the violation of the

Minister with his reasoning in support of it was required in writing"-Life of Washington, V, 345-. But neither Marshall nor any other early writer states what was Knox's opinion. Hildreth seems to be the first of those that venture to be more definite: "The President required the written opinions of the members of his Cabinet as to its (the Bank's) constitutionality. Hamilton, supported by Knox, was strong in the affirmative; Jefferson and Randolph took the other side-the first instance, it would seem, of an important difference of opinion in the Cabinet"-History of the United States, IV, 263.

${ }^{25}$ Writings of Washington, Sparks ed., X, 157; Writings of Jefferson, Ford ed., I, I65.

${ }^{26}$ Works of Hamilton, J. C., Hamilton ed., I851, IV, I96-215

${ }^{27}$ Writings of Washington, Sparks ed., X, 266-275. 
Excise Law. ${ }^{28}$ Furthermore, each was called upon for both special and general suggestions concerning the Annual Address to Congress that was delivered December 8, $1792 .^{29}$

Meanwhile, a fuller collegiate character was being added by an occasional Cabinet meeting. Presumably, these were in the first place informal; and it is pleasant to think that they were facilitated by the personal ties between Washington and his official household. Between him and Jefferson, there had hitherto been only a formal acquaintance, but the style of their association as President and Secretary was friendly. Randolph he had known as military aide, neighbor, and business adviser. Towards Knox he felt the bond of comradeship in the Revolutionary War very strongly. And to Hamilton, he was as deeply attached as he was to Lafayette. Furthermore, three of this group of five were Virginians, two of whom had been Governors of their State; whence it is highly probable that the collegiate Executive of the Old Dominion put its stamp upon the National councils. ${ }^{30}$ Cabinet meetings of 1792, and perhaps I79I, are recorded, rather vaguely, it is true, in Jefferson's Anas. But with the opening of 1793 , they are attested by Washington and Hamilton also, and formal summonses appear. ${ }^{\text {at }}$

${ }^{28}$ Writings of Washington, Sparks ed., X, 296.

${ }^{20}$ Writings of Washington, Sparks ed., X, 282--285 (with Footnote), 289.

${ }^{30}$ Constitution of Virginia, 1776.

${ }^{31}$ March II, 1792, Jefferson writes, speaking of the latter part of November, I79r, "Hamilton then proposed to the President at one of our meetings" etc.; and in the same entry, he refers to "one of our consultations" held in December of that year. (2) March 9, he notes for the day "a consultation at —, present H. K. \& J. (3) March 3I, he records "A meeting at the P's, present Th. J., A. H., H. K. \& E. R. "the question being whether the Executive should comply with the call of a Committee of the House of Representatives upon the Secretary of War, for papers relating to General St. Clair's expedition in the Northwest. April 12, he says "Met again at P's on same subject" (4) October 3r, a propos of the Spanish interference with the execution of the treaty between the United States and the Creeks, he says "he (the President) desired a consultation of Hamilton, Knox, E. R., and myself on these points." This consultation which Jefferson records in very definite terms, seems to be one, or one of a series, that John C. Hamilton, in his Republic denies ever to have occurred, V, I21. (5) December Io, the Anas says, "Present: A. H., General Knox, E. R. \& Th. J. at the 
But the decisive hours for the coherence of the Cabinet were in the months of panic, produced by the mission of the French Minister Genet. The most tangible mark of this is the closer association of the Attorney-General with the rest of the group. Randolph's aptitude for foreign affairs now made him a real force in the Executive Councils; while it so happened that the division which had existed since the Bank consultation gave to him the balance of power in the Cabinet polls to which the President now resorted. ${ }^{32}$ It was to Randolph, rather than the Attorney-General, that the increased importance belonged; nevertheless, the office enjoyed a better assured place thereafter. Furthermore, the whole Cabinet felt the cementing influence of assembling frequently. On April I9, occurred one of the most momentous Cabinet meetings of American history, the purpose being to arrange a policy of neutrality on the basis of a schedule of questions regarding the treaties with France, which the President had submitted on the I8th, by circular letter. ${ }^{33}$ And throughout the summer and autumn of I793, there were very frequent, often daily sessions, with the interruption of the President's vacation at Mt. Vernon. Jefferson marked this season as the real beginning of assembled consultation; for he wrote, seventeen years afterwards, that it had been Washington's practice to confer with his advisers separately, until the affairs of England and France, which threatened to embroil the United States, rendered discussion desirable. ${ }^{\text {*4 }}$

The President also attempted, at this crisis, to attach advisory functions to the highest Judicial authority. Some of the State Con-

President's the subject being a proposed Indian treaty "-Writings of Jefferson, Ford ed., I, I79-210.

For a Cabinet meeting of February 25, 1793, see Washington, Sparks ed., X, 317; Hamilton, J. C. Hamilton ed., IV, 340; Jefferson, Ford ed., I, 2 I8.

Also for the two meetings held to discuss the style of the President's second inauguration, Washington, Sparks ed., X, 322, Footnote; Hamilton, J. C. Hamilton ed., IV, 34I, 342.

Writings of Jefferson, Ford ed., I, 228; Anas, May 7, 1793: ibid. 270; Anas, November 28, 1793: ibid. V, 344; Jefferson to Madison, August II, 1793. ${ }^{33}$ Writings of Washington, Sparks ed., X, 337 ; also Appendix XV.

"Writings of Jefferson, Ford ed., IX, 273; Jefferson to Walter Jones, March 5 , 1810 . 
stitutions furnished a sort of precedent for such action..$^{35}$ We believe, however, that Washington simply lent himself in this matter to one of Hamilton's ideas. The President called upon the Justices of the Supreme Court, with a long list of questions, for an application of certain principles of international law to the treaties between the United States and France. But the extraordinary counsel idea was frustrated by the refusal of the Judges to answer the questions, on the ground that they lay outside of their province. ${ }^{28}$ On this occasion, an interesting conversation occurred between Jefferson and Randolph. The Secretary of State proposed to the Attorney-General that a bill be prepared to be submitted to Congress for the creation of a Board of Advice on International Law, and kindred subjects; to which the Attorney-General replied that he should propose annexing such Board to his own office, whereat the other dropped the subject. ${ }^{37}$ It would seem that Randolph's idea was virtually brought to pass, years afterwards, by the creation, inside of the Department of Justice, of Solicitors, or Assistant Attorneys-General to the State and other Departments.

Not only was a definite Council now set apart by the President's repeated summonses; but it began to be called by a particular name. Madison, Jefferson, and Randolph were among the first to refer to the President's Council as the Cabinet. Washington did not employ the term, his customary phrase being "the Secretaries and the Attorney-General," or, "the Heads of Departments and the Attorney-General," with such variations as "the confidential officers of Government," and "the gentlemen with whom I usually advise on these occasions." Neither did Hamilton adopt the name Cabinet, though he freely employed the term Ministers. In Congressional usage we have not noted the name earlier than the spring of 1806 , when the changes were rung on it in a caustic debate in which John Randolph figured. It appears in a Resolution of the House of Representatives, for the first time, we believe, so late as July 1867 . And it remained unknown to the statutes, until it appeared in the General Appropriation Act of February 26, 1907.

\footnotetext{
${ }^{35}$ Constitution of Massachusetts, I780; Constitution of Pennsylvania, 1776.

${ }^{3}$ Writings of Washington, Sparks ed., X, 360: also Apendix XVIII.

${ }^{37}$ Conway, Edmund Randolph, 186.
} 
It remains to formulate the principle by which the members of the Cabinet were set apart from other advisers to the President. Obviously the inner Council was built upon the plan that had been before the Federal Convention, having for its basis the administrative Departments, but including the chiefs of all the branches of the Government. How soon Washington drew a line in his own mind across the larger group, there is nothing to show ; the Cabinet meeting marks the visible separation. There is some slight ground for believing that in choosing his judicial adviser, he hesitated between the Chief Justice and the much humbler Attorney-General, who had not been named in the Convention. As for the rule by which the line was drawn,- - there can be no doubt that it was removability by the President, a conclusion that is borne out by the whole history of the Cabinet. 
President.

GEORGE WASHINGTON, Virginia.

ViCe-PRESIDENT.

JOHN ADAMS, Massachusetts.

April 30, 1789, to March 4, 1793.

Secretary of State.

Thomas Jefrerson, of Virginia, September 26, 1789.

Secretary of the Treasury.

Alexander Hamilton, of New York, September ir, I789.

Secretary of War.

HeNRY KNox, of Massachusetts, September 12, 1789.

Atrorney-General.

Edmund Randolph, of Virginia, September 26, 1789. 
President.

GEORGE WASHINGTON, Virginia.

Vice-President.

JOHN ADAMS, Massachusetts.

March 4, I793, to March 4, I797.

\section{SeCretary of State.}

ThOMAS JefFerson, of Virginia; continued from last Administration.

EDMUNd RANDoLPh, of Virginia, January 2, I794.

Timothy Pickering, of Pennsylvania (Secretary of War), ad interim, August 20, 1795 .

Timothy Pickering, of Pennsylvania, December io, 1795.

Secretary of the Treasury.

Alexander Hamilton, of New York; continued from last Administration. Oliver Wolcott, JR., of Connecticut, February 2, I795.

\section{SECRETARY OF WAR.}

Henry Knox, of Massachusetts; continued from last Administration. Timothy Pickering, of Pennsylvania, January 2, I795.

JAmes McHenry, of Maryland, January 27, 1796.

\section{Attorney-General.}

Edmund Randolph, of Virginia; continued from last Administration.

William Bradford, of Pennsylvania, January 27, 1794.

Charles Lee, of Virginia, December io, 1795. 


\section{WASHINGTON.}

The first Cabinets that Washington formed had two features which should command particular attention for the very reason that their unsuitability to the political genius of the new Nation was so quickly demonstrated. We refer, in the first place, to the bend that was momentarily given to the Executive by Hamilton. Though the great Secretary-Publicist bears a general reputation for political anglomania, the fund of comment upon his theories and purposes has been more fragmentary than exhaustive. Nor can we at present be more ambitious than to note his more striking utterances and practices.

In one of his Federalist Letters, Hamilton points to a radical difference between the English and American Executive as proof that a Constitutional Council to the President would bring bad results. The English Government had a permanent Chief Magistrate; his person was sacred: whence it had been convenient for the maxim to prevail that he was irresponsible. And the responsibility that could not reside in him, a Constitutional Council was the most eligible means of supplying. But under a republican Government, no such character appertained to the Chief Magistrate; he was himself a responsible officer: whence the addition of a Constitutional Council would vitiate, or at least seriously impair, in the American Executive, the very thing that it supplied to the British. ${ }^{1}$ In his practice, as in his writings, Hamilton never put any stress upon the collegiate Cabinet, though he conceived that the President must necessarily act through Ministers.

Especially did he conceive of the Head of the Treasury as a more exalted officer of state than earlier use of the title, Secretary, would signify. In the Federalist he forecast that the finances were to be put

\footnotetext{
${ }^{1}$ The Federalist, No. LXX.
} 
into the hands of a single statesman, who should be not merely an administrative officer, but the originator of all plans of revenue." On the vital question of separation of the great branches of government, Hamilton upheld the Constitutional arrangement as a security to the rights of the people. ${ }^{3}$ But the provision that officers of the Government shall not at the same time be members of the Legislature, left room, as he construed it, for personal communication with Congress by Department Heads, as practiced under the former Government. Indeed it would seem to have denied none of a member's active privileges except voting.

All these views the prospective Secretary was able to incorporate into the Treasury Act. It is true that a heated debate in the House resulted in a narrowing of the proposed authority to introduce plans for revenue, by withholding the privilege of making uncalled for reports." Still the head of the Department remained potentially a real Minister of Finance. Furthermore, the provision that the Secretary of the Treasury should make reports in person or in writing, as directed, seems by its very absence from the Acts creating the State and War Departments, to set apart the Minister of Finance as the organ of communication between the Executive and Congress. All in all, the Treasury was to be the very heart of the administration, not only the main artery through which the stream of Executive operations must pass, but also the seat of the propelling force.

For Hamilton's activities as Secretary of the Treasury, Department lines scarcely existed. He concerned himself with proposed commercial negotiations with England and France, and held conferences to that end with the Ministers of those Governments." Resisted by Jefferson with some success, he went so far as to order the revision of the foreign despatches when Randolph was Secretary." And he assumed the leading part in shaping Jay's mission to Eng-

${ }^{2}$ Federalist, No. XXXVI.

${ }^{3}$ Federalist, No. LI.

Annals of Congress, I, 616-631: Works of Fisher Ames, I, 56.

${ }^{5}$ Writings of Washington, Sparks ed., X, Appendix XIII; Jefferson to Washington, September 9, I792.

${ }^{6}$ Works of Hamilton, J. C. Hamilton ed., IV, 544. 
land. ${ }^{7}$ He concerned himself equally about the business of the Secretary of War, and found Knox comparatively tractable. His crowning act of assumption of responsibility occurred in the Whiskey Insurrection, when he accompanied the President on the expedition into Western Pennsylvania, in some such fashion as a chancellor attends his emperor in the field. This affair he made a pretense of bringing within the pale of his own Department, by urging that the insurrection was in resistance to the Excise Act, and that in such a Government as the American, it must have a good effect for the person who was understood to be the advisor or proposer of a measure that brought danger to his fellow citizens, to share in that danger himself. 8 Both of the other Secretaries seem to have countenanced this Chief Ministership to the extent of referring to the Treasury as an intermediary between their Departments and Congress, when money was desired. Thus Jefferson referred a proposed negotiation with the Barbary States to Hamilton, on the question, how great a douceur the Senate would agree to. And a similar situation is found in the communication to the House of Representatives by Hamilton of what was really a request from Knox for the rehabilitation of West Point. ${ }^{10}$ Hamilton also assumed authority to call upon the Chief Justice to prepare a draft of a Proclamation of Neutrality in the hour of Minister Genet's arrival. ${ }^{11}$ And it was at his instance that the President turned to the Supreme Bench for extraordinary counsel. Of his legal responsibility to the President, the Secretary-Minister seems to have been duly sensible. It is true that he addressed to the Speaker of the House of Representatives a notice of his intention to retire; but this seems to be traceable entirely to the fact that his Department was undergoing investigation at the time. ${ }^{12}$

\section{${ }^{7} \mathrm{~J}$. C. Hamilton, History of the Republic, IV, 544-554, 567.}

${ }^{8}$ Works of Hamilton, J. C. Hamilton ed., V, 30; Hamilton to Washington, September 19, I794.

${ }^{2}$ Works of Hamilton, J. C. Hamilton ed., IV, 215.

${ }^{10}$ Works of Hamilton, III, 82.

${ }^{11}$ Correspondence and Public Papers of John Jay, III, 474-477.

${ }^{12} \mathrm{~J}$. C. Hamilton, History of the Republic, IV, 136; Hamilton to Speaker of House of Representatives, December I, 1794. 
Such assumption of authority was not slow to incur the charge of Ministerial ambition. Edmund Pendleton, a looker-on in Virginia, plainly asserted, writing to Washington, that the Secretary of the Treasury had " made the system of the British Ministry the model of his conduct as assumed American primate." ${ }^{13}$ The question arises whether Hamilton's conception of the Executive does not better resemble the Elizabethan than any Georgian model. But, whatever his theory was, his practice looked to a chief ministership, which, if realized, must have circumscribed the development of the Presidency, and have given a very different trend to American practice in legislation.

The other marked feature of the early Executive that quickly proved impracticable was the representation in the Cabinet of different political parties. This practice was attendant upon the idea that the President was superior to party. Such conception was soon found to be totally incongruous with having the highest office in a republican government elective, though it was justified by the working of the machinery for choosing Presidents in 1789 and again in 1793. Furthermore, Washington himself found mixed councils a sore grievance, and settled down to a party Cabinet for the last two years of his administration. Doubtless the quarrels between Jefferson and Hamilton gave him a turn towards this decision. But a more immediate incentive was his grief and rage at Randolph's faithlessness towards the administration, while he was Secretary of State.

The theory of a balanced Executive has been overdone, when it has been used to explain the original Cabinet appointments. And some of the familiar statements about it commit the double anachronism of assuming, both, that parties were differentiated, and that a clear notion of the Cabinet existed, when those appointments were made. It seems a trustworthy tradition that Washington fixed upon Hamilton for the Treasury, Jay and Robert Morris advising it, for the paramount reason of his ability to organize the finances. And regarding the selection of Jefferson and Randolph, there are letters by Washington that speak of fitness and availability, but are silent

${ }^{13}$ Writings of Washington, Sparks ed., X, 37o, Footnote. 
about those gentlemen's views of the Constitution. But a clear purpose to represent widely divergent political sentiments in the Executive appears in the President's persistent efforts to retain the two great leaders after distinctions of Federalist and Republican had brought discord into the administration.

Everybody knows that the two Secretaries had common ground enough at the outset to enter into a bargain, whereby the Virginian gave his influence to such a centralizing measure as the assumption of the State debts, in return for a concession to Southern pride by the New Yorker, in the matter of locating the National Capital. Jefferson's first note of opposition to Hamilton was sounded in a letter written in January, I79I, when the Bank Act was pending. He herein refers to the need of putting the agricultural interest above that of the stock jobbers; and goes on to say that there is a sect in the Government, which is opposed to the French, and which believes that the English Constitution contains whatever is perfect in human institutions. At about the same date, the correspondence between the two Secretaries loses its personal flavor, and becomes strictly official. By the following year, the breach had so widened that the hostile Ministers fought a battle in the newspapers, Jefferson attacking Hamilton through the columns of Freneau's National Gazette, and Hamilton retaliating through Fenno's Gazette of the United States. The situation demanded the interposition of the President ; and Washington addressed a long letter to each, in which he enjoined "mutual forbearance" and "temporizing yieldings," and lamented that the young government was endangered by animosities between those who should be its protectors. ${ }^{14}$ In I793, the Cabinet table became the scene of such quarrels that Jefferson afterwards wrote: "Hamilton and I were daily pitted in the Cabinet like two cocks." 15

As the President's first term of office neared its close, the Secretary of State talked of resignation; but his chief dissuaded him. And on one occasion, Washington is represented as distinctly saying

${ }^{14}$ Writings of Washington, Sparks ed., X, Appendix XIII.

${ }^{15}$ Writings of Jefferson, Ford ed., X, 273; Jefferson to Walter Jones, March 5, 1810. 
that it was important to preserve the check of Jefferson's opinions in the administration, in order to keep things in their proper channel. ${ }^{16}$

Viewed through the atmosphere of decades of party history, the position of the Secretary of State in I793 appears too incongruous to be maintained. The policy of the Government was strict neutrality between France and England. The Foreign Secretary, by his political affiliations and personal ties, sympathized with the French. At the same time, his antagonist in the Treasury sympathized with the English. Perhaps Washington found the shades of feeling and opinion in this crisis no more divergent than Lincoln felt them to be in the Civil War. But Jefferson's position is unique in American history, in that he was himself the organ of a policy, to which he was emphatically opposed. Herein lies the reason why his secretaryship is the least distinguished chapter in his career. The rule of political balance made it impracticable to institute that other rule, very commonly observed in later times, of paying deference in a Cabinet question to the Secretary whose Department is most closely touched. Washington reached his decisions during this season by Cabinet polls, much of the time deciding according to the majority. Nevertheless, the State Department held down the Treasury. And Jefferson was too derogatory of his own influence, when he declared four years afterwards, apropos of the rumor that President Adams was going to summon the Vice-President to the Cabinet councils, that he could not wish to see the scenes of '93 revived, and to descend daily into the arena like a gladiator to suffer martyrdom in every conflict.

Jefferson's retirement at the close of this year was followed by the promotion of Randolph to the State Department. A number of men had previously been considered, both Republicans and Federalists. ${ }^{17}$

16 Writings of Jefferson, Ford ed., I, 204.

${ }^{17}$ Jefferson states that the following men were mentioned between the President and himself: Madison, who would have been the President's first choice, but was unwilling to accept office under the Executive, Chief Justice Jay, who preferred the post that he already had, William Smith and Edward Rutledge, both of South Carolina, Judge Thomas Johnson, of Maryland, Chancellor R. R. Livingston, of New York, and finally Edmund Randolph, the Attorney-General. (Writings of Jefferson, Ford ed., I, 257; Anas, August 6, 1793.) 
The resulting vacancy in the office of Attorney-General was filled by the appointment of William Bradford, a young lawyer from Pennsylvania, who was presumably Hamilton's choice. A year later, further reconstruction was necessitated by the retirement of both Hamilton and Knox. Hamilton named his own successor, Oliver Wolcott, previously Comptroller of the Treasury. A Secretary of War was found in Timothy Pickering, who had at the time a residence in Pennsylvania. Mr. Pickering had been a member of the old Board of Treasury, and had latterly become Postmaster-General. And from the War Office, he went to the State Department. Whence he bears the commonplace distinction of the most varied experience in the Departments that any man has had. ${ }^{18}$

In the State Department, Randolph showed himself a consistent Republican, with his colleagues all Federalists of one shade or another. He was at variance with the administration, both on the suppression of the Whiskey Insurrection, and the ratification of Jay's Treaty with England. But there was no plan to put an end to the anomaly, until the Secretary of State was discovered in an intrigue with the French Minister. In his isolated position, Randolph allowed himself to become a party to one of those cases of diplomatic interference that held the Government, during its first quarter of a century, in a sort of wardship to France and England. At the time of the Whiskey Insurrection, he fell to communicating the secrets of the administration to Minister Fauchet, who made them the subject of despatches to his own Government, which not only based their information upon "the precious confessions of Mr. Randolph," but alluded to transactions that had involved "some thousands of dollars." The papers were intercepted by a British war vessel, passed into the hands of the British Minister to the United States,

${ }^{18}$ The War Department was first offered to General Charles Cotesworth Pinckney, who had declined an Associatc-Justiceship in I79I, and was regarded as one of the most prominent men in the country that did not desire office under the National Government. Though expressing a preference for the War Department over all other offices, General Pinckney declined the offer, chiefly on personal grounds. (Writings of Washington, Sparks ed., $\mathrm{X}, 391,392$, with Footnote.) 
and were communicated to the Secretary of the Treasury. The President, returning from his vacation retirement to hold a Cabinet council on the acceptance of Jay's Treaty, confronted his Secretary of State with the suspicious disclosures, and one day later, that officer put his resignation into the hands of his chief. The affair stirred a great storm of emotions in Washington's breast. ${ }^{19}$

The ensuing reconstruction of the Cabinet furnishes, by its extreme difficulty, one of the most striking proofs of the unpopularity that the Government sustained by the ratification of the Treaty of I795 with England. But the most significant fact is the President's decision that the representation of different political parties in the Executive was insupportable. He made a distinct declaration in a letter to his Secretary of War: "I shall not, while I have the honor to administer the Government, bring a man into office of consequence, knowingly, whose political tenets are adverse to the measures, which the General Government are pursuing ; for this, in my opinion, would be a sort of political suicide. That it would embarrass its movements is most certain." ${ }^{20}$ At leas.t one candidate that attracted the President's favorable consideration for the State Department, Edmund Pendleton of Virginia, was dropped, because Hamilton pointed out that he was leaning too much to the political doctrines of Jefferson and Madison. The vacancy was filled after a long interval by the promotion of the Secretary of War. ${ }^{21}$

The War Department was thus vacated, as was also the AttorneyGeneralship, Mr. Bradford having died in office. The former was accepted by James McHenry of Maryland, and the latter by Charles Lee, a young lawyer from Virginia. The Cabinet was now an entirely Federalist body. And the unanimity of party principles

${ }^{10}$ Upham, Life of Timothy Pickering, III, 225, 226.

${ }^{20}$ Writings of Washington, Sparks ed., XI, 74; Washington to Pickering, September 27, I795.

${ }^{21}$ The State Department was offered successively to Judge Thomas Johnson of Maryland, General Charles Cotesworth Pinckney of South Carolina, Associate-Justice William Patterson of New Jersey, and Patrick Henry of Virginia. (Writings of Washington, Sparks ed., XI, 78, 8r ; Washington to Edward Carrington and to Patrick Henry.) 
thus established immediately became the fundamental rule of forming an administration. ${ }^{22}$

${ }^{2}$ Before the War Office found an incumbent on this occasion, it was offered to Colonel Edward Carrington of Virginia, an intimate friend of Hamilton's, and to Governor John E. Howard of Maryland. (Writings of Washington, Sparks ed., XI, 78, 93, 106.)

The Attorney-Generalship was first offered to John Marshall, who had not yet held office under the National Government, and declined this post on the ground that it would too greatly interfere with his private practice. It was then offered to Colonel Innes, also of Virginia. (Writings of Washington, Sparks ed., XI, 62, with Footnote.) 
President.

JOHN ADAMS, Massachusetts.

VICE-PRESIDENT.

THOMAS JEFFERSON, Virginia.

March 4, I797, to March 4, I80I.

Secretary of State.

Timothy Pickering, of Pennsylvania; continued from last Administration.

Charles Lee, of Virginia (Attorney-General), ad interim, May I3, I80o. John Marshall, of Virginia, May I3, I800.

Secretary of the Treasury.

Oliver WolcotT, JR., of Connecticut; continued from last Administration. SAMuer Dexter, of Massachusetts, January I, I8or.

\section{SECRETARY OF WAR.}

James McHenry, of Maryland; continued from last Administration.

Benjamin Stoddert, of Maryland (Secretary of the Navy), ad interim, May 6, 1800.

Samuel DeXter, of Massachusetts, May I3, I80o.

Samuel Dexter, of Massachusetts (Secretary of the Treasury), ad interim, January I, r8or.

AtToRney-GeneraL.

Chardes LeE, of Virginia; continued from last Administration.

Secretary of the Navy.

Benjamin Stoddert, of Maryland, May 21, I798. 


\section{JOHN ADAMS.}

The administration of John Adams is signalized by the first testing of the authority of the President over his official advisors. The insubordination of the Secretaries was not a conscious attack upon the Chief Executive's office, but only a part of a quarrel between two factions of Federalists. And yet the controversy shows, in many of its details, that a comparatively humble place was reserved for the Presidency, when Washington retired from his peculiar office as sponsor for the Constitution. And Adams' resort to powers as yet unused was an important step towards fixing the relation between the two parts of the Executive.

The new President retained the Cabinet of his predecessor, though Secretary Wolcott is known to have offered his resignation. The existing procedure was also continued for a time. The President promptly called for written opinions on a schedule of questions concerning the state of diplomatic relations between the United States and France. ${ }^{1}$ In preparing the Address to Congress for the special session of 1797 , he requested suggestions that were not to be confined to departmental matters. Cabinet meetings were also continued.

The actual mastery, however, Adams had to dispute with Hamilton, in the extra-legal role of party chief. The political antagonism between the two had been manifest from the earliest presidential elections. And with Adams now elevated to that office, the party leader put aside the deference that Washington had commanded of him. At the same time he retained the influence over the Secretaries that he had gained as a sort of permanent Minister to the previous administration. Wolcott, in the Treasury, was his echo. Pickering, in the State Department, was more emboldened by a sense of long experience in Executive office, which indeed antedated the Pres-

${ }^{1}$ Gibbs, Administrations of Washington and Adams, I, 500. 
idency. Moreover, he was like President Adams himself, in being the victim of a pugnacious and stubborn disposition.

In such a delicate situation, Mr. Adams allowed concerted action between President and Department Heads to suffer for his absences from the Capital. Washington had been accustomed to spend about two months at Mt. Vernon, during the hot season. Indeed the important consultation over the acceptance of Jay's Treaty was conducted almost entirely by correspondence. And, when he was at the seat of Government, he sometimes authorized the Cabinet to deliberate without being himself present. But Washington, fortified by loyalty to his person, had no reason to fear cabals. Notwithstanding his different situation, Adams indulged himself in longer vacations. And, during one of the most critical periods in his term of office, the summer of I799, being detained by illness in his family, he was absent from the proper scene of his official duties between seven and eight months.

As the special session of I797 approached, the President's Constitutional relation to the subject of foreign affairs was made little account of, by former members of the Government. Fisher Ames, now retiring from the House of Representatives, wrote to Wolcott, urging that the three Secretaries should digest a plan of action, and be prompt to secure the cooperation of the Federalists in Congress. And Hamilton put a matured scheme for a special commission to France into the hands of certain Senators. ${ }^{3}$ The latter proceeding came to Adams' knowledge; and, when he published an account of his Cabinet quarrels years afterwards, he likened Hamilton to a physician, who undertook " to prescribe for a President, Senate, and House of Representatives, all desperately sick, and in a deplorable state of debility, without being called."

The strife between Adams and his Cabinet included three distinct controversies. The first was about the appointment of the Commissioners that were dispatched to France in 1797." The President

${ }^{2}$ Gibbs, Administrations of Washington and Adams, I, 499; Ames to Wolcott, April 27, 1797.

${ }^{3}$ Gibbs, Administrations of Washington and Adams, I, 463.

"Gibbs, Administrations of Washington and Adams, I, 463-470. 
earnestly desired to name Elbridge Gerry of Massachusetts as one of the number; and the suggestion that the Commission include one Republican with two Federalists was received with so much favor, that the names of both Madison and Vice-President Jefferson were proposed. But of Gerry, the Cabinet would not approve. The President accordingly nominated three Federalists, Charles Cotesworth Pinckney, the Minister lately rejected by the French Government, John Marshall of Virginia, and Francis Dana of Massachusetts. But Judge Dana declined to serve; whereupon Gerry was appointed in his stead. Thus the President yielded at first; but ultimately carried his point.

The second controversy arose about the ranking of the MajorGenerals in the provisional army created in $1798 .^{5}$ Washington had been appointed Lieutenant-General, with the understanding that he should have a share in the naming of the other officers. ${ }^{.}$Upon receipt of his commission, the Lieutenant-General transmitted a list of Major-Generals, which included Alexander Hamilton, Charles Cotesworth Pinckney, and Henry Knox, ranking in the order named. Displeased at the advancement of Hamilton over two officers who had been his superiors in the Revolutionary War, in which matter his objections had more than a personal basis, since Knox ultimately declined his commission, the President sought a means of preserving the old order. The appointments were made as arranged; but the commissions were so dated as to put Knox first, Pinckney second, and Hamilton third. Washington now interposed. Charging the President, in calm but forcible terms, with failure to carry out the agreement between them, he threatened to resign his own commission. And Adams was compelled to reverse the order of rank for the Major-Generals. ${ }^{7}$ Doubtless Washington was actuated by his old partiality. But the Secretaries were in his counsels. Picker-

${ }^{B}$ Gibbs, Administrations of Washington and Adams, II, 99-IO3.

- Writings of Washington, Sparks ed., XI, Appendix XI; Adams to McHenry, July 6, I798. Also Adams to Washington, July 7, I798.

'Writings of Washington, Sparks ed., XI, 304; Washington to Adams, September 23, I798: also Appendix XIV; Adams to Washington, October 9, 1798. 
ing had urged him to secure the placing of Hamilton at the head of the lis.t. ${ }^{8}$ And McHenry was believed to have had a hand in the arrangement, when he conveyed the Lieutenant-General's commission to Mt. Vernon. It was to the prestige of Washington's name that the President yielded; but, nevertheless, the Secretaries had a share in the triumph over him.

April 30, 1798, the Act was passed that established the Department of the Navy. Much difficulty attended the filling of the new Secretaryship. And Wolcott wrote four weeks after its creation, that the proper business of the new Department continued to be divided between the War Office and the Treasury, and was likely to remain so. Ex-Senator George Cabot of Massachusetts, a prominent member of the Hamilton faction, declined the office; and it was finally accepted by Benjamin Stoddert of Maryland, a man engaged in extensive mercantile pursuits.

The administration was next at cross purposes about the second attempt to resume diplomatic relations with France." June 21, I798, in a famous message to Congress, the President had disclaimed all intention of making another approach to the French Government, until certain assurances had been received from it. But, December 8, in his Annual Address, he moderated that tone, and acted contrary to the advice of the Cabinet in so doing. He furthermore, withheld his confidence from his official advisers, as his new policy shaped itself. February 18, 1799, without the previous knowledge of the Secretary of State, or any other of the Cabinet officers, he nominated as Minister Plenipotentiary to France, William Vans Murray. The proposed embassy being converted into a second commission, the names of Chief-Justice Oliver Ellsworth, and Governor William R. Davie of South Carolina were added. The President's appointments were confirmed in the face of active opposition from the Cabinet.

The Secretaries then proceeded to take advantage of the President's long absence to devise plans for defeating his policy. And they finally joined in a written demand that the Commission to

${ }^{8}$ Writings of Washington, Sparks ed., XI, Appendix XI, Pickering to Washington, July 6, I798.

'Gibbs, Administrations of Washington and Adams, II, I88-272. 
France be delayed. ${ }^{10}$ This brought the administration together again, the President meeting the Cabinet, October 15, at Trenton. Before Mr. Adams' arrival, Hamilton had been on the scene. The President refrained from declaring his own state of mind at the Cabinet meeting, for which he was afterwards accused of misleading his advisers. He discussed the proposed instructions with them, and a day later, issued to the Secretary of State and the Secretary of the Navy final orders for despatching the Commission. Thus in the last and most aggravated controversy of his administration, President Adams carried his point. He did not have a united Cabinet against him; for Stoddert, the newest of the Secretaries, had not staunchly supported his seniors, and Attorney-General Lee, finding the Commission favorably regarded by the Virginia Federalists, was of like mind.

Six months later, the President completed the demonstration of his supremacy in Executive affairs by hurling two of the Secretaries from office. Such a catastrophe was not unthought of by the Cabinet officers themselves, crude as their conceptions were of loyalty to the head of the Executive, and safeguarded as they believed themselves to be by the political situation. Pickering might well have been disquieted about his efforts to defeat the appointments. He has recorded, though as a reproach to Adams more than to himself, that in the promotion of Colonel Smith, the President's son-in-law, he remonstrated two or three times with his chief against the nomination, and finding himself unable to prevent it, he repaired to the corridor of the Senate to secure votes against its confirmation. And Adams charges that the Secretary of State had striven to head off his most important measures, working particularly against the appointments of Gerry, Smith, and Murray. ${ }^{1 i}$ Secretary Wolcott had exposed himself to the presidential wrath particularly by acting as the spokesman of the Cabinet in the affair of the Major-Generals. The Secretary of War expressed the opinion, however, writing to Washington after the departure of the Commission, that it was doubtful whether the President would remove any of the Cabinet; that he was highly displeased with Pickering and Wolcott, and somewhat so with

${ }^{10}$ Gibbs, Administrations of Washington and Adams, II, 270.

${ }^{11}$ Gibbs, Administrations of Washington and Adams, II, 350. 
McHenry himself; but that there were powerful personal reasons which forbade a rupture, especially at that moment. ${ }^{12}$ And the President did delay, until the election of the State Legislatures had shaped forces for the approaching presidential election. Early in May, I80o, he notified Secretaries Pickering and McHenry, that their resignations would be accepted. McHenry promptly complied; but Pickering expostulated. The President then sent an unvarnished order of dismissal. "Divers causes and considerations essential to the administration of the Government, in my judgment requiring a change in the Department of State, you are hereby discharged from any further services as Secretary of State." 13

In reconstructing the Cabinet, Adams found eminently respectable support. John Marshall, a member of the House of Representatives at the time, declined the War Department, but accepted the State portfolio. And Samuel Dexter, of Massachusetts, who was entering upon only the second year of a Senator's term, resigned his seat to become Secretary of War. But it was impossible to fill vacancies that arose the following winter, when a Republican administration was only a few weeks in the future. Secretary Wolcott, who had been spared, when his allies were removed, presumably because of the condition of the Treasury Department, and out of deference to his constituency, put the President to great embarrassment a few months later by an untimely resignation. Furthermore, the AttorneyGeneral's office was vacated by the designation of Mr. Lee to one of the newly created Circuit-Judgeships. A long list of appointees refused to enter an expiring administration; and the breaches had to be covered by ad interim service on the part of the other Cabinet officers. When Marshall was appointed Chief-Justice of the United States, Dexter, who had charge of both the Treasury and War Departments, was authorized to act as Secretary of State for the purpose of counter-signing the commission.

It is important to note that, while the Cabinet was humbled in this contest, it maintained a right to exist. The Secretaries were pre-

${ }^{12}$ Writings of Washington, Sparks ed., XI, Appendix XXI; McHenry to Washington, November I0, I799.

${ }^{13}$ Upham, Life of Timothy Pickering, III, 486. 
vented from overruling the President, and were thereby relegated to the under position in the Executive. But the storm of attendant discussion shows, making due allowance for the violence of faction, that public opinion demanded for them some sort of position. One of the most heated expressions, we quote from George Cabot of Massachusetts: "Must it not become a maxim, never to be violated, that the President shall be always accompanied by those whom he has selected to assist him in carrying on the Executive Government? If at any time, he is absent for the benefit of relaxation, let it be adhered to that he does no business, and gives no opinions. If some system like this is not established, there will be no order nor consistency in our affairs." A more significant, because more temperate, statement was made by Hamilton: "A President is not bound to conform to the advice of his Ministers. He is even under no positive injunction to ask or require it. But the Constitution presumes that he will consult them; and the genius of our Government and the public good recommend the practice." ${ }^{14}$ This sentiment had become firmly established at a very early date.

${ }^{14}$ Works of Hamilton, J. C. Hamilton ed., VII, 708; The Public Conduct and Character of John Adams, Esq., President of the United States. 


\section{President. THOMAS JEFFERSON, Virginia. \\ VICE-PRESIDENT. AARON BURR, New York.}

March 4, I801, to March 4, I805.

\section{Secretary of State.}

Levi Lincoln, of Massachusetts (Attorney-General), ad interim. March 4, I80I.

James Madison, of Virginia, March 5, i8or.

Secretary of the Treasury.

Samuel Dexter, of Massachusetts; continued from last Administration. Albert Gallatin, of Pennsylvania, May I4, I80I.

SeCretary of War.

Henry Dearborn, of Massachusetts, March 5, r8or.

\section{Attorney-General.}

Levi Lincoln, of Massachusetts, March 5, i80r.

SeCretary of the Navy.

Benjamin Stoddert, of Maryland; continued from last Administration. Henry Dearborn, of Massachusetts (Secretary of War), ad interim, April I, I80I.

Robert Smith, of Maryland, July 15, I80I. 


\section{President. \\ THOMAS JEFFERSON, Virginia. \\ ViCE-PRESIDENT. \\ GEORGE CLINTON, New York. \\ March 4, I805, to March 4, I809.}

\section{Secretary of State.}

JAMES MADison, of Virginia; continued from last Administration.

\section{Secretary of the Treasury.}

Albert Gallatin, of Pennsylvania; continued from last Administration.

SeCRETARY OF WAR.

Henry Dearborn, of Massachusetts; continued from last Administration. John Smiтh (Chief Clerk), ad interim, February 17, 1809.

AtToRney-General.

John Breckenridge, of Kentucky, August 7, I805.

Caesar A. Rodney, of Pennsylvania, January 20, I807.

SeCretary of the Navy.

Robert Smith, of Maryland; continued from last Administration. 


\section{JEFFERSON.}

In. October, 1799, when President Adams' change of policy towards France was widening the breach in the Federalist party, Secretary Pickering wrote to his friend Cabot: "This measure will unquestionably change the whole administration. . . . Jefferson will be President, Gallatin, Secretary of the Treasury, Madison, Secretary of State, and two other like political characters will be placed at the head of the other Departments." This slate, or fragment of one, proved to be correct.

The balloting in the House of Representatives, necessitated by the fact that the electoral college had made a tie between Thomas Jefferson and Aaron Burr, resulted in a decision on February 17 , I80I ; and the Cabinet list was perfected within a very few days, with the exception of a Secretary of the Navy. The Senate had been summoned for immediate Executive session by the retiring President, which was not agreeable to the Republicans, because of the inability of some of their newly elected members to reach the seat of Government in time to take part in the confirmation of appointments. On March 5, however, President Jefferson nominated James Madison of Virginia to be Secretary of State, General Henry Dearborn of Massachusetts to be Secretary of War, and Levi Lincoln of the same State to be Attorney-General; and all were duly confirmed. The double representation of Massachusetts in the first Republican Cabinet was a part of an attempt to conciliate the chief stronghold of Federalism. And a like purpose was shown in the appointment of Gideon Granger of Connecticut to the Postmaster-Generalship, a stronger position politically than any Cabinet office, because of the patronage that it commanded.

The Secretary of the Treasury, Albert Gallatin of Pennsylvania, assumed office by vacation commission, May I4, a precaution which he himself urged, and which probably grew out of the dislike he had invited from the Federalists by the surveillance over Treasury opera- 
tions that he had assumed in the House of Representatives. Madison himself delayed journeying to Washington, until after his appointment was confirmed, having for the preceding four years preferred to serve Virginia rather than the National Government. Moreover, it was with much delay and difficulty that a Secretary of the Navy was secured. The Republicans regarded the creation of that office as a Federalist extravagance; and it was for several administrations an undesired portfolio. At the middle of July, Robert Smith, a Baltimore lawyer, and a brother of General Samuel Smith, an influential member of Congress, assumed the office.

These delays made it necessary for the President to ask the assistance of the retiring Secretaries. Dexter and Stoddert were requested to remain at their posts for a short time. ${ }^{1}$ And Chief Justice Marshall, in the same letter in which he was invited to administer the oath of office to the incoming President, was requested to attend to certain business in the Department of State. To obviate technical difficulties, Marshall's reappointment was proposed. ${ }^{2}$ Nevertheless, the engaging story is told that at midnight, between March 3 and 4 , Levi Lincoln, the prospective Attorney-General, put Marshall out of the State Department, where he had been signing commissions. Certain it is that on the following day Lincoln was made Secretary of State ad interim.

When the new Congress was organized for regular session, the two vacation Secretaries, Gallatin and Smith, were duly nominated and confirmed, January, 1802 . And the ensuing eight years saw no changes at the Cabinet table, except in the Attorney-General's seat. This was once vacated by resignation and once by death. ${ }^{4}$

${ }^{1}$ Writings of Jefferson, Ford ed., VII, 498.

${ }^{2}$ Writings of Jefferson, ed., I854, IV, 364; Jefferson to Marshall, March 2, 1801 .

${ }^{3}$ Randolph, Domestic Life of Thoinas Jefferson, 307.

${ }^{4}$ On some lists of the Executive Officers of the United States, two names appear at this point apparently without reason: viz., Jacob Crowninshield of Massachusetts, as Secretary of the Navy, and Robert Smith, previously Secretary of the Navy, as Attorney-General. The explanation is as follows: Upon Levi Lincoln's resignation of the Attorney-Generalship, Secretary Smith requested to be transferred to that post, and Jacob Crowninshield 
Superficially, the inauguration of the Republican regime gave new strength to the Cabinet, in that unanimity was now added to concerted action. To Jefferson's "strict construction " principles, the assembled Cabinet was a stumbling block. And yet the collegiate operation of the Executive had attractions for him. Of the dispersed condition into which Adams threw it, there is a very pointed expression of disapproval by Jefferson. ${ }^{5}$ And he was more than sustained in these ideas by his favored counsellor, Gallatin. The Secretary of the Treasury proposed to his chief, as a remedy for the disconcerted action lately experienced, that there should be a general conference every week, and private conferences between the President and each of the Secretaries once or twice a week, and that the days and hours should be definitely fixed. ${ }^{\circ}$ Without adopting such a systematic course, Jefferson showed his ability in this matter, as in others, to put expediency before theories. There is a very interesting passage in a letter that he wrote a year after his retirement. Speaking of the two modes of consultation, separate and assembled, he says: "I practiced this last method, because the harmony was so cordial among us all, that we never failed, by a contribution of mutual views on the subject, to form an opinion acceptable to the whole. I think there never was one instance to the contrary in a case of any consequence. Yet this does in fact transform the Executive into a Directory, and I hold the other method to be more Constitutional." "

But the fact of real consequence to the nature of the Cabinet is that the Republicans lopped off those features that were beginnings of Ministerial Government. Several events disastrous to Hamilton's purposes, had their fruition in the assumption of the Treasury portfolio by Gallatin. The incumbent for the interval between the two

was selected to succeed to the Department that would thus be vacated. Both were duly appointed and commissioned. But Mr. Crowninshield declined; whereupon Robert Smith continued as Secretary of the Navy without reappointment.

${ }^{5}$ Writings of Jefferson, Ford ed., VIII, IO0; Circular to Heads of Departments, November 6, I80I.

-Writings of Albert Gallatin, I, 59; Gallatin to Jefferson, November 9, I8or.

'Writings of Jefferson, Ford ed., IX, 273; Jefferson to Dr. Walter Jones, March 5, I8io. 
great Secretaries, Oliver Wolcott, was not one to play a Chief Minister's part. But Gallatin was a man of a Premier's calibre; and, had his views of Executive relations been those of Hamilton, with whom he shared the foreign birth that forbade either to be accepted by his contemporaries as a real American, his long incumbency of the Treasury Department must have won some promise of permanence for its earliest position. However, we are of the opinion that the personal cause was not the ultimate one in the rejection of Hamilton's theories.

The provision for personal communication between the Secretary of the Treasury and Congress had been rendered inoperative under Madison's leadership of the Lower House. And when Gallatin was added to the Republican forces there, the drastic innovation was made of interposing between the House and the Department a Standing Committee of Finance, avowedly for the purpose of keeping the Executive within the limits of Constitution and law, as the author of the measure understood them. ${ }^{8}$ And Gallatin again exhibited his hostility to allowing the Treasury any privileges with Congress, in connection with the measure of May Io, providing for a regular report from that Department to be laid before Congress at the commencement of every session, the original Treasury Act having left reports to be made at the call of Congress. This supplementary measure originated with a Senate Committee, on which the names of Samuel Dexter and other Federalists appear. Whether it was intended to make an end of investigations of the Treasury, by providing for a great annual report, the records do not show. The act was capable of being executed favorably to an ambitious Secretary. The opposition to this bill was composed of Gallatin and his friend Wilson Cary Nicholas; and the objection was that it was unconstitutional. ${ }^{2}$ There is a pleasant irony in the fact that Gallatin's own reports are the most numerous and probably the most important of all that have been submitted to Congress under this law.

Set over the Treasury himself, Gallatin did not abandon his previous views. The direct address to Congress, which the laws re-

${ }^{8}$ See Chapter, The Cabinet and Congress.

Annals of Congress, X, I799-1801, 709. 
quired of him, called forth an incidental protest to the President; wherein he charged Hamilton with seeking to make the office independent of Executive control, and with distorting the peculiar language of the Treasury Act into an authority for the voluntary presentation of plans of revenue. ${ }^{10}$ His own style was that of response to orders, and he sometimes made formal reference to the limitations of his office. ${ }^{11}$

At the same time, Gallatin enjoyed a primacy of a certain sort. The President was dependent upon him especially, because he was not himself a master of finance. Furthermore, the original Republican policy to reduce National expenditure and pay off the public debt, conveyed to the Treasury a surveillance over all the Departments. More than fortunate in his biographer, Henry Adams, Gallatin has probably been overdrawn in this character, or at least sketched too large in proportion to the Secretary of State. The designation of Madison as administration candidate for the Presidency, after the rupture with Burr, made an end of the Vice-Presidential succession, and gave the Secretary of State a distinction akin to that of hereditary rank. It is in this precedent, we believe, that the priority of the State Department over the others finds its real beginning. Nor is it of less interest that a new form of political strife was hereby introduced into the Cabinet, which was to rend Madison's own administration asunder and banish harmony from that of his successor. Still it is not as a Cabinet officer that Madison is seen in his full stature. The great transactions appertaining to the State Department were conducted at foreign capitals; and Jefferson was more disposed than most Presidents to take a direct part in the diplomatic correspondence. ${ }^{13}$ At the same time, Gallatin's aptitude for foreign affairs gave him a larger share of the President's confidence in this field than any other Secretary of the Treasury has enjoyed except Hamilton. He never appears as a censor over the Foreign Secretary's work; but he is unmistakably conspicuous in all discussions appertaining to it.

${ }^{10}$ Writings of Albert Gallatin, I, 67; Gallatin's Notes on President's Message, November, I8or.

${ }^{11}$ American State Papers, Finance, II, 246-248; Report of November 7, 1807.

${ }^{12}$ Henry Adams, History of the United States, 1, 423, et seq. 
Very contrary to fact, a legend has grown up that Jefferson was exceedingly independent about asking for advice. And the unfortunate statement is finding its way, not only into the biographies and edited works of men of the period, but also into treatises on the American Government, that he refrained from asking the opinion of his Cabinet about the Louisiana Purchase and the suppression of Monroe and Pinkney's treaty with England. ${ }^{13}$

The legend does not at all accord with circumstances made known by Jefferson himself. Inasmuch as the American envoys, Livingston and Monroe, closed with a sudden proposition from the Emperor to dispose of Louisiana Territory, there could be no Cabinet consultation about the question in its final form. But the lesser project to acquire New Orleans was laid before the Cabinet; and the same is true of the ratification of the purchase actually made. ${ }^{14}$ Neither was the Cabinet ignored in the matter of withholding the Monroe and Pinkney treaty from the Senate, though the circumstances were peculiar. A month before the final draft was received, the President took into consideration with the whole Cabinet despatches announcing that the two Ministers were about to conclude a treaty, wherein they were likely to settle satisfactorily the vexed points about colonial commerce, but not to secure the abandonment of impressments. The question was put, whether any treaty yielding the principle of the Non-Importation Act, and not securing the vexed points about American seamen should be accepted; and the opinion was unanimously in the negative. The further question was raised, whether the Senate should be consulted, which was also answered in the negative. The draft of the treaty arrived within a few hours of the

${ }^{13}$ This assertion seems to have its origin in an article published in 1880 , in a leading magazine. "Jefferson, who certainly had as much confidence in his official advisers, among whom were Madison and Gallatin, as any other President, did not ask, I was assured by one of its most trusted members, the advice of his Cabinet, on perhaps, the two most important measures of his Administration-the purchase of Louisiana and the rejection of the treaty concluded by Monroe and Pinkney in I806." (North American Review, CXXXI, 394; W. B. Lawrence, Monarchial Principle in our Constitution.)

${ }^{14}$ Writings of Jefferson, Ford ed., I, 298, Anas, May 7, 1803: ibid., 299, July 16. 
expiration of Congress. And the President, who was confined to his house by illness, was waited upon by members to ask whether the Senate was to be summoned in special session. Without delaying to call the Cabinet together for a second consultation, he carried out the decision already reached there. ${ }^{15}$

The correct notion about this administration is that the Cabinet had as large a share in it as a President, who was well versed in the arts of government, could accord to trusted advisers and agents without impairing his own authority.

${ }^{15}$ Writings of Jefferson, Ford ed., I, 322-323; Anas, February 2, I807 : Henry Adams, History of the United States, III, 430. 


\section{PRESIDENT.}

JAMES MADISON, Virginia.

Vice-PRESIDENT.

GEORGE CLINTON, New York. (Died April 20, 1812.)

President Pro Tempore of the Senate.

WILLIAM H. CRAWFORD, Georgia.

March 4, I809, to March 4, I8r3.

Secretary of State.

ROBERT SMith, of Maryland, March 6, I809.

James Monroe, of Virginia, April 2, i8Ir.

Secretary of the Treasury.

Albert Gallatin, of Pennsylvania; continued from last Administration.

SECRETARY OF WAR.

JoHn Smrth (Chief Clerk), ad interim; continued from last Administration. William Eustis, of Massachusetts, March 7, I809.

James Monroe, of Virginia (Secretary of State), ad interim, December I4, 1812.

John Armstrong, of New York, January 13, I8r3.

Atrorney-General.

Caesar A. Rodney, of Pennsylvania; continued from last Administration.

William Pinkney, of Maryland, December II, I8Ir.

SeCretary of the Navy.

RoBert SMrte, of Maryland; continued from last Administration.

Paul Hamilton, of South Carolina, March 7, i809.

Charles W. Goldsborough (Chief Clerk), ad interim, January 7, r813.

William Jones, of Pennsylvania, January I2, I813. 
President.

JAMES MADISON, Virginia.

Vice-President.

ELBRIDGE GERRY, Massachusetts. (Died November 23, 1814.)

President Pro Tempore of the Senate.

JOHN GAILLARD, South Carolina.

March 4, 1813, to March 4, 1817.

Secretary of State.

James Monroe, of Virginia; continued from last Administration.

James MonroE, of Virginia (Secretary of War), ad interim, September 30, I8I4.

James Monroe, of Virginia, February 28, I815.

SeCretary of the Treasury.

Albert Gallatin, of Pennsylvania; continued from last Administration.

William Jones, of Pennsylvania (Secretary of the Navy), performed the duties of the Secretary of the Treasury during the absence of Mr. Gallatin in Europe in 1813.

George W. Campbell, of Tennessee, February 9, 1814.

Alexander J. Dallas, of Pennsylvania, October 6, i814.

William H. Crawford, of Georgia, October 22, 1816.

\section{SECRETARY OF WAR.}

John Armstrong, of New York; continued from last Administration.

James Monroe, of Virginia (Secretary of State), ad interim, August 3i, I8I4. James Monroe, of Virginia, September 27, i8r4.

James Monroe, of Virginia (Secretary of State), ad interim, March I, I815. Alexander J. Dallas, of Pennsylvania (Secretary of the Treasury), ad interim, March 14, I8I5.

William H. Crawford, of Georgia, August I, i8I5.

George Graham (Chief Clerk), ad interim, October 22, 1816.

AtToRney-General.

William Pinkney, of Maryland; continued from last Administration.

Richard Rush, of Pennsylvania, February Io, I8I4.

SeCretary of the Navy.

William Jones, of Pennsylvania; continued from last Administration. Benjamin Homans (Chief Clerk), ad interim, December 2, i8r4. Benjamin W. Crowninshield, of Massachusetts, December 19, i8i4. 


\section{MADISON.}

The second Republican administration was as shifting and discordant as the first had been stable and harmonious. The long roll of members, including many names that are now unknown, and the list of prolonged ad interim services point to confusion and weakness. This extraordinary flux is to be referred partly to the disasters of the War of 1812 , and partly to President Madison's proverbial malleableness in the hands of Congress.

There had been an understanding among the chieftains of the preceding administration, that, upon Jefferson's retirement and Madison's elevation to the Presidency, Gallatin should be transferred from the Treasury to the State Department. ${ }^{1}$ But, when this plan leaked out, it was so bitterly opposed that the new President did not dare to make the nomination. The significance that was beginning to be attached to the State Department as a stepping stone to the Presidency, coupled with Gallatin's Genevese birth, made his advancement singularly unpopular. And for other reasons than this, the brilliant Secretary had influential enemies. The Republican organization in his own State of Pennsylvania was divided in its attitude towards him; while in New York, he shared in the animosity that the several factions were meting out to the Virginia Republicans.

But the most determined opposition to the proposed appointment was headed by the brother of the Secretary of the Navy, General Samuel Smith, who had a strong enough following in the Senate to dictate to the President, and fixed upon the State Department for his own family. It is said that the Senator from Maryland proposed a compromise at one time, whereby Gallatin might be made Secretary of State, provided the brother in the case were promoted to the Treasury; but that Gallatin himself defeated this by saying that he could not undertake to carry on both Departments at once.

${ }^{2}$ Henry Adams, Life of Albert Gallatin, 388. 
The issue was that Madison was constrained to make a purely ornamental appointment at the critical moment when there was still hope that skillful diplomacy might avert war with England; and Robert Smith became the titular Secretary of State. The vacancy thereby created in the Navy Department was filled by the appointment of ex-Governor Paul Hamilton of South Carolina. The War Department being also vacated, General Dearborn resigning to become Collector of Customs at Boston, another new figure appeared in the person of Dr. William Eustis of Massachusetts, who had derived such knowledge of military organization as he possessed from being a hospital surgeon in the Revolutionary War.

The duties of the State Department, Madison himself continued to discharge, not only doing the proper work of the Secretary of State in the abortive negotiation with the English Minister, Erskine, but even redrafting ordinary correspondence. ${ }^{2}$

However, the figure-head Secretary showed himself very efficient in fomenting opposition to the administration in the Senate, and especially to the commercial regulations, with which the Treasury Department was concerned. ${ }^{3}$ Furthermore, Gallatin suffered a direct humiliation in the defeat of the bill for rechartering the Bank of the United States, on which occasion his enemies in the Senate combined with one accord against him, and Vice-President Clinton gave the casting vote. In March, I8I I, the Secretary of the Treasury offered his resignation. Finding himself directly confronted with the question whether to lose Gallatin or be rid of Smith, Madison was spurred up to calling for the resignation of the Secretary of State, though he sought to sugar-coat the dismissal from the Cabinet with the mission to Russia, this being the earliest resort to a not uncommon expedient. The friction between Smith and Gallatin had called forth some interesting remarks on Cabinet relations from Jefferson, who, in his retirement at Monticello, had assumed the role of administration sage. In one letter, the ex-President says: "The dissentions between two members of the Cabinet are to be lamented. But why

${ }^{2}$ Writings of James Madison, Hunt ed., VIII, 137-I49. Memorandum to Robert Smith.

${ }^{3}$ Henry Adams, Life of Albert Gallatin, 415. 
shoulutritese force Mr. Gallatin to withdraw? They cannot be greater than between Hamilton and myself, and yet we served together four years in that way. .... The method of separate consultation, practiced sometimes in the Cabinet, prevents disagreeable collisions." " This quarrel was also the occasion of the important letter from Jefferson to Dr. Walter Jones, a member of the Virginia delegation in Congress, on the relations and procedure in Washington's Cabinet, that we have quoted several times. Here again, "separate consultation" is suggested, as being more Constitutional than Cabinet meetings and "better calculated too, to prevent collision and irritation, and to cure it, or at least to suppress its effects, when it has already taken place." ${ }^{\circ}$

Before Smith's retirement, overtures touching the State Department had been made to James Monroe, who was Governor of Virginia at the time." There had been a coldness between Monroe and the Jefferson trio, which began with the suppression of the Monroe and Pinkney treaty negotiated with England in I806, and had been aggravated by the attempt on the part of a faction in Virginia to bring Monroe forward instead of Madison as Jefferson's successor in the Presidency. However, a satisfactory understanding was reached. Monroe became Secretary of State by vacation commission, April 12, I8II, being nominated to the Senate November II, and confirmed on the $25^{\text {th }}$, after investigation by a special committee of his accounts while Minister to Paris.

Other Cabinet changes followed. Attorney-General Rodney became disaffected, because his desire for appointment to the Supreme Court of the United States was not granted. December II, I8II, he was succeeded by William Pinkney, of Maryland, with whom Monroe had been associated in his mission to England. Mr. Pinkney was a brilliant lawyer, who consented to divide his time between the duties of Attorney-General at Washington and his professional interests at Baltimore. Changes also occurred in the War and Navy

'Writings of Jefferson, Ford ed., IX, 269; Jefferson to Joel Barlow, January 24, I8Io.

Writings of Jefferson, Ford ed., IX, 273.

'Writings of James Madison, Hunt ed., VIII, 136, Footnote. 
Departments, where gross incompetency was reveaiod so-şon as hostilities broke out between the United States and England. Orse plan that occurred to Madison was to bolster up the War Department by an exchange of portfolios between Eustis and Monroe; ${ }^{7}$ but such project seemed unfeasible, and Monroe began his effective but irregular career as War Minister, by taking charge of that office temporarily, while Eustis retired.

In May, I8I3, Gallatin quitted the administration, although he was legally the incumbent of the Treasury until February, I8I4. Preferring diplomacy to war, Gallatin had seized upon the proposition that Russia should mediate between the United States and England, and had asked to be appointed upon the Commission to St. Petersburg. His own idea was to quit the Treasury permanently. But precedents were not lacking for sending high officers of the Government on foreign missions, two Chief Justices having gone abroad on prolonged diplomatic errands. And the President bethought him to retain Gallatin in the Cabinet, by providing for the Treasury pro tempore, under the existing law for filling casual vacancies, which permitted a department temporarily without a head to be taken in charge by the incumbent of some other, for an interval of six months. Accordingly, the Secretary of the Navy assumed the direction of the Treasury also. The vacancy in the former Department, that had arisen in the previous December, had been filled by the appointment of William Jones, a prominent Philadelphia vessel owner, who had, however, served as a Naval Lieutenant, and was one of the numerous persons to whom Jefferson offered the Navy portfolio in I80I. But the Senate demanded the nomination of a permanent Secretary of the Treasury, before it would confirm Gallatin's appointment on the Commission to Russia. The matter lagged almost a year, while the finances fell into a notoriously bad condition, for which opprobrium has been heaped upon Gallatin, Madison, and Congress alike. ${ }^{8}$ An offer was made to Richard Rush, Comptroller of the Treasury. Finally a feeble appointment was reached, by the selection of George W. Campbell, who was a Senator

'Writings of Gallatin, I, 526.

${ }^{8}$ Life and Correspondence of Rufus King, V, 452. 
from Tennessee, and was brought into line for the post by a chairmanship of the Committee of Ways and Means, in the House. Madison would have preferred Alexander J. Dallas of Pennsylvania, who was one of Gallatin's friends; but he did not venture to nominate him..$^{\circ}$

Almost simultaneously with the change in the Treasury, Pinkney resigned to devote himself to his profession; and Richard Rush succeeded to the Attorney-Generalship.

Meanwhile an ugly quarrel was seething between the State and War Departments, which both convicts President Madison of feebleness in keeping his Secretaries in their proper places, and brings into the high light the special political significence that attached to Cabinet office at this period. The vacancy that had arisen in the War Office at the close of the first season's campaigns had been filled by the appointment of John Armstrong of New York, a newly made Brigadier-General in the United States army. Classed according to the family groups that had served New York for parties, General Armstrong was an important person, being by his family connections a Livingston. Formerly a United States Senator, and later Minister to France, he now ranked with Governor Tompkins as a very eligible candidate for higher honors. His relations with the Virginia Republicans were notoriously bad; and his talents and high connections were offset by a reputation for indolence and underhanded dealing. That he had enemies was clearly shown by the vote to confirm his appointment, which little more than escaped being a tie. Madison sought to justify the appointment ten years afterwards by saying that the War portfolio had been refused in several quarters; and that he yielded the objections against Armstrong to "a belief that he possessed, with known talents, a degree of military information which might be useful, and a hope that a proper mixture of conciliating confidence and interposing control would render objectionable peculiarities less in practice than in prospect." ${ }^{10}$ The ex-President could scarcely have admitted, if it were true, that he had been driven to the selection of a prominent New Yorker for the

\footnotetext{
- Henry Adams, History of the United States, VII, 397.

${ }^{10}$ Madison's Works, ed., ordered by Congress I884, III, 384 .
} 
War Office, by Josiah Quincy's stinging assault upon the administration, in the House of Representatives." But the date of Quincy's speech, and the stigma that it cast upon Monroe's prominence, with the date of the Armstrong appointment, make it a very pertinent question whether such was not the case.

The rival Secretaries were equally awake to the probability that the War would make Presidents. Both had been minor officers in the Revolution. As Secretary of War, Armstrong has been rated as much superior to any of his predecessors. But, Monroe, with the advantages of his temporary incumbency, was prevented by so-called patriotism from withdrawing into his own Department. Armstrong proposed Monroe's name for a Major-Generalship, which the latter would have accepted, on terms that would place him in the highest command. But, on the other hand, Armstrong's failure to recommend the creation of any rank competent to a general command in the field was taken to mean that he was reserving that position for himself, and was intending to establish the War Department at the centre of military operations.

The President now permitted his Secretary of State to advise him as to what should be done at the War Office. Shortly after Armstrong's assumption of his duties, Monroe addressed a letter to Madison, in which he reported the ambitions that were imputed to his colleague, and entered into a curious Constitutional argument againts the combination of a military command with the Secretaryship of War, not failing to put himself at the President's service either for a command or for the Department. When the season's campaigns were over, he wrote again in the same spirit, this time urging Armstrong's removal. ${ }^{12}$

The end came with the burning of Washington, when the Secretary of War incurred the charge of neglect of duty. That Armstrong had really become negligent is hardly proven by his adherence to the decisions reached at the Cabinet meetings on the question of defending the District of Columbia. It is a curious fact too that the Presi-

${ }^{11}$ See infra.

${ }^{12}$ Writings of James Monroe, V, 244-250; Monroe to Madison, December 27, I8I3. 
dent had charged him with exceeding his authority as Head of the War Department, and had even provided a schedule of directions for reporting his acts to his chief. ${ }^{13}$ But certain it is that the panic stricken people of the District blamed the Secretary of War. ${ }^{14}$ There was a report too, afterwards published in justification of Monroe's conduct, that the militia at Georgetown revolted, and made a demand that the defence of the District be taken away from the War Department. ${ }^{15}$ But Armstrong's friends sought to disprove this as a fabrication in the interest of the Secretary of State. ${ }^{18}$ On repairing to Washington, the President was seized with an inspiration to dismiss or humiliate the Secretary of War; and approached that officer, who arrived a little later with suggestions that he take a vacation, or part with a portion of his authority; and a full resignation was the result.

Henry Adams, the masterly historian of this period, says of this denouement: "Between conscious intrigue and unconscious instinct no clear line of division was ever drawn. Monroe, by the one method or the other, gained his point, and drove Armstrong from the Cabinet; but the suspicion that he had intrigued for that object troubled his mind to the day of his death." ${ }^{17}$ Federalist criticism was to the effect that Armstrong had been supplanted, in like manner as it decreed that Gallatin had deserted. ${ }^{18}$

Monroe was at once made Secretary of War ad interim; but not until six weeks afterwards, when he himself urged it upon Madison, did he succeed to the office by full commission. ${ }^{19}$ Furthermore, the President offered the State portfolio to Governor Daniel D. Tompkins of New York, as if to show that he was not reserving a monopoly of political advantage for the latest "favored son" of Virginia. Tompkins declined, however, both because his State needed his services, and the experience of Northern men in Virginia Cabinets had not been such as to encourage those with high am-

${ }^{13}$ Writings of James Madison, Hunt ed., VIII, 286.

${ }^{14}$ Margaret Bayard Smith, Forty Years of Washington Society, I15.

${ }^{16}$ T. L. McKenney, Memoirs.

${ }^{18}$ Kosciusko. Armstrong, Review of McKinney's Narrative, etc.

${ }^{17}$ Henry Adams, History of the United States, VIII, 16r.

${ }^{18} \mathrm{Life}$ and Correspondence of Rufus King, V, 448.

${ }^{10}$ Writings of James Monroe, V, 293. 
bitions. ${ }^{20}$ Like other men from his State, who were out of joint with the Virginia rule, he accepted the Vice-Presidency a little later. The Cabinet vacancies were adjusted by permitting Monroe to fill two places, until the close of the War. In February, 1815 , he returned to the State Department by regular appointment. But he afterwards averred that it was his service in the War Office, rather than his Secretaryship of State, that made him President. ${ }^{21}$

The Executive continued in a state of upheaval to the end of Madison's administration. In December, 1814, Secretary Jones of the Navy had resigned, Benjamin Crowninshield of Massachusetts accepting the post. But a more conspicuous change had occurred in the Treasury. George W. Campbell had retired, after showing himself powerless to extricate the Department from the confusion into which it had fallen; and the dropping out of two or three of the President's enemies from the Senate had made possible the appointment of Alexander J. Dallas. However, this able lawyer entered the administration for only a short time; for, in the spring of 1816 , he expressed a wish to resume his profession, and set the operation of the act to re-charter the Bank of the United States, as the limit of his service in the Treasury. Dallas had also taken his turn at the War Department; for after Monroe's final withdrawal, a temporary incumbency was imposed upon the Secretary of the Treasury, giving into his hands the reduction of the army to a peace footing.

Both Departments were in a broken up condition, during the last year of Madison's presidency. Simultaneously with Monroe's resumption of the State portfolio, General Henry Dearborn had been nominated to be Secretary of War. He had held the same office in the Jefferson Cabinet; but military jealousies entailed by the War with England threatened an adverse vote in the Senate; which was forestalled by the withdrawal of Dearborn's name, and the substitution of that of William $\mathrm{H}$. Crawford of Georgia. This was the introduction of a very important figure into the Cabinet. Crawford had been President pro tempore of the Senate, after the death of

${ }^{20}$ Henry Adams, History of the United States, VIII, 163.

${ }^{21}$ Writings of James Monroe, VI, 3. 
Vice-President Clinton. And he had been conspicuous in that body as the supporter of administration measures. He was one of those who declined the War Department, prior to the appointment of General Armstrong. Like Gallatin, he had been attracted to diplomacy; and, shortly after the latter was despatched to Russia, he had left the Senate to become Minister to France. In I8I5, however, he accepted the War Department, entering upon its duties some months after he was appointed. And a year later, he was transferred to the Treasury. Pending the retirement of Dallas, Madison sought to recall Gallatin; but the former Minister of Finance preferred a diplomatic appointment to the Cabinet portfolio that he had held so long. Presumably Gallatin was not eager to enter the service of Monroe; whose nomination for the Presidency by Congressional caucus had already determined his election. Monroe had not been taken into full fellowship by the original group of Republican chiefs. As a representative of the Gallatin-Dallas tradition, Crawford was next in line. But, he himself was not enthusiastic for the transfer. He was also known to be cherishing the highest ambitions; yet the War Department seemed to satisfy him better than the Treasury, whether by reason of individual preference, or for the prestige that had lately made it the bone of contention in the Executive. According to his own account, he consented to take the Treasury, in order to make it possible for the President to call Henry Clay into the Cabinet. ${ }^{22}$ However, the War Office was less attractive to the rising statesman from the South-West than were his prospects in Congress. And after being declined also by William Lowndes of South Carolina, it fell into the hands of the chief clerk of the Department for a long interval.

A contemporary epitome of the first two Republican administrations is found in a speech by Josiah Quincy, delivered in the House of Representatives, January 5, I8I3, and very famous in its time. It is not a true representation of the workings of the Executivethe unpopularity of the War in New England made that unlikely-; but it is very valuable to the present investigation, because it shows

${ }^{22}$ Writings of Albert Gallatin, II, II-I4; Crawford to Gallatin, October 9, I8I6. 
the wisdom of certain changes that soon came about. Speaking to a bill to provide for the raising of troops for the invasion of Canada, the member from Boston said: "It is a curious fact, but no less true than curious, that for these twelve years past the whole affairs of this country have been managed, and its fortunes reversed, under the influence of a Cabinet little less than despotic, composed, to all efficient purposes, of two Virginians and a foreigner-

"I might have said, perhaps, with more strict propriety, that it was a Cabinet composed of three Virginians and a foreigner, because once in the course of the twelve years there has been a change of one of the characters. But, sir, that change was notoriously matter of form rather than substance.

"I said that this Cabinet had been, during these twelve years, little less than despotic. This fact also is notorious. During this whole period the measures distinctly recommended have been adopted by the two Houses of Congress with as much uniformity and with as little modification, too, as the measures of the British Ministry have been adopted during the same period by the British Parliament. The connection between Cabinet councils and Parliament acts is just as intimate in the one country as in the other.

"I said that these three men constituted, to all efficient purposes, the whole Cabinet. This also is notorious. It is true that during this period other individuals have been called into the Cabinet. But they were all of them comparatively minor men, such as had no great weight either of personal talents or of personal influence to support them. They were kept as instruments of the master spirits; and when they failed to answer the purpose, or became restive, they were sacrificed or provided for. The shades were made to play upon the curtain; they entered; they bowed to the audience; they did what they were bidden; they said what was set down for them. When those who pulled the wires saw fit, they passed away. No man knew why they entered; no man knew why they departed; no man asked whither they were gone." ${ }^{23}$

The aphorism of the "two Virginians and a foreigner," or better "three Virginians and a foreigner," echoing the jealousy that had

${ }^{23}$ Speeches of Josiah Quincy, II, 397-399. 
been muttered since Jefferson broke with Burr, and had been especially outspoken when the State portfolio returned to Virginia, after the Robert Smith episode, shows that the hour was ripe for the new Cabinet geography that Monroe himself introduced on becoming President. Furthermore, the representation of an inner Executive, composed of the President and the two ranking Secretaries, is very applicable to the Jefferson and Madison administrations throughout, except for one or two weak places in the two foremost Departments. But the shifting of the lower end of the Cabinet, so graphically described, had a deeper cause than any connivance to keep the Government in the hands of a triumvirate. Time and again, every one of the three portfolios had been a-begging for an incumbent; and they offered neither sufficient rank nor emolument to retain men of ability, if such were once secured. It was for the War to teach the necessity for improving the condition of those offices. Neither did the influence of the Cabinet upon legislation bear out the comparison with the British Ministry. Quincy had been made unduly eloquent by the connection that he perceived between the Committee on Military Affairs and the War Office, where Monroe's temporary incumbency caused him to stigmatize that gentleman as "one third of the Executive." It is true, however, that the first years of the Republican regime, when Jefferson assisted by Madison and Gallatin, was successfully maintaining his policy of neutrality, had been a season of more than ordinary Executive influence in Congress. 


\section{President. \\ JAMES MONROE, Virginia. \\ Vice-President. \\ DANIEL D. TOMPKINS, New York.}

March 4, 1817, to March 4, I821.

Secretary of State.

John Graham (Chief Clerk), ad interim, March 4, 1817.

JoHn Q. ADAMS, of Massachusetts, March 5, I8I7.

RichaRD Rush, of Pennsylvania (Attorney-General), ad interim, March 10, 1817.

Secretary of the Treasury.

William H. Crawford, of Georgia; continued from last Administration.

William H. Crawford, of Georgia; recommissioned March 5, i817.

SeCRETARY OF WAR.

George Graham (Chief Clerk), ad interim, March 4, I8I7.

John C. Calmoun, of South Carolina, October 8, i8I7.

AtTorney-General.

Richard RUSh, of Pennsylvania; continued from last Administration.

William Wirt, of Virginia, November 13, 1817.

SeCretary of the Navy.

Benjamin W. Crowninshield, of Massachusetts; continued from last Administration.

John C. Calioun, of South Carolina (Secretary of War), ad interim, October I, I818.

Smith Thompson, of New York, November 9, 1818. 
President.

JAMES MONROE, Virginia.

VICE-PRESIDENT.

DANIEL D. TOMPKINS, New York.

March 5, I821, to March 4, I825.

Secretary of State.

JoHN Q. ADAms, of Massachusetts; continued from last Administration.

SeCretary of the Treasury.

William H. Crawford, of Georgia; continued from last Administration.

SECRETARY OF WAR.

John C. Calmoun, of South Carolina; continued from last Administration.

AtToRney-General.

William WIRT, of Virginia; continued from last Administration.

SeCretary of the NAvy.

Smith Thompson, of New York; continued from last Administration.

JoHn Rodgers (Commodore, U. S. N., and President of the Board of Navy

Commissioners), ad interim, September I, 1823.

Samuer L. Southard, of New Jersey, September 16, I823. 


\section{MONROE.}

The merging of Republicans and Federalists into one body, preparatory to a new division upon new issues, made the single party rule of small account in the arrangement of the Monroe Cabinet. For a little while, men sat together at the council board who not only differed in their political antecedents, but were to be conspicuously opposed in their political allegiance in the future. At the same time the geographical code began to be affected by a consciousness that a new section of the country was becoming sufficiently developed to claim recognition in the Executive councils. Monroe was the first President who expressed a desire to represent in the Cabinet the four great quarters of the United States, North, Middle, South and West. "The West" is a term that has constantly changed its meaning; and in the Cabinet talk of 1816-' 17 , it referred only to the old South-West, which had given to the country Henry Clay and Andrew Jackson. Madison's offer of the War Department to Clay had been in line with the purpose more distinctly avowed by his successor. ${ }^{1}$

In selecting his Secretary of State, Monroe was deeply sensible of the impression that had been made upon the public mind by the repeated elevation of that officer to the Presidency. And he was persuaded that the State portfolio must not only be taken away from Virginia, but that it must now be awarded to the North-East, otherwise, his administration would have to look for its whole support south of the Potomac. ${ }^{2}$ Several important consequences are traceable to this decision. By preventing the appointment of Clay, who would have accepted the State portfolio, though he had lately declined the War Office, it had an effect upon the development of the Speakership. It checked the advancement of Crawford, who had lately been put

${ }^{2}$ Writings of James Monroe, V, 347 ; Monroe to Jackson, December I4, 1816.

'Writings of James Monroe, VI, 3; Monroe to Jefferson, February 25, I817. 
over the Treasury, and was favored by the older Republican chiefs for the State Department. ${ }^{3}$ And finally it was the occasion of recalling John Quincy Adams from the diplomatic service and bringing him into line for the Presidency. For, with the geographical limits fixed in favor of the North-East, Mr. Adams stood far above all other candidates both by his diplomatic talents and his experience of foreign affairs.

The delay that attended the completion of this Cabinet seems to indicate that the Executive counsels were not pressing, and that Departmental business jogged at an easy gait, as peace and " good feeling" possessed the country. The new President devoted three and a half months to one of his progresses, before he knew who were to sit at his council table. The day following his inauguration, he had nominated John Quincy Adams to be Secretary of State, William H. Crawford to be Secretary of the Treasury, and Colonel Isaac Shelby, ex-Governor of Kentucky, to be Secretary of War."

The prospective Secretary of State, however, had yet to return from England; and Colonel Shelby declined the War portfolio because of his advanced years. Moreover, the appointment of Richard Rush to succeed Adams vacated the Attorney-Generalship. The War Department thus continued, where Madison had left it, in the hands of its chief clerk, while the retiring Attorney-General supplied both the place that he was vacating and that of the Secretary of State. Failing to find a Secretary of War in the South-West,-and Andrew Jackson, as well as Clay and Shelby declined the post,- the President

${ }^{3}$ Writings of Albert Gallatin, II, 24; Crawford to Gallatin, March 12, 1817.

"Although Crawford was actually transferred from the War to the Treasury Department, on October 22, 1816 , it was by means of a vacation cornmission and he requested the President not to send his nomination to the Senate, until certain difficulties which stood in the way of his accepting the office permanently should be removed. As this was only accomplished on March 3, I817, the last day of Madison's administration, by the passage of an act relating to the internal organization of the Departments, the regular session expired without submitting the appointment to the Senate. Thus it was on March 5, 1817, that Crawford was appointed to the Treasury Department in the regular way. For the single day of March 4, he held the office without legal authority.

- Memoirs of John Quincy Adams, IV, 15. 
finally settled upon John C. Calhoun of South Carolina. During his own incumbency of the State and War Departments, he had been deeply impressed with Calhoun's services on important committees of the House of Representatives. ${ }^{6}$ The Attorney-Generalship was finally accepted by William Wirt, of Virginia, a prominent lawyer who had figured in the trial of Aaron Burr.

This Cabinet is one of the most brilliant ones in the history of the Government. Not only were the State and Treasury Departments ably filled, but the War portfolio was in the hands of a young statesman of a high order of ability. Furthermore, the Attorney-General, if not a more brilliant lawyer than some of his predecessors, lent greater prestige to his office by his long tenure and his more regular connection with the administration. Hitherto the Attorneys-General had spent much of their time away from the seat of Government attending to private practice. But in his Eighth Annual Message to Congress, President Madison recommended that a more suitable provision be made for that officer with reference to his settled residence at the National Capital. ${ }^{7}$ A previous suggestion that fixed residence be required had made William Pinkney resign from the Cabinet in $1814 .^{8}$ Before Wirt's appointment, a measure of this character was passed by Congress. ${ }^{\circ}$ The Navy was a comparatively weak spot in the administration; and had three different incumbents.

The organization of the Navy Department was a vexed question. After the War of 1812, a Board of Commissioners consisting of three naval officers, was established within the Department, to discharge its ministerial duties under the direction of the Secretary. Thereafter, it was President Madison's opinion that the Department ought to be abolished, and its duties assigned to the President of the Board of Commissioners. Monroe, however, was strongly in favor of retaining the Secretaryship. ${ }^{10}$ The question came up, probably in

-Writings of James Monroe, VII, 136; Monroe to Calhoun, December I6, 1827.

${ }^{7}$ Richardson, Messages and Papers of the Presidents, I, 577.

${ }^{8}$ Henry Adams, History of the United States, VII, 398.

' Kennedy, Life of William Wirt, II, 54.

${ }^{10}$ Memoirs of John Quincy Adams, IV, 133, 3ro. 
consequence of the War, of making the four Departments equal, so far as salaries were concerned; but the low estimate of Secretary Crowninshield's ability, and the fact that he lived at a boarding house and quitted Washington as soon as Congress adjourned, sufficed to defeat a bill for that purpose that was brought up in $18 \mathrm{I} 8$, though in Feburary I8I9, such a measure was carried.

The thing that gives the Monroe Cabinet its most distinctive character is the dissension within it that arose from rival aspirations to the Presidency. Adams immediately became conscious of the place in the succession which the traditions of his office accorded to him. Crawford had ventured to dispute the nomination with Monroe in 1816 , and showed in the Congressional caucus 54 votes against 65 of his superior. Though disappointed of promotion to the State Department, he did not lack means to further his candidacy in the Treasury. Moreover, Calhoun was assured of the support of several important States. The Adams Memoirs give a lively account of the ways of making Presidents, when the Congressional caucus was the nominating body; but it is over-colored by the author's suspicions.

It was after Monroe's reelection in 1820 that the various devices for cultivating Congressional favor became most definitely directed ; for all of the Secretaries seem to have respected their chief's presumptive right to a second term of office. These Cabinet rivalries had a bad effect upon the despatching of public business, and the more so, that the Speaker of the House of Representatives was also a candidate for the Presidency. Both Clay and Crawford carried their jealousy of Adams so far as to seriously embarrass the difficult negotiations between the Secretary of State and the Spanish Minister in I8I9. ${ }^{11}$ In the spring of 1822 , Adams declared that the closing Congressional session had been little more than a violent struggle between the Crawford and Calhoun factions in Congress; that each had formed a cabal within that body; and that both were countenancing insidious attacks upon the Secretary of State. ${ }^{12}$

Monroe appears to have accepted presidential wire-pulling as a necessary incident of Cabinets. He treated the rival aspirants with

${ }^{11}$ Morse, John Quincy Adams, I13.

${ }^{12}$ Memoirs of John Quincy Adams, V, 490-5I4. 
painful impartiality, declining to honor with his presence a ball given to General Jackson, at the Secretary of State's, on the anniversary of New Orleans, and refusing, on a summer vacation in Virginia, to visit the Secretary of the Treasury, who lay ill at the Governor's house. In dispensing the patronage he aimed to give each Secretary the control of the appointments within his own Department; and he had all presidential appointments discussed in Cabinet meeting. ${ }^{13}$

If Monroe was informed of Jefferson's suggestion that separate consultation was a good way to prevent friction in the administration councils, he did not act upon it. Although no "Cabinet day" was observed, meetings were held under ordinary circumstances, at intervals of little more than a week. The most exciting consultation of the administration, and one that had strange results in making enemies of Calhoun and Jackson, when its secrecy was violated twelve years later, related to General Jackson's conduct in prosecuting the Seminole War on Spanish soil in 1818. The question whether the Government should sustain the General's high-handed proceedings was the occasion of six Cabinet sessions, which were interrupted by but a single day. ${ }^{14}$ On the Missouri Compromise and other Constitutional questions, written opinions were taken. ${ }^{15}$ It is also an interesting detail that the President's custom of repairing with his Cabinet to the Capitol, on the last night of the session, to read and sign bills, is recorded for the first time of this administration.

A peculiar interest attaches to the relations between Monroe and Adams; since there is much to support the view that the Secretary had a larger share than the President in the great achievements in the field of foreign affairs. The two did not come into conflict on any very large question; but there was abundant friction in small matters. Monroe preserved the forms of subordination with a good deal of stringency; and if Adams entertained a contrary opinion, he yielded it, after he had upheld his side of the case in argument. But he had private chafings, which he confided to his Diary. "This

${ }^{13}$ Fish, The Civil Service and the Patronage, 70.

${ }^{14}$ Memoirs of John Quincy Adams, IV, 107-I16.

${ }^{15}$ Clayton MSS., Benton to Clayton, July 16, 1855; Memoirs of John Quincy Adams, VI, 34 . 
sifting and revising of every important paper that I write is not flattering nor very agreeable," he wrote in the autumn of 1819, apropos of a despatch to the Minister at Madrid. Again he shows himself and Monroe in a heated dialogue concerning the reply to a call by Congress for diplomatic papers in the spring of 1822 , the President reminding the Secretary that he had no ultimate authority in the matter, while the Secretary asserted at least a moral responsibility for the papers that issued from his hand. ${ }^{16}$ An important note to the Russian Minister, which preceded the publication of the Monroe Doctrine, was the occasion of a similar controversy. ${ }^{18}$

Of the relations between the President and the other Cabinet officers, we have less detailed information. Something of the bad feeling which was so pronounced between Adams and Crawford existed also between the Secretary of the Treasury and his chief, growing out of Crawford's impatience to possess the Presidency. ${ }^{18}$ Calhoun and Monroe, on the other hand, preserved the kindly feelings with which their association began, although the Secretary of War is represented by the diarist of the administration as being very independent in his opinions. Wirt, the Attorney-General, is represented as habitually echoing the President. ${ }^{10}$. Undoubtedly the fact that this able Cabinet was at cross purposes with itself was an important factor in making it tractable in the hands of its chief. The administration affords no case of an attempt by the Secretaries to overrule the President.

\footnotetext{
${ }^{16}$ Memoirs of John Quincy Adams, V, 508.

${ }^{17}$ Memoirs of John Quincy Adams, VI, 212.

${ }^{18}$ Writings of James Monroe, VII, 82; Monroe to Ringgold, May 8, 1826.

${ }^{19}$ Memoirs of John Quincy Adams, IV, 36.
} 


\section{President. \\ JOHN QUINCY ADAMS, Massachusetts. \\ Vice-President. \\ JOHN C. CALHOUN, South Carolina.}

March 4, I825, to March 4, I829.

Secretary of State.

Daniel Brent (Chief Clerk), ad interim, March 4, I825.

Henry Clay, of Kentucky, March 7, I825.

Secretary of the Treasury.

Samuel L. Southard, of New Jersey (Secretary of the Navy), ad interim, March 7, 1825.

RICHARD RUSH, of Pennsylvania, March 7, 1825.

SeCretary of War.

JAMES BARBour, of Virginia, March 7, 1825 .

Samuel L. Southard, of New Jersey (Secretary of the Navy), ad interim, May 26, 1828.

Peter B. Porter, of New York, May 26, I828.

Attorney-General.

William Wirt, of Virginia; continued from last Administration.

Secretary of the Navy.

Samuel L. Southard, of New Jersey; continued from last Administration. 



\section{JOHN QUINCY ADAMS.}

The peculiar political situation of 1824-'25 gave rise to the first coalition Cabinet. The presidential election divided the party into four great factions, supporting Jackson, Adams, Crawford, and Clay, the Calhoun element being temporarily obscured as a separate interest by the election of its favorite to the Vice-Presidency. A decision between the three candidates who had stood highest in the electoral colleges was reached in the House of Representatives, on February 9, 1825, in favor of Adams, who had stood second to Jackson both in the colleges, and by the popular vote. Two days later, Henry Clay received an offer of the State portfolio; the reasons for which selection, as given by Adams himself were, first, that $\mathrm{Mr}$. Clay had been a prominent candidate for the Presidency, commanding the western vote, and second, that he was the best fitted man for the place in the country. ${ }^{1}$

The familiar charge of a "corrupt bargain" has been disproven to the satisfaction of all unprejudiced persons. President Adams published an explicit denial at the close of his administration. ${ }^{2}$ And Clay's contemporary correspondence affords no ground for suspicion. So early as January 8 , he announced his determination to support Adams, but with an enthusiasm that was cold enough to consist with their previous relations. Jackson, he could not support, because he did not approve of military heroes for Presidents; Crawford was incapacitated by a stroke of paralysis; therefore, Adams was the least of evils. ${ }^{3}$

That Jackson and his friends should accept such denial was not to be expected, and references to the "corrupt bargain," "the Coalition," and "Mr. Clay's administration " adorned their correspondence

${ }^{1}$ Memoirs of John Quincy Adams, VIII, 174.

${ }^{2}$ National Intelligencer, March II, I829, John Quincy Adams to a Committee of Essex and Middlesex, N. J.

${ }^{8}$ Clay's Works, ed., 1904, IV, I09-1 i6. 
to the last. The charge was not confined in the beginning to the Jacksonians; but was caught up by the Calhounites, the Crawford men, and the Dewitt Clinton group." And its animus lay in the consideration that the State Department was still regarded as a stepping stone to the Presidency; and that a comparatively new aspirant had possessed an old vantage ground. Clay himself had faith at this time in the efficacy of the Cabinet succession, and was influenced by it to quit the Speakership for the State Department. ${ }^{6}$

The Crawford faction, Adams would have represented by retaining Crawford himself. On February 10, the President-elect invited Crawford, Southard, and Wirt to continue in their respective offices. But the Secretary of the Treasury, perhaps influenced by his physical condition, declined. The portfolio was accordingly conferred upon Richard Rush of Pennsylvania, who had been the last of Madison's Attorneys-General, and had become Minister to England under Monroe. In this appointment is found the beginning of the special association of the Keystone State with the Treasury portfolio, which grew out of her peculiar interest in the policy of protection, and continued until the Civil War. Inasmuch as Mr. Rush had been out of the country for some years, his preference for Jackson for the Presidency may not have entered particularly into his selection. For the War Department, however, Adams went so far as to consider General Jackson himself, though he was deterred from making an offer by the assurance that it would be received "in ill part." " The portfolio was accordingly conferred upon Senator James Barbour of Virginia, a former Governor of that State, and a political supporter of Crawford's. If the Jackson interest was not strongly in evidence at the Cabinet table, it was sufficiently recognized by the retention of John McLean as Postmaster-General.

Many things combined to deny to the John Quincy Adams administration the prestige enjoyed by that of Monroe. The level of ability declined; for Secretaries Rush and Barbour did not supply the loss

' Clay's Works, ed., I904, IV, II3, Clay to Francis Brooke, January 28, 1825.

${ }^{5}$ Clay's Works, ed., I904, IV, I15, Clay to Francis Brooke, February 18, 1825; ibid., I17, Crittenden to Clay, February, 15, 1825.

${ }^{6}$ Schurz, Henry Clay, I, 249. 
of Crawford and Calhoun. Indeed the new Secretary of the Treasury had so little predisposition for his office that, upon his belated arrival at Washington, he asked to change places permanently with the Secretary of the Navy, who had had charge of the Treasury ad

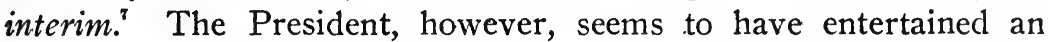
unduly high opinion of his Minister of Finance; at least he was able, when dissuading him from thoughts of resignation, to pronounce his Treasury Reports superior to any since Hamilton's.

Moreover, this was one of the few administrations, which have been politically out of joint with Congress. The reproach cast upon the election had told against the President's support from the outset; and, as party distinctions revived, the opposition secured a sweeping majority for the Congress which sat from 1827 to 1829 . The strain of the situation is indicated by the attempts to curtail the powers of the Executive by amendments to the Constitution. These included propositions to limit the tenure of the President to a single term, to choose him by popular election, to do away with the decision of contested elections by the House of Representatives, and to forbid the appointment of members of Congress to executive offices.

In its inner relations, this administration was unusually harmonious. Upon retiring, President Adams saw fit to publish a letter wherein he declared that more than ordinary concord had prevailed, and commended the services of each Secretary individually. And this tribute seems to have been more than a formal courtesy, though it probably amounted only to that, when several later Presidents followed Adams' example.

The most serious disagreement that arose concerned the appointment of the General-in-Chief of the army in I828. Secretary Rush in giving an account of this to James K. Polk and James Buchanan, nearly twenty years afterwards, said that it came near to breaking up the Cabinet; but the spectacle of broken Cabinets had then become so common that the ex-Secretary probably exaggerated its possibilities. According to the account, Generals Scott, Gaines, and

'Memoirs of John Quincy Adams, VII, 38.

${ }^{8}$ Memoirs of John Quincy Adams, VII, 4or.

'Ames, Amendments to the Constitution, pp. 339-343. 
McComb were all under consideration, Scott being the choice of Clay, who was very ardent in his preference, and likewise of Barbour, Southward and Wirt. After the discussion had been going on six weeks, President Adams asked Secretary Rush, who had hitherto taken no part in it, for his opinion. The reply was decidedly in favor of McComb. The President had not before expressed his own opinion; but upon hearing this, "he straitened himself up in his seat," so the account runs, " and in his peculiar manner said, "and I think so too; " "and General McComb was appointed. ${ }^{10}$

Clay proved himself a loyal subordinate. The occasional speeches which he and one or two of his colleagues made, while visiting their own States, were probably the beginning of Cabinet activities on the stump. At the hands of Jacksonian editors, this administration was roundly abused for seeking to perpetuate itself, though probably none was ever less offensive in its methods. It was a time of transition between modes of President-making; and it suited the humor of Duff Green, editor of the Telegraph, to take high ground against campaign speeches by Cabinet officers. The absence of Clay and one or two others from the seat of Government gave rise to the name of "the travelling Cabinet," and their visits to their homes were styled "electioneering perambulations." "

Early in 1828, several of the Secretaries wished to resign, Clay pleading ill health, and Rush and Barbour desiring diplomatic appointments. Adams was deeply sensitive at having his administration break up, while political defeat stared him in the face. And he persuaded Clay and Rush to remain, though the former was obliged to leave his Department to his chief clerk for an extended period. Secretary Barbour, who especially desired an opportunity to go abroad, was made Minister to England; and the vacancy in the War Department was filled by appointing General Peter B. Porter, of New York, in which choice the President yielded to his Cabinet.

The break in the administration called forth a pathetic plaint from Mr. Adams: "In my own political downfall, I am bound to involve

${ }^{10}$ Polk's Diary, XI, 63, 64, January 10, I847; Curtis, Life of James Buchanan, I, 606; Rush to Buchanan, June 2, I846.

${ }^{11}$ The Telegraph, 1830, July 9, 15, 16. 
unnecessarily none of my friends. Mr. Clay thinks that the appointment of Governor Barbour would not have a bad political effect upon the administration. In this he is greatly mistaken. The effect will be violent, and probably decisive. But why should I require men to sacrifice themselves for me?" ${ }^{12}$

The long Republican regime engendered a tenaciousness of office among Cabinet Ministers that is well illustrated by a question on the part of Attorney-General Wirt, as to whether he and his colleagues ought to resign if Adams failed of reelection, and by the answer of ex-President Monroe to whom Wirt turned for advice. Monroe herein enters into a discussion of Cabinet tenure, which is in curious contrast with later views. The liability of Department Heads to impeachment, he says, implies a tenure depending upon good behavior in office. Still they are the President's councillors, and so ought to be changed, when any change of principles occurs in the Government; but never to become the mere appendages and creatures of the existing incumbent of the Presidency. However, it is hard to see how they could remain in office without the President's sanction, which view is less applicable to the Attorney-General than to the other Cabinet officers, because the President has less connection with his duties and less responsibility for them. ${ }^{13}$

But, immediately after the elections showed that General Andrew Jackson would succeed to the next presidential term, the Telegraph, put an end to all doubt as to the propriety of Cabinet resignations by publishing the following: "We take it for granted that he (Jackson) will reward his friends and punish his enemies. .... He is expected to punish Messrs. Clay, Rush, Southard, Porter, Wirt and others." On March 3, the entire Cabinet put their resignations into the hands of President Adams, and vacated the Departments.

${ }^{22}$ Memoirs of John Quincy Adams, VII, 526.

${ }^{18}$ Kennedy, Life of William Wirt, II, 22I ; Monroe to Wirt, October 24, I828. 
President.

ANDREW JACKSON, Tennessee.

Vice-President.

JOHN C. CALHOUN, South Carolina. (Resigned December 28, 1832.)

President Pro Tempore of the Senate. HUGH LAWSON WHITE, Tennessee.

March 4, 1829, to March 4, 1833.

Secretary of State.

James A. Hamilton, of New York, ad interim, March 4, I829.

Martin Van Buren, of New York, March 6, i829.

EDWARd Livingston, of Louisiana, May 24, 1831 .

Secretary of the Treasury.

Samuel D. Ingham, of Pennsylvania, March 6, 1829.

Asbury Dickins (Chief Clerk), ad interim, June 21, I83I.

Louis McLane, of Delaware, August 8, 1831.

\section{SECRETARY OF WAR.}

John H. Eaton, of Tennessee, March 9, I829.

Philip G. Randolph (Chief Clerk), ad interim, June 20, I83I.

Lewis Cass, of Ohio, August I, I831.

ROGER B. TANEY, of Maryland (Attorney-General), ad interim.

\section{AtTORNey-General.}

John M. BerRien, of Georgia, March 9, 1829.

ROGER B. TANey, of Maryland, July 20, 1831 .

Postmaster-General.

WILliam T. BARRY, of Kentucky, March 9, I829.

Secretary of the Navy.

Charles Hay (Chief Clerk), ad interim, March 4, 1829.

John Branch, of North Carolina, March 9, 1829.

John Boyle (Chief Clerk), ad interim, May 13, I83I.

LEVI Woodbury, of New Hampshire, May 23, I83I. 
President.

ANDREW JACKSON, Tennessee.

Vice-President.

MARTIN VAN BUREN, New York.

March 4, I833, to March 4, I837.

Secretary of State.

Edward Livingston, of Louisiana; continued from last Administration. Louis McLane, of Delaware, May 29, 1833.

JoHN Forsyth, of Georgia, June 27, 1834.

Secretary of the Treasury.

Louis McLane, of Delaware; continued from last Administration.

William J. Duane, of Pennsylvania, May 29, 1833.

Roger B. TANey, of Maryland, September 23, I833.

McClintock Young (Chief Clerk), ad interim, June 25, 1834.

Levi Woodbury, of New Hampshire, June 27, I834.

SECRETARY OF WAR.

LEwis Cass, of Ohio; continued from last Administration.

CAREY A. HARRIS, of Tennessee (Commissioner of Indian Affairs), ad interim, October 5, 1836 .

Benjamin F. Butler, of New York (Attorney-General), ad interim, October 26,1836 .

Benjamin F. Butler, of New York, commissioned March 3, 1837, ad interim.

Attorney-General.

ROGER B. TANEy, of Maryland; continued from last Administration.

Benjamin F. Butler, of New York, November 15, 1833.

\section{Postmaster-General.}

WILLIAM T. BARRY, of Kentucky; continued from last Administration. Amos Kendall, of Kentucky, May I, 1833.

SeCretary of The Navy.

Levi Woodbury, of New Hampshire; continued from last Administration. Mahlon Dickerson, of New Jersey, June 30, I834. 


\section{JACKSON.}

The blast of democracy, that, in I828, elected a frontier President, who was primarily a military hero, caught the Cabinet in its course. And, while the more striking practices and regulations that were blown in upon it, proved to be personal with General Jackson, or peculiar to him and his disciples, the more popular character that began to be induced on the political side of the Cabinet has remained a permanent factor in Executive relations.

The first new feature to engage the attention is the vigorous slatemaking. For, although the entire administration had changed once before, at the accession of the Republicans in I8or, there had not as yet been an assured place for the Assistant-Cabinet-maker. On this occasion, that personage was not so ubiquitous as he has become with modern means of communication; but he was much in evidence at Washington, where the President-elect arrived so early as February II, I829.

In making up his official household, General Jackson put foremost the personal stipulation that some one of his Secretaries should be primarily an old confidential friend, to whom he could unbosom his troubles and perplexities without restraint. For this place of trust, he first made overtures to Judge Hugh L. White of Tennessee, who declined entering the administration. The second choice was Major John H. Eaton, Senator from Tennessee, a comrade of Jackson's congressional life, and one of his biographers, but a man who was enough younger than he to be regarded with a sort of paternal interest. To taking Major Eaton into the administration, both politicians and friends saw objections private and public alike; but their remonstrances only aroused the old hero's stubbornness to the extent of his challenging the supernatural powers to move him from his determination. And his favorite was slated for the War Department. With that point carried, Jackson showed himself more amenable to influence than the issue justified. 
Especial interest attaches to the placing of the State portfolio at this time. In the appointment of Martin Van Buren, New York was recognized as the Empire State, and the Old Dominion was superseded, though very much of the political meaning that had attached to the portfolio was now at an end. It is stated, in one place at least, ${ }^{1}$ that Littleton W. Tazewell, Senator from Virginia, was offered the post. Certain it is that the Cabinet slates that went around among the more aristocratic party men included Tazewell's name, as they did that of Langdon Cheves of South Carolina. But it seems almost inexplicable that the most eligible of Virginia Republicans, after the passing of the earlier group, should have refused the place that tradition marked for him. Such appointment must have materially altered the spirit of the administration. Furthermore, New York had special claims to being taken into the closest alliance with the National Executive, because her factions were uniting into parties that had given Jackson a clear majority. Jackson had been supported there in I824 by Governor Dewitt Clinton, while Van Buren, who was in the United States Senate at the time, had preferred Crawford, and the delegation in the House of Representatives had given the vote of the State to Adams. Then an alliance had followed between Clinton and Van Buren for the support of Jackson. The State election of 1828 had made Van Buren Governor, though it was shortly taken for granted that Jackson would call him into the administration. Meanwhile, Clinton's death left him to the undisputed leadership of the party. ${ }^{2}$

Pennsylvania, who had fastened her hands upon the Treasury portfolio in 1825, sent her delegation to claim it again; furthermore the agreement upon a member of that body, Representative Samuel D. Ingham, was in the interest of Calhoun, who was again elected to the Vice-Presidency and, in his forecastings of higher elevation, counted upon a support in the Keystone State.

The Navy portfolio and the Attorney-General's office were assigned to John Branch and John M. Berrien, Senators from North Carolina and Georgia. Considerations of locality probably had much to do

${ }^{1}$ Tyler, Letters and Times of the Tylers, I, 479.

${ }^{2}$ Alexander, A Political History of the State of New York, I, 335-343-346. 
with this arrangement. These two members, together with Ingham of the Treasury, were at once designated as the Calhoun wing of the Cabinet; but Jackson himself asserted that they were first proposed by Major Eaton. ${ }^{3}$

A sixth member was now added to the body of official advisers to the President. February 23, the Philadelphia National Gazette published the rumor that both the Vice-President and the PostmasterGeneral were to become Cabinet officers. And on the 26th, the Telegraph, which filled the newly created role of administration organ, confirmed the report so far as the Postmaster-General was concerned. The editor further proceeded to defend the innovation by arguing that neither the law nor the Constitution forbade the President to call any person whom he pleased, even a private citizen into his Cabinet consultations; and naively remarking that the only effect of this change of status in the Head of the Post-Office would be to place the immense patronage of the Department more directly under the control of the President, and to cause the policy of all parts of the Government to harmonize; adding further that General Jackson had been elected by the people to reform existing abuses, and that he was not accustomed to do things by halves.

It was the original intention to retain Postmaster-General McLean of Ohio, who had been appointed some six years before by Monroe, and had been undisturbed by Adams, though he was known to be using the patronage for Jackson's election. But, when the existing incumbent showed signs of intractibility about the proscription of postmasters, some of whom were his own appointees, he was provided for by elevation to the Supreme Bench. Thus the distinction of being the first Postmaster-General with Cabinet rank fell to Major William T. Barry of Kentucky, a member of the Jackson central committee in the late campaign.

The approved slate made an unprecedented draught upon Congress, taking three men out of the six from the Senate, and a fourth from the House of Representatives. Inasmuch as the unsettled condition of the Senate made doubtful the confirmation of an incoming Cabinet with different principles than the outgoing one, the pre-

${ }^{8}$ Jackson MSS., Memorandum of I831. 
caution was taken of having Eaton, Branch, and Berrien hold their seats, until the Secretaries of the State and Treasury Departments had been confirmed. Accordingly, the appointments were not complete until March 9. By transferring legislators to the Executive in this manner, Jackson laid himself open to the charge of gross inconsistency. Furthermore, his previous stand against such procedure was fresh in the public mind, because the calls for Constitutional amendment provoked by the elevation of Clay from the Speakership to the State Department, had issued chiefly from the Legislature of Tennessee." Some explanation was necessary. Accordingly, in his First Annual Message to Congress, the President entered the plea that the Cabinet and certain other high officers ought to be exceptions to any rule of exclusion, because these positions called for political experience and the best talent. ${ }^{.}$

The new Cabinet was admittedly a weak one. Historically, it has a prominent figure in Van Buren; but the great leader of the New York Democracy was only beginning to be distinguished in the National theatre. Among the aristocrats of the party there was some criticism of the falling off of quality. But an answer to this that came from Cambreling of New York, an administration favorite in the House of Representatives, was that the new Cabinet was infinitely better fitted for harmony, practical work, and the interests of the whole country, than if it had contained all leaders and no wheel-horses.

A greater force in the administration was the "Kitchen Cabinet." The "Kitchen Cabinet" legend, which owes its serious form to James Parton, and its humorous one to Major Jack Downing, who was Jackson's Mr. Dooley, has fallen in its turn into the hands of destructive criticism. It is unpopular with Jackson's ardent admirers. And attempts have been made to reduce it to an absurdity, or to show that it is a mere extravaganza upon a practice which Jackson shared with most Presidents. The legend has too strong foundations, however, to be swept away. Minute criticism would discover that the Kitchen Cabinet had a more irregular existence and a less definite

${ }^{4}$ Ames, Amendments to the Constitution, 31-32.

${ }^{5}$ Richardson, Messages and Papers of the Presidents, II, 448. 
personnel, than the old version implies; but it would not detract very much from its activities. Running through Jackson's papers, for the period of his Presidency, is the term "Cabinet proper" to designate his official advisers, which seems to suggest that he himself recognized some under-Cabinet.

The destinctive fact about Jackson's Kitchen Cabinet is that he gave his counsels to men who were primarily politicians, a class that sprang up, so far as the National Government was concerned, with the democratising of politics. A little later, an excellent specimen of the same type appeared in the ranks of the other party in the person of Thurlow Weed of New York, who, without establishing himself at Washington, influenced the political side of Whig and Republican administrations from Harrison to Lincoln.

The individuals of this sort, whose influence with Jackson is most distinctly traceable, are Amos Kendall, who had been a party editor in Kentucky, before he appeared at Washington in the train that awaited the distribution of spoils; General Duff Green, editor of the Telegraph, who was shortly succeeded by Frank P. Blair, editor of the Globe, the latter sheet being set up by the administration, after the rupture between Jackson and Calhoun; and Major W. B. Lewis, an old friend of Jackson's, who shared his life in the White House. The usual statement includes also Isaac Hill, editor of a party sheet in New Hampshire, who was arranged into the Senate after failing of confirmation to the office Jackson had set for him. And Secretaries Van Buren and Eaton, being the only Department Heads that Jackson took into his confidence, are described as belonging to both Cabinets. Early in the administration the opposition newspapers began to call attention to the undue prominence of editors and managers at the Executive Mansion, with such phrases as "Duff Green, President de facto," "Jackson, Lewis \& Co.," and later "Blair, Kendall \& Co."

The Kitchen Cabinet was concerned primarily with party manipulation; Secretary Ingham once referred to it as the "confidential political council." " Upon this aspect of it, Major Lewis throws interesting light in speaking of the first gicat National nominating conven-

${ }^{6}$ Niles Register, XL, 413, Ingham to Jackson, July 26, $183 \mathrm{I}$. 
tion. "I well remember," he says, writing to some Ohio politician, " you brought Governor, then General Lucas to my office with most, if not all the other delegates from Ohio, that we might talk over and arrange matters before they left for Baltimore. . . . General Lucas was made presiding officer of that great Convention at my suggestion, and by my arrangement." " Jackson also preferred these men over his official advisers in dispensing the patronage. Moreover his disregard of official conventions allowed them a larger participation in matters of state than has been the lot of other men of their stamp. Their influence is traceable throughout the long quarrel with the Bank of the United States. Major Lewis was fixed upon by the officers of the Bank as their most influential go-between with the President; ${ }^{8}$ and Amos Kendall was general manager for the removal of the United States deposits.'

One of Jackson's boldest innovations was the discontinuation of Cabinet meetings. Four months after the inauguration, Niles Register, published the following: "No Cabinet council has been held since the present administration came into office and the presumption is that the President does not approve of formal assemblages of the Cabinet for the purpose of getting their views on important questions." ${ }^{10}$ The innovation called forth a protest from a group of Congressmen, members of the Kentucky and Tennessee delegations, who held a caucus upon the situation. The principals were George M. Bibb and Charles A. Wickliffe, Representatives, and Felix Grundy, a Senator. ${ }^{11}$ In March, I830, Bibb communicated to the President a request that he hold " councils composed of all of the Heads of Departments." Jackson did not immediately acquiesce; but a year later, when the Cabinet had been reorganized, the sessions were restored. Indeed, Bibb asserted, referring to the matter later, that he was informed from the most authentic sources that the sessions were held

"Jackson MSS., Letter of W. B. Lewis, March 15, 1839.

${ }^{8}$ Catteral, Second Bank of the United States, 182-185.

${ }^{\circ}$ Niles Register, XXXVII, 378; January 30, 1830; Jackson MSS., I833, Kendall to McLane, March 16, Kendall to Jackson, March 20; Autobiography of Amos Kendall, 378-379.

${ }^{10}$ July II, I829.

${ }^{11}$ Memoirs of John Quincy Adams, VIII, 477. 
weekly, a statement upon which Jackson's general attitude towards his advisers throws a good deal of doubt." Although this caucus was not an especially representative body, being apparently composed of friends who wished to save Jackson from criticism, the episode has a good deal of significance.

In the vacation of Congress of I83I, the administration was reorganized ; and, in its dissolution, the first Cabinet was sensationally conspicuous. The rupture in the Executive had a two-fold animus. Jackson and Calhoun had quarreled, and Van Buren had become ingratiated in Jackson's favor as his chosen successor.

The breaking up began with the schism in Washington society about the Eatons. Shortly before the inauguration, Major Eaton, under circumstances to which some scandal attached, had married the daughter of the landlord of himself and Jackson during their congressional comradeship. Mrs. Calhoun refused to recognize Mrs. Eaton; and the ladies of the Cabinet and the diplomatic corps followed her example. Jackson, whose sympathies were the more strongly enlisted, because domestic slanders, called forth by a fierce political canvas, had contributed to the recent death of his own wife, undertook to arbitrate the affair, without success. ${ }^{13}$ But Van Buren, whose wife was not living, was shrewd enough to take the President's side; and Barry, the Postmaster-General, who had his new rank to be grateful for, did likewise. In the parlors of Washington, meanwhile, the affair was being talked over as the reason why the Cabinet did not meet. And Jackson received new but false light, when somebody asked him, whether Major Eaton were not politically opposed to Calhoun.

The President's suspicions were promptly strengthened by the singularly coincident disclosure of the secrets of the Cabinet consultation of twelve years before on his conduct in the Seminole War. When it was whispered that Calhoun, the then Secretary of War, had stood for reprimanding him for his proceedings in Florida, every untoward event of his presidency was clothed with new meaning. The Eaton scandal had been a persecution, designed to drive his

\footnotetext{
${ }^{12}$ Jackson MSS., Letter by George M. Bibb, January 22, I832.

${ }^{13}$ Jackson MSS., Eaton Papers.
} 
favorite Minister from the Cabinet; the defeat of appointments, and the failure to ratify a treaty had been meant to discredit the administration. It was all a "horrible plot" of the Vice-President's to secure the succession for himself; and half of the Cabinet were in it."

The person who cares to trace through the columns of the Telegraph and Globe the circuitous route by which the secrets of Monroe's Cabinet were conveyed to Jackson, is satisfied that, if there was any plot, it was on Van Buren's side. Ex-Secretary Crawford had disclosed the matter to Senator Forsyth; and it had come to the knowledge of James A. Hamilton, Van Buren's political agent, during the Jackson campaign. ${ }^{15}$ The work of using it to vacate a place in Jackson's favor for Van Buren was so well attended to by Hamilton, that his chief was able to disclaim any knowledge of the affair. ${ }^{18}$

The Cabinet dissolution began with the resignations of Van Buren and Eaton. The retiring Secretary of State gave out in a published letter that, inasmuch as President Jackson had consented to accept a second term of office, and he himself had been named as next in the line of succession, he could not properly continue in the Cabinet, because his presence would be likely to invite attack against the measures of the administration. ${ }^{17}$

This novel doctrine was one of Jackson's contributions to the body of Cabinet regulations. According to a statement that he made some years after his retirement, he had entered upon his administration, with a set of "written rules," one of which excluded from membership in the Cabinet any person, who aspired to the Presidency. ${ }^{18}$ And an editorial in the Globe, of the time of Van Buren's resignation, promulgated the new doctrine, with lessons drawn from the MonroeArmstrong quarrel of Madison's administration, the political strife in Monroe's Cabinet, and the "corrupt bargain" between Adams and Clay. ${ }^{10}$ Jackson was thoroughly sincere in his hostility to the "Sec-

\footnotetext{
${ }^{14}$ Jackson MSS., Memorandum of I831; The Globe, July 13, I831.

${ }^{15}$ The Telegraph, February 17, 22, 25, 1831.

${ }^{18}$ The Globe, February 25, I831.

${ }^{17}$ The Globe, April 20, 1831.

${ }^{18}$ Polk MSS., Jackson to Blair, November 29, 1844 .

${ }^{18}$ June I6, I83I.
} 
retary dynasty;" and he handed down the principle to those Presidents who were his political disciples.

With the resignations of two Secretaries tendered voluntarily, the President called for those of the others, upon the ground that the Cabinet had come together in great harmony, and as a unit, and that it would cause unjust misconceptions and malignant misrepresentations, if two members were permitted to retire without the others withdrawing at the same time. ${ }^{20}$ It is not surprising that this novel argument for the retiring of the Cabinet as a body failed to carry conviction. In fact Mr. Barry was continued in the Post-Office Department, upon the ground that the reasons for which the others had been retired did not apply to him. The deposed officers were swift to make their grievances public; and the newspapers aired all the scandals and sensations of the administration, until the time, when the assembling of Congress gave first place to the question, whether the vacation Cabinet could be confirmed. After six weeks of investigation of the grounds for the late dissolution, and of examination of the antecedents of the new appointees, this was accomplished. But Van Buren's appointment to be Minister to England was defeated. The second Cabinet was a much abler and more dignified body than the one that had been so abruptly dissolved.

The most radical change in the order of Executive relations wrought by Jackson grew out of his famous war on the Bank of the United States. The question here involved, stated in its most specific form, is, whether the Treasury Department is, or rather was, subject to the direction of the President in like manner with the other Departments. The distinctive features of the statutes relating to the Treasury have been already noted. ${ }^{21}$ The head of that Department had his duties defined in a way that made him more subject to the orders of Congress than the other Secretaries; and he was also granted some privileges with that body which the others were not. Furthermore, in defining his general duties, the law was obscure as to what authority should issue the orders, Congress or President. The relations of the Departments with Congress had required further

\footnotetext{
${ }^{20}$ Jackson MSS., Jackson to Inglaam, April 20, 1831.

${ }^{24}$ See Chapter, The Origin of the Cabinet.
} 
settlement almost immediately. But, on the Executive side, no real issue had as yet been raised. That Washington should dictate to Hamilton in his own Department, or Jefferson to Gallatin, carries a personal incongruity. Between Monroe and Crawford, there had been friction, and the President had chafed under the Secretary's power to transmit the Annual Report from the Treasury to Congress, without first submitting it to the Chief Executive. ${ }^{22}$ But in the next administration, Secretary Rush had submitted those reports to President Adams. ${ }^{23}$ Jackson forced an issue, from which the Presidency emerged with strengthened powers.

The Act of April Io, 18I6, under which the Second Bank of the United States was established, provided that the Government funds should be deposited in the Bank or its branches, unless the Secretary of the Treasury should otherwise order and direct; in which case that officer should report his reasons to Congress. The story of how Jackson anticipated the movement for a recharter of the Bank in his early messages, how he moderated his tone, under the influence of Secretary McLane, who became head of the Treasury in I83 1 , how the act for the renewal of the charter was obtruded upon him as a campaign issue in 1832 , of the veto, and of his triumphant reelection over Clay, the advocate of the Bank, is familiar.

Soon after Jackson's reelection, the Globe, began to agitate the removal of the Government deposits. March I9, I833, the President called for the written opinions of his official Cabinet. The day before he had asked for the written opinion of Amos Kendall, who also favored the Secretary of the Treasury with voluntary advice. And the unconventional procedure called forth from the Government directors of the Bank a written suggestion to the President that the Secietary would be a more suitable agent than Mr. Kendall for communication between the Executive and themselves. ${ }^{24}$ Secretary McLane took the stand that the law under which the Bank was chartered, vested the control of the deposits in the head of the Treasury, and that the President had no authority to direct or over-rule him in

${ }^{23}$ Memoirs of John Quincy Adams, VI, 439.

${ }^{23}$ Memoirs of John Quincy Adams, VII, 82, 347.

${ }^{24}$ Jackson MSS., 1833, March. 
the performance of his duties; furthermore, he advanced strong objections to the removal. General Cass, the Secretary of War, declined to give an opinion. Secretary Woodbury of the Navy and Postmaster-General Barry approved the removal project in a general way. By Taney, the Attorney-General, it was very strongly favored, Jackson's support, however, was materially diminished by a second opinion, taken at the close of April. Taney continued strongly to favor the removal; but Woodbury retracted to the extent of disapproving any early or sudden transfer, and Barry definitely advised delay, until the assembling of Congress. Most important of all, McLane stood immovably by his old position.

The President undaunted, and favored by the circumstance that Congress was not in session, now proceeded to reconstruct the Cabinet, cautiously at first. McLane, whose antecedents were Federalist, was too valuable a recruit to offend; and was transferred from the Treasury to the State Department, where a vacancy was afforded by Livingston's preference for a foreign mission. It was even suspected that he influenced the selection of his successor in the Treasury, William J. Duane of Pennsylvania, after the peculiar issue of that appointment had convicted Jackson of short-sightedness; but this was authoritatively denied. ${ }^{25}$ The new incumbent of the Treasury was known to entertain Constitutional objections to the Bank. But upon the question of removing the deposits, he had not declared himself; and when called upon to be the agent of such a measure, asserted the same opinions as his predecessor. To these he firmly adhered during a brisk correspondence that ensued between President, Secretary, and Attorney-General. On September 23, the division within the Executive culminated in the abrupt dismissal of the Secretary of the Treasury, and the transfer of the AttorneyGeneral to that post. Jackson had already communicated to the Cabinet on the I8th, his final decision to effect the removal of the deposits. The paper which he presented on the occasion closes with a very characteristic utterance: "The President again repeats that he begs his Cabinet to consider the proposed measure as his own,

${ }^{25}$ Autobiography of Amos Kendall, 377 ; Jackson MSS., Van Buren to Jackson, September I8, I833. 
in the support of which he shall require no one of them to make a sacrifice of opinion or principle. The responsibility every way is and shall be his." With Taney for official director, and Amos Kendall for the immediate agent, the work of removal was accomplished.

But the President's triumph was not complete, until his assumption of the authority reposed in the Secretary of the Treasury had been sustained by Congress. And the session of $1833^{-} 34$ was practically consumed with the subject. The House of Representatives, overcoming its proverbial ticklishness about matters financial, with its devotion to Jackson, upheld his course with a series of resolutions against the recharter of the Bank of the United States and the restoration of the Government deposits, which action brought some prominence to James K. Polk, a Democrat member from Tennessee, who was afterwards to make large political capital out of the Jackson tradition.

In the Senate, Jackson was in the minority, with Clay for opposition leader. The President suffered a formal defeat in the passage of the famous resolutions of censure, afterwards expunged. But, for practical purposes, the deadlock between the two Houses of Congress operated as their united support would have done. The burden of Clay's argument for the President's censure, it should be noted, was the exemption of the Treasury, by Constitutional and statutory provision, from Executive interference. Jackson, who answered in a written protest, did not meet him squarely upon that point; but promulgated a broad theory of the Executive power in more general terms. ${ }^{28}$ Proposals to restrict the powers that the President was abusing, by amendment to the Constitution, were an incident of the controversy.

It is illuminating to couple with this episode a controversy of much humbler proportions over the nature of the Post Office, which was drawn into a case that was heard by the Supreme Court of the United States during Van Buren's presidency. New importance had attached to the Post Office establishment within a few years. Jackson had

${ }^{20}$ The Congressional Globe, I833-I834, pp. 54-57; Richardson, Messages and Papers of the Presidents, III, 79, 84 ; See Chapter, The Cabinet and the President. Infra. 
called its head into the Cabinet; and in 1836 , July 2, the law had ordered that certain postmasters be appointed by the President with the concurrence of the Senate. In its earlier years, it had been a small concern, rather a bureau under the Treasury than a separate branch of administration, which relation we take to have been due in the first place to Hamilton's aggressiveness, and afterwards to a statutory provision that the head of the General Post Office should report to the Secretary of the Treasury. President Monroe had instituted the fashion of calling upon the Postmater-General for an Annual Report to be submitted to Congress, along with others, at the time when the President's Message was transmitted. ${ }^{27}$ The Post Office had been established under the Constitution, not by a permanent statute-it operates at the present time, under an act of such recent date as June $8,1872-$, but by a series of temporary provisions, enacted for short intervals. The original one of these, September 22, I789, had expressly stated that the Postmaster-General " should be subject to the direction of the President of the United States in performing the duties of his office." ${ }^{28}$ But the provision dropped out of the succeedings acts.

While the great quarrel between the Executive and the Treasury was still in men's minds, an action was brought in the Circuit Court of the United States for the District of Columbia, to compel Amos Kendall, the Postmaster-General, to complete, according to a special act passed by Congress in favor of the complainants, certain contracts entered into by his predecessor. The Court issued a writ of mandamus; whereupon the case was appealed. The argument before the Supreme Court to sustain the mandamus opened up the whole subject of the nature of the Executive; and maintained that the Post Office was an institution apart from Executive control. The Court declined to concern itself with such far-reaching questions, beyond expressing disapproval that they had been raised. But it sustained the mandamus by another line of reasoning. ${ }^{20}$ This disposition to circumscribe the President's field of authority was faintly

${ }^{27}$ Memoirs of John Quincy Adams, VII, 54I.

${ }^{23}$ Statutes at Large, I, 70.

${ }^{29}$ I2 Peters 570, 6ro. 
heard again in Tyler's administration, when an amendment to the Constitution was proposed that should make both the Treasury and the Post Office independent of his control. ${ }^{30}$

With the Senate keeping up a fierce cannonade against his use of the appointing power, Jackson did not venture to nominate the Cabinet officers of the vacation of 1833 for confirmation until the session was almost at an end. June 24, 1834, he communicated the appointment of Roger B. Taney as Secretary of the Treasury; and it was rejected by a party vote of 28 to I8. The vacancy in the AttorneyGeneralship, arising from Taney's promotion, had been filled by the appointment of Benjamin F. Butler of New York, a selection of Van Buren's; and this was confirmed. On June 27, John Forsyth, Senator from Georgia, and formerly Minister to Spain, was nominated to be Secretary of State, and Levi Woodbury, head of the Navy Department, to be Secretary of the Treasury; both of these were confirmed. One day later, the vacancy in the Navy Department was filled by the appointment of Mahlon Dickerson, Senator from New Jersey. A year later, a Cabinet change of peculiar interest occurred, when Barry of the Post-Office Department gave place to Amos Kendall of "Kitchen Cabinet" fame. Inasmuch as Kendall had requested that his installation be deferred until Congress had adjourned, that he might have some months of service to recommend him for confirmation, the change occurred in May 1835. The next session, however, brought Jackson a majority in the Senate; and, when his favorite was nominated, December 28, the opposition asserted itself only by a delay of two weeks and a small dissenting vote.

In ability, Jackson's last Cabinet was as indifferent as his first; but the personal relations were vastly improved. He had been in the habit of asserting that he would "have harmony above everything else;" and during the last two years of his administration, his maxim lost its unconscious irony.

Politically, Jackson's triumphs worked to the advantage of the nascent Whig party. The full effect was deferred until Van Buren had succeeded his master in the Presidency, when a most untimely

\footnotetext{
${ }^{30}$ Ames, Amendments to the Constitution, 351.
} 
financial panic branded the fiscal innovations with failure in the minds of the people. But the rifts that cleft the Democrat party asunder in 1840 were first opened by the Bank controversy. The case of mugwumpery, that was pregnant with the greatest consequences to political history was that of John Tyler, Senator from Virginia, who, though not a Nullifier, separated from Jackson on the "Force Bill" of I833, and was further disaffected by the removal of the deposits, though he had held the Bank of the United States to be unconstitutional. Almost immediately, Tyler was marked as a suitable man for second place upon an anti-Jackson presidential ticket, that those States that supported Judge Hugh L. White against Van Buren made him their candidate for the Vice-Presidency in 1836. Furthermore, Louis McLane was morally dismissed from the State Department by the summary expulsion of Duane from the Treasury, and the prosecution of the removal project to the finish; and though he had been the incumbent of the English mission and of the two ranking Cabinet offices under Jackson, he was numbered with the throng of bolting Democrats that helped to elect William Henry Harrison to the Presidency in 1840. 

President.

MARTIN VAN BUREN, New York.

VICE-PRESIDENT.

RICHARD M. JOHNSON, Kentucky.

March 4, I837, to March 4, I84r.

SeCRETARy of State.

JoHn Forsyth, of Georgia; continued from last Administration.

J. L. MARTin (Chief Clerk), ad interim, March 4, i84r.

Secretary of the Treasury.

Levr Woodbury, of New Hampshire; continued from last Administration.

McCunntock Young (Chief Clerk), ad interim, March 4, I841.

SeCRETARY OF WAR.

Benjamin F. Butler, of New York; continued from last Administration. Joel R. Poinsett, of South Carolina, March 7, 1837.

AtTORNEY-General.

Benjamin F. Butler, of New York; continued from last Administration. Felix Grundy, of Tennessee, July 5, I838, to take effect September I, 1838 . Henry D. Galpin, of Pennsylvania, January iI, I840.

\section{Postmaster-General.}

Amos Kendall, of Kentucky; continued from last Administration. JoHN M. NiLes, of Connecticut, May 19, I840.

SeCretary of the Navy.

MAhlon Dickerson, of New Jersey; continued from last Administration. James K. Paulding, of New York, June 25, 1838. 



\section{VAN BUREN.}

It had been given out that Van Buren's administration would be a continuation of Jackson's, and was taken for granted that the existing Cabinet would be retained. However, General Cass, who had not been efficient as a Department Head, had quitted the War Office for the French Mission, and the vacancy had been left for the in-coming President to fill. Some instructive advice was given about the matter by Judge Richard E. Parker of Virginia. ${ }^{1}$ In addition to reiterating Jackson's rule that presidential aspirants are ineligible to Cabinet office, it was urged that a slave-holding State must receive the vacant portfolio. Apparently, this is the earliest spoken demand for a sectional balance in the Executive. The new Secretary of War was found in the person of Joel R. Poinsett of South Carolina, who had been a Representative in Congress, and Minister to Mexico. A large factor in this selection was the service that Poinsett had rendered Jackson in dealing with Nullification.

Van Buren did not adopt the fashion, that had obtained during his own secretaryship, of dispensing with the Cabinet College. Within ten days after his inauguration, he held a meeting of Department Heads, when he submitted questions concerning the settlement of the North-Eastern Boundary. Soon afterwards, he prepared a Cabinet paper that he did not submit; because, as he endorsed upon it, "I decided to take the entire responsibility, and had, moreover, reason to believe that the Cabinet would be divided upon the subject." But a little later, he held a consultation at which he took opinions upon certain matters growing out of the Treasury Order of 1836 , and upon calling an extra session of Congress. ${ }^{2}$

Speaking doubtless of departmental affairs, a later member of the Executive, George Bancroft, the historian, said that Van Buren left

\footnotetext{
${ }^{1}$ Van Buren MSS., R. E. Parker to Van Buren, February 7, 1837.

${ }^{2}$ Van Buren MSS., Cabinet Papers, March 14, 24, May-.
} 
his Secretaries for three years to act much upon their own responsibility, and that his course was full of reverses; but that in his fourth year, he made himself the head and centre, and the administration closed admirably. ${ }^{3}$

But Van Buren had stronger and equally trusted advisers outside of his official household. Judge Parker of Virginia continued to be a confidential correspondent. Silas Wright of New York, who had charge of the Independent Treasury measure in the Senate, stood high in favor. And Chief Justice Taney, on one occasion, almost did an official counsellor's part, by submitting, in great confidence, a long written opinion on the plan for an Independent Treasury. ${ }^{4}$ But the real Mentor was Jackson, who in retirement at the Hermitage, played the role of sage to Van Buren's administration, even more perfectly than Jefferson had done to Madison's.

To the changes of personnel in this Cabinet, special interest attaches, both for personal reasons and the enunciation of new principles. About the middle of Van Buren's term of office, Secretary Woodbury, who had assumed the Treasury portfolio between five and six years before, applied the rotation principle to himself, and volunteered to resign. There was, he said, a general feeling in the East, in favor of rotation in office, and short terms of service, which he was reluctant to disregard, for fear of arousing dissatisfaction among his friends. Accordingly he proposed to give way to some other eastern democrat, and relieve the administration of a cause of "constant and virulent assault." " Woodbury was not permitted to resign. But the rotation principle was applied to the Cabinet within a very few years.

In the summer of 1838 , changes occurred in the Attorney-Generalship and the Navy. Desiring to keep one of the portfolios in the Empire State, Van Buren tendered the Navy to Washington Irving, observing in the choice of a literary man, a fashion that Jackson had introduced in the diplomatic and consular services. Irving declined in words that showed that Cabinet office would be persecution to his

\footnotetext{
${ }^{3}$ M. A. DeWolfe Howe, Life and Letters of George Bancroft, II, 225.

'Van Buren MSS., Taney to Van Buren, July 20, 1837.

${ }^{5}$ Van Buren MSS., Woodbury to Van Buren, September 8, I839.
} 
sensitive temperament, at the same time professing a deep fascination with naval affairs. ${ }^{\circ}$ The Department was filled by the appointment of James K. Paulding, who also was known chiefly as a man of letters, but had held office at the port of New York, and had shown some aptitude for politics.

In the resignation of Benjamin F. Butler from the office of Attorney-General, the administration lost a strong man, and one who had to be taken account of in dealing with New York, when the Democrats returned to power under Polk. For some time, Mr. Butler dicharged the duties of Attorney-General as a non-resident, after the fashion of earlier years. The office, after being declined by Judge Parker of Virginia, was accepted by Felix Grundy of Tennessee, who, however, resumed his seat in the Senate a year and a half later. James Buchanan of Pennsylvania was then given an opportunity to quit the Senate for the Attorney-Generalship, but considered the inducement too small; whereupon Henry D. Gilpin of Pennsylvania, previously Solicitor of the Treasury, succeeded Judge Grundy.

At the approach of the presidential campaign of 1840 , there was introduced the oft revived fashion of the retirement of the Postmaster-General. For Kendall found his health inadequate to directing a Department and at the same time serving as chief campaign manager. Jackson, while regretting his favorite's retirement, in a letter to the President, cheerfully remarked that he would be more useful to their cause, where he had gone. And the Globe announced in an extra that Mr. Amos Kendall would write its editorials for a time.

The increased importance that had attached to the political side of an administration, since Jacksonism had rooted up the earlier precedents, is expressed in a most unkind aspersion cast upon the Van Buren Cabinet, by a fellow Democrat, at the next presidential election. "I saw that Van Buren had made a bad beginning. Forsyth was too selfish to love any man, and Woodbury ditto. Old Dickerson was an imbecile. Kendall's vanity and self-consequence had already begun to act fatally upon that mass of individuals attached to and affiliated with his department. The fatal secret was

- Van Buren MSS., Washington Irving to Van Buren, April 30, 1838. 
at once disclosed that these men did not love Van and that they only regarded themselves as loci tenentes who were entitled to their pay." " And a less caustic critic said that if Van Buren had changed his Cabinet, and selected young, talented, and ambitious men, he would never have been turned out, but that he had old men about him, who loved ease as well as himself. ${ }^{8}$

That the Van Buren Cabinet was inert, and without strong following is a true characterization. It forms one of the neutral spots in the history of administrations.

${ }^{7}$ Polk MSS., A. Balch to Polk, December 2, I844.

${ }^{8}$ Curtis, Life of James Buchanan, I, 609, F. W. Pickens to Buchanan, July 5, I846. 
President.

WILLIAM HENRY HARRISON, Ohio. (Died April 4, I84I.)

VICE-PRESIDENT.

JOHN TYLER, Virginia.

March 4, I84I, to April 4, I84I.

Secretary of State.

J. L. Martin (Chief Clerk), ad interim, March 4, I84I.

Daniel Webster, of Massachusetts, March 5, I84I.

SeCRetary of the Treasury.

McClintock Young (Chief Clerk), ad interim, March 4, I84I.

Thomas Ewing, of Ohio, March 5, I84i.

Secretary of War.

JoHn BeLL, of Tennessee, March 5, I84I.

AtTORNEY-GENERAL.

John J. Crittenden, of Kentucky, March 5, i841.

Postmaster-General.

Selah R. Hobbie, of New York (First Assistant Postmaster-General), ad interim, March 4, 184r.

Francis Granger, of New York, March 6, I84I.

Secretary of the Navy.

George E. BAdGer, of North Carolina, March 5, I84r. 



\section{WILLIAM HENRY HARRISON.}

The administration of William Henry Harrison, lasting, as it did, but a single month, is important only as an introduction to the extraordinary chapter of Cabinet history that is associated with the name of John Tyler. And it is in its relations to Henry Clay, Tyler's great antagonist, that it should be viewed.

General Harrison was a presidential candidate, whom the Whig managers, especially Thurlow Weed, had preferred for his popular military career and his negative record in public life over the statesmen of their party. Inasmuch as his congressional career antedated the Jackson era, his position on current issues was somewhat ill defined. But he had been known to express his approval of Clay. Elected to the Presidency at an advanced age, he announced that he would not stand for another term of office, conformably to the single term rule, which the Whigs were promulgating at the time. With regard to forming an administration, he inclined more to the ideas of the early Republicans than to those of Jackson; and singled out for members of his official household, regardless of their rivalries, the statesmen who had stood in the front ranks of the Government opposition during the past twelve years.

The State portfolio seemed to appertain to Clay, both by his acknowledged leadership in the party, and his previous incumbency; while Webster, thus relegated to second place, was marked for the Treasury by his chairmanship of the Senate Committee of Finance.

Approaching with great tact, the chieftain from whom he had taken the nomination, Harrison brought about an interview at Franfort, Kentucky, about a month after the election. He there made him an officer of the State Department, to find that the headship of the Cabinet had yielded its attractions to the leadership of the Senate. Clay, however, urged the appointment of Webster, declaring that no Whig President could overlook him, not even himself, had he been in that position. ${ }^{2}$

${ }^{1}$ Works of Clay, Ed. 1904, V, 446; Clay to Francis Brooke, December 8, I840. 
On December I, a choice of the State and Treasury Departments was tendered to the statesman from Massachusetts, with the information that the former had already been declined by his rival, and that the latter was originally intended for himself. On the rith, Webster accepted the Department of State, explaining that he was not attracted to the detail of the Treasury, and that the great matters of that department would come before all the members of the administration, as Cabinet questions. ${ }^{2}$

At this point, Clay's influence seems to have ceased; for persons were not lacking to make the President-elect sensitive to dictation. Yet it must have been as a proxy for the party leader that John J. Crittenden, the junior Senator from Kentucky, was selected to be Attorney-General.

With regard to the Treasury, Clay's views were positively set at naught. Thomas Ewing of Ohio had originally been slated for the Postmaster-Generalship, and the chieftain had not objected to assigning that office to the North-West. But influences from the North availed to shift Ewing's name to the Treasury. For this portfolio, Clay had selected John M. Clayton of Delaware, as a borderer known to be acceptable to the South for the part he had taken in passing the Compromise Tariff of 1833. Should Pennsylvania prevail, however,-and she was advocating John Sergeant, one of her Representatives, for the Treasury,-Clay would at least have the Navy Department for Clayton. ${ }^{3}$ But it was Ewing that became Secretary of the Treasury, while Delaware's ex-Senator received nothing.

Two of the Cabinet appointments reflect particularly the heterogeneousness of the body of voters that had made Harrison President. Representative John Bell of Tennessee, who had been a Jackson Democrat, and in the disorganized opposition of 1836 , had been a leading supporter of White and Tyler, was selected for the War Department. Incidentally to the gossip in Congressional circles, Mr. Bell himself had written to a friend that Webster was objecting to his appointment, for fear that he would make too much of a Clay

${ }^{2}$ Private Correspondence of Daniel Webster, II, 90, 93; Harrison to Webster, December I, I840; Webster to Harrison, December II, I840.

${ }^{3}$ Clayton MSS., Clay to Clayton, December I7, 1840. 
man, and that Clay was not enthusiastic for it, for fear that he would not make enough of one.

The New York member was Francis Granger. A seat was previously offered to Nathaniel $P$. Tallmadge, one of the many recruits from Democrat ranks. But Tallmadge had just been elected by his new party to continue in his old place in the Senate, and the circumstance held him to his seat there the more firmly. Francis Granger had been an Anti-Mason, and was now beginning to be classed with the abolitionists. In 1836 , he had been the candidate for the Vice-Presidency, in most of the States that had supported General Harrison for the first place, and on the Massachusetts ticket, his name had been coupled with Webster's. He became Postmaster-General in Harrison's Cabinet, being the son of Gideon Granger, who enjoyed a long and somewhat notorious incumbency of the same office, without a Cabinet seat, under Jefferson and Madison.

The Navy portfolio fell to the South by the sectional rule, and the particular man was left to the choice of the Congressional delegations. One of the names proposed was that of William C. Preston, Senator from South Carolina. And, inasmuch as the expected Bank measure had an uncertain majority in the Senate, a story went forth among its opponents, that it was the fear that Preston's resignation would cause a tie, and throw the casting vote to Vice-President Tyler, that prevented his appointment. George Badger of North Carolina was finally selected to be Secretary of the Navy.

The factional forecast for the administration was that Clay, who already had an alter ego in Crittenden, would also gain control over Ewing, Bell, and Badger, while Granger followed the lead of Webster. But Clay had not achieved his triumph, when Harrison died. He had, in fact, suffered much embarrassment from the knowledge that political enemies were putting the President upon his guard, in the apportionment of offices, the principal business accomplished. The delicate subject had come up between the two both in conversation and correspondence. It is a very pertinent question, whether the uncertainty of Clay's ascendency in this administration does not throw much light upon the strange course of the next President towards his inherited Cabinet. 


\section{President. \\ JOHN TYLER, Virginia. \\ President Pro Tempore of the Senate. \\ SAMUEL L. SOUTHARD, New Jersey. \\ WILLIAM P. MANGUM, North Carolina.}

April 4, I84I, to March 4, I845.

Secretary of State.

Daniel Webster, of Massachusetts; continued from Harrison's Administration.

Hugh S. Legaré, of South Carolina (Attorney-General), ad interim, May 9, I843.

William S. Derrick (Chief Clerk), ad interim, June 20, I843.

Aber P. Upshur, of Virginia (Secretary of the Navy), ad interim, June 24, I843.

ABer P. UPSHUR, of Virginia, July 24, 1843.

John Nelson, of Maryland (Attorney-General), ad interim, February 29, I844.

John C. Calmoun, of South Carolina, March 6, I844.

Secretary of the Treasury.

Thomas Ewing, of Ohio; continued from Harrison's Administration.

McClintock Young (Chief Clerk), ad interim, September 13, I84I.

Walter Forward, of Pennsylvania, September I3, I84I.

McCuntock Young (Chief Clerk), ad interim, March I, I843.

- John C. SPENCER, of New York, March 3, 1843.

McClintock Young (Chief Clerk), ad interim, May 2, I844.

George M. BibB, of Kentucky, June I5, 1844.

SeCretary of War.

JoHN BeLl, of Tennessee; continued from Harrison's Administration.

Albert M. LEA, of Maryland (Chief Clerk), ad interim, September 12, I84I. JoHN C. SPENCER, of New York, October I2, I84I.

JAmes M. Porter, of Pennsylvania, March 8, I843.

William Wilkins, of Pennsylvania, February 15, 1844. 
Attorney-General.

John J. Crittenden, of Kentucky; continued from Harrison's Administration. Hugh S. Legaré, of South Carolina, September I3, I84I.

JoHN NELSON, of Maryland, July I, 1843 .

\section{Postmaster-General.}

Francis Granger, of New York; continued from Harrison's Administration. Charles A. Wickliffe, of Kentucky, September I3, i84I.

SeLAH R. HobBie, of New York (First Assistant Postmaster-General), ad interim, September I4, I84I.

SeCretary of the Navy.

GEORge E. BADGER, of North Carolina; continued from Harrison's Administration.

John D. Simms (Chief Clerk), ad interim, September I2, I84I.

Abel P. Upshur, of Virginia, September 13, 1841.

David Henshaw, of Massachusetts, July 24, I843.

Thomas W. Gilmer, of Virginia, February 15, 1844.

Lewis WarRington (Captain, U. S. N.), ad interim, February 29, 1844. John Y. MASON. of Virginia, March I4, I844. 


\section{TYLER.}

More than ordinary institutional significance attaches to the Tyler administration, in that it put to the test, and vindicated, the authority of accidental Presidents over the Cabinet officers. This was accomplished, moreover, by means of a manoeuvre on the President's part, that of itself gives the administration a unique interest.

The summoning of a special session of Congress, by President Harrison, agreeably to the wishes of Clay, to take account of the fiscal situation, the past record of Mr. Tyler, as a States-Rights' Democrat on the Bank question, and his assumption of the duties of President, before the special session had convened, assured a crisis from the outset.

This famous controversy needs to be reviewed only in outline. April 9, I84I, President Tyler published an Inaugural Address, in which he promised to sanction any Constitutional measure for the restoration of a sound circulating medium; and referred to the ever glorious example of the fathers of the great Republican school as the authorities upon whom he should base his opinions. ${ }^{1}$ This was followed, June I, by the Special Session Message, which discussed the fiscal methods previously employed by the Government, with the objections to each, and pledged the President's concurrence in some system to be devised by Congress, reserving to the President the ultimate power to reject any measure which conflicted with the Constitution, or jeopardized the prosperity of the country. ${ }^{2}$ On the next day, the report from the Treasury by Secretary Ewing-for Tyler had retained the Harrison Cabinet throughout-went so far as to recommend the restoration of the Bank of the United States, qualifying that proposition, however, with the stipulation that such institution must be so "conceived in principle and guarded in its

\footnotetext{
${ }^{1}$ Richardson, Messages and Papers of the Presidents, IV, 39.

${ }^{2}$ Richardson, Messages and Papers of the Presidents, IV, 40.
} 
details" as to remove the scruples touching the question of Constitutional power, which some wise and patriotic statesmen were known to entertain. ${ }^{3}$ June 7, the Treasury Department received a call from the Senate for a definite fiscal plan, this action on the part of the Upper House being pursuant to the adoption of a series of resolutions presented by Clay as an outline of the business before the session." June I2, a special report was submitted by Secretary Ewing in response to the call. This document covered a bill for the incorporation of a fiscal bank, to be situated in the District of Columbia, and to be dependent upon the will of the States for permission to establish branches. The measure had been prepared after consultation between the Secretary of the Treasury and the President, as to those features which involved Mr. Tyler's views concerning Federal corporations operating over the States. June 2I, the select committee, created to take the measure in charge, with Clay for chairman, reported in its stead, a bill to incorporate a bank exercising such powers as had been granted in the charter that Jackson vetoed nearly ten years before, and calculated to make a direct issue with the doubtful whiggism of Tyler. ${ }^{5}$ A series of attempts were made to graft onto this certain features of the bill that the committee had pigeon-holed, and it bore a semblance of recognition of the "states-rights" view of certain points, when it reached the President. On August I6, came the President's veto."

A procedure was now resorted to, to fix up an understanding between President Tyler and Congress that was most extraordinary when compared with present modes of communication. The President refused to hold personal interviews with members of Congress, but allowed the Secretaries to act as a go-between. He all along avowed the greatest consideration for a peculiar sensitiveness in Congress about dictation by the President. The Whigs themselves had become responsible for an exaggerated form of this doctrine, in their quarrel with Jackson; and Harrison had proclaimed it in his In-

${ }^{3}$ Senate Documents, First Session, Twenty-Seventh Congress.

${ }^{4}$ Senate Documents, First Session, Twenty-Seventh Congress.

${ }^{5}$ Senate Documents, First Session, Twenty-Seventh Congress.

'Richardson, Messages and Papers of the Presidents, IV, 63. 
augural Address. ${ }^{7}$ President Tyler held a Cabinet meeting August I8. And the understanding was reached that he would sanction a fiscal institution dealing in foreign exchanges, but not in local discounts, the former being defensible under the power of Congress to regulate foreign and inter-State commerce. And furthermore, the two leading Secretaries, Webster of the State Department and Ewing of the Treasury, were delegated to confer with members of Congress with reference to introducing a new measure. It so happened that during the struggle over the charter drawn by Clay, a bill had been put into the House of Representatives that followed the plan from the Treasury more closely. This was now revised; and the name "Fiscal Corporation " adopted, instead of "Fiscal Bank." The measure was not allowed to go through Clay's hands in the Senate, but was given to a new committee. President Tyler received the bill on September 5 , and vetoed it on the 9th, the main objection being that the power to deal in outside exchanges was so defined as to make room for local discounts. ${ }^{8}$

The question was now fully before the Whigs, what leader they would acknowledge. Two days after the veto, four members of the Cabinet, Ewing, Crittenden, Bell and Badger, resigned, one after the other. The adjournment of Congress being at hand, successors were at once nominated and confirmed. The resignation of Granger followed. But Webster clung to his portfolio. Before the adjournment, a caucus of Whigs adopted an address to the party, both repudiating Tyler, and proposing to restrict the powers of the Presidential office. The appointment and removal of the Secretary of the Treasury should be put into the hands of Congress, and the veto power limited. At the next session, the declaration bore results in the form of resolutions to amend the Constitution, which the anti-Tyler Whigs had not a large enough majority to carry.

The significance of this passage in the history of the Executive does not depend upon the question, whether the President dealt with the Cabinet by fair means or foul. And yet it is interesting to place

${ }^{7}$ Richardson, Messages and Papers of the Presidents, IV, 9.

${ }^{8}$ Richardson, Messages and Papers of the Presidents, IV, 68.

-Ames, Proposed Amendments to the Constitution, 135. 
over against each other the two sides of the case, set forth in the letters of the Cabinet officers, on the one hand, ${ }^{10}$ and, on the other, in the Biography-Apology of President Tyler by his son, Doctor Lyon G. Tyler. ${ }^{11}$

The gravamen of the offence charged by the retiring Secretaries, was first, that they had been the victims of a game of fast and ioose, and, second, that the President had misused the veto power. Mr. Ewing, as Secretary of the Treasury, had been the most directly exposed to this unconventional treatment. In his letter of resignation, he passed over everything relating to the first bill with the concession that the Clay measure was too much of a challenge to the President. But he charged that, in the management of the Fiscal Corporation Act, he had been treated with " personal indignity." He had been requested to communicate with members of Congress; Congress had acted upon the faith of such communication; and the measure had been vetoed without word of apology. The Apologist for Mr. Tyler, on the other hand, makes a strong point of the plea that the plan from the Treasury was the Secretary's plan, not the President's. And he enters the second claim, that the President had not committed himself to the Fiscal Corporation Act. Granted that he had delegated his two principal Secretaries to assist in getting a measure before Congress, he had reserved fair means of retreat. ${ }^{12}$

The most satisfactory explanation of President Tyler's course is that it was a make-shift, perhaps not a consciously pre-conceived one, to sift the Cabinet, and to test its members, as to which master they would serve. Mr. Tyler had succeeded to the Presidency with a most uncertain following, as is shown by the very manner and purpose of his nomination for the Vice-Presidency. ${ }^{13}$ No one doubts that he desired a second term of office. And he was confronted with the task of building up a party. The immediate dismissal of the Harrison Secretaries would have been impolitic, because Cabinets had

\footnotetext{
${ }^{10}$ Niles Register, LXI, 33-35, 53, 54.

${ }^{11}$ Letters and Times of the Tylers, II, 29-I21.

${ }^{12}$ Letters and Times of the Tylers, II, 82, 86; Niles Register, LXI, 54.

${ }^{13}$ Thurlow Weed Barnes, Life of Thurlow Weed, II, 77.
} 
hitherto changed with the party and not with the President. Furthermore, under the existing alignment of factions, their political allegiance was not fully determined. The Cabinet rupture gave the President the full possession of the Executive and the support of the most important Secretary.

One element in the estrangement between the President and Secretaries was the fact that $\mathrm{Mr}$. Tyler had immediately surrounded himself with a "Kitchen Cabinet," composed of a coterie of political and personal friends from his own State. Perhaps with too much consciousness that the sceptre had returned to Virginia, this group made itself so conspicuous as to arouse the jealousy of the official Cabinet. Henry A. Wise, Thomas H. Gilmer, and Francis Mallory, all Representatives, were of the number; also W. C. Rives, in the Senate. Outside of Congress, there were Judge Beverly Tucker, and Thomas R. Dew, President of William and Mary College. The sarcastic references to the "Virginia schoolmasters" in the correspondence of the Clayites were probably inspired by the latter gentleman's profession.

With his Constitutional advisers, Tyler preserved the outward forms of formal intercourse, observing Wednesday as Cabinet day; but some of his important steps he did not confide to them. The " Kitchen Cabinet," on the other hand, were in such close confidence that they were regarded as his inspirers. Indeed Wise would have it appear that he knew the President's purposes better than the President did himself.

Tyler's newspaper organ, the Madisonian, set up the cry that the President had been deserted in a most trying hour $;^{14}$ and Lyon G. Tyler has seen fit to echo this. ${ }^{25}$ It is true that the resignations were planned under Clay's inspiration, the occasion being a gathering at the house of Secretary Badger, on the evening of the day of the second veto. ${ }^{18}$ Webster obtained the consent of the Massachusetts delegation, to his remaining in office, the prospect of his being able to settle the North-Eastern Boundary question being urged in justifica-

${ }^{14}$ Van Tyne, Letters of Daniel Webster, 238.

${ }^{15}$ Letters and Times of the Tylers, II, Iro.

${ }^{10}$ Webster's Private Correspondence, II, I Io. 
tion. ${ }^{17}$ A report that Granger would also remain was spread abroad on the Sunday that intervened between the other resignations and his. And some mystery attached to the resignation of Bell, whose allegiance to Clay had also been doubtful. It was reported that he submitted to pressure that the great chieftain was able to exert upon the Congressmen from Tennessee. His letter of resignation was hardly that of a man acting upon his own convictions. But indications are not lacking that the President was making ready to fill up the gaps so soon as they should occur. The promptness with which he submitted a new list of appointments indicates that he was not unprepared. More convincing proof is gleaned from the correspondence of interested parties. About ten days before the second veto, Reverdy Johnson of Maryland, afterwards a member of the Taylor Cabinet, had written to Crittenden, the Attorney-General, that an agent of the President's had appeared at Baltimore, and had been in conference with Judge Abel P. Upshur and other gentlemen, and that it was suspected that a new Cabinet was being formed. ${ }^{18}$ Furthermore, Henry A. Wise had written, on August 29, just as the Fiscal Corporation Bill was going to the Senate: "We are on the eve of a Cabinet rupture. With some of them we want to part friendly. We can part friendly with Webster by sending him to England. Let us for God's sake get rid of him on the best terms we can. ${ }^{10}$ Wise's characteristic heat of expression is seen here. Tyler did not wish to part company with Webster at this time. He declared afterwards, however, that he could have obtained a new Secretary of State, and an able one, if Webster also had gone after Clay, which we take to be an allusion to Judge Upshur, who became Secretary of the Navy at first, but was afterwards elevated to the State Department. ${ }^{20}$ Years after the event, Wise wrote that the rest of the Cabinet, except Webster, retired, "knowing full well that, if they had not bowed themselves out, they would have been shown the door." ${ }^{21}$ But it is

\footnotetext{
${ }^{17}$ Memoirs of John Quincy Adams, XI, I3, I4.

${ }^{18}$ Coleman, Life of J. J. Crittenden, I, I60.

${ }^{18}$ Letters and Times of the Tylers, II, 90.

${ }^{20}$ Letters and Times of the Tylers, II, 97.

${ }^{21}$ Wise, Seven Decades of the Union, 192.
} 
thoroughly consistent with Tyler's next political movements, and a very satisfactory view of the matter on all accounts, to believe that he would have retained, up to the time, when he made a radical change of policy, as many of Harrison's Secretaries as would remain with him.

The real significance of President Tyler's course lies in its tendency, when it is viewed as a Cabinet practice or a mode of Executive procedure. If Mr. Tyler was straightforward and consistent in his dealings with Mr. Ewing, he at least disavowed the President's responsibility for the policy of the Secretary of the Treasury. This was distinctly a step backward from the position reached by Jackson. And under the prevailing conception of the single responsibility of the Executive, it could not be approved. Neither could the mode of initiating legislation that Tyler resorted to have fortunate results. The relation between the Administration and Congress would be precarious indeed, if the President, even under intense pressure and in the field of his unofficial acts, authorized negotiations between the two branches of Government, and at the same time refused to commit himself to their support.

After the rupture with Clay, the Tyler Cabinet owes its interest entirely to its varying political complexion. With the Democrats disintegrated, and the Whigs unamalgamated, the factions were never better arranged for new combinations than in $\mathrm{I} 84 \mathrm{I}$; and predictions were rife as to what these would be. So early as April 20, John Quincy Adams confided to his Diary that there would be an alliance between Tyler and Webster. ${ }^{22}$ And Silas Wright, who represented the Van Buren Democrats, foresaw the same arrangement. ${ }^{23}$ But it does not appear that the Clay men were especially apprehensive of such an issue. ${ }^{24}$ On June I I, while the Senate awaited the fiscal plan from the Treasury, Clay expressed the contrary fear that Tyler would throw himself upon Calhoun and Duff Green, and desert the

${ }^{22}$ Memoirs of John Quincy Adams, X, 465.

${ }^{23}$ Van Buren MSS., Silas Wright to Van Buren, July 10, and August 22.

${ }^{24}$ Coleman, Life of J. J. Crittenden, I, 161, 165; R. P. Letcher to Crittenden, September 3, I84I; Crittenden to Letcher, September II, I84I. 
Whigs entirely. ${ }^{25}$ Calhoun had been somewhat of an Ismaelite, after his rupture with Jackson; but had concentrated his forces upon the Nullification issue. But Democrats of no shade or faction promised Tyler anything more than to sustain him in carrying out their principles. Politically he would have to give the surest pledges, before he could be received back into fellowship.

The first group of Cabinet appointments was made entirely from the ranks of the hybrid-Whigs. A Secretary of the Treasury was secured by promoting Walter $\mathrm{H}$. Forward of Pennsylvania, whom Harrison had made Comptroller. The Attorney-General, Hugh S. Legare of South Carolina, and the Secretary of the Navy, Abel P. Upshur of Virginia, were Tyler's personal friends. Charles A. Wickliffe of Kentucky, who was appointed to the PostmasterGeneralship, appears to have been named for Cabinet office, before it was assured that Harrison would approach Clay. For Secretary of War, John McLean of Ohio, Postmaster-General of the later Republican administrations, was appointed; but refused to resign from the Supreme Bench. A mild Whig from New York was then sought in the person of John C. Spencer, who was Secretary of State, with William H. Seward in the Governor's chair. Thurlow Weed gives an interesting account of a conference on the subject of Spencer's acceptance of a place in Tyler's service. ${ }^{26} \mathrm{Mr}$. Spencer expressed the hope that with a seat in the Cabinet, he might bridge over the differences between the President and the Empire Whigs; but his friends, who knew his political eccentricities, did not doubt, that, once seated he would zealously espouse Tyler's cause. This Cabinet was retained so long as the administration measures preserved a semi-Whig character.

In the winter of $1842-43$, the President sprang an issue that reshaped parties by taking up the annexation of Texas and California. And the Cabinet changed its complexion again. Webster was no longer desirable for Secretary of State; but Caleb Cushing, of the same constituency as Webster's, would not have been out of place

${ }^{25}$ Coleman, Life of J. J. Crittenden, I, 156; Clay to Letcher.

${ }^{28}$ Autobiography of Thurlow Weed, 517. 
in councils that were leaning to the slave interest. Early in March, I843, Mr. Forward, who had proven himself the least of Ministers of Finance, ${ }^{27}$ resigned his portfolio; and Tyler nominated Cushing to be Secretary of the Treasury. But now began the series of defeats that were inflicted upon some of the President's particular friends that he nominated for Cabinet and diplomatic offices; for, although the elections had been going strongly Democratic, since Clay's humiliation, Tyler was not gaining a personal following. The manner of the Cushing appointment is most curious, in that the President submitted the nomination three times, in rapid succession, while the Senate voted it down by 27 to 19,27 to Io, and finally 29 to 2 . It has been suggested, and seems very probable, that this persistence on Tyler's part was a hint to Webster to resign; since the double representation of a State in the Cabinet was contrary to the rules of the spoils system. The vacancy in the Treasury was filled before the session expired, by promoting Secretary Spencer of the War Department.

On May 8, 1843, Webster resigned, much beset by his friends in Massachusetts to cease companying with Tyler, and coldly treated in the latter quarter as well. ${ }^{23}$

The association that now came to an end loses much of its incongruity, when Webster's later sacrifices of principle to jealousy and political interest are called to mind. And his justification in this instance was the most plausible one that he ever had to offer. On separation from his colleagues of the Harrison Cabinet, the reason that he put first was that their resignations looked too much like a combination between a Whig Cabinet and Whig Senator to annoy the President. ${ }^{29}$ And in reingratiating himself after his own resignation, he pleaded that it had been his purpose to hold Tyler as far as

${ }^{2 \pi}$ Letters and Times of the Tylers, III, I04; Caleb Cushing to Wise.

${ }^{28}$ Schouler maintains that Tyler went so far in his unconventional treatment of Webster, as to have negotiations with the Texan Commissioners, of which the Secretary of State was not informed. History of the United States, IV, 448. Footriote.

${ }^{20}$ Private Correspondence of Daniel Webster, II, IIo; Webster to Ketchum, September I0, I84I. 
possible to Whig principles and a Whig administration. But he was above all able to point to a brilliant secretaryship, in self extenuation. The complaint that he had tarried too long, after negotiating the Webster-Ashburton Treaty, which was ratified in August, I842, he met with the plea that he was obliged to remain through the next session of Congress. ${ }^{30}$ The next diplomatic achievement of the administration, the annexation of Texas, brought Tyler and Calhoun together.

But a year of Cabinet vicissitudes intervened. The President first looked to his Southern friends who were already in the administration to fill the State Department. Attorney-General Legaré was made Secretary ad interim, until his death in the summer of 1843 left two offices unprovided for. A Secretary of State was then secured by promoting Judge Upshur of the Navy Department, while the latter portfolio was assigned to New England by the appointment of David Henshaw, who had been Collector of Customs at Boston, under Jackson and Van Buren. The War Office, vacated by the transfer of Spencer to the Treasury, just as the session was expiring, had been filled after Congress adjourned by the appointment of James M. Porter of Pennsylvania. And John Nelson of Maryland was made Attorney-General to succeed Legaré.

This long list of vacation appointments caused a war with the Senate, after the fashion of some of Jackson's encounters. There were charges of connivance to bring about a vacation reconstruction, which were aggravated by the imperfect knowledge of the public about the filling of the Treasury. The appointments were communicated to the Senate very early in the session, December 6, 1843; and after a quarrel that extended over two months, Henshaw and Porter were both unseated by an overwhelming vote. William Wilkins of Pennsylvania was then appointed Secretary of War; and Thomas W. Gilmer, one of the "Kitchen Cabinet" confidants, became Secretary of the Navy.

But the Cabinet had scarcely been intact two weeks, when it was

${ }^{30}$ Coleman, Life of J. J. Crittenden, I, 204; Webster to Letcher, October 23, 1843. 
broken up by a casualty in high life. The United States vessel Princeton was making an experimental trip on Chesapeake Bay, with a party of distinguished officials on board, when the explosion of a gun resulted in the death of Secretaries Upshur and Gilmer. And another important change was necessitated a few weeks later by the retirement of Secretary Spencer from the Treasury. On the Texas question, Spencer had not been in such full accord with Tyler, as he had been during the semi-Whig period of the administration. Moreover, he had been subjected to great personal embarrassment and trial in the summer of 1843 , by the decision of the case concerning the United States brig Somers. Captain McKenzie of that vessel was exonerated for the execution at sea of a party of mutineers, one of whom was Midshipman Spencer, Secretary Spencer's son; and the Cabinet was divided in its sympathies, McKenzie, who was a Louisiana Slidell, having influential friends in the South. In the session of $1843^{-} 44$, the President made an attempt to elevate Spencer to the Supreme Bench; but this was one of the appointments that the Senate defeated.

The vacancies in the Cabinet were now filled entirely by the appointment of Southern Democrats. And, although Spencer's retirement left New York unrepresented in the administration, we have found no evidence that Tyler approached the Democrat party there, although its forth-coming division on the Texas question might have relieved the coldness with which he had been regarded at the outset. The Navy Department, vacated by Gilmer's death, was offered to James K. Polk, who declined entering the Tyler administration for its closing year, although he was out of public life at the time. ${ }^{31}$ The manner of Polk's nomination for the Presidency gives no reason to suppose that he was influenced by any preparations for the approaching Democrat National Convention. The portfolio that he declined was accepted by a personal and political friend of his, John Y. Mason of Virginia.

The predicted affiliation between Tyler and Calhoun became a reality in a curious way. Calhoun had supported Tyler's actions, in

${ }^{31}$ Letters and Times of the Tylers, III, I33; Polk to Theophilus Fisk. 
so far as they conformed to his own principles; but there had been no understanding between them. ${ }^{32}$ In 1843 , he retired from the Senate to work up a presidential propaganda for himself. But the project for the annexation of Texas, to be followed, perhaps, by the settlement of the Oregon question, aroused his deepest interest. And no less did his suitableness for that work attract the attention of the President's familiars, when the State Department was vacated by the sudden death of Upshur. But Tyler himself demurred; whereupon Wise, who had all along regarded Calhoun more kindly than he did Webster, took an unparalleled liberty. ${ }^{33} \mathrm{He}$ went to McDuffie, Senator from South Carolina, and asked whether Calhoun would accept the State portfolio. When communicated to Calhoun, the question had become an offer, and was favorably received. On being apprised of Wise's action, Tyler acceded to it, the alternative being to cast reproach upon his favorite, and offend an important political faction. However, in his letter of official notification to Calhoun, the President gave a delicate hint as to what was expected on the political side: "While your name was before the country, as a prominent candidate for the Presidency, I could not have urged this request, without committing alike an offence to yourself and many others; but now, since your friends have withdrawn your name from that exciting canvas, I feel it every way due to the country to seek to avail myself, in the administration of affairs, of your high and exalted talents." ${ }^{34}$ Calhoun, on the other side, was half-hearted about entering the administration; and raised the question, when he was first approached, whether he could not undertake the pending diplomatic business as a Commissioner, without becoming Secretary of State.

The Treasury Department was filled after Spencer's retirement by George M. Bibb of Kentucky, who had supported Calhoun at the

${ }^{32}$ Calhoun Correspondence in Annual Report of the American Historical Association, 1899, II, 5I5; Calhoun to Duff Green, August 3I, I842.

${ }^{33}$ Wise, Seven Decades of the Union, 222.

${ }^{34}$ Calhoun Correspondence in Annual Report of the American Historical Association, I899, IJ, 938.

${ }^{35}$ Annual Report of the American Historical Association, I899, II, 573. 
time of his break with Jackson, and had also stood with Tyler in his opposition to the Force Bill of 1832 . James S. Green of New Jersey, had been previously nominated, but failed to be confirmed.

After drawing his Secretaries from almost all sections of all parties, Tyler made a political failure. The attempt to make him a presidential candidate in 1844 , made by a nondescript convention of men that he had appointed to office, failed ridiculously. But he had shown himself to be the head of the Executive; and had thwarted the attempt of Congress and Cabinet to set up a regency over him. 
President.

JAMES K. POLK, Tennessee.

Vice-President. GEORGE M. DALLAS, Pennsylvania.

March 4, I845, to March 4, I849.

Secretary of State.

John C. Calmoun, of South Carolina; continued from last Administration. James Buchanan, of Pennsylvania, March, 6, 1845.

Secretary of the Treasury.

George M. Bibb, of Kentucky; continued from last Administration.

ROBERT J. WALKeR, of Mississippi, March 6, I845.

SeCretary of War.

William Wilkins, of Pennsylvania; continued from last Administration. WiLliam L. Marcy, of New York, March 6, 1845.

Attorney-General.

JOHN NeLson, of Maryland; continued from last Administration.

JoHN Y. MASON, of Virginia, March 6, I845.

Nathan Clifford, of Maine, October I7, 1846.

IsaAC TouceY, of Connecticut, June 2I, 1848.

Postmaster-General.

Charles A. Wickliffe, of Kentucky; continued from last Administration. Cave Johnson, of Tennessee, March 6, 1845.

Secretary OF THE NAvY.

JoHN Y. MASON, of Virginia; continued from last Administration.

GEORGE BANCROFT, of Massachusetts, March ro, 1845 .

JoHN Y. MASON, of Virginia, September 9, 1846. 
$\rightarrow$ 


\section{POLK.}

Cabinet making began to assume its modern complexity, and to take on its full political significance in 1844 . In the first place, the suggestion was now becoming audible that the Heads of Departments must be changed with the President. "The people want a Cabinet from James K. Polk," was one of the answers to a demand from South Carolina, and other quarters, for the retention of Calhoun as Secretary of State. In the second place, the factional problem was assuming new proportions, both because aspirants for the presidential nomination were increasing in number, and because the old parties were beginning to split up over the annexation of Texas. During the Jackson regime, the New York Democracy had been united in support of the National administration. But it was now becoming divided into the "Barnburners" and "Hunkers," the one wing being hostile to annexation, while the other was disposed to support that policy. The Pennsylvania Democrats were equally divided; though the uppermost point of difference at the time seems to have been the rivalry between Buchanan and George M. Dallas.

These divisions had been distinctly felt in the Democrat National Convention, which was held at Baltimore late in May, 1844. By publishing a letter disapproving the Texas project, ex-President Van Buren lost the nomination, which had been universally conceded to him beforehand. And James K. Polk of Tennessee received it. By way of atonement to the Empire State, and the anti-annexation element as well, Silas Wright, Van Buren's personal and political friend, was given an almost unanimous nomination for the VicePresidency. But the "Barnburners" refused to be conciliated in that way; and Mr. Wright declined the nomination, which was accordingly passed over to Pennsylvania, in the person of George M. Dallas. It remained to adjust the Cabinet to the situation if possible.

During the campaign, much capital had been made for Mr. Polk, who was not a widely known candidate, out of the Jackson tradition; 
and shortly after his election, he repaired to the Hermitage to take counsel of the old party sage. There is something striking in the spectacle of Jackson, now within a few months of his death, and truer to his old enmities than his old friendships in the presence of the new issue, assisting at the making of this Cabinet. The account of the interview which he wrote to his former editor, Frank P. Blair, on the morning that Polk departed, deals more with persons to be avoided, than with those to be sought. All aspirants to the Presidency must be excluded from the new administration, whence none of the Tyler clique, Calhoun clique, or Benton clique could be considered. "Tylerism" should be abandoned, except that the annexation of Texas should be completed as speedily as possible. The Old Dominion must not be offended; and the plan to make an entirely new administration might safely be modified to the extent of retaining John Y. Mason of that State, the existing Secretary of the Navy, on the ground that Mr. Mason was a personal friend and former college mate of Mr. Polk's. Pennsylvania, likewise, must not be offended; but the rule against presidential aspirants was likely to make trouble there. ${ }^{1} \quad$ The electoral college of Pennsylvania had recommended $\mathrm{Bu}$ chanan for the State Department, an appointment which the strict application of that rule would not permit.

What was said about Van Buren and his friends in the interview at the Hermitage, we do not know. But Polk soon entered into correspondence with them; and definitely offered the Treasury portfolio to Silas Wright who declined it, for the office of Governor of New York. As a result of the Van Buren counsels, the names of Benjamin F. Butler, formerly Attorney-General to both Jackson and Van Buren, and Azariah C. Flagg, a very prominent man in State affairs, were bracketed on the Cabinet slate, in connection with the State and Treasury Departments respectively.

But other forces were drawing both portfolios away from New York. The North-West set up a protest against placing the Treasury there; for so, it was predicted, the land offices would be filled up with Wright men to work against General Cass, who had held second place for the presidential nomination, at the recent convention, and

${ }^{1}$ Jackson MSS., Jackson to Blair, November 29, I844. 
was distinctly recognized as one of the candidates of the future. In fact there was a demand that Cass himself should receive a Cabinet portfolio; but this was quieted by his election to the Senate.

The South had a strong candidate for the Treasury in Robert J. Walker, Senator from Mississippi. Although Walker and Buchanan were alike unacceptable to Jackson, for their interest in the presidential succession, Polk was finally induced to accede to the demands for their appointment to the Treasury and State Departments respectively. The wonted anxiety of Buchanan's State about the tariff had been allayed before the election, by the publication of the famous letter to John $\mathrm{K}$. Kane of Philadelphia, wherein Polk softened his avowed free trade sentiments with the declaration that he was not opposed to a "reasonable incidental protection." 2 And it was at Walker's suggestion that this clever move had been made. ${ }^{3}$

Nothing higher than the War Office was left for New York, and that portfolio was formally tendered to Benjamin F. Butler, who declined it as being too small a gift. Failing to establish a connection with the Van Buren faction, Polk turned to the annexationists; and selected William L. Marcy, formerly a United States Senator, and lately Governor of the State, to be Secretary of War. Probably Polk had not seriously intended to attach the Van Burenites to his administration. It is thought that the offer 'of the Treasury to Silas Wright would not have been made, had there been any probability of acceptance." And a recent writer maintains that the connection of Butler's name with the War Department, after that gentleman's resignation from the Van Buren Cabinet had shown that the lesser portfolios could not attract him, was a ruse gotten up by Edwin Croswell, a Democrat editor and State printer for New York. ${ }^{5}$ Polk was able to say, however, that he had made the Van Buren men fair offers."

The Navy Department was assigned to George Bancroft. There

${ }^{2}$ Niles Register, LXVI, 295.

${ }^{8}$ Polk MSS., Walker to Polk, Baltimore, May 20, I844.

"Jenkins, Life of Silas Wright, 202.

${ }^{5}$ Alexander, A Political History of the State of New York, II, 94.

'Polk's Diary, Lenox Library, XIII, 47, XIV, I8. 
is a tradition that Bancroft was recommended for Cabinet honors by connection with a proposed Life of Jackson. In Jackson's correspondence with Van Buren some eight years before this date, there is a reference to the young historian, to whom the ex-President consents to give certain papers, if Amos Kendall will agree." But there is no documentary evidence that this brought Bancroft to the Cabinet. On the other hand, there were ample political reasons for the appointment. Bancroft had asserted some leadership in the Democrat National Convention, by turning the votes of Massachusetts and New Hampshire to Polk, who had previously been thought of only as a suitable running mate for Van Buren. ${ }^{8} \mathrm{He}$ was the choice of New England Democrats for a place in the Cabinet; and Van Buren favored him, if that section of the country was represented at all.'

The connecting of Bancroft with the Navy necessitated the transfer of John Y. Mason, who was retained from the Tyler administration; and Mr. Mason now became Attorney-General. The PostOffice was assigned to Cave Johnson of Tennessee, who enjoyed an intimate friendship with the President, both private and political.

Notwithstanding the unusual complications that entered into the selection of this Cabinet, it was an exceedingly able one. Moreover, a certain leveling up resulted from the fact that the President's personal sympathies were distinctly with the lower end of the Cabinet table. The question of Jackson's relation to the Executive counsels was ended by his death about four months after the inauguration, and happily so. Polk had not adhered to his advice in his most important appointments; and had caused him deep distress by setting up the Daily Union as administration organ, instead of sustaining the Globe.

It was fatal to a hearty cooperation between the President and Secretary of State, that Polk had departed from the advice of his aged Mentor, in making his appointments, after he had espoused the

${ }^{7}$ Van Buren MSS., Jackson to Van Buren, October 29, 1837.

${ }^{8}$ M. A. DeWolfe Howe, Life and Letters of George Bancroft, I, 253; Bancroft to Polk, July 6, I844.

'Polk's Diary, Lenox Library, II, I59; Van Buren to Polk, January 18, 1845. 
doctrine that presidential aspirants are a Cabinet evil. He declined a second term of office for himself; and, putting too much faith in Jackson's scheme of beginning an administration with "written rules," he addressed a letter to each of his prospective Secretaries, stating that any member of the Cabinet who became a candidate for either the Presidency or the Vice-Presidency, would be expected to resign his portfolio, and specifying that he wished to guard against official interference with the succession, by use of the public patronage. ${ }^{10}$ Buchanan replied to this with diffuse protests that really evaded the point. ${ }^{11}$

The sequel was constant suspicion on both sides. Polk noted in his Diary that Buchanan had wavered about the annexation of Oregon, and again that he had vacillated on the Mexican question, and that the motive must be his elevation to the Presidency. The selection of a "Barnburner" newspaper in New York, for the publication of matter over which the State Department had charge, was ascribed to a desire to curry favor with the Van Buren democracy, with which the administration had entirely broken. ${ }^{12}$ The other side of the matter was that Buchanan was nursing resentment over the President's disregard of his interests in dispensing the patronage. The most heated controversy on this point occurred early in the administration; and was concerned with the nomination of Judge Woodward of Pennsylvania for a place on the Supreme Bench, without Buchanan's previous knowledge. The offended Minister wrote the President a caustic letter; but a frank interview precluded his sending it. Buchanan ventured to assert that the occurrence was unprecedented in all the affairs between Presidents and Cabinets; while Polk retaliated that he had not so understood it, that he alone was responsible for his appointments, and that, while he would be happy, if his Cabinet were satisfied, he must act on his own conviction, even if they were not. ${ }^{13}$ Buchanan filed a memorandum, in which he asserted that the dispensing of the Pennsylvania patronage had

\footnotetext{
${ }^{10}$ Polk's Diary, Lenox Library, II, 236.

${ }^{11}$ Curtis, Life of James Buchanan, I, 548.

${ }^{12}$ Polk's Diary, Lenox Library, XVI, 59, 66, 7I ; also XXII, 75.

${ }^{19}$ Polk's Diary, Lenox Library, III, I.
} 
placed him in the false position before the public of being a member of the Cabinet, with the President using all his official patronage to break him down at home." And, as the time for the presidential nominations for 1852 approached, he wrote to one of his colleagues: "The course of Mr. Polk's administration in appointing my bitter enemies to office has done me great injury." ${ }^{15}$ On one or two occasions, Polk also ascribed some independent action on Walker's part to like motives with Buchanan's. ${ }^{16}$

This friction within the Executive would seem to have been serious enough to impair its efficiency, and the fact that it did not have that effect is clear proof of Polk's mastery of the situation, for which he has only received credit within a few years. The dominant note of the administration is that of a President in full control of affairs. Formal consultation under Polk was more frequent than it had been under his predecessors; for he held two Cabinet meetings a week, on Tuesday and Saturday. His personal views on this subject he stated thus: "At each meeting of the Cabinet, I learn from each member of the Cabinet what is being done in his particular Department, and especially if any question of doubt or difficulty has arisen. I have never called for any written opinions from my Cabinet, preferring to take their opinions, after discussion in Cabinet and in the presence of one another. In this way, harmony of opinion is more likely to exist." 17

Upon the Oregon question, Polk took the very unusual course of seeking a previous consultation with the Senate. June Io, I846, he submitted to that body a preliminary convention presented to the Secretary of State by the British Minister. The accompanying message stated that in the early periods of the Government, the opinion and advice of the Senate were often taken in advance upon important questions of our foreign policy. ${ }^{18}$ What inspired President

${ }^{14}$ Buchanan MSS.

${ }^{15}$ Buchanan MSS., Buchanan to Toucey, July I2, I850.

${ }^{18}$ Polk's Diary, Lenox Library, III, 45.

${ }^{17}$ Polk's Diary, Lenox Library, XXI, 6I, September 23, I848.

${ }^{18}$ Richardson, Messages and Papers of the Presidents, IV, 449. Polk was mistaken about this. Some interesting facts about the early practice with regard to previous consultation by written communication are afforded by the 
Polk to resort to this early abandoned expedient, we do not know. But the time had long passed for such a step to have any effect upon the functions of Senate and Cabinet.

The Executive initiative in Congress during Polk's presidency was unusually brisk. The Tariff Act of 1846 was distinctly an administration measure; and in originating other legislation, the Treasury Department was more than ordinarily conspicuous. Furthermore, the affairs with England and Mexico presented an unusual array of matters in which Congress was dependent upon the Heads of Departments.

A series of changes in the Cabinet personnel was set in motion by Bancroft's resignation from the Navy in September, I846. Special interest attaches to this for personal reasons. Bancroft had administered the Navy with unwonted energy, completely giving the lie to the objection that he was a man of books and the closet, with little experience of affairs. But his administration was more efficient than popular. At the Secretary's order, a board of naval officers met at Washington in July I846, to consider the subject of promotions. A proposition was laid before this board that the rule of seniority be given up for a system of merit, which the Secretary should determine. Although this was adopted, it called forth a minority protest and much public criticism. ${ }^{10}$ A little later, the Senate defeated a list of naval appointments. ${ }^{20}$ Bancroft's retirement, however, was inspired, as the President's Diary indicates, by a genuine preference for a diplomatic post. Inasmuch as the English and French Missions were both to be vacated, the subject had come up between President and Secretary some weeks before the unpleasantness in naval circles. The original plan was to send Bancroft to France, because $\mathrm{Bu}$ chanan's name was connected with the other position. But the Secretary of State decided to remain in the Cabinet; and Bancroft was appointed Minister to England. ${ }^{21}$

following references: Writings of Jefferson, I, I9I, Anas, April 9, I792 ; also 220, February 26, I793; also, Life and Letters of George Cabot, 236, Pickering to Cabot, September I3, I799.

${ }^{10}$ Niles Register, LXIX, 323, August 15, 1846.

${ }^{20}$ Senate Executive Journal, August 4, I846.

${ }^{21}$ Polk's Diary, Lenox Library, VIII, Io, I2. 
Mason was now put back into the Navy Department; and Polk looked to New England for an Attorney-General. Nathan Clifford of Maine was appointed, after an offer to Franklin Pierce of New Hampshire. A year and a half later, Mr. Clifford retired, to undertake a commission to Mexico; and Isaac Toucey of Connecticut, became Attorney-General. Mr. Toucey became an intimate friend of Buchanan and was called into his Cabinet.

One of President Polk's last official acts was to sign the Act to establish the Home Department, or the Department of the Interior, March 3, I849. In the first session of Congress, under the Constitution, it had been proposed by Representative Vining of Delaware to establish a separate Home Department ; ${ }^{22}$ but at that time few men thought it necessary to provide an establishment for domestic administration along with the Departments of War, Finance, and Foreign Affairs. In 1816, however, President Madison, in his last Annual Message to Congress, called attention to the fact that the progress and growing population of the country required an additional Executive Department. ${ }^{23}$ Nine years later, President John Quincy Adams, renewed Madison's recommendation; and declared in the light of his own Cabinet experience that the union of Foreign with Interior Affairs, established in the first year of the Government, had become an unquestionable detriment to the public service. ${ }^{24}$ In the discussion of this message by the Cabinet, Clay had said that a new Department was of most urgent necessity; but that he doubted if such a measure would command five votes in the House of Representatives. That body went so far, however, as to appoint a committee to investigate the subject, of which Webster was chairman $;{ }^{25}$ and a bill was projected for a Home Department to have charge of internal correspondence, roads and canals, Indians, and the patent office. Jackson also took up the subject in his First Annual Message; but refused to recommend a Home Department, because such plan had already failed in Congress on account of the belief that it would increase the

\footnotetext{
${ }^{22}$ Annals of Congress, I, 369-37I.

${ }^{25}$ Richardson, Messages and Papers of the Presidents, I, 577.

${ }^{24}$ Richardson, Messages and Papers of the Presidents, II, $3 \mathrm{I} 4$.

${ }^{25}$ Memoirs of John Quincy Adams, VII, 63, 83, I09.
} 
centralizing tendency of the Federal Government. He was none the less urgent for some arrangement that would give the Secretary of State more time for foreign affairs. ${ }^{28}$ The result of this was a project to create the office of Assistant-Secretary of Internal Affairs within the State Department. This jealousy of a Home Department availed to put off its establishment, until the relief of the other Departments became an absolute necessity; moreover, President Polk signed the act reluctantly. ${ }^{27}$ The new Department was given charge over the Patent Office and the Census, which had previously been the business of the Department of State; also over the Land Office and United States Mines, hitherto belonging to the Treasury, over Indian Affairs, which had been in charge of the War Office, and over the Pension Bureau, the supervision of which had been divided between the War and Navy Departments, besides some miscellaneous functions. The expansion of departmental business was further indicated by the creation, under the Home Department Act, of an Assistant Secretary of the Treasury.

${ }^{20}$ Richardson, Messages and Papers of the Presidents, II, 46I.

${ }^{27}$ Polk's Diary, Lenox Library, XXIII, I6o. 
President.

ZACHARY TAYLOR, Louisiana. ((Died July 9, I850.)

ViCE-PRESIDENT.

MILLARD FILLMORE, New York.

March 5, I849, to July 9, I850.

Secretary of State.

James Buchanan, of Pennsylvania; continued from last Administration. John M. Clayton, of Delaware, March 7, i849.

Secretary of the Treasury.

ROBERT J. Walker, of Mississippi; continued from last Administration. McClintock Young (Chief Clerk), ad interim, March 6, i849.

William M. Meredith, of Pennsylvania, March 8, I849.

\section{SeCRETARY OF WAR.}

William L. Marcy, of New York; continued from last Administration. REVERDY JoHnson, of Maryland (Attorney-General), ad interim, March 8, I849.

George W. Crawford, of Georgia, March 8, I849.

\section{AtTORNey-General.}

IsAac ToucEY, of Connecticut; continued from last Administration. Reverdy JoHnson, of Maryland, March 8, I849.

\section{Postmaster-General.}

Cave Johnson, of Tennessee; continued from last Administration.

SetAH R. HoBbIE, of New York (First Assistant Postmaster-General), ad interim, March 5, 1849.

JacoB Collamer, of Vermont, March 8, i849.

Secretary of the Navy.

JoHN Y. MASON, of Virginia; continued from last Administration. William B. Preston, of Virginia, March 8, 1849.

SECRETARY OF THE INTERIOR.

Thomas Ewing, of Ohio, March 8, 1849. 


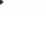




\section{TAYLOR.}

The composition of the Cabinet of President Zachary Taylor is quite inexplicable by any code of rules; and bears abundant testimony to the naiveté of the hero of the Mexican War with regard to government and politics. Two weeks after his nomination, General Taylor communicated to Governor Crittenden of Kentucky, who was serving as his guide and champion, at the price of a former allegiance to Clay, that, if he were elected President, his entire Cabinet should be formed of Whigs. ${ }^{1}$ Apparently Thurlow Weed had imposed upon the Whigs a great risk of forfeiting the spoils to the enemy for a second time, when he so laid the wires, and shuffled the National Convention as to put up a no-party hero for the Presidency. It is alleged, however, that he had not acted without acquainting himself with General Taylor's real sympathies.'

Unlike Harrison, who was not so much of a novice in affairs of government, General Taylor failed to associate himself with the statesmen of the party, though neither Clay nor Webster had shown any hostility to him, after the nomination was determined. For his preliminary instructions, he turned to Crittenden; and his first lesson seems to have been on the impracticability of calling VicePresident Fillmore into the Cabinet. ${ }^{3}$

The pupil made no great progress, however, in the accepted rules for distributing portfolios, though the peculiar combination of States and factions that had elected him, might have rendered them somewhat inapplicable in more experienced hands. The Cabinet arrangements began with an interview at Frankfort, Kentucky, between President-elect and Governor. Crittenden declined the State portfolio for himself, but recommended Senator John M. Clayton of

${ }^{1}$ Coleman, Life of J. J. Crittenden, I, 316; Taylor to Crittenden, July I, I848.

${ }^{2}$ Alexander, A Political History of the State of New York, II, I36.

'Thurlow Weed, Autobiography, 586. 
Delaware, who had been an avowed Cabinet aspirant in the HarrisonTyler administration; and the appointment was promptly arranged by telegraph. Abbott Lawrence, a prominent Massachusetts merchant, who had stood second to Fillmore as candidate for the VicePresidency, was slated for the Navy, and Thomas Ewing of Ohio, Harrison's Secretary of the Treasury, for the Post-Office. The selection of George W. Crawford of Georgia for the War Department was made by Robert H. Toombs and Alexander H. Stephens, after General Taylor arrived at the seat of Government. William M. Meredith, a Pennsylvania lawyer of considerable skill, but without experience of public affairs, was chosen for Secretary of the Treasury, by the advice of Mr. Clayton. Furthermore, Representative William B. Preston, of Virginia, was substituted for Abbott Lawrence in the Navy Department. The Attorney-Generalship was assigned to Senator Reverdy Johnson of Maryland. There is a story that the places assigned to Preston and Johnson were originally reversed; but Preston was not a lawyer, and when the duties of the Attorney-General were explained to General Taylor, the exchange was made. As the Cabinet arrangements were being completed, much feeling was manifested that New England was being slighted. The Treasury was desired by that section of the country, and had been asked for Mr. Lawrence, who deciined the Navy. ExSenator George Evans of Maine was also named for that post; and there is some evidence that Webster supported him. An opportunity was afforded for giving New England a second offer by the creation of the Department of the Interior, on the last day of the expiring administration; and William $H$. Seward of New York, whom the late Whig triumph had sent to the Senate, sought to have the new office put at the disposal, not of Webster, but the newly elected Senator from Connecticut, Truman Smith. The final arrangement, however, was the transfer of Mr. Ewing to the Interior Department, and the appointment of Representative Jacob Collamer of Vermont to the Post-Office." Mr. Seward's first speech in the Senate was to secure the confirmation of the Postmaster-General, which was threatened by an attempt to refer the nomination to a committee, Mr. Collamer

'Seward at Washington, I, 100. 
being singled out from all the others for opposition, because of his abolition sentiments.

It was an exceedingly mediocre Cabinet that was formed in this novel fashion. Though four of its seven members came from slaveholding States, Crawford and Preston afterwards joining the Confederacy, none of them had strength enough to stamp the slave interest upon the administration. The most distinguished member was the Secretary of the Interior, for Mr. Ewing had won some prominence in the two fruitless struggles for a Third Bank of the United States. The Secretary of State is remembered chiefly for the connection of his name with the Clayton-Bulwer Treaty. He threw the Department into such confusion, that his resignation was agitated, and he seems to have written it on two different occasions, and once to have actually tendered it. ${ }^{6}$

The prime force in this brief administration was Seward. Taylor's reliance upon him is an exceedingly good illustration of the confidential relations which sometimes grow out of the President's needs of personal connections with Congress, whereby a Congressional leader becomes a sort of outside Minister. There was a rivalry of brief duration between Senator and Vice-President for the inside track. The Whigs of New York were divided as well as the Democrats. Weed, who was one with Seward, had given an affront to Fillmore at the time of the Whig victory, eight years before, by failing to send him to the Senate in place of Tallmadge, who had previously been a Democrat. And the two factions were shortly to be opposed on the Compromises of 1850, as Radicals and Conservatives, or Seward men and Silver-Grays.' Shortly after the inauguration, Seward wrote to Weed that all idea of calling the Vice-President into the Cabinet had been dissipated; evidently that project of General Taylor's had caused the two some concern.

Seward's control of the patronage was sufficient for Toombs to write to Crittenden, who fell into the background, as General Taylor

'Seward at Washington, I, 106.

'Seward at Washington, I, III ; Clayton MSS., Paper of December, I849; ibid., June 18,1850 .

${ }^{7}$ Alexander, A Political History of the State of New York, II, 30, I55. 
reached Northern influences, that the Senator from New York was being permitted to force the whole Northern Whig party into his anti-slavery position; and that only Crawford, the Georgia member of the Cabinet, was resisting, because Preston of Virginia had been fooled into supposing that Seward's aspirations were for 1856, and that he would yield to the South in 1852 , if given free rein.

Seward's influence extended also to the gravest matters of State. Less than a month after the inauguration, the rumor having gone abroad that the President was false to his promise about the Wilmot Proviso, the Senator from New York published in the National Intelligencer, the organ of the Whigs, a "Vindication of General Taylor on the Free Soil question": for the consideration of which he was privileged to meet with the President and Cabinet." $\mathrm{He}$ also concurred in the project to despatch an executive agent to California for furthering the preparation of a State Constitution.

After the assembling of Congress and the introduction of the Compromises, Seward's Cabinet influence was chiefly with the freeState members; though the division that now began to manifest itself among the Heads of Departments was of little consequence to the relations between the Cabinet and Congress. Clay himself bears witness to the retired position of the Executive; "I have never before seen such an administration. There is very little cooperation or concord between the two ends of the Avenue. There is not, I believe, a prominent Whig in either House that has any confidential intercourse with the Executive. Mr. Seward, it is said, had; but his late abolition speech had, I presume, cut him off from any such intercourse." ${ }^{10}$ But the old chieftain did not know the true inwardness of things at the White House and the Departments. As a matter of fact the notes of the "Higher Law" speech had been approved by Ewing, and had been submitted to Clayton, who was less favorable because the Northern sentiment was too strong. ${ }^{11}$ Moreover Clay's speech of May 2I, 1850, attacking the President

${ }^{8}$ Coleman, Life of J. J. Crittenden, II, 364; April 25, 1850.

- Seward at Washington, I, 108, March 29, 1849.

${ }^{10}$ Clay's Works, ed., 1904, V, 604; Clay to James Harlan, March 16, 1850.

${ }^{11}$ Seward at Washington, I, 125, March II, 1850. 
and administration, caused the Senator from New York to form a plan "to vindicate and defend the administration and the noble old chief " if opportunity should arise. ${ }^{19}$

It is probable that the weak and colorless Cabinet which General Taylor in his inexperience had allowed a medley of advisers to select for him, would have given place to a stronger one, had it not been for his untimely death; for the scandal of the Galphin Claim had driven the President to resolve upon a reconstruction. This was a claim for several thousand dollars put forth by the State of Georgia; and it transpired that Secretary Crawford of the War Department was personally interested in it, notwithstanding that his friend Toombs maintained that the whole affair was an attempt to drive him from office. Other members of the Cabinet shared in the reproach; for Secretary Meredith of the Treasury had ordered the payment of the claim, and Attorney-General Johnson had recommended it. An investigation by the House of Representatives resulted in the censure of the Secretary of War, and morally convicted his two colleagues of stupidity; in which latter verdict Secretary Ewing of the Interior was made to share by the simultaneous discovery of a blunder in the office of Indian affairs, being now a bureau in the Department of the Interior. ${ }^{13}$

The President's plan, as he stated it to Thurlow Weed, was to detain the Senate at the adjournment of the Congressional session, and submit the new appointments. Meredith, Ewing, and Collamer, whom he highly esteemed in spite of the Departmental blunders, were to be transferred to diplomatic posts. The new Cabinet was to have the majority of its members from the free States, which General Taylor regarded as entitled to the larger representation, by virtue of population and industrial interests. Mr. Weed's suggestion that no Southern Whig could be trusted on the tariff, and that a suitable Secretary of the Treasury would be Governor Hamilton Fish of New York, was apparently received with tacit consent; wherein lies an intimation that Seward would have remained in the Senate. ${ }^{14}$

\footnotetext{
${ }^{12}$ Seward at Washington, I, 134, May 22, I850.

${ }^{13}$ Seward at Washington, I, I30, I33, 143.

${ }^{14}$ Autobiography of Thurlow Weed, 590, 59I.
} 
Notwithstanding the insipidity of the Taylor Cabinet, the Executive relations during this brief administration are not without interest. They show on the part of a President, entirely untrained in politics and affairs of State, a power to identify himself with the rising forces in the Government, which his more experienced successors did not possess. 


\section{President. \\ MILLARD FILLMORE, New York. \\ President Pro Tempore of the Senate. \\ WILLIAM R. KING, Alabama.}

July 9 , I850, to March 4 , I853.

\section{Secretary of State.}

John M. Clayton, of Delaware; continued from Taylor's Administration. DANIEL Webster, of Massachusetts, July 22, 1850.

Charles M. ConRad, of Louisiana (Secretary of War), ad interim, September 2,1852 .

EDWARD EvERETr, of Massachusetts, November 6, 1852.

William Hunter (Chief Clerk), ad interim, March 4, I853.

Secretary of the Treasury.

William M. Meredith, of Pennsylvania; continued from Taylor's Administration.

Thomas Corwin, of Ohio, July 23, 1850.

SECRETARY OF WAR.

GEORGE W. CRAWFord, of Georgia; continued from Taylor's Administration. SAmuel J. Anderson (Chief Clerk), ad interim, July 23, I850.

WiNFIELd Scott (Major-General, U. S. A.), ad interim, July 24, 1850.

Charles M. Conrad, of Louisiana, August I5, I850.

\section{Attorney-General.}

REVERDY JoHnson, of Maryland; continued from Taylor's Administration. John J. Crittenden, of Kentucky, July 22, 1850.

\section{Postmaster-General.}

JacoB Collamer, of Vermont; continued from Taylor's Administration.

Nathan K. Hall, of New York, July 23, I850.

SAmuel D. HubBarn, of Connecticut, August 31, I852.

Secretary of The Navy.

William B. Preston, of Virginia; continued from Taylor's Administration.

William A. Graham, of North Carolina, July 22, I850.

LEWIS WARRINGTON (Captain, U. S. N.), ad interim, July 23, 1850. John P. KenNedy, of Maryland, July 22, 1852.

\section{SECRETARY OF THE INTERIOR}

Thomas Ewing, of Ohio; continued from Taylor's Administration.

DANIEL C. Goddard (Chief Clerk), ad interim, July 23, I850.

Thomas M. T. McKennan, of Pennsylvania, August 27, 1850.

Daniel C. Goddard (Chief Clerk), ad interim, August 27, 1850.

Alexander H. H. StUART, of Virginia, September I2, I850. 


\section{FILLMORE.}

The accession of Vice-President Fillmore to the Presidency on July Io, I850, gave the government into the hands of the Compromise Whigs; for the Seward faction now had to yield to the SilverGrays. The Cabinet situation was very different from what it had been at Tyler's accession nine years before. The fact that Taylor's advisers were not in touch with Congress, together with the reproach of the Galphin Claim threw the weight of opinion in favor of a complete change; moreover, the principle now began to be applied to an accidental President that, unless he appointed his own Cabinet, the administration would not be his own. ${ }^{2}$ Seward waited upon Mr. Fillmore and advised the retention of all of the existing Cabinet, except the Secretary of War, urging as the least consideration that the Secretary of State be retained. But the members of the Cabinet, though all of them except Crawford would have preferred to remain at their posts, professed such eagerness to withdraw, that they had to be urged to allow the President time to look for their successors, and their resignations were accepted to take effect July 22.

President Fillmore turned at once to Clay and Webster, and formed his administration in much the same fashion as Harrison had done, though change of issues and the advanced years of the two statesmen made the situation somewhat different. Clay, as before, desired Cabinet honors for his rival but not for himself; which significant fact called forth the following from Fletcher Webster: "Mr. Clay is very anxious to have father go into the Cabinet. This alarms me. He would not do it, unless he thought it would dispose of Mr. Webster out of his way. I am afraid of the kisses of an enemy." 2 The new President further consulted Clay about his relations with Crittenden, and was informed that there was

${ }^{1}$ Seward at Washington, I, I45-149.

${ }^{2}$ Van Tyne, Letters of Daniel Webster, 420 ; Fletcher Webster to Peter Harvey, undated. 
no obstacle to appointment of that gentleman to the Cabinet, although the former intimacy was at an end. Accordingly, Mr. Crittenden, whose governorship had now expired, assumed the AttorneyGeneral's office for the second time. Further than this, the restoration of the Harrison Cabinet did not go; for Mr. Ewing, the natural representative of the North-West had identified himself with the Seward wing of the party. The Treasury portfolio was assigned, however, to Senator Thomas Corwin of Ohio, whose remarks on the Mexican War were too well remembered to make the appointment altogether popular; in fact Seward prepared himself to champion Corwin's confirmation, if obstruction should be attempted. In providing for the other Departments, President Fillmore experienced a good deal of difficulty. All were inconspicuously filled, and there was much shifting.

The State Department also changed hands before the close of the administration. Webster's second incumbency had been much interrupted by ill health, which became more serious, after he was disappointed of the presidential nomination of 1852 ; at the close of September of that year, he resigned, being within a few weeks of his death. Edward Everett, who had the same constituency and political affiliations as Webster, succeeded him; and maintained the dignity of the Department according to the standard of his predecessor, although his brief incumbency afforded no opportunity for great distinction.

The Fillmore administration, with its achievements in the field of foreign affairs, and its harmonious relations with Congress, showed average strength. In the affairs of State, the President was overshadowed by the Secretary; but in his political following he had the advantage. The intrusion of an accidental President into an administration, has never failed to complicate the question of the presidential succession; and on this occasion the Cabinet relations were involved. Just as Clay was removed by physical collapse in the session of $185^{1-'} 52$, Webster found a new rival in Fillmore, and Fillmore probably enjoyed Clay's support. Though the situation was a delicate one, no Cabinet rupture resulted, neither did personal friction outwardly weaken the administration. 
On the whole, the Whigs raised the status of the Cabinet above the level to which it had sunken during the Jackson regime, notwithstanding the shocks suffered by the extraordinary number of changes in the Executive personnel. For, while the Whig party degraded the Presidency, by setting aside its statesmen for candidates with purely popular qualifications, it restored the old standard of Cabinet ability by reversing Jackson's rule that excluded presidential aspirants from the Departments. There was also a gain in the influence of the Cabinet with Congress. A few weeks before Tyler's break with the Whigs, Silas Wright asserted that he had never known the Executive influence to be so much felt in the Upper House, and Mr. Wright had entered the Senate in Jackson's presidency. Despite the vicissitudes that followed, the Cabinet was again influential when the Whig period closed. The Executive initiative, however, was not so much felt as it would have been, had Clay consented to become a member of the administration.

On the last day of the Fillmore administration, March 3, 1853, an act was passed raising the salaries of the Cabinet officers and placing the Attorney-General and Postmaster-General upon the same level with the Secretaries. This act also created the office of Assistant Secretary in the Department of State. 


\section{President.}

FRANKLIN PIERCE, New Hampshire.

VICE-PRESIDENT.

WILLIAM R. KING, Alabama. (Died April 18, 1853.)

President Pro Tempore of the Senate.

David R. Atchison, Missouri.

LEWIS CASS, Michigan.

Jesse D. BRIght, Indiana.

Charles E. Stuart, Michigan.

JAMES M. MaSON, Virginia.

March 4, I853, to March 4, 1857.

\section{Secretary of State.}

Willia M Hunter (Chief Clerk), ad interim, March 4, I853.

William L. Marcy, of New York, March 7, 1853.

Secretary of the Treasury.

Thomas Corwin, of Ohio; continued from last Administration.

JAmes Guthrie, of Kentucky, March 7, 1853.

Secretary of War.

Charles M. Conrad, of Louisiana; continued from last Administration. JefFerson DAvis, of Mississippi, March 7, 1853.

SAMuel Cooper (Adjutant-General, U. S. A.), ad interim, March 3, 1857.

Attorkey-General.

John J. CRITTENden, of Kentucky; continued from last Administration.

Caleb Cushing, of Massachusetts, March 7, I853.

Postmaster-General.

Samuec D. Hubbard, of Connecticut; continued from last Administration. James Campbell, of Pennsylvania, March 7, 1853.

SeCRETARY of the Navy.

JoHn P. KenNedy, of Maryland; continued from last Administration.

James C. Dobbin, of North Carolina, March 7, 1853.

SECRETARY OF THE INTERIOR.

Alexander H. H. Stuart, of Virginia; continued from last Administration. ROBERT MCClelland, of Michigan, March 7, 1853. 


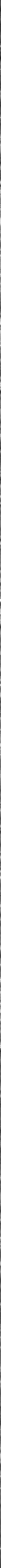




\section{PIERCE.}

The conditions that attended the making of a Democrat Cabinet in 1852 strongly resembled those of 1844 ; but there is not so much information available about the demands that confronted Pierce as there is in the case of Polk. The strong competitors for the presidential nomination, before a sufficiently colorless candidate was found in Franklin Pierce of New Hampshire, had been Cass, Buchanan, Marcy, and Stephen A. Douglas. The factional divisions within the larger States had changed form in eight years. In New York, there were now the "Softs" and "Hards" who united for the election of the President, but resumed their rivalries so soon as the administration was inaugurated. In Pennsylvania Buchanan was in the ascendant; and the strength of his following is indicated by the choice of one of his particular friends, William R. King of Alabama, as the candidate for the Vice-Presidency.

With his rival from the Keystone State, Pierce desired amicable but not intimate relations; and Buchanan's conflicting emotions with regard to the comparative abasement to which he was subjected give a good deal of flavor to the story of how the administration was formed. Early in December, the President-elect entered into correspondence with the ex-Secretary of State; and, with kind but explicit announcement that Buchanan himself would not be invited into the Cabinet, he asked for other suggestions. The correspondence resulted in the appointment of James Campbell of Pennsylvania to the Postmaster-Generalship. ${ }^{1} \quad$ Additional political significance attached to the fact that Judge Campbell was a Roman Catholic in religion, since the President-elect had been charged with favoring the religious test act of New Hampshire. ${ }^{2}$

${ }^{1}$ Buchanan MSS., Letters between Pierce and Buchanan, 1852; also Buchanan to Campbell, March 10, 1853 .

${ }^{2}$ Daily Union, August 7, 1853. 
The Treasury portfolio went to the South, as it had done under Polk, the new Secretary being James Guthrie of Kentucky, a man of advanced years, who was prominent in the affairs of his State, but was unknown in National politics. The War Department was pressed upon Jefferson Davis of Mississippi, who had won distinction in the Mexican War, and when confronted with a choice between a Cabinet office and a seat in the Senate, decided reluctantly in favor of the former. The Navy portfolio was assigned to James C. Dobbin, a young North' Carolina lawyer, who had been a controlling force in the Democrat National Convention, and had nominated Pierce for the Presidency. The Interior Department was given to Robert McClelland of Michigan, a former member of the House of Representatives, and Governor of his State, this arrangement being a concession to the Cass interest. The chosen representative of New England was Caleb Cushing of Massachusetts; and there is a tradition that Pierce would have put him over the State Department, had it not been that, in spite of his fellowship with Tyler, the South was mindful that Cushing had once companied with abolitionists. ${ }^{3}$

The State portfolio had been reserved for New York; but the difficulty of choosing between the factions there deferred the final arrangement, until two or three days beyond the usual time for submitting the Cabinet slate to the Senate. John A. Dix, who had been very prominent within the State, and had also had a short service in the United States Senate, was singled out as a suitable incumbent, and was bidden to Pierce's home at Concord, to receive there a definite offer of the State portfolio. Mr. Dix, however, had been a "Barnburner;" and in 1848 , he had run for the office of Governor on the Free-Soil ticket. And, when it was pointed out to the President-elect, that such a selection might cost him the support of the Southern Democracy, he sought a release from the engagement." Mr. Dix's opportunity for Cabinet distinction was thereby postponed to a later administration. And the State portfolio was shifted to Marcy, whose "Hunker" conservatism on the issues that had begun to divide the party eight years before rendered his past

\footnotetext{
${ }^{3}$ Ben Perley Poore, Reminiscences, I, 427.

- Memoirs of John A. Dix, I, 271, 272.
} 
less objectionable. It was thus an afterthought that Pierce put at the head of his Cabinet one of his prominent competitors for the presidential nomination.

The qualifications of Polk's Secretary of War for such elevation do not greatly suffer for being reflected through the medium of Buchanan's disaffection. Writing to one of their common colleagues, the former Secretary of State said: "I have no cause of complaint against Marcy. .... He would have succeeded in any other Department of the government; but I know of no other man of experience and character who is more ignorant than he is of all which relates to our foreign affairs. He has never made them any portion of his study. But he has a cool, clear head, and a strong intellect, and I place great reliance on his capacity. He may and I trust will succeed. . . . . It is but justice to the President to remark that he had good reasons to believe that I did not desire the State Department at the time he appointed Marcy. Still less do I desire the mission to England." " Inasmuch as Buchanan accepted the mission to England, which he quitted in time to prepare for the presidential canvass of 1856 , it may be inferred that he would not have declined a second incumbency of the State Department.

The Pierce Cabinet was an able one. With Marcy, Davis, and Cushing among its members, there were strong and varied personalities about the council table. This administration is proverbial, moreover, for its stability, being the only one that has experienced no change of personnel; although both Washington and Jefferson, barring the delays that attended the forming of an administration in the early years of the Government, passed through a single term of office, without parting with any of their Ministers.

An extraordinary mastery over men on the part of President Pierce is held up by Southern writers, as the explanation of the stability of his Cabinet, as well as of the great harmony which they claim for it." The same authorities, nevertheless, portray Pierce as a President who so disliked to cause pain to his opponents that he had the air of seeking a compromise; and admit that he surmounted differences by

'Buchanan MSS., Buchanan to Cave Johnson, May 3, I853.

- Alfriend, Life of Jefferson Davis, 89. 
agreeing with his adversary. It is asserted that on only one occasion was there any serious disagreement between him and Secretary Davis, and that this was settled by the President's saying that he would take the responsibility; this one difference, moreover, was on a minor point. Such harmony in Cabinet affairs is phenomenal; and its existence at this date between the future President of the Confederacy and a President of the United States, bred in the traditions of New England, points to great adaptability on one side or the other.

The farewell letters exchanged between Pierce and his Cabinet

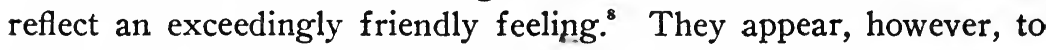
have been somewhat of a formality; for the Fillmore Cabinet upon retiring had joined in a cordial letter of farewell to the President, and Tyler had gone so far as to include a tribute to his Cabinet in his last Annual Message to Congress.

The inside relations of this administration are better revealed by the impartial and searching investigations of Mr. James Ford Rhodes than by the eulogies upon Jefferson Davis. By importuning Davis to enter the Cabinet, and breaking off the arrangement with Dix, Pierce had foreshadowed a policy of concession to the slave interest, and had identified himself with what proved to be the controlling spirit in Congress. The rearrangement of the Cabinet slate had done much to forestall dissension in the Executive, but had not entirely precluded it ; for Marcy, despite his previously acceptable record, did not show himself adaptable to the slave interest in its new aspects. An antagonism immediately developed between Marcy and Cushing. Less than a month after the inauguration, this was commented upon by Seward, who was fast becoming opposition leader in the Senate." There were also rumors inside of the party loud enough to reach Buchanan at London. ${ }^{10}$

Upon the Kansas-Nebraska Bill, the Cabinet became distinctly divided. The Daily Union, being the Democrat organ, gave out that this was an administration measure. ${ }^{11}$ And Seward believed that the

${ }^{7}$ Memoir of Jefferson Davis, I, 544.

${ }^{8}$ American Historical Review, X, 354.

- Sezuard at Washington, I, 203.

${ }^{10}$ Buchanan MSS., Buchanan to Forney, December 13, 1853.

${ }^{11}$ March 22, 1854. 
section for the repeal of the Missouri Compromise was agreed upon at a meeting of Douglas with the whole Cabinet." But Davis' more authoritative account is to the effect that Douglas, with other members of the Committee, called first upon himself; and that he repaired with them to the Executive Mansion, to enlist the aid of the President. He makes no mention of other Secretaries; but implicitly denies that the bill was prepared by the President or any member of the Cabinet. ${ }^{13}$ Cushing joined Davis as a champion of the measure, but Marcy was uncertain from the first. ${ }^{14}$ McClelland, who represented the North-West, was also inactive. The Secretary of State hesitated more and more, as he foresaw the effect of the measure upon the integrity of the Democrat party; and he finally contemplated resignation from the Cabinet. Moreover, it was the solicitude of Marcy's friends, lest his withdrawal should forfeit all that their wing of the party possessed, more than tactful management on the part of Pierce, that held him to his post..$^{15}$

The selection of Davis as the intermediary between the authors of the Kansas-Nebraska Bill and the President is a good measure of the influence exerted by the Secretary of War in this administration. He largely dictated the behavior of the Executive towards the disorders in Kansas, and brought about the concessions to the slave interest.

President Pierce's habit of seeing things the way his advisers saw them has given rise to a tradition that his customary practice in reaching a decision was to take a poll of the Cabinet, and adopt the opinion of the majority. Stronger Presidents than he have resorted to Cabinet polls on occasion ; and have adopted the majority opinion, where they could not see their own way, or even yielded to it on minor points. The charge that Cabinet polls were habitual with Pierce scarcely admits of proof from such material as is at present available; and should rather be regarded as a general formula for his amiable fashion of allowing his advisers to make up his mind for him.

\footnotetext{
${ }^{12}$ Seward at Washington, I, 217, 218.

${ }^{13}$ Jefferson Davis, Rise and Fall of the Confederate Government, I, 27.

${ }^{14}$ Memoirs of John A. Dix, I, 285.

${ }^{13}$ Rhodes, History of the United States, I, 48I.
} 
President.

JAMES BUCHANAN, Pennsylvania.

VICE-PRESIDENT.

JOHN C. BRECKINRIDGE, Kentucky.

March 4, 1857, to March 4, 1861.

Secretary of State.

William L. Marcy, of New York; continued from last Administration.

LEWIS Cass, of Michigan, March 6. 1857.

William Hunter (Chief Clerk), ad interim, December I3, 1860.

Jeremiah S. Black, of Pennsylvania, December 17, I860.

Secretaryi of the Treasury.

James Guthrie, of Kentucky; continued from last Administration.

Howell CoBB, of Georgia, March 6, 1857.

IsAAC ToucEY, of Connecticut (Secretary of the Navy), ad interim, December I0, I860.

Philip F. Thomas, of Maryland, December 12, 1860.

JoHn A. Dix, of New York, January II, I86I.

\section{SECRETARY OF WAR.}

Samuel Cooper (Adjutant-General, U. S. A.), ad interim, March 4, 1857. JoHN B. FLOYd, of Virginia, March 6, 1857.

JOSEPH HOLT, of Kentucky (Postmaster-General), ad interim, January I, I86I.

JoSEPH HoLT, of Kentucky, January 18, 186I.

\section{Attorney-General.}

Caleb Cushing, of Massachusetts; continued from last Administration.

Jeremiah S. Black, of Pennsylvania, March 6, I857.

Edwin M. Stanton, of Pennsylvania, December 20, I860.

\section{Postmaster-General.}

James Campbell, of Pennsylvania; continued from last Administration. AARON V. Brown, of Tennessee, March 6, 1857.

Horatio King, of Maine (First Assistant Postmaster-General), ad interim, March 9, 1859 .

Joseph HoLT, of Kentucky, March I4, 1859.

Horatio KING, of Maine, (First Assistant Postmaster-General), ad interim, January I, I86r.

Horatio KING, of Maine, February 12, I86r.

Secretary of the Navy.

James C. DobBin, of North Carolina; continued from last Administration. Is $\triangle A C$ Toucey, of Connecticut, March 6, I857.

SECRETARY OF THE INTERIOR.

ROBERT MCClellaAND, of Michigan; continued from last Administration. JacoB Thompson, of Mississippi, March 6, 1857.

Moses KeLLY (Chief Clerk), ad interim, January Io, I86r. 


\section{BUCHANAN}

The election of 1856 brought to James Buchanan the opportunity to make a Cabinet for himself; for the former Secretary of State and Minister to England now received the presidential nomination over Pierce, who had won in the South a strong support for a second term of office, but was much less acceptable to the Northern Democracy than his rival from Pennsylvania. The third candidate on the list was Douglas, and at the foot stood Cass commanding only seven votes at the most. From his seat in the Senate, which he had held since the inauguration of President Polk, General Cass was about to be deposed; for his constituency was in possession of the newly formed Republican party. This at least left him free to receive more distinguished attention than he ever had done before in the formation of the Cabinet. On February 23, the President-elect wrote to the English Minister of Foreign Affairs: "General Cass is to be my Secretary of State, and no Englishman need feel the least uneasiness on this account. His anglophobia, as you used facetiously to term it, if it ever existed, no longer exists. His age, his patriotism, his long and able public services, his unsullied private character and the almost universal feeling in his favor rendered his appointment peculiarly appropriate." ${ }^{2}$ Since General Cass was already in his seventyfifth year, Buchanan probably viewed this appointment as a semihonorary one. He himself was prepared to take a more direct part than recent Presidents had done in foreign affairs; furthermore, there was now an Assistant Secretary of State. However, the letter in which the State portfolio was formally tendered to Cass paid a graceful compliment to the phenomenal preservation of his physical and mental vigor. The Treasury portfolio, Buchanan like Pierce, assigned to the South, appointing Howell Cobb of Georgia, a man of distinguished experience in the House of Representatives, and later a

${ }^{1}$ Buchanan MSS., Buchanan to Lord Clarendon, February 23, 1853. 
member of the Congress of the Confederacy, and an officer of rank in its army. Both for his talents and his personal qualities, Secretary Cobb was highly esteemed by Buchanan; and it was a source of gratification that no personal rancor attended their separation. The War Office was conferred upon ex-Governor John B. Floyd of Virginia; an appointment for which Buchanan was afterwards pleased to excuse himself by saying that the electoral college of Virginia had recommended Mr. Floyd for a seat in the Cabinet, in which matter that gentleman had shown a most commendable modesty, and that the position of his family was also a credential. The Navy Department was assigned to Isaac Toucey of Connecticut, who, like Cass, was about to yield his seat in the Senate to a Republican; Mr. Toucey had been one of President Buchanan's colleagues in the Polk Cabinet. Jeremiah S. Black of Pennsylvania, a brilliant lawyer, and Chief Justice of the Supreme Court of that State, became AttorneyGeneral. The extraordinary relation which he afterwards assumed towards his nominal chief lends interest to the fact that $\mathrm{Mr}$. Buchanan subjected himself to a good deal of opposition among the politicians of Pennsylvania in making this appointment. ${ }^{2}$ The Interior Department was assigned to Jacob Thompson of Mississippi, formerly a somewhat prominent member of the House of Representatives. As to whether this arrangement was dictated by Jefferson Davis, we have found no evidence; though the relations of the parties concerned would justify such an inference. Secretary Thompson afterwards became Governor of Mississippi under the Confederacy, and an officer in the Confederate army. A Postmaster-General was found in the person of ex-Governor Aaron V. Brown of Tennessee; who, however, died in office and was succeeded by Joseph Holt of Kentucky. In the crisis of the administration, Mr. Holt like Judge Black became a great executive force.

The significant period in Buchanan's Cabinet affairs does not begin until the election of his successor, Abraham Lincoln, to the Presidency, November 6, 1860 . The enormous demand, made upon the President by the crisis that ensued, was met by the assumption of a virtual regency on the part of such of his Ministers as were loyal to

'Buchanan MSS., Buchanan to Black, March 6, 1857. 
the Union, a situation without parallel in the history of the Executive. A necessary incident of this was a Cabinet reconstruction, indeed, we are prompted to say, two reconstructions; for, although the several changes occurred at intervals of but a few days, and only one Department twice changed hands, they reflect two distinctly different stages in the handling of the secession problem.

The preparations for secession from the Union, in which South Carolina was taking the lead, called forth in the President's Annual Message of December 3, I860, the declaration that secession was not a Constitutional right of the States, but along with it the contrary proposition that Congress had no authority to coerce into submission a State that had actually seceded, or was attempting such a course. The non-coercion doctrine had been asserted by the Attorney-General in a recent opinion; moreover, it had the apparent sanction of the other Northern members. The denial of a right of secession, however, caused the Southern Secretaries to take issue ; and on December 8 , Cobb of the Treasury quitted the administration. However, Thompson of the Interior, who was equally devoted to the Southern cause, stuck to his post, out of deference to the President's wish that his Secretaries should go out of office at the same time with himself.

What the President hoped to accomplish by keeping the Cabinet outwardly intact, after such schism existed in its sentiments and purposes, would be hard to tell. But it would seem that he was more concerned about his personal relations than he was about the fate of the Government. As he himself expressed it, six years afterwards in his vindication of his administration: "The President had earnestly desired that his Cabinet might remain together until the close of the administration. He felt sensibly the necessary withdrawal of some of its members, after all had been so long united in bonds of mutual confidence and friendship."

Meanwhile, the Secretary of the Interior was retained, although he publically undertook the office of Commissioner of the State of Mississippi to the State of North Carolina, to influence the latter to take secession measures. Secretary Floyd likewise remained at his post, despite suspicion regarding the distribution of the government

'The Administration of James Buchanan, III. 
arms. Moreover, the vacancy in the Treasury Department was filled by the appointment of another secessionist, Philip F. Thomas of Maryland.

The next break in the Cabinet came from the North. General Cass, notwithstanding his acquiescence in the doctrine of noncoercion, two weeks before, had felt his Union sentiments outraged at the President's supineness about protecting the national property in Charleston harbor; and on December 12, with free expression of his views as to his chief's behavior in the matter, he tendered a formal resignation of the State Department," the acceptance of which was not assured until three days later. On the 13 th, the retiring Secretary attended a Cabinet meeting and made a final plea for the forts at Charleston; and, to quote Secretary Floyd's description: "The President said to him in reply, with a beautiful countenance and with a heroic decision : ....' I have considered this question. I am sorry to differ from the Secretary of State; I have made up my mind. The interests of the country do not demand a reenforcement of the forces in Charleston. I cannot do it . . . . and I take the responsibility upon myself." " Postmaster-General Holt tried to urge his Northern colleagues to reconsider his action, averring that the loyal members of the Cabinet ought, more than ever, to stick to their posts; but the aged Secretary insisted that for him to remain would be treasonable, though the same argument did not apply to a member from a border State. On the 15 th, the President accepted the resignation by formal letter, reiterating his determination not to strengthen the forces at Charleston. The blunt frankness of this affair left a wound that always rankled in Mr. Buchanan's breast; and while dealing gently with the memory of his Southern colleagues in his later utterances, he was not averse to disparaging the record of General Cass. In preparing his vindication of his administration, he purposed to say that the Secretary of State had sought to recall his resignation, but that the President would not permit him to do so; however, Judge Black, whose account of an interview with Cass was to be used for evidence,

${ }^{4}$ Curtis, Life of Buchanan, II, 397.

${ }^{5}$ Nicolay and Hay, Abraham Lincoln, II, 396-398.

${ }^{8}$ Buchanan MSS., Buchanan to Toucey, May I3, I864. 
declined to make any statement for publication. The break in the State Department was tided over by the Assistant Secretary William F. Trescott, who was a South Carolinian, and was using his office to the advantage of that S.tate. But December 17, Attorney-General Black was promoted to the State Department; and was promptly succeeded in his former office by Edwin M. Stanton, also of Pennsylvania, which arrangement seems to have been a condition of Black's

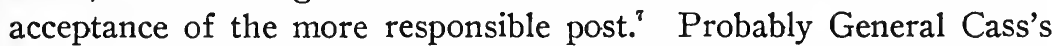
refusal to associate with such an administration longer had not been without effect upon the loyal sentiment in the Cabinet. The same spectacle that had wrought upon him had worked a simultaneous development in the views of Black. November 20, as Attorney-General, he had given an opinion against offensive coercion by the $\mathrm{Na}$ tional Government; but early in December, he asserted in a memorandum to the President a right of coercion for defensive purposes. ${ }^{8}$ Furthermore, Mr. Stanton, whom he selected for his successor in the Attorney-Generalship was known to be in accord with himself in his Union sentiments. The yielding of Buchanan to this influence, may be viewed as the preparation for the stand of the Executive against secession.

The next change in the Cabinet had other significance than the sectional crisis; but was permitted to be glossed over, as of one kind with the other resignations. It transpired that Secretary Floyd was implicated in a defalcation in the Bureau of Indian Affairs, where his notes were appearing in lieu of bonds amounting to nearly a million of dollars. On December 23, President Buchanan preserving his wonted graciousness by making one of Mr. Floyd's friends his agent, communicated a request for the Secretary's resignation, and received an answer that the request would be complied with; no resignation followed, however, until the shaping of the Southern question afforded a good pretext for quitting the War Department. The removal of the United States garrison at Charleston from Fort Moultrie to Fort Sumter, together with the arrival of the South Carolina Commissioners at Washington, brought the opportunity;

${ }^{7}$ Gorham, Edwin M. Stanton, I, I3I.

${ }^{8}$ Gorham, Edwin M. Stanton, I, I22. 
and Mr. Buchanan himself gives a partial account of the insolent manner in which it was embraced. The Cabinet was now in almost continuous session; and at a meeting of December 27, the Secretary of War, who had not resorted to secession utterances before, presented a paper in which he charged that Major Anderson's removal from Moultrie to Sumter was a gross violation of solemn pledges, and demanded that the garrison be withdrawn altogether." The posibility of the President's acceding to this demand caused the new Attorney-General and presumably some of his colleagues to prepare for resignation ${ }^{10}$ but the issue was that the Secretary of War resigned. Incidentally to the discussion of the proposition for the removal of the garrison, Mr. Stanton referred to the disappearance of the Indian trust funds, and Mr. Floyd did not appear again among his colleagues. On the 29th, being Saturday, he tendered his resignation on the ground that he could not be the agent of the Government in its policy of bloodshed." The following Monday, Postmaster-General Holt was put in charge of the War Department, at first temporarily.

The establishment of the Cabinet Regency is signalized by the preparation of the reply of the Executive to the Commissioners from South Carolina as much as by any one event. On the night of December 29, President Buchanan submitted a letter which he had prepared, announcing, in reply to the demands of the Commissioners, a continuation of his policy of inaction. Only Secretary Toucey, the member from New England approved. Thompson and Thomas wished that the answer should be one of concession to the South, while Black, Stanton, and Holt demanded that it should declare an unmistakable purpose to preserve the Union. The President adhered to his plan of neutrality, however, until news was brought to him on the following morning that Secretary Black had announced a determination to withdraw from his service. A hurried interview with that officer led to the surrender of the important paper into his hands; and Black assisted by Stanton, with Holt concurring, drafted a substi-

- Administration of James Buchanan, I85-188.

${ }^{10}$ Gorham, Edwin M. Stanton, I, 156.

"Gorham, Edwin M. Stanton, I, I54. 
tute with the President's promise that he would sign what they submitted. ${ }^{12}$ It is asserted by one authority that the President did not actually use the reply prepared by his Ministers but a second one of his own preparation. ${ }^{13}$ Howbeit, the insolent rejoinder of the South Carolina agents, with other occurences, constrained him to yield to the Unionist influence.

The second reconstruction of the Cabinet now occurred. January 2, a meeting was held to consider the reenforcement of the garrison at Charleston. Six days later occurred the expedition of the Star of the West; and Thompson siezed it as a pretext for resignation. So recently as December 3I, the President had followed up his reply to the South Carolina Commissioners with the suspension of orders for the sailing of the Brooklyn; and the Secretary of the Interior had won from him a promise not to resume the reenforcement plan without previous discussion in Cabinet. Notwithstanding the session of January 2, the Secretary boldly accused his chief of bad faith; and for once Mr. Buchanan returned a spirited answer. ${ }^{14}$ During the remainder of the administration the direction of the Interior Department devolved upon its chief clerk.

One day later, January 9, Thomas was forced out of the Treasury. The bankers and capitalists of New York City, impelled by the impending financial situation, had communicated to the President a resolution to enter into no fiscal transactions with the National Government, until he placed in the Cabinet men upon whom the friends of the Union could depend; and they further made the specific condition that John A. Dix should be appointed Secretary of the Treasury. At an interview of January 8, Mr. Dix was offered the War Department, which had not had a regular incumbent since Secretary Floyd's withdrawal. The President was informed that only the Treasury would be considered; and having secured the resignation of Thomas, for which the Star of the West expedition afforded a timely pretext, he appointed Mr. Dix Secretary of the Treasury, on January II. ${ }^{15}$ On the 17 th, Mr. Holt was regularly

\footnotetext{
${ }^{12}$ Nicolay and Hay, Abraham Lincoln, III, 73-86.

${ }^{13}$ Gorham, Edwin M. Stanton, I, I47.

${ }^{14}$ Buchanan MSS., Buchanan to Thompson, January 9, I86r.

${ }^{15}$ Memoirs of John A. Dix, I, 362.
} 
appointed Secretary of War, the vacancy in the Post Office being filled by the promotion of Horatio King, previously First Assistant Postmaster-General.

The Cabinet Regency was now fully established, Black, Stanton, Holt, and Dix being its members. The triumph of Union sentiment in the Executive had been signalized January 8, by the transmission of a message to Congress wherein the right of defensive coercion was asserted, after the manner of Judge Black's memorandum of a month before. This was followed by numerous acts for the enforcement of the laws of the National Government within the disaffected States. But every important measure was traceable to the four Ministers. ${ }^{16}$ And such resistance as their nominal chief occasionally opposed to their movements was promptly overcome. ${ }^{17}$

Under the second group of Democrat Presidents, the Cabinet had unmistakably gathered head as a part of the Executive. It remained to be seen whether it could preserve such a dominant position in the hands of Abraham Lincoln.

${ }^{18}$ Rhodes, History of the United States, III, 287.

${ }^{17}$ Nicolay and Hay, Abraham Lincoln, III, 130. 
President.

ABRAHAM LINCOLN, Illinois.

VICE-PRESIDENT.

HANNIBAL HAMLIN, Maine.

March 4, I86r, to March 4, I865.

Secretary of State.

Jeremiah S. Black, of Pennsylvania; continued from last Administration. William H. Seward, of New York, March 5, I86r.

Secretary of the Treasury.

Johs A. Dix, of New York; continued from last Administration.

Salmon P. Chase, of Ohio, March 5, I86r.

George Harrington, of the District of Columbia (Assistant Secretary), ad interim, July $\mathrm{I}, \mathrm{I} 864$.

William P. Fessenden, of Maine, July I, I864.

George Harrington, of the District of Columbia (Assistant Secretary), ad interim, March 4, I865.

Secretary of War.

Joseph HoLt, of Kentucky; continued from last Administration.

Simon Cameron, of Pennsylvania, March 5, I86I.

Edwin M. Stanton, of Pennsylvania, January I5, 1862.

Attorney-General.

Edwin M. Stanton, of Pennsylvania; continued from last Administration.

EDward Bates, of Missouri, March 5, I86I.

JAMES SPEED, of Kentucky, December 2, I864.

Postmaster-General.

Horatio KING, of Maine; continued from last Administration.

Montgomery BlaIR, of the District of Columbia, March 5, I86I.

William Dennison, of Ohio, September 24, 1864.

SeCretary of The NAvy.

IsAAC Toucey, of Connecticut; continued from last Administration.

Gideon Welles, of Connecticut, March 5, I86I.

SECRETARY OF THE INTERIOR.

Moses Kelly (Chief Clerk), ad interim, March 4, I86I.

Caleb B. Smith, of Indiana, March 5, i86I.

John P. Usher, of Indiana (Assistant Secretary), ad interim, January I, I863.

JoHN P. UsheR, of Indiana, January 8, 1863. 
President.

ABRAHAM LINCOLN, Illinois. (Died April 15, 1865.)

Vice-President.

ANDREW JOHNSON, Tennessee.

March 4, I865, to April I5, I865.

Secretary of State.

William H. Seward, of New York; continued from last Administration.

Secretary of the Treasury.

George Harrington, of the District of Columbia (Assistant Secretary), ad interim, March 4, I865.

Hugh MCCulloch, of Indiana, March 7, 1865.

SECRETARY OF WAR.

Edwin M. Stanton, of Pennsylvania; continued from last Administration.

Attorney-General.

JAMES SPEed, of Kentucky; continued from last Administration.

Postmaster-General.

William Dennison, of Ohio; continued from last Administration.

Secretary of the Navy.

Grdeon WeLles, of Connecticut; continued from last Administration.

SeCRETARy OF THE INTERIOR.

JoHN P. Usher, of Indiana; continued from last Administration. 


\section{LINCOLN.}

There is a dramatic story, which owes its authority to Gideon Welles, that Lincoln thought out the personnel of his Cabinet, during the wakeful hours that followed his departure, in the early morning of Wednesday, November 7, 1860, from the little telegraph office at Springfield, where he had awaited the returns from the elections. ${ }^{2}$ The fewness and directness of the strokes with which he afterwards accomplished the task, that under the circumstances was nothing less than colossal, also point to an early and thorough grasp of the principles upon which his administration should be made up. For, from the time when he began his definite arrangements, early in December, until their completion, the day after his inauguration, the only matter of serious doubt was what representation could be given to the South.

One of the rules that he fixed upon was to divide the Cabinet as equally as might be between the old Whigs and Democrats, in recognition that the Republican party was a fusion. Another was to bind together the several personal factions by taking his competitors for the presidential nomination to be his official advisers. The former geographical code was to be changed, only as the dismembered condition of the Union should render impossible the proportional representation of the slave interest; though it was evident that the modification would have to be a great one.

Those of Mr. Lincoln's rivals who had shown the strongest support were William H. Seward of New York, Simon Cameron of Pennsylvania, Salmon P. Chase of Ohio, all of them members of the United States Senate, though Chase had more recently been Governor of his State, and Edward Bates of Missouri, a prominent figure in Western politics. Of these Seward and Bates had been previously Whigs, Cameron and Chase, Democrats. So soon as Mr. Lincoln was apprized of his nomination, he had settled upon Seward

${ }^{1}$ Atlantic Monthly, CIII, No. 2; Diary of Gideon Welles. 
and Bates for members of his Cabinet; and had assigned to $\mathrm{Mr}$. Seward, by virtue of his political seniority and his long and varied experience of public affairs, the State Department. He made the formal tender by a letter of December 8 , I860, and shortly received an acceptance, Mr. Seward himself not visiting Springfield, though his representative, Thurlow Weed, duly appeared there in the throng of Cabinet makers. On the I8th, Mr. Bates, whom the President-elect had approached in a peculiarly complimentary way, visited Springfield in person; and was given authority to publish in the Missouri Democrat that he would be offered and would accept a place in the new Cabinet, though the particular post was not yet determined.

Meanwhile politicians were circulating the report that the new President would, in view of the peculiar situation, include among his official advisers, several of his political enemies, and Mr. Lincoln sought to quiet this by inserting a pointed editorial in the Illinois Journal of December I2: "We hear such frequent allusions to a supposed purpose on the part of Mr. Lincoln to call into his Cabinet two or three Southern gentlemen from the parties opposed to him politically, that we are prompted to ask a few questions. First, is it known that any such gentleman of character would accept a place in the Cabinet? Second, if yea, on what terms does he surrender to Mr. Lincoln, or Mr. Lincoln to him, on the political differences between them; or do they enter upon the administration in open opposition to each other?"

Pennsylvania was again asking for the Treasury; and various considerations pointed to Simon Cameron as the most suitable representative of that State. Mr. Cameron was bidden to Springfield, and on December 3I, departed from there with a written statement that he would be nominated either for Secretary of the Treasury or Secretary of War, the indefiniteness being due to Mr. Lincoln's own inclination towards Governor Chase for his Minister of Finance. This engagement proved to be a most embarrassing one; for three days after it was made, Mr. Lincoln was constrained to withdraw the offer and hold the Pennsylvania appointment open. On the day of Cameron's departure, moreover, Mr. Chase had been summoned to Springfield, where Lincoln made certain propositions regarding the 
Treasury with accompanying explanation that Mr. Seward was to be Secretary of State. However, he made no engagement with Chase, which seems to indicate that he shrank from too great haste in setting over against each other those two great men, differing as they did in temperament and political antecedents, and giving promise of rivalry for future preferment.

Though not giving his confidence to his prospective Secretary of State in such measure as some Presidents-elect have done, he was in correspondence with him, especially upon the subject of finding representative Southern gentlemen, identified with the slave interest, whom layalty to the Union might render eligible to a place in the National Executive; a project which was especially attractive to Mr. Seward. In this correspondence were considered Randall Hunt of Louisiana, John A. Gilmer and Kenneth Raynor, both of North Carolina, and Robert E. Scott of Virginia. Up to the close of January, strong hopes were entertained of an arrangement with $\mathrm{Mr}$. Gilmer, but it was a very serious difficulty that that gentleman advocated the extension of slavery in the Territories, and he moreover advised that the President-elect should seek to ingratiate himself with the South by means of a published letter defining his position, which expedient Lincoln viewed as a practical apology for having been elected. Mr. Gilmer declined to visit Springfield; and no further attempt was made to find a Cabinet Minister south of the border slave States.

Lincoln had early settled in his own mind upon Gideon Welles of Connecticut to be the member from New England. Mr. Welles was a man of advanced years, and an old time Democrat, who had latterly enjoyed no particular influence in his section. In Jackson's time, he had held office under the government of his State, and Polk had made him the head of a bureau in the Navy Department. It was for the Navy portfolio that he was now slated. The choice was appropriately referred to one of the Senators from Connecticut, and to the Vice-President-elect, Hamilton Hamlin of Maine, and others, who confirmed it. Between Lincoln and Hamlin, there was a personal interview at Chicago, two weeks after the election, that was the occasion of Cabinet discussion. 
Meanwhile, politicians from Indiana were not slow to wait upon the President-elect; for in the new geographical adjustment, that State had appeared upon the list of those that an administration must reckon with. Two "favorite sons" were urged for the Cabinet, Schuyler Colfax and Caleb B. Smith, the former a member and the latter an ex-member of the House of Representatives. Mr. Smith was decided upon for the Interior Department, being preferred, as Lincoln graciously wrote his competitor, for his more advanced years, which left him little prospect of a career in the future.

Of these several arrangements, only those with Seward and Bates were complete, when Lincoln arrived at Washington, February 23. Chase and Smith were under advisement; and Welles had not yet been approached. An engagement with Pennsylvania had been broken off, while nothing had been accomplished towards finding the seventh member, who, as it was determined, was to come from a loyal slave State. In perfecting his arrangements, Mr. Lincoln renewed his offer of the War Department to Cameron, with tactful explanation that he no longer regarded the objections which had been raised as vital; and Mr. Cameron accepted. The general plan of the new administration was almost broken in two, however, by the selection of the Postmaster-General. This portfolio was assigned to Maryland, where Winter Davis was passed over in favor of Montgomery Blair, son of Frank P. Blair, former editor of the Globe, and brother of Frank P. Blair, Jr., who was to attain some prominence as a Republican Congressman from Missouri, and as a General in the Union Army, the reason for the preference being that Mr. Davis had formerly been a Whig, while Mr. Blair preserved the traditions of the Jackson Democrats. It is said that this decision, whereby the odd portfolio went to the former Democrats, was one of the occasions when Mr. Lincoln remarked that he himself had been an old line Whig, and would always be present to make the parties even. ${ }^{2}$ But the prospective Secretary of State, Mr. Seward, had been accumulating a bundle of grievances of which this was the last straw. The closing of the arrangement with Chase threatened his own hoped for supremacy in the administration, and in his misconception of how the

${ }^{2}$ Nicolay and Hay, Abraham Lincoln, III, 369. 
Cabinet was to be operated, he assumed that with four portfolios in the hands of Democrats, and only three in the hands of Whigs, the Secretary of the Treasury would outweigh him. On March 2, he entered a request to withdraw his acceptance of the State Department; and Lincoln was far enough from truckling to him to say: "When that slate breaks again, it will break at the top." Other Presidents have been left in the lurch at the last moment; but none have emerged so triumphantly as Lincoln. On the day of his inauguration, he pressed upon Seward, both by correspondence and interview, the plea that the public service needed him; and the following day the resignation was recalled. Accordingly, on March 5, the nominations were made and confirmed with feeble opposition to Blair and Bates.

The new President had had extraordinary success in combining in seven men requisites of locality, influence, and political antecedents with a very high order of training and ability; but he had brought together such varying personalities and conflicting temperaments that the most tactful control was necessary. Nicolay and Hay remark that in weaker hands than Lincoln's such a Cabinet would have proved a hot-bed of strife, while under him, it became a tower of strength. But, according to the lively disclosures of Gideon Welles' Diary, it did not fail of being a hot-bed of strife also.

It is impossible to appreciate the difficulty with which men in public life in $186 \mathrm{I}$ came to understand that a man, who was but recently a second rate Illinois lawyer, had suddenly become the real Chief Magistrate of the United States. And it was favorable to misconception that Lincoln showed more than ordinary deliberateness, while he discussed with the Cabinet and the head of the army the situation at the Southern harbors. After the administration had lagged a month, Seward was convinced that the Government needed a Prime Minister, and opened formal arrangements for assuming that role. There are very few instances in which Cabinet officers have been bold enough to make formal demands of their chief; and this proposition that the President vest the general functions of his office in the Secretary of State stands by itself.

On April I, I861, Seward transmitted to Lincoln a paper bearing the title, "Some Thoughts for the President's Consideration." 
Premising that a month had passed without determining 11pon an administration policy, either domestic or foreign, he ventured to offer his own ideas. With little appreciation of what the "irrepressible conflict" had come to, he proposed a domestic policy that should divert the people from the question of slavery to a broader one of union and patriotism; while in the foreign field he would inaugurate an ambitious movement against European intervention, to the extent of convening Congress and declaring war on France, Great Britain, and Spain, unless satisfactory explanations could be secured of their designs in Mexico. The pith of the "Thoughts" is the Secretary's offer to assume the direction of "the administration." "Whatever policy we adopt, there must be an energetic prosecution of it. For this purpose it must be somebody's business to pursue and direct it incessantly. Either the President must do it himself, and be all the while active in it, or devolve it on some member of his Cabinet. .... Once adopted, debates on it must end and all agree and abide. It is not my special province, but I neither seek to evade nor assume responsibility."

The President promptly replied to all the points in respectful but decisive terms, disposing of the crucial question as follows: "Upon your closing propositions I remark that if this must be done, I must do it. When a general line of policy is adopted, I apprehend there is no danger of its being changed without good reason, or continuing to be a subject of unnecessary debate; still upon points arising in its progress I wish, and suppose I am entitled to have, the advice of all the Cabinet."

This remarkable overture did not go beyond Lincoln's knowledge; and the tactful rebuff served to orient the Secretary of State as to his relation to the President. Nevertheless, Seward sometimes improved the opportunities for overstepping Departmental bounds, which the inordinate stress of business afforded. A familiar instance is his ordering an expedition to Pensacola, without the previous knowledge of the War and Navy Departments; on which occasion the President admitted that he had signed a number of papers without being aware of their contents, but asked what he was to do,

${ }^{8}$ Nicolay and Hay, Abraham Lincoln, III, 445. 
if he could not trust the Secretary of State." Another is his communication to the British Legation that the mails carried by captured merchant vessels would not be searched. ${ }^{5}$ However, more than ordinary confidence was reposed by Lincoln in his Secretary of State, which resulted from the fact that Seward was in better accord than any of his colleagues with the President's individual views, and was assisted by the circumstance of his residing near the White House. At Seward's death his eulogist, Charles Francis Adams, regarding the Lincoln administration from a diplomat's point of view, asserted that the Secretary of State had been the real head of the Executive. The surviving members of the Lincoln Cabinet, Gideon Welles and Montgomery Blair, published a reply to Mr. Adams, in which they assigned to their late colleague a place of sufficient subordination to their common chief to satisfy any qualms of jealousy that his real priority in Lincoln's counsels might have aroused.

Before the first year of the administration had passed, Secretary Cameron of the War Department was superseded by Edwin M. Stanton, who showed himself comparable with Seward and Chase as one of the administration forces.

The issue of Cameron's appointment to the War Office had been that the Department was virtually put in commission for the next nine months, its appropriate duties being shared by the Secretaries of State and the Treasury. The Department was infested with secessionists like the others, and it had fallen into a particularly bad condition through the misconduct of Secretary Floyd; moreover, it was the first to feel the demands of the Civil War. To these Cameron proved quite inadequate; and much of the work of organizing troops devolved upon Chase, ${ }^{8}$ while military arrests were put within the competence of Seward. Furthermore, scandals arose concerning contracts in both the War and Navy Departments; and an investigation by Congress resulted in Cameron's censure, though this was

${ }^{4}$ Welles, Lincoln and Seward, 68, 70.

${ }^{5}$ Atlantic Monthly, CIII, No. 5; Diary of Gideon Welles.

${ }^{6}$ Charles Francis Adams, Address on the Life, Character, and Services of William H. Seward.

'Gideon Welles, Lincoln and Seward.

${ }^{8}$ Hart, Salmon P. Chase, $2 \mathrm{Ir}$. 
afterwards recalled with Lincoln's approval. However, the Secretary of War in his Annual Report overstepped his authority by advocating a policy in which the President was not prepared to sustain him, viz., the arming of fugitive negroes, and by giving the report for publication, before it had been censored; whereupon the President's order that the paragraph be retracted caused much embarrassment. This combination of difficulties, in which incompetency probably had the greatest weight, caused Lincoln to rid himself of Cameron as a Secretary and Cabinet officer, in January, 1862, the dismissal being softened by the tender of the Mission to Russia, which Cameron did not want, but accepted for a short time $;^{\circ}$ and further mitigated by the publication of a more complimentary correspondence on the subject than the one that had actually passed. ${ }^{10}$

In his dealing with Cameron, Lincoln had shown great power to avoid giving offence; but he showed equally great superiority to taking it, when he called Stanton into his service. Mr. Stanton had not allied himself with the Republicans in the presidential election. Moreover, the whole tone of his correspondence during the first months of the administration and the early repulses to the Union arms had been one of contempt for Mr. Lincoln. A specimen may be found in one of his letters to ex-President Buchanan, written after the defeat at Bull Run: "It is not unlikely that some changes in the War and Navy Departments may take place, but none beyond those two Departments, until Jeff Davis turns out the whole concern. .... While Lincoln, Scott, and the Cabinet are disputing who are to blame, the city is unguarded, and the enemy at hand." "Stanton's biographer, Gorham, extenuates these expressions as mere examples of the great Secretary's hasty temper and abrup.t speech. Lincoln was probably aware that he was not regarded with approval by the man whom he selected for so great a trust; but he, of all Presidents, was best able to overlook personal considerations for the sake of the public interest. There was much to recommend Mr. Stanton for

${ }^{\circ}$ Nicolay and Hay, Abraham Lincoln, V, I27.

${ }^{10}$ Rhodes, History of the United States, III, 576; McClure, Lincoln and the Men of War Times, I50.

${ }^{11}$ Gorham, Edwin M. Stanton, I, 223. 
the office in question. His energetic services at the crisis of the last administration had won him great prestige. He had shown himself a supporter of the Union. Furthermore, he satisfied the same requirement of locality as his predecessor, being a Pennsylvanian. The credit for selecting Stanton was claimed by several of the Cabinet officers, including Cameron himself, which presumably means that Lincoln made previous mention of the appointment to two or three of them. Such surprise was caused in the Senate at the naming of a member of the late administration for Secretary of War, that the nomination was referred; and Secretary Chase, of whom the committee sought an explanation, was prepared to recommend that $\mathrm{Mr}$. Stanton be confirmed.

In the second year of the Lincoln administration, there occurred the most significant attempt to dictate the Cabinet relations and procedure by Congressional interference that the history of the Government affords. A variety of facts entered into the situation which prompted this. The war had not been successfully prosecuted; General McClellan's command had been especially futile; and there was a disposition to charge the disasters to the Executive mismanagement. The Cabinet as a council had not been sufficiently in evidence to satisfy those members of the Government who thought that the existing crisis demanded increased consultation rather than the opposite. His military counsels President Lincoln was disposed to hold with a few chosen officers of whom the Secretary of War and the General-in-Chief of the Army were the principals; not even the great army appointments were referred to the Cabinet with any regularity.

The President was furthermore disposed to emphasize the separate character of the Department Heads over the collective in meeting the unprecedented demands of the Government upon the Executive. Thus it was only the President, much of the time, that listened to the despatches of the Secretary of State $;^{12}$ and in similar fashion, the business of the Treasury was despatched. ${ }^{13}$ The result was a somewhat irregular existence for the Cabinet council, and it began to be

${ }^{12}$ Fessenden, Wiliam Pitt Fessenden, I, 242.

${ }^{13}$ Hugh McCulloch, Men and Measures of Half a Century, 199. 
said that there was " no Cabinet" and " no administration in the proper sense," a charge Secretary Chase was largely responsible for. Representing the opinion of the radical Republicans, that the extermination of slavery should be immediate, and not made to wait upon the preservation of the Union, Chase was at variance with the dilatoriness of the administration. Further than this, in his consciousness of the good military judgment which he had demonstrated during Cameron's incumbency of the War Office, and his intolerance of Lincoln's unmethodicalness, he conceived of a Directory, in which the Department Heads should regularly confer with President and Generals as the corrective for the mistakes which the Executive was making. The majority of the government party in the Senate shared the Secretary's views; among others, Secretary Fessenden, chairman of the Committee of Finance, was in substantial accord with him; and the situation was favorable to the dissemination of Mr. Chase's criticism of Executive operations.

On the other hand, the conservative opinion in the party was represented by the President himself, and the Secretary of State; which concurrence was highly favorable to the preconceived notion, that while Mr. Lincoln was the titular President, Mr. Seward would be the actual one. Accordingly as the administration became unpopular, the Secretary of State incurred much of the blame. Attendant upon this was an almost inexplicable loss of the political favor which $\mathrm{Mr}$. Seward had enjoyed. His popularity with the Senate was over; a few conservative utterances during the Congressional session that preceded Lincoln's administration had cost him the confidence of Senator Fessenden; and certain despatches of the summer of 1862 , had been especially offensive to Sumner, who as chairman of the Committee of Foreign Relations stood in the same official relation to him as Fessenden to Chase. Even the support of his own State was uncertain.

The defeat of General Burnside at Fredericksburg in December, I86,2, served the Senate as a signal for action; and all of the Republican members, with the exception of one of the Senators from New York, joined in a demand for the removal of the Secretary of State. At caucuses held on successive days, December 16 and 17 , the dis- 
integrated condition of the Cabinet council was discussed, resolutions were passed recommending a partial reconstruction of the Cabinet, and a committee was appointed to present to the President the demand of the parties assembled for changes both in the conduct and the personnel of the Cabinet. There was even a suggestion that the demand be made official by introducing a resolution in the open Senate. The committee included Senators Collamer, Wade, Grimes, Trumbull, Sumner, Harris, Pomeroy, and Howard. Mr. Collamer had himself been a Cabinet officer; and his assertion in caucus that the theory and practice of the Government demanded a Cabinet council and that it was unsafe and wrong to leave each member to his own Department, probably indicates that President Taylor, ineffective as his Cabinet was, had kept up the forms of general consultation. Collamer's statement was incorporated in a paper which he prepared to submit to the President. Another clause was to the effect that the Cabinet should be exclusively composed of statesmen who were the cordial, resolute, and unwavering supporters of the vigorous prosecution of the war, and was plainly directed against Secretary Seward. President Lincoln accomplished one of his master strokes in his treatment of this demand from the Senate. After a preliminary hearing on December I8, the spirit of which was on the whole derogatory to the attitude of the Senators, he brought on the Igth, Committee and Cabinet face to face. Seward, who had tendered his resignation upon information from Senator King of New York, was absent. The first result of the interchange of charges and answers that ensued, was a backing down on the part of Chase, who maintained that questions of importance had generally been considered in the Cabinet, though, perhaps, not so fully as might have been desired, and that there had been no want of unity but a general acquiescence on public measures. On the 2oth, Chase followed Seward with a resignation. He had had an interview with the Secretary of State; but his reasons for resigning, as he expressed them to one of his Senatorial friends, were the fear that he might be accused of manœuvering to get Mr. Seward out, if he himself remained, since the two had been appointed as representing different wings of the party, and doubt as to whether he could manage the 
Treasury Department, which was difficult at best, if he had the disaffection of Seward's friends to contend with. ${ }^{14}$ Upon receipt of $\mathrm{Mr}$. Chase's resignation, Mr. Lincoln announced that he should accept neither; both Secretaries resumed their posts; and the only result of this extraordinary episode, so far as Cabinet affairs were concerned, was the fuller subjection of both Seward and Chase to the President's control.

The biographers who have written up this episode naturally emphasize its bearing upon the relations between the two rival Secretaries and the President, though they do not agree in their construction of it. Thus, Nicolay and Hay, who are quite unfair to the radical elements in the Government, represent the Senatorial interference merely as an attack upon the Secretary of State fomented by the Secretary of the Treasury, which covered the latter with confusion, and attested President Lincoln's power to reduce contending factions to his control. ${ }^{15}$ Professor Albert Bushnell Hart, quoting the Memoirs of Major Wright Bannister, represents that the two Secretaries, in this particular transaction, were acting together. ${ }^{16}$ For our purpose the great significance of the affair lies in its being a well considered attempt by the whole Government party in the Senate to act as a superior council, in dictating the procedure as well as the personnel of the Cabinet. Indeed, Mr. Fessenden, when called upon to state his complaints before the President, prefaced his charges of lack of general consultations and undue influence from a single Department, with saying that the Senate, "as Constitutional advisers of the President" had deemed the emergency serious enough to offer their friendly counsel.

The restiveness and uncertain loyalty of Secretary Chase as an Executive subordinate worked the most serious friction that arose within the administration. Perfect concord between Secretary and President was prevented, in the first place, by their different views of the administration problem; they had different conceptions also of the nature of the Executive, or rather of the way it ought to

\footnotetext{
${ }^{14}$ Fessenden, William P. Fessenden, I, 231-253.

${ }^{15}$ Nicolay and Hay, Abraham Lincoln, VI, 264-27I.

${ }^{16}$ Hart, Salmon P. Chase, 302.
} 
operate in a great war; and still further, their personal incongruities were too great to be well harmonized.

The chief subject that brought Chase into actual conflict with his superior was that of presidential appointments within the Treasury Department. The Secretary took the stand that, for the sake of efficient service, his recommendations as head of the Department, must prevail over those of the representatives of the localities interested; while the President was inclined to consider local preferences, as a means of conciliating feeling towards the Government. On this subject a series of differences arose, in which Chase resorted to the peevish expedient of resigning his office, as a means of carrying his point. The first controversy, which occurred in March, 1863, concerned an internal revenue collectorship in Connecticut, about which the Secretary came into collision with one of the Senators from that State; the difficulty was quieted by a personal conference arranged by the President. The second, which followed three months later, related to a collectorship of customs on Puget Sound; the collector had been appointed as a favor to Chase, but had proven his incompetency, whereat the President, yielding to pressure brought to bear by Congressmen from the Pacific coast, removed the officer, but conceded that the Secretary should name a successor. A third difficulty of the same sort grew out of a demand for the removal of the collector of customs, at New York, June, I864; though Lincoln approved of the existing incumbent highly enough to propose his transfer to the Mission to Portugal, he was inclined to gratify the local demand for the removal, but after conference with Chase, surrendered to his wishes and declined to make the change. Only a few days later occurred the final difficulty, which concerned the assistant treasurership at New York; the incumbent of that office desiring to resign, Chase urged for his successor a candidate to whom one of the New York Senators objected; this affair was settled by prevailing upon the existing Assistant Treasurer to continue in office. On the first of these occasions, Chase had written a resignation, but refrained from sending it; on the second he actually resigned, and required the most considerate persuasion from Lincoln to remain at his post; on the third occasion, 
when he fully carried his point, there is some indication that he threatened to resign; on the fourth occasion, he had written a resignation before the controversy was settled to his satisfaction, and sent it after his triumph. This the President accepted, July I, I864.

An additional factor in the strained relations between Lincoln and his Secretary of the Treasury was their rivalry for the presidential nomination of 1864 . While a general purpose to further his own interests probably inhered in Mr. Chase's habit of disparaging the existing administration, and in his practice of personally ingratiating himself in military and other quarters, he is not charged, even by his most severe critics, with dispensing the patronage in his own behalf. However, he was indirectly a party to a very great offence against the loyalty to his chief which custom required of him, by his share in the publication of the Pomeroy Circular. This was a campaign document put out in February, I864, which openly disparaged President Lincoln for his compromising disposition, and presented Secretary Chase as the one candidate who combined the qualities which the existing crisis demanded of a President. Chase partially exonerated himself for this act in his behalf, and intimated a willingness to resign from the Cabinet, if President Lincoln desired. Moreover, he publicly withdrew from his presidential candidacy in April, and on June 7, 1864, Mr. Lincoln received of the Republican National Convention a nomination for a second term of office. An additional unpleasantness had arisen, however, by the President's renewal of General Frank P. Blair's commission in the army, immediately after that gentleman, as Representative from Missouri, had made an attack upon the Secretary of the Treasury in the House of Representatives; though it was outwardly removed by Mr. Lincoln's explanation that he had resolved to renew the commission, before he heard of the speech derogatory to $\mathrm{Mr}$. Chase. In accepting the particular resignation, which followed the controversy about the assistant-treasurership at New York, Lincoln doubtless felt that the constant irritation had begun to impair Chase's efficiency; and that further temporizing would mean a greater surrender than the Chief Executive ought to make. Three 
months later, he nominated Chase to be Chief-Justice of the United States, and received the oath of office from him at his second inauguration. The Treasury portfolio was promptly offered to Governor David Tod of Ohio, who declined it; whereupon a literal impressment of a Cabinet officer occurred in the summary appointment of Senator William P. Fessenden of Maine. ${ }^{17}$

There is no stronger proof of Lincoln's power as a master of men than the loyal and efficient service which he commanded of Stanton as his War Minister; for it was this same Secretary that showed himself in the hands of Lincoln's successor, the most intractable of Cabinet officers. In spite of his previous disparagement of Lincoln, Stanton came to feel for him, as the two shared the anxieties of the war, the most loyal appreciation. That Lincoln promptly discovered how to get along with Stanton's peculiar disposition is not so strange. When the Secretary of War showed resistance to authority, it proceeded not so much from difference of views and temperament, as was the case with the Secretary of the Treasury, but from hastiness of temper, and stubbornness. Between Lincoln and Stanton, there were many cases of disagreement; which generally related to such questions as military pardons, privileges within the army lines, etc. Sometimes, indeed, the Secretary's severity was required to prevent the President's clemency from destroying discipline. It was an exasperating practice of Stanton's to refuse to sign orders which did not suit his judgment; and to scribble in place of his name the assertion that perhaps another man would sign the paper, but he would resign first. With this habit, Lincoln seems to have had three ways of dealing: viz., to persuade Stanton to affix his signature, to yield to him, or to let the matter in question proceed without written authority, and sustain the parties afterward. Perhaps the sharpest dispute was one that grew out of the President's order of September I, I864, relative to rebel prisoners at Rock Island, in which Stanton, after declaring against the execution of the order, for the third time, submitted to the President's will. ${ }^{18}$

The relative authority of President and Cabinet, is especially

\footnotetext{
${ }^{17}$ Fessenden, William Pitt Fessenden, I, 315-324.

${ }^{18}$ Nicolay and Hay, Abraham Lincoln, V, I42-I 47.
} 
hard to measure during the Civil War, because the functions of the whole Government were so greatly expanded. In large questions of policy, Lincoln was accustomed to consult the whole Cabinet, and to give abundant opportunity for suggestions. However, the Emancipation Proclamation has become proverbial as the crowning instance of a President's independence of advice. Lincoln resolved upon this measure, and drafted the instrument, before his official advisers knew of it, save that he had intimated his purpose to two of the Secretaries, a few days before he officially notified the whole Cabinet. However, he was not strictly breaking new ground, inasmuch as the subject of emancipation had been discussed off and on for a good many months. Besides, the Proclamation was made the subject of four Cabinet meetings, July 22 and 23, September 22, and December 30 , in the course of which the President agreed to postponement and rewrote the paper with changes, of which one or two were more than verbal. $^{19}$ On the whole the share of the Cabinet in this extraordinary exercise of the executive power was a very humble one, and there is probably no more marked case of a President's unaided initiative.

In his judgments of the state of the public pulse, Lincoln seems to have been especially independent. Those decisions of 1862 , in which his failure to take advice provoked criticism in Congress, were of this sort, the establishing of General Halleck at Washington to act as General-in-Chief, and the placing of the army under McClellan after his return from the Peninsula, being examples. Concerning the dismissal of Cabinet officers, he would no more brook the interference of Secretaries than of Senators ; and in July 1864, he administered a sharp rebuke to the whole Cabinet, when a demand was brought by hand of Secretary Stanton, for the removal of Postmaster-General Blair, because the latter officer had criticized certain army officers, in his indignation at the burning of his house and library during the attack upon Washington. ${ }^{20}$ While he seldom, if ever, decided a cardinal point against his own judgment, Lincoln was not superior to yielding his opinion, even in large matters, when he was not satisfied of its wisdom. Thus, in February, 1865, after

${ }^{19}$ Nicolay and Hay, Abraham Lincoln, VI, I23-I30; I58-164; 405-42I.

${ }^{20}$ Lincoln's Complete Works, II, 548. 
holding a conference with certain leaders of the secession at Fortress Monroe, Secretary Seward attending, he formulated a plan to indemnify the States in rebellion for their slave property, on condition of their ceasing from resistance to the National authority. Upon the unanimous disapproval of the Cabinet, the Message laying the project before Congress was withheld, and the plan abandoned. ${ }^{21}$

When Lincoln entered upon his second term of office the personnel of the Cabinet had been greatly changed; and, on the whole, not strengthened. Secretary Smith, never a conspicuous figure, retired from the Interior Department in December, I862, having been appointed to a District Judgeship ; and, after some delay, was succeeded by John P. Usher, who had been Assistant-Secretary of the Department, and, like his predecessor, represented the State of Indiana. In November, I863, Attorney-General Bates resigned, because as he stated it, he was "weary with the general revolutionary spirit, and tried with the continuous innovations upon law and precedent necessary to the war administration." The President, desiring to preserve the original geographical distribution, tried to find a successor to Bates in Missouri, but, failing of this, turned to Kentucky, and made a tender to Joseph Holt, who had served in Buchanan's administration, both as Postmaster-General and Secretary of War. Holt, however, declined; and Lincoln had to satisfy himself with James Speed, a lawyer without National reputation.

The retirement of Postmaster-General Blair was an incident of the presidential election of 1864 , and reveals Lincoln in the character of a politician. Blair had made an efficient PostmasterGeneral; but had been an administration thorn from the outset, both for his personal enmities and his constituency. Moreover, as factional differences waxed warmer with the discontent about the war, Blair became the special target of the Radicals. The Radical Republicans nominated General John C. Fremont for the Presidency; while the Union Republicans nominated Lincoln, but put a resolution into their platform that was aimed against the ultraconservative element in the Cabinet. In September, I864, when the issue of the election seemed especially doubtful, Lincoln called for

${ }^{21}$ Lincoln's Complete Works, II, 636 . 
Blair's resignation, and it was cheerfully tendered. ${ }^{22}$ William A. Dennison of Ohio, was immediately appointed Postmaster-General. In January, I865, Secretary Fessenden was reelected to the Senate, which he preferred to the Treasury. The candidates recommended to the President for the vacant portfolio were Governor E. D. Morgan of New York, Governor John A. Andrew of Massachusetts, Vice-President Hannibal Hamlin of Maine, and Hugh McCulloch of Indiana, Comptroller of the Currency. Lincoln first nominated Governor Morgan, who was supported by the conservative Republicans of New York; upon Morgan's refusal to accept, he appointed Hugh McCulloch who was the choice of Jay Cooke and the Chicago bankers. It was a part of the understanding that Secretary Usher would retire from the Interior Department to avoid the double, representation of the State of Indiana; and James Harlan, Senator from Iowa, was selected to succeed him, though this change had not been accomplished at the President's death. Thus the Cabinet which Lincoln left to his successor was composed of Seward, McCulloch, Stanton, Speed, Welles, Dennison, and Usher, of whom Seward and Welles were the only survivors of the original group.

${ }^{22}$ The attempt of Lincoln's friends to deprive the incident of its political meaning is hard to harmonize with the order of events. August 23, Lincoln wrote in a memorandum that it seemed probable that he would not be reelected. Fremont's withdrawal from his candidacy was already under discussion. September I, and again on the $3 \mathrm{~d}$, Lincoln summoned Blair to return to Washington immediately. September 2I, Fremont actually withdrew; and on the 23d, Lincoln called in writing for Blair's resignation, accompanying the request with a letter of commendation for his services. 
President.

ANDREW JOHNSON, Tennessee.

President Pro Tempore of the Senate.

LAFAYETTE S. FOSTER, Connecticut.

BENJAMIN F. WADE, Ohio.

April 15, I865, to March 4, I869.

Secretary of State.

William H. SewARd, of New York; continued from Lincoln's Adminis. tration.

Secretary of the Treasury.

Hugh McCulloch, of Indiana; continued from Lincoln's Administration.

Secretary of War.

Edwin M. Stanton, of Pennsylvania; continued from Lincoln's Administration.

Ulysses S. Grant, (General of the Army), ad interim, August 12, 1867.

Edwin M. Stanton, ${ }^{1}$ of Pennsylvania; reinstated January 13, I868.

Lorenzo Thomas (Adjutant-General, U. S. A.), ad interim, February 2I, I868.

John M. Schofield, of Illinois, May 28, 1868.

\section{Atrorney-General.}

JAMES SPEED, of Kentucky; continued from Lincoln's Administration.

J. Hubley Ashton, of Pennsylvania (Assistant Attorney-General), acting, July I7, I866.

Henry Stanbery, of Ohio, July 23, I866.

Orville H. Browining, of Illinois (Secretary of the Interior), ad interim, March I3, 1868.

William M. Evarts, of New York, July 15, I868.

\section{Post Master-General.}

William Dennison, of Ohio; continued from Lincoln's Administration. Alexander W. Randall, of Wisconsin (First Assistant Postmaster-General), ad interim, July 17, 1866.

${ }^{1} \mathrm{Mr}$. Stanton did not cease to perform the duties of Secretary of War until their assumption by Major-General Schofield. 
SeCretary of the Navy.

Gideon Welles, of Connecticut; continued from Lincoln's Administration.

SECRETARY OF THE INTERIOR.

JOHN P. UsHeR, of Indiana; continued from Lincoln's Administration.

James Harlan, of Iowa, May 15, I865.

Orville H. Browning, of Illinois, July 27, I866, to take effect September I, I866. 


\section{JOHNSON.}

For more than a year, Johnson preserved Lincoln's Cabinet intact, save that Secretary Usher resigned from the Interior Department as previously arranged. The new President went so far as to appoint to the vacancy James Harlan of Iowa, the man of his predecessor's selection, and three of Lincoln's earlier appointees, Seward, $\mathrm{McCulloch}$, and Welles, he retained to the end of his administration. The explanation of this course, which is in bold contrast with that of Tyler in 184I, of Fillmore in 1850, and of Arthur in 188I, is, as Johnson's sympathizers asserted, that he sought to identify his policy of Reconstruction with the plan which was maturing in the minds of Lincoln and his advisers, and had been presented by the Secretary of War at Lincoln's last Cabinet meeting, April 14, I865. ${ }^{2}$ Furthermore in retaining his predecessor's Cabinet, Johnson resisted a pressure that is amazing both for its persistence and the respectability of its sources, and which can only be explained by the disintegration in the Republican party that followed the close of the War and the death of Lincoln. This agitation for a change of Cabinet began three days after Johnson's accession, ${ }^{3}$ and continued until the presidential nominations of I868 made the existing administration a matter of minor interest.

Among the President's advisers, the most notable were Thomas Ewing, a former member of two Whig Cabinets, and Frank P. Blair, Sr., administration editor to Jackson and Van Buren. These two men, now advanced in years, loom up among Johnson's correspondents as preservers of party traditions by which the accidental President, in his ill-defined political position, might be expected to

${ }^{2}$ Gideon Welles, Lincoln and Johnson in the Galaxy, vol. I3, pp. 521-532; $663-674$.

${ }^{3}$ Johnson MSS., J. L. Dawson to Johnson, April 17, I865; New York State Committee of the War Democracy to Johnson, April 2I, I865. 
profit. Duff Green also reappeared on the scene; though his timely suggestions as to how the new President might succeed himself in I869 did not contemplate a change of Cabinet."

Ewing and Blair alike approved of Stanton's removal, Ewing's name appearing at the head of a petition for that purpose, that was presented between the first and second sessions of Congress. ${ }^{5}$ Moreover, General Frank P. Blair, son of the elder Blair, pushed hard for Stanton's place, while the other son, Montgomery Blair, who had acquiesced in his own dismissal from the Postmaster-Generalship, to further Lincoln's reelection, now came forward to even up scores by decrying both Stanton and Seward, and was furthermore recommended by his friends for reinstatement. ${ }^{8}$ If pressure is ever sufficient cause for a Cabinet removal, Johnson would have been justified in dismissing Stanton at any moment from his accession to the passage of the Tenure-of-Office Act. The personal unpopularity of the Secretary of War was voiced at the outset both from military and other quarters; and in due time were added charges of consorting with the President's enemies.

There might also have been reason for dispensing with Seward; since it was charged at first that he and Weed were manipulating New York against the President, and later that he was an "effete body " and a " dead weight," the decline of whose political following made it impossible for him to lend prestige to the administration."

The actual changes in the Cabinet began in July, 1866, when Attorney-General Speed, Postmaster-General Dennison, and Secretary Harlan, in terms of doubtful cordiality, resigned their offices, being disaffected towards the President's Reconstruction policy. Of these resignations, Seward wrote: "The Cabinet, which has been

"Johnson MSS., Duff Green to Johnson, June 25, 1865.

J Johnson MSS., September I6, 1866.

'Johnson MSS., Jas. S. Rollins of Missouri to Johnson, June 7, I865; David Dudley Field to Johnson, June 8, r865.

"Johnson MSS., Montgomery Blair to Johnson, June 15, I865.

${ }^{8}$ Johnson MSS., N. D. Sherry, Secretary of National Union Committee to Johnson, May 4, 1865.

' Johnson MSS., Samuel Barlow to Montgomery Blair, June, I865; Montgomery Blair to Johnson, April II and August 9, I866. 
JoHNSON.

held so long together is at last struck, and begins to go apart. I regret it. Cabinets seldom separate for the good of the country, if they are made up of loyal men as this one has been. I part with Mr. Dennison and Mr. Speed with regret. The times require great firmness and coolness on the part of the Executive. It does not surprise, although it pains me, that all of my associates have not been able to see it their duty, as I see it mine, to sustain him." Secretary Harlan promptly returned to the Senate where he had resigned his seat the year before to accept the Interior Department; and in the impeachment trial, he voted for the President's conviction.

The new appointments were Henry Stanbery of Ohio, AttorneyGeneral; Alexander W. Randall of Wisconsin, Postmaster-General; and Orville H. Browning of Illinois, Secretary of the Interior. Stanbery and Browning, both of Whig antecedents, were warmly recommended by Ewing for ability and political character; while Randall's appointment was a promotion from the position of First Assistant in the Department. All of these proved loyal supporters of the President. Indeed the Attorney-General's opinions reflected the President's point of view so strongly that Congress by the supplementary Reconstruction Act of July 19, 1867, sought to limit their effect by forbidding the commanders of the military districts into which the States lately in revolt had been organized to be bound by "any opinion of any civil officer of the United States." Mr. Stanbery resigned his office to become one of the President's counsel in the impeachment trial; and when renominated, failed of confirmation.

According to the normal conception of a Cabinet officer's relation to the President, Stanton should have resigned, at least as early as the end of the Congressional session I865-'66; inasmuch as his disaffection with the administration policy was determined, according to his biographer, in the preceding September. The Secretary of War and his friends, however, seized upon the idea of the Cabinet as a check or safeguard against a wayward President, making a greatly aggravated case of the relation which the Harrison Cabinet attempted to establish with Tyler. Accordingly, he stuck to his 
post in behalf of the general welfare. ${ }^{10}$ That Johnson did not dismiss him between the adjournment of Congress in 1866 and the passage of the Tenure-of-Office Act is an enigma; though it is entirely supposable that the President did not appreciate the extent of the antagonism; he certainly was not aware of Stanton's participation in the framing of certain radical legislation. ${ }^{\text {11 }}$ Moreover, we find no act of real and open defiance before June I8 and 19, I867, when the Secretary of War, dissenting from the rest of the Cabinet, entered written protests against the opinions of the Attorney-General on the Reconstruction Acts.

The Tenure-of-Office Act of March 2, I867 is of signal importance, because it was potential of a radical change in the nature of the Cabinet; yet it loses very much of its significance, for the reason that it was a spasmodic and avowedly temporary measure. Hereby, the power to remove the Heads of Departments was so limited by the Senatorial concurrence that the means by which the President had heretofore kept his privy council in subordination was practically vitiated. The main provisions of the act were that the President might suspend an officer in the recess of Congress; that he should report each suspension to the Senate, together with his reasons for making it, within twenty days after the subsequent assembling: that if the Senate should concur, the President might then remove the officer and appoint another in the usual way; that if the Senate did not concur, the suspended officer should resume his duties. ${ }^{2}$

That this poor substitute for the time-honored power of removal should extend to the Cabinet, was a more drastic proposition than Congress was prepared to entertain, when the act first came before it, early in the session of 1866-'67. Though bent upon taking the patronage out of the President's hands, it was still bound by the idea of a special relation between the Chief Executive and his confidential advisers, which ought not to be interfered with. As the

${ }^{10}$ Gorham, Edwin M. Stanton, II, 300.

${ }^{11}$ Dewitt, Impeachment of Andrew Johnson, 267.

${ }^{12}$ Salmon, The Appointing Power of the President, 91-93; Fish, The Civil Service and the Patronage, 193-202. 
bill left the Senate, it read, "That every person (excepting the Secretaries of State, of the Treasury, of War, of the Navy, and of the Interior, the Postmaster-General, and the Attorney-General) holding any civil office to which he has been appointed by and with the advice and consent of the Senate, and every person who shall hereafter be appointed to any such office, and shall become duly qualified to act therein, is, and shall be entitled to hold such office until a successor shall have been in like manner appointed and duly qualified, except as herein otherwise provided." During the debate in the Senate, a motion to strike out the exception had been twice offered and twice defeated, the first time without a division, and the second by a vote of 23 to I3. It is an interesting fact that the author of this motion was Timothy $\mathrm{O}$. Howe, of Wisconsin, inasmuch as that gentleman afterwards served as Postmaster-General under President Arthur. However, when the House of Representatives took up the bill, two months of the session had passed, and the hostility to the President had become aggravated. The great Military Reconstruction Act was pending, and the Secretary of War was distinctly assuming the role of agent and guardian of the Congressional policy. The Tenure-of-Office Act was accordingly amended by striking out the Cabinet exemption, though the motion was lost on the first trial, and on reconsideration, carried by a bare majority of 63 to $67 .^{13}$ The Senate at first adhered to its original stand, and refused to concur in the amendment, by a vote of 28 to I7. It is interesting to discover at this point John Sherman, Secretary of the Treasury under Hayes, and a prominent aspirant for the Presidency in I880, as the principal champion of the President's personal right to a choice of his Cabinet. Apropos of the amendment, Sherman said: "It is a question with me, not of constitutional law, but a question of propriety. ... . I would as soon think of imposing upon the President a private secretary with whom he had no kindly relations, personal and political, as to impose upon him a Cabinet Minister with whom his relations were not kind. .... Any gentleman fit to be a Cabinet Minister, who receives an intimation from his chief that his longer continuance in that office is unpleasant to him, would

${ }^{13}$ Congressional Globe, 39th Congress, 2d session, 937, 943-4, 970. 
necessarily resign. If he did not resign it would show he was unfit to be there." The bill was referred to a joint committee; the Senate was represented by Sherman, Charles R. Buckalew of Pennsylvania, a supporter of the President, and George $\mathrm{H}$. Williams of Oregon, who was afterwards Attorney-General under Grant; while Robert Schenk of Ohio, Thomas Williams of Pennsylvania, and James F. Wilson of Iowa, represented the Lower House. This committee inserted in the bill, in the place of the Cabinet exemption, a proviso to the effect " that the Secretaries of State, of the Treasury, of War, of the Navy, and of the Interior, the Postmaster-General, and the Attorney-General shall hold their offices respectively for and during the term of the President by whom they may have been appointed and for one month thereafter, subject to removal by and with the advice and consent of the Senate." The application of this to the existing Secretary of War was by no means clear. This officer was the appointee of President Lincoln, his commission dating from January I5, I862. The President's Constitutional term of four years, within which this appointment had been made, terminated March 4, I865; but it had been renewed by reelection. Then Lincoln had died in office; and the remnant of the second period of four years had fallen to Johnson. Did the expression "term of the President," when applied to the Lincoln appointees, mean the Constitutional term within which the appointment occurred? And did Johnson's retention of Stanton constitute a reappointment? Or had the law no application to the Secretary of War?

The conferees for the House of Representatives reported that they had carried their point. Of the Senators, only Sherman and Williams agreed to the report, Williams on the ground that Cabinet removals would be precluded by the resignation of such officers upon the President's request, and Sherman for the additional reason that the provision did not hamper the power of a President to dismiss the Ministers selected by his predecessor. When Sherman voted for the conviction of President Johnson, he took his ground upon a different class of Cabinet regulations to be noticed in due order. His interpretation of the Tenure-of-Office Act appears to have 
been decisive in securing its adoption in amended form by the Senate; though that body acted with great inadvertency, if not insincerity.

The President now determined to make a test case, and have the Tenure-of-Office Act pronounced upon by the Supreme Court. His declaration of this purpose to the Senate in his special message of February 22, 1868, is sufficiently borne out both by the developments in the trial proceedings, and by private correspondence. ${ }^{14}$ August 5, 1867, Congress not being in session, the President wrote to the Secretary of War that his resignation would be accepted; to which the latter promptly replied that public considerations of a high character constrained him not to resign before the next meeting of Congress. On the I2th, the President notified the Secretary that he was suspended from office, basing the action upon the "power and authority" vested in himself " as President, by the Constitution and laws of the United States." At the same time, he designated General Grant to act as Secretary of War ad interim. It appears, moreover, that if Grant had consented, the President would have issued to him a vacation commission, thereby removing Stanton, in direct challenge to the Tenureof-Office Act. December I2, a few days after reassembling, the Senate was notified of Stanton's suspension, with causes, and after taking a month to deliberate, resolved January I3, by a vote of 35 to 6, thirteen Senators not voting, not to sustain the President. On the following day General Grant quitted the War Office, and Secretary Stanton resumed possession. Meanwhile Thomas Ewing, bent upon extricating Johnson before it was too late, had been urging the nomination of J. D. Cox of Ohio, in the belief that the Senate would promptly confirm it, and thereby avoid a direct vote upon Stanton. Indeed it seems to have been due to Ewing's advice that the suspension had been reported within the time stipulated by the Tenure-ofOffice Act, thus keeping the affair within the letter of the law. The President, having failed of the assistance of General Grant, sought that of General Sherman, making to him, on January 25, and again on

${ }^{14}$ Impeachment of Andrew Johnson, I, 680; Johnson MSS., Johnson to Grant, January 3r, r868; Jerome B. Stillson to Benjamin R. Curtis, April 4, I868. 
the 3 oth, a tender of the War Department ad interim. ${ }^{15}$ But Sherman would not enter into the controversy, and Ewing, who was his father-in-law, was not favorable to the arrangement. Moreover, the latter now urged the President not to remove Stanton. The President next approached General George H. Thomas to assume the duties of Secretary of War ad interim, and failed in that quarter. He then fell back on Lorenzo Thomas, Adjutant-General of the Army. February 2I, he notified Stanton of his removal from the office of Secretary of War, and issued to Thomas a letter of authority to act as Secretary of War ad interim, notifying the Senate of the action on the same day. On the $22 \mathrm{~d}$, that body responded with the resolution: "That under the Constitution and laws of the United States, the President has no power to remove the Secretary of War and to designate any other officer to perform the duties of that office ad interim." The vote on this occasion differed from that which reinstated Stanton, January I3, in that five Senators who voted against the suspension on that occasion refrained from voting, as the matter became more serious. The resolution immediately called forth from the President a message stating at length upon what legal grounds he based his action, including the following argument:

"Whether the act were Constitutional or not, it was always my opinion that it did not secure him (Stanton) from removal. I was, however, aware that there were doubts as to the construction of the law, and from the first I deemed it desirable that at the earliest possible moment, those doubts should be settled and the true construction of the act fixed by decision of the Supreme Court of the United States. My order of suspension in August last was in-

${ }^{15}$ According to Sherman's testimony in the impeachment trial, Impeachment I, 483, it was an ad interim appointment that the President proposed. But Sherman's Memoirs, 2d edition, II, 426, have the following: "To effect this removal, two modes were indicated by the President, to wit: to simply cause him (Stanton) to quit the War Office building, and notify the Treasury Department and the army staff departments no longer to respect him as Secretary of War; or to remove him and submit my name to the Senate for confirmation." This would imply that Johnson proposed to rid himself of Stanton, by nominating Sherman in the regular way to be Secretary of War. 
tended to place the case in such a position as would make a resortto a judicial decision both necessary and proper. My understanding and wishes, however, under that order of suspension were frustrated, and the late order for Mr. Stanton's removal was a further step toward the accomplishment of that purpose." ${ }^{16}$ The President also communicated the nomination of Thomas Ewing to be Secretary of War, though the notice did not actually reach the Senate until February 24, the 22d being Saturday and a holiday. The nomination was never acted upon. This step was cited in the impeachment trial, together with the notification of the removal, to show that the President had not sought to debar the Senate from exercising its concurrent power in the transaction, and such was probably its purpose; since the President could not have expected the Senate would confirm the appointment, and there is no evidence that Ewing would have accepted it.

Of the articles of impeachment brought against the President in I868, as an outcome, we are concerned only with the first three. ${ }^{17}$ Article I related exclusively to the removal of Stanton as a violation of the Tenure-of-Office Act. Reviewing the transaction in detail, from the suspension to the removal, it declared that the President, unmindful of his oath of office and of the requirement of the Constitution that the laws be faithfully executed, issued the order of removal with intent to violate the act regulating the tenure of certain civil offices, and was thereby guilty of a high misdemeanor in office. Articles II and III were concerned with the $a d$ interim appointment of Thomas. Article II declared that, contrary to the provisions of the Tenure-of-Office Act, and without the advice and consent of the Senate, that body being at the time in session, and without authority of law, the President issued to Lorenzo Thomas a letter of authority designating him to act as Secretary of War ad interim, and thereby committed a high misdemeanor. Article III differed from II only in its technical aspect; it declared that the President committed a

${ }^{16}$ Richardson, Messages and Papers of the Presidents, VI, 622-627.

${ }^{17}$ Although Article I was not voted upon, it is incorporated with other charges in Article XI, which with II and III forms the group upon which the Senate took action. 
high misdemeanor in office, in that he, without authority of law, during the session of the Senate, appointed Lorenzo Thomas to be Secretary of War ad interim, without the advice and consent of the Senate, no vacancy having happened in said office during the recess of the Senate, and no vacancy existing at the time when said appointment was made.

The charges against the President, then, so far as related to the War Department, are reducible to two (I) the removal in defiance of the Tenure-of-office Act, and (2) the failure to make a regular appointment. While the real animus lay in the combination of the two events into one transaction, whereby the concurrent power of the Senate had been evaded, the judges were required to distinguish between the two, and to apply to the case both the Tenure-of-office Act and the laws relating to the ad interim Cabinet service. The President, on the other hand, in his message to the Senate, February 22, I868, had made the two points. (I) That he desired to have the constitutionality of the Tenure-of-Office Act passed upon by the courts, and (2) That an Act of I795, which made it lawful for the President to designate any person at his discretion to supply a vacancy, for a period not to exceed six months, was still in force, so far forth as vacancies caused by removal were concerned. ${ }^{18}$ The President's counsel went into an exhaustive discussion of all the statutes relating to the ad interim service in the Departments. They maintained both that the Act of I795 had contemplated vacancies arising from death, resignation, appointment to other office, expiration of term, and removal, and that so far as the last three of these contingencies were concerned, it was not repealed by an Act of 1863 . The vacancy laws were discussed also by those Senators who entered opinions; and Sherman and Howe, who could not hold the President guilty for the removal of Stanton, having denied at the time when the Tenure-of-Office Act was passed, that the Cabinet proviso applied to the appointees of Lincoln, nevertheless found ground for conviction in that the designation of an ad interim Secretary was illegal, and was an attempt to usurp the War Office. On the other hand, Trumbull, who had made the ad interim appointment, and not the ${ }^{18}$ Richardson, Messages and Papers of the Presidents, VI, 622. 
removal, his ground for supporting the Senate resolution of censure, February 2I, now justified the President, on the ground that he had discovered that the Act of 1795 contemplated an area that was not covered by the Act of 1863 , and was so far still in force. Inasmuch as the acquittal was determined by the separation of seven of the forty-two Republican Senators who united with the twelve Democrats to make a vote of nineteen against thirty-five, and the adding of a single vote to the large majority would have raised it to the two thirds necessary to convict, Trumbull's change of ground was of signal importance.

However, the interest which these technicalities have for a study of vacancies in the Departments, should not obscure the fact that such hair-splittings really covered a luke-warmness towards the prosecution, and that the acquittal turned on more serious considerations than the defense reveals. An understanding was presumably reached between the President's counsel and a group of Senators, who, though opposed to Johnson, dreaded the effect of conviction upon the stability of the Government, that a Secretary of War, acceptable to all factions, would be nominated. Certain it is, that on April 24, I868, the name of General John M. Schofield of Illinois was sent to the Senate, by arrangement made between President Johnson and Schofield two or three days earlier through William M. Evarts. ${ }^{10}$ Not till May 26, was the President's acquittal recorded: and on the same day, Stanton communicated to the President his relinquishment of the War Office, on the ground that the resolution of the Senate censuring the removal and the ad interim designation had not been sustained by the issue of the trial. Two days later, May 28 , the Senate confirmed Schofield, first resolving that the War Department had been vacated by Stanton's resignation of two days previous. Judge Stanbery was also nominated to resume the office of Attorney-General; but the Senate refused to confirm him. The post was then tendered to Judge B. R. Curtis, who had been one of the President's counsel, but was declined. It was then urged upon Evarts, who was constrained by the sense of duty to accept it.

On May 25, the day before the articles of impeachment came to

${ }^{10}$ Schofield, Forty-Six Years in the Army, 413, 418. 
a vote, Senator Benjamin F. Wade, who as President pro tempore of the Senate would assume the office of President of the United States, in case Johnson were convicted, began to contrive a Cabinet, and consulted General Grant, who was the presumptive candidate of the Republican party for the next presidential term, as to what appointments would be agreeable. This kind of consultation was perhaps suitable to the novelty of the situation. It would seem to imply that Wade did not trust his own ability to compose the distracted Government during the ten months which were to ensue, and like Johnson, when he undertook to test the Tenure-of-Office Act, sought the cooperation of Grant as the most popular man of the hour.

President Johnson, on the other hand, had the grim satisfaction of recommending to Congress, shortly after his acquittal, a new rule for the presidential succession, in the event of the disability of both President and Vice-President. In a message of July 18, 1868, he stated that recent events had shown the necessity of an amendment to the Constitution for that purpose, since enactment by the Legislature might be of doubtful constitutionality and liable to repeal. ${ }^{20}$ Under an Act of I792, the succession was in the President pro tempore of the Senate, and failing him the Speaker of the House of Representatives. Johnson suggested that it was more suitable to vest it in the Executive branch of the Government than in either the Legislature or the Judiciary, especially since both the President pro tempore of the Senate and the Chief Justice of the Supreme Court might be members of a tribunal by which the vacancy in the Presidency was produced. He accordingly recommended an amendment to the Constitution whereby the duties of the President should, in the event contemplated, devolve upon some one of the Heads of the Executive Departments. Johnson's recommendation was scornfully ignored; but eighteen years afterwards, January I9, I886, Congress passed an act vesting in the Cabinet the succession to the Presidency, in case of the removal, death or other disability of both President and Vice-President, and making the order of precedence as follows: the Secretary of State, the Secretary of the Treasury, the Secretary

${ }^{20}$ Richardson, Messages and Papers of the Presidents, VI, 639. 
of War, the Attorney-General, the Postmaster-General, the Secretary of the Navy, and the Secretary of the Interior. ${ }^{21}$

As an immediate result of the trial proceedings, the entire law code relating to ad interim service in the Departments was revised. An act of July 23, 1868, swept away all of the preceding legislation upon the subject and ordered that the first or sole assis.tant in any Department should in case of the death, resignation, absence, or sickness of the head thereof, perform the duties of such head until a successor were appointed or the disability should cease. The President might, however, at his discretion authorize the head of another Department or some other officer therein who was appointed by the President with the advice and consent of the Senate, to perform the duties, provided that in case of death or resignation, the vacancy should not be supplied in this manner longer than ten days.

In actual practice the Assistant Secretaries had already become the usual, if not the regular directors of their departments, in case of the disability of the heads; and since this enactment, the practice has become almost invariable. Under the existing Departmental organization, it would provoke jealousy, if the Head of one Department were temporarily placed over another, unless some special situation seemed to necessitate the arrangement. The most recent instance of the sort occurred upon the death of Secretary Hay, July, I905, when President Roosevelt informally designated Secretary Taft of the War Department to take charge of certain matters appertaining to the State Department.

Upon the accession of President Grant, Congress acknowledged the temporary character of the Tenure-of-Office Act by so amending it, April 5, 1869, that the suspending power became almost equivalent to removal. The Cabinet proviso was stricken out; and in lieu of the provision that officers duly appointed and qualified should hold their places until successors should be appointed and qualified, the amendment declared that such officers should hold "during the term" for which they should have been appointed, unless sooner removed, etc.

An immediate result was a new precedent governing the retention

${ }^{21}$ George F. Hoar, Autobiography of Seventy Years, II, I68-17I. 
of Cabinet officers from one presidential term of four years into another. March 17, 1873, President Grant, with the concurrence of the Senate, reappointed all of his Cabinet, except the Secretary of the Treasury who was retiring, although their respective periods of service varied from four years and twelve days, in the case of the Postmaster-General, to one year and two months in that of the Attorney-General. The situation did not recur until rgor when President McKinley, on March 3, reappointed all of his Cabinet. March 6, 1905, President Roosevelt, entering upon a new term of office, likewise reappointed all of his Cabinet, except the two members who were retiring. This new practice does not extend to the interruption of a presidential term by the death of the President and the accession of another incumbent. Thus President Arthur retained permanently one member of the Cabinet whom he found in office, and the others remained a few months, but he reappointed none. President Roosevelt likewise made no reappointments until the expiration of the Constitutional term of his predecessor. 
President.

ULYSSES S. GRANT, Illinois.

Vice-President.

SCHUYLER COLFAX, Indiana.

March 4, I869, to March 4, I873.

SeCretary of State.

Elihu B. Washburne, of Illinois, March 5, I869.

Hamilton Fish, of New York, March II, I869.

Secretary of the Treasury.

John F. Hartley, of Maine (Assistant Secretary), ad interim, March 5, I869.

George S. Boutwell, of Massachusetts, March II, I869.

Secretary of War.

John M. SchofieLd, of Illinois; continued from last Administration.

JoHn A. Rawlins, of Illinois, March II, I869.

William T. Sherman, of Ohio, September 9, I869.

William W. Beiknap, of Iowa, October 25, 1869.

\section{AtToRney-General.}

J. Hubley Ashrón, of Pennsylvania (Assistant Attorney-General), acting, March 5, 1869.

EBenezer R. HoAR, of Massachusetts, March 5, I869.

Amos T. Akerman, of Georgia, June 23, I87o.

George H. Williams, of Oregon, December I4, I871, to take effect January Io, 1872.

Postmaster-General.

St. John B. L. Skinner, of New York (First Assistant Postmaster-General), ad interim, March 4, 1869.

John A. J. Cresswell, of Maryland, March 5, 1869.

SeCretary of the Navy.

William Faxon, of Connecticut (Assistant Secretary), ad interim, March 4, I869.

Adolph E. Borie, of Pennsylvania, March 5, I869.

George M. Robeson, of New Jersey, June 25, I869.

SECRETARY OF The INTERIOR.

JACOB D. Cox, of Ohio, March 5, 1869.

Columbus Delano, of Ohio, November I, 1870. 


\section{President.}

ULYSSES S. GRANT, Illinois.

Vice-President.

HENRY WILSON, Massachusetts. (Died November 22, 1875.)

President Pro Tempore of the Sediate.

THOMAS W. FERRY, Michigan. -

March 4, 1873, to March 4, 1877.

Secretary of State.

Hamilton Fish, of New York; continued from last Administration. HAMilton Fish, of New York; recommissioned March 17, 1873.

Secretary of the Treasury.

GeORGe S. Boutwell, of Massachusetts; continued from last Administration. William A. Richardson, of Massachusetts, March 17, 1873.

Benjamin H. Bristow, of Kentucky, June 2, 1874.

Charles F. Conant, of New Hampshire (Assistant Secretary), ad interim, June 21,1876

Lot M. MoRrill, of Maine, June 21, 1876.

\section{SECRETARY OF WAR.}

William W. Belknap, of Iowa; continued from last Administration.

William W. BeLknap, of Iowa; recommissioned March 17, 1873.

GEORGE M. RoBeson, of New Jersey (Secretary of the Navy), ad interim, March 2, 1876 .

Alphonso TAFT, of Ohio, March 8, 1876.

James D. Cameron, of Pennsylvania, May 22, 1876.

\section{AtTORNEY-GENERAL.}

Grorge H. Williams, of Oregon; continued from last Administration.

George H. Williams, of Oregon; recommissioned March 17, I873.

Edwards Pierrepont, of New York, April 26, 1875, to take effect May 15 1875 .

Alphonso Taft, of Ohio, May 22, 1876.

\section{Postmaster-General.}

JoHn A. J. Cresswell, of Maryland; continued from last Administration. JoHN A. J. CRESSWELL, of Maryland, recommissioned March 17, 1873.

James W. Marshall, of Virginia, July 3, 1874 .

Marshall Jewell, of Connecticut, August 24, 1874.

JAmes M. Tyner, of Indiana, July 12, 1876.

\section{Secretary of the Navy.}

GEORGe M. Robeson, of New Jersey; continued from last Administration.

GEORGE M. RoBEson, of New Jersey; recommissioned March 17, I873.

SECRETARY OF THE INTERIOR.

Columbus Delano, of Ohio; continued from last Administration.

Columbus Delano, of Ohio, recommissioned March $17,1873$.

Benjamin R. Cowen, of Ohio (Assistant Secretary), ad interim, September 30, 1875 .

ZACh ARIAH CHANDLER, of Michigan, October I9, 1875. 


\section{GRANT.}

Down to I869 the materials for the study of the Cabinet are rich and accessible. From the published correspondence and diaries of men in immediate touch with affairs, together with available manuscripts, we catch the inner spirit of Executive relations and incidents. But from I869 to I9I I, there is only the periodical literature, which is rarely a faithful picture of what it represents, and the memoirs and biographies that have been published too early to lift the veil from the personal features of political history. Only a bald outline of Cabinet events can be drawn. And yet the narrow glimpse that is afforded shows unmistakably that a fuller view would discover points of the liveliest interest and of much significance.

President Grant's administration is the unsavory period in Cabinet affairs. And it further presents a most extraordinary array of departures from the normal course of the Executive. It was variously styled a "military rule," a "personal rule," and a "departmental regime." The Executive Office was open to the "Senatorial group" that figured in the public prints at the time. And the ante-rooms were under the direction of members of General Grant's late military staff, who became a sort of "Kitchen Cabinet." It was as though George Mason's prediction had come to pass, that the President would become the tool of the Senate, or would be controlled by minions and favorites. ${ }^{1}$ Furthermore, the official Cabinet became both the camp of the President's personal friends and the battleground of politicians. Its roster was in a continual flux.

General Grant's naiveté about civil affairs resulted in the announcement of a most impracticable Cabinet slate. And, before a working Executive was fully secured, more than three months had elapsed. March 5, 1869, six Cabinet appointments were made, to be followed on the inth by a revisionary list of three.

${ }^{1}$ Chapter, The Origin of the Cabinet. 
There had been a special arrangement at the War Office that was in no way chargeable to inexperience. General Schofield was retained a week from the Johnson Cabinet, for the purpose of putting into operation certain new regulations concerning the War Department and the army, in which he and President Grant had been interested together, while the latter was General-in-Chief. ${ }^{2}$ The common interpretation of the matter was that a special compliment was paid to Schofield, because his assumption of the War Office had assisted in restoring peace between the Executive and Congress. At the expiration of a week, General John A. Rawlins was set over the Department. Both military comrade and personal friend of the President's, some men saw in him qualities that promised a very salutary influence over his chief.

In appointing a Secretary of the Treasury, President and Senators alike were convicted of ignorance or inadvertency. The man chosen was Alexander T. Stewart, the leading merchant of New York City. In this matter, General Grant manifested the disposition, often laid to his charge, to heap official honors upon men of wealth who had been of service to him. But Mr. Stewart by his peculiar talents was fitted for the office, and was ambitious to crown his success in the business world with public distinction. But a legal obstacle existed. And it was nothing less than the exclusion of men engaged in trade on a scale that made them importers from the higher offices in the Treasury Department, provided in the very Act that established the Department, and repeated in half a dozen

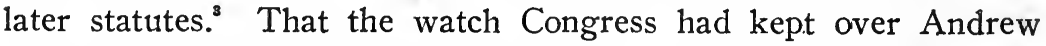
Johnson's Cabinet operations did not save the Senate from being caught napping the moment he was out of the Presidency was a bit ludicrous. But the Stewart appointment was confirmed without questions. When the blunder was discovered, the President was disposed to demand legislation that should remove the difficulty. And a motion was introduced by Senator Sherman to repeal the prohibiting clauses. Mr. Stewart, on the other hand, was considering the conveyance of his business interests to others during

${ }^{2}$ Schofield, Forty-Six Years in the Army, 418.

${ }^{3}$ Statutes at Large, I, 65. 
his incumbency. But the legal advices, in which the prospective Attorney-General, Judge E. Rockwood Hoar, took part, were unfavorable to special arrangements in any form. ${ }^{4}$ The issue was that the Treasury portfolio, was conferred upon George S. Boutwell, a man who had had the training that the great financial committees give, and had gained another sort of fame as a manager for the impeachment of President Johnson. The appointment was approved for bringing into the administration the element of Congressional experience. But the double representation that Massachusetts received by the choice of both Mr. Boutwell and Judge Hoar was a factor in the Attorney-General's early retirement.

The fruitless appointment at the Treasury seems to have been the loose cog that upset the gearing for the State Department. Elihu B. Washburne was incumbent of that portfolio for a single week, and then gave way to Hamilton Fish of New York. The selection of Mr. Washburne had something of the personal in it. As member of the House of Representatives for the Galena District of Illinois, he was one of the discoverers of General Grant. His assignment to the State Department was peculiar, because the nick-name he had earned in Congress, "watch-dog of the Treasury," seemed to mark him for the Finances. However, he immediately accepted the French Mission, and rendered very acceptable service during the Franco-Prussian War. Had he continued in the Cabinet after the appointment of General Rawlins, the anomaly of double representation must have extended to Illinois. But it would not have been so serious as the assignment of both the State and Treasury Departments to the Empire State.

Probably the Washburne appointment was not considered temporary, when it was made. The permanent incumbent had had no previous notice; but was pressed into the State Department in summary fashion. ${ }^{\circ}$ Though Mr. Fish had been a member of both Houses

${ }^{4}$ Senate Journal, 4I Congress, First Session, I4, 15, 28; Boutwell, Sixty Years of Public Affairs, II, 205; Hoar, Autobiography of Seventy Years, I, 24I.

${ }^{5}$ Boutwell, Sixty Years of Public Affairs, II, 2 I3.

- Pierce, Memoir of Charles Sumner, II, 39, Fish to Sumner, March 13, 1869. 
of Congress, and Governor of his State, his political retirement from the time of the formation of the Republican party made him a somewhat antiquated figure. There was not much enthusiasm over his appearance as Secretary of State; but the fact did not prejudice the recognition that he gained for presiding with dignity over diplomatic affairs, and negotiating the Treaty of Washington.

The Cabinet cast, as completed on March II, was broken again in June by the resignation of Secretary Adolph E. Borie from the Navy Department. The gentleman's qualifications for the office had consisted of his social position as a wealthy Philadelphian, and the favors he had shown to General Grant. Only one Senator, it is said, recognized the name, when the nomination was read. Naval affairs proving distasteful, Mr. Borie resigned, after an incumbency of less than four months, during which interval, as he himself pleasantly averred, Admiral Porter had directed the Department.' George M. Robeson, a prominent New Jersey lawyer, became a more permanent Secretary of the Navy.

A change then occurred that was a real misfortune to President Grant. Only six months after his appointment to the War Department, General Rawlins died. And his place was taken by General W. W. Belknap of Iowa, who was also a military favorite. ${ }^{s}$ General Jacob D. Cox, himself Secretary of the Interior at the time, is responsible for the statement that, if this break in the administration had not occurred, the President would not have fallen under the sway of politicians and army minions in the way that he did. Rawlins had no particular genius for civil affairs; but he possessed some insight into government by deliberation. This was what General Grant

${ }^{7}$ McCulloch, Men and Measures of half a Century, 350.

${ }^{8}$ For a brief interval, William T. Sherman, General-in-Chief of the Army, served as Secretary of War by a vacation commission, the office of AssistantSecretary having been abolished.

A somewhat similar expedient appears on the Cabinet rolls in the bridging over of the interval between the retirement of Postmaster-General Cresswell, July 3, 1874, and the appointment of Marshall Jewell. James W. Marshall, First Assistant-Postmaster-General, was made Head of the Department by a vacation commission. 
notoriously lacked, and the favor with which he regarded his Secretary of War gave promise that the deficiency might be supplied.

It is generally acknowledged that President Grant used the methods of his military command in directing his civil subordinates. The most astounding departure from official precedent, as described by Secretary Cox, was the affront given to the entire Cabinet, and especially the Secretary of State, in the negotiation of the treaty to annex San Domingo to the United States. The President's agent was General O. F. Babcock, who, in the role of irregular private secretary, bore some such relation to him, as Major Lewis had done to Jackson. There had been occasional discussion of the subject of annexation among the members of the administration, incidentally to overtures from the San Domingan Government. And, although the President had not committed himself, a general impression had settled down that both Executive and Congress were opposed to the project. General Babcock, however, was despatched to San Domingo for the alleged purpose of reporting as an engineer upon the desirability of one of the harbors for a coaling station. Some weeks later, the Cabinet was electrified by the President's announcement that Babcock had returned, bringing a treaty for the annexation of San Domingo, and that the difficulty of his having acted without proper diplomatic powers could be easily remedied by securing the signature of the consular agent. Cabinet discussion went no further than Secretary Cox's question: "But Mr. President, has it been settled, then, that we want to annex San Domingo?" But the treaty was duly submitted to the Senate. Secretary Fish tendered his resignation in consequence of the slight; ${ }^{10}$ but some influence constrained him to remain at his post, presumably fear for the President's soundness as a party man.

The McGarrahan Claim affair was the occasion of another extraordinary assertion of the President's discretion. In this matter, the Department of the Interior was concerned with a demand for a patent to mining lands in California. President Grant herein set at naught the official opinion of Attorney-General Hoar, and enjoined Secre-

' Jacob D. Cox, How Judge Hoar Ceased to be Attorney-General, in Atlantic Monthly, LXXVI, I62-I73.

${ }^{10}$ Reminiscences of Carl Schurz, III, 323. 
tary Cox from carrying out the statute that related to the subject." Both officers were among the ablest members of the Administration, and the unconventional treatment accorded to them was a factor in their retirement, though not the immediate circumstance.

The chief cause of the generally unsettled condition of this Cabinet was the strife between the reign of party politics in the Departments and the rising demand for Civil Service Reform. An exceptional opportunity for the control of the appointive offices by Congressmen had been afforded by the degradation of the Executive power in the hands of President Johnson. And a coterie of singularly astute politicians in the Senate had made haste to improve it. The chief of the "Senatorial group" was Roscoe Conkling who was now assuming Seward's place as party leader in New York. Oliver $P$. Morton of Indiana was another of its members. And figures that had been a little longer on the scene were Chandler of Michigan and Cameron of Pennsylvania. The reform movement, on the other hand, expressed itself in unmistakable terms in the Liberal Republican defection in I872. President Grant oscillated between the two forces. And Cabinet officers were both made and unmade for their reform sentiments.

Of the original appointments, both Judge Hoar and General Cox chanced to be reformers. Furthermore, Judge Hoar soon found occasion to ignore the rule of "Senatorial courtesy" in making recommendations for filling the great judicial offices that were created by the Act that established the United States Circuit Court. The President supported his Attorney-General; but was not equal to protecting him afterwards. ${ }^{12}$ He nominated Judge Hoar to the Supreme Bench of the United States, but disaffected Senators defeated the appointment. A little later the Attorney-General yielded his place to Amos T. Akerman of Georgia. The latter gentleman had little to recommend him except the fact that he was a Southern Republican. There were indications that his appointment was the price paid to the "carpet bagger" Senators for their votes on the San Domingan treaty. ${ }^{13}$ The influence of the Senatorial politicians

${ }^{11}$ The Nation, XI, 324.

${ }^{12}$ Boutwell, Sixty Years of Public Affairs, II, 211.

${ }^{13} \mathrm{~J}$. D. Cox in the Atlantic Monthly, LXXVI, I63-173. 
with the President became well assured during this session. Mr. Conkling's ascendency dated from a struggle to confirm a collector of customs at New York that terminated in July, 1870. ${ }^{14}$ A second reformer disappeared from the Cabinet for coming into conflict with Senator Cameron. Secretary Cox protested against the levying of assessments upon clerks in his Department in the elections of 1870. President Grant failed to sustain him. And Columbus Delano, who had been a member of the House of Representatives and latterly Commissioner of Internal Revenue, became Secretary of the Interior. With this reform sentiments disappeared from the administration.

President Grant entered upon his second term of office without giving the Liberal Republican movement any immediate notice. With a single exception, he reappointed his entire Cabinet. Secretary Boutwell of the Treasury was able to satisfy his preference for legislative work by election to the seat in the Senate that was vacated when Henry Wilson became Vice-President. His successor was William A. Richardson, whose credentials consisted in the fact that he represented the State of Massachusetts, and was already on the ground as Assistant-Secretary. The "carpet-bagger" AttorneyGeneral had previously given place to George H. Williams, who brought the Pacific Coast into the administration.

A peculiarly low ebb in the character of the Cabinet is now reached. Not only had the standards of ability fallen, but charges of corruption were rife. The columns of such a journal as the Nation, which was especially sane and reliable at this time, show the Secretaries under almost constant fire. Changes occurred in rapid succession. In June, 1874 , Secretary Richardson was driven from the Treasury Department by the scandal of the Sanborn contracts. These were contracts for the collection of certain taxes and excises that had been illegally withheld from the Government, in executing which a man named Sanborn collected, at an enormous commission, funds that were within the proper province of the Internal Revenue Bureau. The investigation by a committee of the House of Representatives would have resulted in a resolution of lack of confidence in the Secretary of the Treasury, had not the President quieted the

${ }^{14}$ Conkling, Life and Letters of Roscoe Conkling, 326. 
affair by appointing Mr. Richardson to the Court of Claims, and promoting Benjamin F. Bristow of Kentucky, who was an avowed Civil Service Reformer to the Head of the Treasury. ${ }^{15}$ Almost simultaneously, Postmaster-General Cresswell retired. There was a tender of the vacant place to Representative Eugene Hale of Maine, that is of interest for its factional significance. For, while Mr. Hale had personal ties to some of the Grant chieftains, he was identified politically with the fortunes of James G. Blaine, who was Speaker of the House of Representatives, and one of the new figures on the Presidential horizon. Between Senator Conkling and Mr. Blaine relations of avowed hostility already existed. ${ }^{16}$ Any idea of cementing factions was thrust aside by Mr. Hale's declining the Post-Office and its vast patronage for the alleged reason of ill health. ${ }^{17}$ The place was filled by the appointment of Marshall Jewell of Connecticut, a choice that is classed as one of General Grant's reforming measures. Meanwhile Attorney-General Williams had incurred censure for his looseness in prosecuting evaders of the excise. This was probably the cause of the refusal of the Senate to act upon his name, when President Grant nominated him for Chief Justice of the United States in December, $1874{ }^{18}$ In the following May, Edwards Pierrepont of New York succeeded to the Attorney-Generalship; and somewhat improved the credit of the office. ${ }^{19}$ In October, 1875, Secretary Delano retired from the Interior Department, where he had been under constant fire from the reformers and independents who never forgave him for succeeding General Cox. While Mr. Delano was ably succeeded by Senator Chandler, the appointment of the latter marked the tightening of the grip of the politicians upon the administration, which had relaxed during the preceding year, as a result of the disclosure of frauds in the internal revenue service.

The most serious scandal within the Executive grew out of Secretary Belknap's sale of traderships at the army posts; and was the

\footnotetext{
${ }^{15}$ Hoar, Autobiography of Seventy Years, I, 325.

${ }^{18}$ Boutwell, Sixty Years of Public Affairs, II, 260.

${ }^{17}$ The Nation, XIX, I.

${ }^{18}$ The Nation, XVII, 415.

${ }^{10}$ Ibid., XX, 305.
} 
occasion of the first and only impeachment of a Cabinet officer. This occurred in the spring of 1876 . On March 3, the House of Representatives adopted articles of impeachment, appointed managers, and notified the Senate; but while this action was being taken, the Secretary of War resigned, and the President accepted his resignation. The issue was now made, whether the Senate had authority to convict a party who had been an officer of the Government, but had ceased to be such, before impeachment proceedings were instituted. Upon the plea of lack of jurisdiction, the majority requisite to convict upon impeachment failed to be secured, though the vote stood 37 to 25 against the accused. ${ }^{20}$

The late Senator Hoar, who was the chief manager of the impeachment, expressed the belief that party feeling operated to save Belknap from the full penalty prescribed by the Constitution; and that the opinion expressed by the vote of the majority, that his liability was not terminated by resignation, will prevail hereafter, unless political sympathies should prevent. ${ }^{21}$ But, nevertheless, the way was found to vitiate the Constitutional provision for dealing with misconduct in office, so far as officers holding at the President's pleasure are concerned.

With the retirement of General Belknap, the War Office was momentarily conferred upon Judge Alphonso Taft of Ohio, who was, however, transferred to the Attorney-Generalship two months later, when Mr. Pierrepont, his predecessor in that office, became Minister to England. Though the change was approved by the better judgment of the country, its alleged purpose was to vacate the War Department for Don J. Cameron, Senator Cameron's son. ${ }^{23}$ The approach of the presidential election gave the remnant of the administration entirely to the politicians. Mr. Bristow, the reforming Secretary of the Treasury; had been for some time treading dangerous ground in the prosecution of the "whiskey ring" for the evasion of the excise wherein he had come into conflict with some of the President's personal favorites, notably General Babcock, the negotiator of

\footnotetext{
${ }^{20}$ Congressional Record, IV, Part 7, 'Trial of W. W. Belknap.

${ }^{21}$ Hoar, Autobiography of Seventy Years, I, 365.

${ }^{22}$ The Nation, XXII, 327.
} 
the San Domingo treaty. ${ }^{23}$ Postmaster-General Jewell, likewise, showed a disposition to scrutinize postal contracts more sharply than the prevailing sentiment required. ${ }^{24}$ Furthermore, the Republican National Convention, which incorporated a civil service reform plank in its platform, brought forward each of those gentlemen as a reform candidate for the presidential nomination. Mr. Jewell's following amounted to nothing more than the vote of his own State. But Mr. Bristow's candidacy was formidable enough to bring him into reproach for setting himself up against Senator Conkling, the administration candidate. ${ }^{25}$ Notwithstanding the warnings of the independent press that it would be unwise to open the campaign by offending the reforming Republicans, Mr. Bristow yielded his place in the Cabinet to Senator Lot M. Morrill of Maine; which was at least a more dignified arrangement than the one that simultaneously occurred in the Post-Office. In the latter Department, the promotion of James M. Tyner of Indiana from the position of Second Assistant was a bald expedient for securing a pivotal State to the Republican party, being presumably dictated by Senator Morton, who had rivalled Conkling in the administration councils, and had been himself a candidate for the presidential nomination.

An important change in the Executive organization occurred under President Grant. An act was passed, June 22, I870, to establish a Department of Justice whereof the Attorney-General became the head. The Attorney-Generalship as established by the original Judiciary Act, in addition to the function of prosecuting in the Supreme Court suits in which the United States was concerned, was charged with the duty of furnishing advice and opinions on questions of law to the President and the Heads of Departments, in matters concerning the performance of their duties. Washington viewed the office as a purely judicial one, but soon associated its incumbent with his Executive coadjutors in his Cabinet. Whether the officer should also advise Congress, or its Committees, as to the validity of pending legislation was a question that came up from

\footnotetext{
${ }^{23}$ The Nation, XXIII, 2.

${ }^{24}$ The Nation, XXIII, 18.

${ }^{25}$ The Nation, XXIII, III.
} 
time to time ; and Attorneys-General Wirt, Taney, Crittenden, Bates, Evarts, and Williams may be mentioned as having declined on legal grounds to render such service, although other incumbents of the office acted in this capacity by courtesy. By act of August 2, I86I, and incidentally to the general enlargement of the Departments to meet the demands of the Civil War, the Attorney-General was charged with the superintendence and direction of the marshals and district attorneys throughout the United States and its Territories. By the act which erected the office into the headship of a Department, the duties of the Attorney-General were left substantially as they had been previously defined, with the extension of his functions in the courts to correspond with the enlargement of the Federal judiciary. A Solicitor-General also was provided to assist the Attorney-General and to act in his stead in case of vacancy. or disability; and the two Assistant Attorney-Generalships already existing were continued; later acts have added additional assistants. The first Attorney-General to enjoy the dignity of being a Department Head was Amos T. Akerman of Georgia."

${ }^{26}$ The Government of the Confederate States anticipated the National Government in making the Attorney-General the Head of a Department, inasmuch as it passed an act, February 2I, 1861, to create a Department of Justice, wherein the powers of the Attorney-General were defined precisely as in the laws of the United States, after the supervision over marshals and district attorneys had been added. 
President.

RUTHERFORD B. HAYES, Ohio.

VICE-PRESIDENT.

WILLIAM A. WHEELER, New York.

March 5, I877, to March 4, I88I.

Secretary of State.

Hamilton Fish, of New York; continued from last Administration.

William M. Evarts, of New York, March I2, I877.

Secretary of the Treasury.

Lot M. MorriLl, of Maine; continued from last Administration.

John Sherman, of Ohio, March 8, 1877.

Henry F. French, of Massachusetts (Assistant Secretary), ad interim, March 4, I88I.

SECRETARY OF WAR.

James D. Cameron, of Pennsylvania; continued from last Administration.

George W. McCrary, of Iowa, March I2, 1877.

Alexander Ramsey, of Minnesota, December 10, 1879.

ATTORNEY-GENERAL.

Charles Devans, of Massachusetts, March 12, I877.

Postmaster-General.

James M. Tyner, of Indiana; continued from last Administration.

David M. Key, of Tennessee, March I2, I877.

Horace Maynard, of Tennessee, June 2, I88o.

SeCretary of the Navy.

George M. Robeson, of New Jersey; continued from last Administration. RIChard W. Thompson, of Indiana, March 12, 1877.

Alexander Ramsey, of Minnesota (Secretary of War), ad interim, December 2I, 1880 .

Nathan GoFf, JR., of West Virginia, January 6, I88I.

SECRETARY OF THE INTERIOR.

Zachariah Chandler, of Michigan; continued from last Administration. Carl Schurz, of Missouri, March I2, I877. 



\section{HAYES.}

The salient facts about the Hayes Cabinet are its draught upon the Independents, or Reformers, and its failure to represent the great factions of the Republican party. The combination that nominated Rutherford B. Hayes for the Presidency was an incongruous one. The very chieftains who controlled President Grant united with men who had been Liberal Republicans in 1872 , in a common purpose to defeat Mr. Blaine. But with the nomination determined, the disappointed candidates went through the forms of pledging their sincere support to the successful one. ${ }^{1}$ And the precarious issue of the election is probably to be attributed to the discredit which the Grant administration had incurred, and the success with which the Democrat party assayed the role of reform, rather than to defection among the Republican leaders. It would not be surprising, however, if there were a chapter of inside history, of a somewhat sensational character, regarding the pre-inaugural relations between the party standard bearer and the party chieftains. Senator Conkling was prevented by illness from taking the part in the campaign that had been arranged. What passed between him and Mr. Hayes on the subject of the New York patronage has not been revealed; but the recommendation of Thomas C. Platt of that State to be Postmaster-General is enough to incite conjecture. ${ }^{2}$ It was a forewarning that the party organization in New. York was to be at variance with the National administration, when Conkling refused to endorse the decision of the Electoral Commission. Blaine's defection seems also to have had its immediate cause in failure to dictate a Cabinet appointment; though the Senator from Maine had other grievances. The one exception to the estrangement between Hayes and the factions is found in his rela-

${ }^{1}$ Foulke, Life of Oliver P. Morton, I, 402.

${ }^{2}$ Conkling, Life and Letters of Roscoe Conkling, 520.

${ }^{8}$ Boutwell, Sixty Years of Public Affairs, II, 264. 
tions with Morton, who was a valued adviser during the campaign and in the formation of the Cabinet.

The support of the Republican candidate by the Independents was determined by Carl Schurz, lately a Senator from Missouri, and the acknowledged leader of the civil service reform movement. Hayes was disposed to recognize the demands of this movement, and it was under Mr. Schurz's advice that certain steps in that direction were taken. These included the civil service reform paragraph in the letter of acceptance, and the refusal to become a candidate for a second term of office, an observance of a rule advocated in the platform of the Liberal Republicans, four years before, and believed by them to be necessary to purging the Departments of political abuses. Mr. Schurz was invited to make suggestions about the Cabinet; and proposed William M. Evarts to be Secretary of State, and Benjamin F. Bristow, lately of the Grant administration, to be Secretary of the Treasury. Mr. Evarts, who had been Attorney-General under Johnson, after defending him on his impeachment, was now an Independent, and inclined towards civil service reform as strongly as any prominent man in New York, though he was less ardent than Schurz. Bristow's attitude towards reform had been fully demonstrated by his career in the Grant Cabinet, and the support which he commanded in the Republican National Convention. The President, however, had marked Mr. Schurz himself for the Cabinet, and had made his own choice for the Treasury, in the person of Senator John Sherman of Ohio. On the score of ability and previous training, Mr. Sherman was a highly eligible candidate, being chairman of the Senate Committee of Finance, while the important monetary questions of the Grant administration were under consideration; but he was not a reformer. Mr. Schurz was given a choice of the Post-Office and Interior Departments and took the latter. These three important appointments were definitely arranged late in February, when the Electoral Commission began to give signs that its findings would be in favor of the Republican party."

Besides departing from the rule of factional representation, this

"Sherman, Recollections of Forty Years in the House, Senate, and Cabinet, I, 56I-563. The Reminiscences of Carl Schurz, III, 373-375. 
Cabinet affords the anomaly of going outside of the party for one of its members. The suggestion that the Southern member should be taken from the ranks of the Democrats seems to have emanated from Mr. Schurz; and it was cordially taken up by the Presidentelect as an earnest of his determination to withdraw the remnants of military rule from the South. It was even proposed to put General Joseph E. Johnson at the head of the War Department; but conference with military men showed that such arrangement would very seriously embarrass the relations between the department and the army. Accordingly the project dwindled to making David M. Key of Tennessee Postmaster-General. Mr. Key had served in the army of the Confederacy as Lieutenant-Colonel; and since 1875, he had been a member of the United States Senate on the Democrat side. The opposition which must have been aroused by putting the patronage of the Post-Office into the hands of a Southern Democrat was forestalled, in a measure, by an arrangement to put James M. Tyner, whom political considerations had marked for head of the Department during the presidential campaign, into the first assistantship. The Morton influence was probably present in this; though that Senator's biographer asserts that Key himself requested the arrangement. Morton at least was given the control of the Cabinet appointment from Indiana, with a suggestion that he should accept it himself. He, however, preferred to remain in the Senate; and merely submitted a list of acceptable names from which Richard W. Thompson was chosen and ultimately assigned to the Navy.

The other Western appointment was that of George W. McCrary of Iowa, who was a prominent member of the House of Representatives, and had attracted special attention by introducing the resolution which led to instituting the Electoral Commission. Considerable interest attaches to the determination of Mr. McCrary's portfolio. His ambition for a judicial career connected his name with the Department of Justice; but a moral disqualification existed in his attitude towards the McGarrahan Claim, which was still unsettled. A solution was proposed in a temporary exchange of portfolios between Mr. McCrary and the member from New England. That

${ }^{\circ}$ Foulke, Life of Oliver P. Morton, II, 479, 480. 
this person should be General Charles Devens, Judge of the Supreme Court of Massachusetts, had been determined by advising with Senator George F. Hoar. This would have made Mr. Devens provisional Attorney-General and Mr. McCrary provisional Secretary of War; but Judge Devens, though willing to accept either office permanently, refused to enter into a temporary arrangement, upon the ground that the transfer would lead to surmises that his judicial services had not been satisfactory. Accordingly, Mr. McCrary was constrained to accept the War Department, while Mr. Devens became Head of the Department of Justice. ${ }^{6}$

The selection of Judge Devens as the representative of New England disaffected Senator Blaine, whose plans contemplated the placing of William P. Frye of Maine, in the Cabinet. To this President Hayes would not agree, though he made an offer to Mr. Hale, who had three years before received an overture from President Grant. $^{7}$ There is a curious letter from Mr. Blaine, written soon after the inauguration, in which he denies the current charges of opposition to the new Cabinet; and says that the President offered a place to Mr. Hale, but assigned as a reason for not taking $\mathrm{Mr}$. Frye the fact that he did not know him. ${ }^{8} \quad$ A very large number of actual Cabinet officers would have been excluded by the application of this rule.

The communication of the Cabinet list to the Senate aroused that body to a very extraordinary assertion of its powers of obstruction. Herein lay the means of redress against the President's independent course, and the scanty consideration which it accorded to the Senatorial chiefs. The present practice of referring Cabinet appointments to Committees was not established at this time, at least so far as incoming administrations were concerned; and, had it been so, the rule of courtesy which ordinarily exempts the Senate's own members from such reference, would have been applicable to two of these particular nominations. Accordingly very special significance attaches to the steps taken in confirming this Cabinet. On March 7,

${ }^{\circ}$ Hoar, Autobiography of Seventy Years, II, ro.

${ }^{7}$ Hoar, Autobiography of Seventy Years, II, 7.

${ }^{8}$ Gail Hamilton, Biography of James G. Blaine, 429. 
the nominations being delayed until that date, Senator Morrill of Vermont introduced a motion that each of the nominations, those of Sherman and Key included, be referred to the committee corresponding to the department in question, when appointed; and the motion promptly passed.

The next day, the clause relating to Sherman was judiciously reconsidered, and his appointment was confirmed, receiving 37 votes in its favor to II against. Two days after the original motion, it was announced that the committees were appointed, and that the Cabinet nominations were duly referred. One day more sufficed for the committees to report favorably, and the votes showed practically no opposition, Schurz, who was chief of the Independents, being confirmed with a single dissenting voice, while Evarts and Key, the one an Independent and the other a Democrat, each received two "nays." 8 The explanation of this change of attitude was that public opinion had interposed. During the three anxious days, mails and telegraph poured inquiries and expressions of disapproval into the Capitol, until it became evident that the country would not support the action of the Senate.

Although the Hayes Cabinet was an exceptionally able one, it was greatly hampered by the political disagreement between the Executive and Congress. In the House of Representatives, the Democrats had had a majority since the middle of Grant's second term of office; and the Republicans did not recover it until the election of 1880 . In the Senate, the coming of a Democrat majority, by the mid-term elections, was not more serious than the estrangement between the President and the factions. Mr. Blaine was out of sympathy with President Hayes's Southern policy; and was not pleased at the spectacle of Mr. Schurz in the Cabinet. ${ }^{10}$ During the last three years of the administration he did not enter the White House. Between Mr. Conkling and the administration there was a memorable war over the removal of the three leading United States officials at the port of New York; when the substitution of Edwin A. Merritt for Chester A. Arthur, as Collector of Customs, was accomplished by a vacation sus-

'Senate Executive Journal, 1877-1879, 3, 5, 6.

${ }^{10}$ Blaine, Twenty Years of Congress, II, 595-597. 
pension under the Tenure-of-Office Acts of 1867 and I869, the diffcult task of securing the assent of the Senate, being achieved largely through the strenuous efforts of Secretary Sherman. ${ }^{11}$ The death of Senator Morton shortly after the inauguration, put an end to support from that quarter.

The great task of resuming specie payments gave the Treasury Department the place of greatest prominence. Moreover, Secretary Sherman's political seniority over his chief had called forth the prediction that he would be the controlling spirit of the administration. But the issue proved that President Hayes maintained his authcrity over all his subordinates. On one occasion, in fact, he overruled his principal secretary within his own department. As he stated in an interview which he granted some years after his presidency, he had on at least two occasions decided and carried out matters against the wishes of the Head of the Department affected, one of them being Mr. Sherman whose opinion he usually valued. ${ }^{12}$ The difference referred to was probably with reference to the veto of the Bland-Allison Bill for the remonetization of silver, passed in I878. Sherman himself says of this matter that he had been in communication with Senator Allison as to desirable amendments upon the bill; and believed that a way had been found to prevent the dreaded evils; therefore he did not sustain the President in his veto, though he did not care to antagonize his decision. ${ }^{13}$ President Hayes and Secretary Sherman also differed on the important question of retiring United States notes. The Annual Message of I880, and the Report of the Secretary of the Treasury, transmitted to Congress on the same day, make radically different suggestions upon this subject, this being one of the few cases which raise the question whether the President has the same authority over the reports from the Treasury as he has over those from the other Departments. ${ }^{14}$

The recognition of civil service reform in the Cabinet did not go far enough to have very great results. Mr. Schurz would have had

${ }^{11}$ Burton, John Sherman, 290-296.

${ }^{12}$ Stevens, Sources of the Constitution of the United States, 167, Footnote.

${ }^{13}$ Sherman, Recollections of Forty Years, II, 623.

${ }^{14}$ Richardson, Messages, VII, 616; Sherman, Recollections, II, 794. 
the Treasury, Interior, and Post-Office Departments all filled by men who were thorough reformers; but the Interior, over which he himself presided, was the only one where a consistent effort in that direction was made. He remarked, some years later that experience had convinced him that no President, however firm and courageous he might be, could succeed in systematic reform, if he had to carry on the reform against his own Cabinet. Inasmuch as Hayes had declined a second term of office, Sherman became an active aspirant for the Presidency; and did not escape the charge of using the vast patronage of the Treasury to secure the nomination in 1880 . In the Post-Office, Key was understood to have reforming inclinations; but they were of little account with Tyner dispensing the Northern patronage. The division of authority in this Department worked badly; and probably had something to do with entailing the Star Route scandals upon the next administration.

The recognition of the political South amounted to nothing more than sentiment; and when Mr. Key retired in June, I880, to accept a District Judgeship, the idea was abandoned. Horace Maynard, who succeeded him, was also from Tennessee; but had previously been in the Republican ranks, having held a diplomatic office under President Grant.

Two other Departments changed hands. Secretary McCrary found satisfaction for his judicial aspirations in a Circuit Judgeship, and was succeeded in the War Office by Alexander Ramsay of Minnesota. Secretary Thompson, whose naiveté in matters pertaining to naval armaments had afforded some amusement among his associates, retired, as the administration was nearing its end, to become Chairman of the Panama Canal Commission. President Hayes offered to appoint in advance the man whom President-elect Garfield had selected for the Navy; but inasmuch as the incoming Cabinet was not yet determined upon, he designated Nathan Goff of West Virginia for the remnant of his term.

Notwithstanding the political isolation of the Hayes administration, it was doubtless due in part to the creditable manner in which it acquitted itself that the Republican party in I880, with General James A. Garfield for its presidential candidate, polled a larger popular vote than it had done for six years. 
President.

JAMES A. GARFIELD, Ohio. (Died September 19, I881.)

VICE-PRESIDENT.

CHESTER A. ARTHUR, New York.

March 4, I88I, to September I9, I88I.

SeCretary of State.

William M. Evarts, of New York; continued from last Administration.

James G. Blaine, of Maine, March 5, I88I.

Secretary of the Treasury.

Henry F. French, of Massachusetts (Assistant Secretary), ad interim, March 4, I88I.

William Windom, of Minnesota, March 5, I88I.

\section{SeCretary OF War.}

AleXANDer RAmSey, of Minnesota; continued from last Administration.

ROBERT T. Lincoln, of Illinois, March 5, I88I.

\section{Attorney-General.}

Charles Devens, of Massachusetts; continued from last Administration.

Wayne MacVeagh, of Pennsylvania, March 5, I88I.

Samuel F. Phillips, of North Carolina (Solicitor-General), ad interim, March 7, I88r.

$$
\text { Postmaster-General. }
$$

Horace Maynard, of Tennessee; continued from last Administration.

Thomas L. James, of New York, March 5, I88I.

Secretary of the Navy.

Nathan GofF, JR, of West Virginia; continued from last Administration. William H. Hunt, of Louisiana, March 5, I88I.

SECRETARY OF THE INTERIOR.

Carl Schurz, of Missouri; continued from last Administration. Samued J. KrRkwood, of Iowa, March 5, I88r. 


\section{GARFIELD.}

Notwithstanding the fact that the Republicans secured the House of Representatives, with a good prospect of controlling the Senate, by the elections of 1880 , the factional situation rendered the problem of forming an administration that could command the support of Congress one of almost unparalleled difficulty. The lines along which President Garfield proceeded were determined, to a great extent, by the circumstances which brought about his nomination. In I880 the hostility between Conkling and Blaine continued to divide the Republican party. However, Mr. Conkling, instead of confronting Mr. Blaine in the Republican Convention as a personal candidate for presidential honors, overmatched him with a strong combination that supported ex-President Grant for a third term of office, the balance of power being held by the supporters of " favorite sons," of whom the strongest was Sherman. After long and tedious balloting, the Blaine forces combined with the lesser delegations upon General James A. Garfield of Ohio, who had had a distinguished career in the House of Representatives, and was now Senator-elect. The Grant or Conkling forces stood firm throughout, showing on the last ballot 306 votes. It was a political necessity that the VicePresidential candidate should represent that wing of the party; and Chester A. Arthur, who had been prominent in New York politics as Collector of Customs at New York City and Chairman of the Republican State Committee, was nominated for the second place on the ticket.

The problem of dealing with the " 306 ," when the time came to form the Cabinet, was complicated by its geographical distribution, which seriously crossed State lines. Even New York had not stood solidly for General Grant; for the Republican party was distinctly divided there into the "Regulars" or "Stalwarts," whom Conkling commanded, and a much smaller wing of "Independents." Furthermore a like division existed in the States of Pennsylvania and Illi- 
nois, the Grant forces being commanded in the one by Don Cameron, who had succeeded to his father's place in Keystone politics, and in the other by General John A. Logan. It was this division in the State delegations to the Republican National Convention that caused the memorable controversy over the "unit rule"; in which Garfield, who was himself delegate-at-large from Ohio, scored a triumph over Conkling, and Judge William H. Robertson of New York came forward as leader of the Independent Republicans in Conkling's own State.

The moment that the Republican triumph was assured, the President-elect, in his home at Mentor, began to feel the pressure of throngs of Cabinet makers, both through the mails and by personal visitation. The story of the making of no other Cabinet is so dramatic. And it would seem that a certain cheapening of Cabinet office in the popular mind, which had resulted from the low condition of that body under President Grant, asserted itself afresh, as the Independent regime of President Hayes came to an end." In the midst of these solicitations, Mr. Garfield wrote to a friend: "Pressure for the appointment of anybody to the Cabinet has come to be, in my mind, an almost insuperable obstacle in that direction." 2 Still the most suitable of the names proposed were duly considered, and several found temporary places upon the Cabinet slate. The plan that Mr. Garfield adopted had two parts ; first, to give the highest consideration to that wing of the party which had nominated him, and from which he might expect a consistent support; second, to accord to the Grant wing, men who were moderate "Regulars," but were not the creatures of the respective "Stalwart" leaders. Stated in geographical terms, the plan accorded a member to New England, New York, Pennsylvania, and Illinois respectively, with two of the remaining portfolios reserved for the West and Northwest, and one for the

${ }^{1}$ The only first hand material on the subject that has been published is the correspondence between Garfield and Blaine, which appears in Gail Hamilton's Biography of the latter. However, two or three of Garfield's confidential friends within his Congressional District are reliable authority for additional facts.

${ }^{2}$ Garfield to B. A. Hinsdale, January II, I88I. 
South. ${ }^{3}$ Late in November, 1880 , the President-elect, while on a visit to Washington, offered the State portfolio to Mr. Blaine, which was formally accepted about three weeks later. The next selection, that of Mr. Wayne MacVeagh of Pennsylvania for the Attorney-Generalship, was hardly less significant, for Mr. MacVeagh, being an Independent and a Hayes Republican, was as far from supporting Blaine as he was from supporting Conkling; and notwithstanding his political heresy, he was "persona grata" to the Pennsylvania "Regulars," by virtue of being Simon Cameron's son-in-law. A fortunate arrangement was also made for the representation of Illinois, in that Robert T. Lincoln, son of the martyred President, became Secretary of War. Politically, Mr. Lincoln had followed the lead of General Logan in supporting Grant, but sentiment made his appointment acceptable to all factions.

The New York "Stalwarts," under Mr. Conkling's lead, were not so easily satisfied; and forced an issue with the President-elect about the filling of the Treasury Department, which it is hard to interpret in any other light than as a special precaution for the control of the great offices at the port of New York for which they had unsuccessfully contended with President Hayes. The newspapers have recently published a distorted account of the attempt to make Levi P. Morton Secretary of the Treasury. ${ }^{.}$It is known, however, in Mr. Garfield's former constituency, that there was such an attempt, and that it began before the election, and was not relinquished until the very hour of the inauguration. Mr. Garfield considered Mr. Morton ineligible to the Treasury for his business connections; but would have assigned him a different portfolio, had that gentleman's prompters allowed him to accept it; as is was, he made Morton Minister to France.

Moreover, having resolved to place the Treasury portfolio outside of Wall Street, but not necessarily outside of New York, he favorably considered Charles J. Folger, Judge of the Supreme Court of that State, and a moderate "Regular"; which arrangement failed for

'Gail Hamilton, Biography of James G. Blaine, 490; Blaine to Garfield, December 10, 1880 .

'December, 1907. 
the reason that Judge Folger was at the time personally interested in a claim against the United States. At one time it occurred to Mr. Garfield to appoint Senator Conkling himself to the Treasury Department. But there was reason to fear that the discord which must have resulted would defy all the conciliating forces that could be brought to bear; and it can hardly be said that the proposition was discussed for any other than its psychological interest." The ultimate arrangement for the representation of the Empire State, was the appointment of Thomas L. James to be Postmaster-General. Mr. James was a "Stalwart," having held under the Conkling regime the office of Postmaster of New York City, in which he had shown administrative ability of a high order.

Additional difficulties attended the filling of the Treasury. The efficient administration of Mr. Sherman, during the "resumption" period, raised the question of his retention; but such an arrangement would have entailed political embarrassments, and discrimination among the members of the retiring Cabinet seemed undesirable. Moreover, Mr. Sherman himself preferred to return to the Senate. There was, furthermore, a feeling that the agricultural, rather than the manufacturing or commercial part of the country, should on this occasion furnish the Minister of Finance. And considerations of locality, combined with those of fitness, pointed to William B. Allison, Senator from Iowa, and William Windom, Senator from Minnesota, both of whom had been prominent members of Congressional committees corresponding to the Treasury Department. " Inasmuch as it was thought that Mr. Allison would be the more willing of the two to leave the Senate, the first offer was made to him. But the result proved the contrary. Furthermore, Mr. Allison was prevented by domestic considerations from undertaking the social responsibilities of a Cabinet officer. Accordingly, Mr. Windom became Secretary of the Treasury.

The selection of a suitable representative of the South was also a difficult matter, because of the lack of representative Republicans

'Gail Hamilton, Biography of James G. Blaine, 497.

- Sherman, Recollections of Forty Years, II, 802.

' Gail Hamilton, Biography of James G. Blaine, 495. 
in that section of the country. Late in January, Mr. Garfield jocosely wrote to his prospective Secretary of State: "The Southern member still eludes me, as Creusa's image eluded Aeneas. One by one, the Southern roses fade. Do you know of a magnolia blossom that will stand our Northern climate?" The problem was finally solved by appointing William H. Hunt of Louisiana, to be Secretary of the Navy. A Secretary of the Interior was found in Senator Samuel J. Kirkwood of Iowa. That the incoming Cabinet was less able than the retiring one was generally admitted; but it was received on the whole with expressions of approval.

It was one of those Cabinets in which the Secretary of State was conspicuously superior to all of his colleagues by virtue of ability and previous experience. There was a preconceived opinion, moreover, which might be paralleled with the cases of Lincoln and Seward, and Hayes and Sherman, that the Secretary would be President $d e$ facto. In fact there is an impression, fastened upon the reading public by the Nation, which has taken its inspiration entirely from "Stalwart" sources, that such was actually the case. Moreover, the Blaine publications carry a similar impression, though from a different motive. ${ }^{8} \quad$ The late Senator Hoar is perhaps the only prominent man who has distinctly asserted that President Garfield would have shown himself master of his own administration, had the public had time to find him out; but he is also the only one free from prejudices, and in possession of inside information, who has written upon the subject. $^{\circ}$

Mr. Blaine had had the longer and more varied public experience. Moreover, when his supporters turned to Garfield, he at once espoused the cause of the new leader with an eagerness that went rather more than half way in making him a confidential adviser during the months that preceded the election and the inauguration. ${ }^{10}$ Mr. Garfield, however, by no means lacked knowledge of public men, and was fully aware of Mr. Blaine's weaknesses. In 1876, he had

${ }^{8}$ Stanwood, James G. Blaine, 238.

${ }^{\circ}$ Hoar, Autobiography of Seventy Years, I, 399, 400.

${ }^{10}$ Gail Hamilton, Biography of James G. Blaine, 500; Blaine to Garfield, January 28; February 5, I88I. 
preferred him for the presidency before Conkling and Morton, but after Bristow." Moreover, he had written of Blaine only two years before his own elevation to the Presidency: "Though I have long been warmly his friend, I have not been blind to his faults, which it seems to me, are growing rather than decreasing. He seems to have undoubted faith in management, while I have but little, and I think his mind is warped by the constant pressure of the presidential idea upon him." ${ }^{12}$

In considering Mr. Blaine's influence over Mr. Garfield's administration, it should be noticed that Mr. Garfield had surrounded himself with a "coalition" Cabinet, in fact one that was as truly such as Lincoln's, though by no means composed of such great personalities. The presence of two Grant men at the council table assured the existence of an anti-Blaine element; furthermore, the Secretary of State had promptly found a strong counterpoise in the AttorneyGeneral..$^{13}$ And it is known that in one important appointment Garfield supported MacVeagh over Blaine. A Cabinet of this type could hardly have been dominated by any of its members, and have held together.

The most striking of President Garfield's acts which has been ascribed to Secretarial influence was the change in the office of collector at the port of New York, whereby William H. Robertson, a leader of the Independents, superseded Edwin A. Merritt, whom President Hayes had appointed in the face of Senatorial opposition. The contemporary "Stalwart" version of this matter, as stated by General Grant, was that this was the continuation of an attempt to ruin Senator Conkling, that had been begun by President Hayes; and that it would not have occurred, if Mr. Blaine had not been in the Cabinet." A recent "Stalwart" writer, however, takes the ground that the appointment was not Mr. Blaine's act at all, but an impulsive turn on President Garfield's part, that he took because a list of appointments made a day or two before, and more acceptable

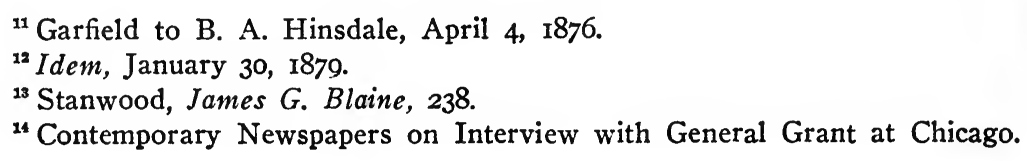


to Mr. Conkling, had called forth criticism from a different quarter. ${ }^{25}$ The two versions are equally in error. Mr. Garfield had decided, not impulsively but after long deliberation, to give conspicuous recognition to the New York Independents, and he had singled out Mr. Robertson for his stand against the " unit rule." 16 One of his advisers in the matter had been Judge Folger, who approved the appointment. That Mr. Garfield had always regarded the prevalent dictation of National appointments by Senators with disfavor, was proven by his previous career. The appointment was not Mr. Blaine's. He had been invited into the administration, under the express declaration by $\mathrm{Mr}$. Garfield that it was not to be made any man's battle-ground for the next. And the only way in which he could have shared in the Robertson appointment, was in exerting an influence as to the time when the nomination was made. ${ }^{17}$ The fact that PostmasterGeneral James did not go with the two New York Senators in resigning, although he had joined with them and Vice-President Arthur in a protest against the appointment, ${ }^{18}$ bespeaks Mr. Garfield's influence.

President Garfield's long illness, extending from July 2 to September 19, I88I, threw the Executive into a situation that there was no precedent for dealing with. The question was raised, whether it was not an occasion for the Vice-President to assume the direction of the Government. Moreover, the President, who was much of the time apprized of the course of public affairs, was fully competent to delegate extraordinary functions to his Secretary of State, had he desired to do so; which arrangement would have been better in keeping with the trend of Executive development than a resort to the more Constitutional expedient. There was abundant willingness on Mr. Blaine's part; but other members of the Cabinet were unwilling. A few precedents might have been unearthed out of Washington's administration for the Cabinet to deliberate without the President's attendance. The actual course of events was a Government by

\footnotetext{
${ }^{25}$ Boutwell, Sixty Years of Public Affairs, II, 273, 274.

${ }^{16}$ Garfield to B. A. Hinsdale, April I4, I881.

${ }^{17}$ Mrs. James G. Blaine, Letters, I, I97, March 24, I88I.

${ }^{18}$ Conkling, Life and Letters of Roscoe Conkling, 640.
} 
Departments, each head of necessity assuming an extraordinary. discretion. The fact that Congress was not in session, made this arrangement the more satisfactory. The collegiate Cabinet was practically suspended, unless it were for ceremonial purposes. In that character and no other, did the Secretary of State hold the precedence. 
President.

CHESTER A. ARTHUR, New York.

President Pro Tempore of the Senate.

THOMAS F. BAYARD, Delaware.

DAVID DAVIS, Illinois.

GEORGE F. EDMONDS, Vermont.

September 20, I88I, to March 4, I885.

Secretary of State.

James G. Blaine, of Maine; continued from Garfield's Administration.

FrEDERICK T. FreLINGHUYSEN, of New Jersey, December I2, I88I.

Secretary of the Treasury.

William Windom, of Minnesota; continued from Garfield's Administration.

Charles J. Folger, of New York, October 27, I88I.

Charles E. Coon, of New York (Assistant Secretary), ad interim, September 4,1884 .

Henry F. FRENCH, of Massachusetts (Assistant Secretary), ad interim, September 8, 1884 .

Charles E. Coon, of New York (Assistant Secretary), ad interim, September I5, 1884 .

Walter Q. GResham, of Indiana, September 24, I 884

Hugh MCCulloch, of Indiana, October 28, I884.

HENRY F. FRENCH, of Massachusetts (Assistant Secretary), ad interim, October 29, I884.

SeCretary of War.

ROBERT T. LINCOLN, of Illinois; continued from Garfield's Administration.

Attorney-General.

Wayne MacVeagh, of Pennsylvania; continued from Garfield's Administration.

Samuel F. Phillips, of North Carolina (Solicitor-General), ad interim, November I2, I88I.

Benjamin H. Brewster, of Pennsylvania, December I9, I88I.

Postmaster-General.

Thomas L. JAmES, of New York; continued from Garfield's Administration.

Thomas L. James, of New York, recommissioned October 27, I88I.

Tімотну O. Howe, of Wisconsin, December 20, I88I.

Frank Hatton, of Iowa (First Assistant Postmaster-General), ad interim, March 26, 1883.

Walter Q. Gresham, of Indiana, April 3, I883.

Frank Hatton, of Iowa (First Assistant Postmaster-General), ad interim, September 25, I884.

Frank Hatton, of Iowa, October I4, I884.

\section{Secretary of the Navy.}

William H. Hun'r, of Louisiana; continued from Garfield's Administration. William E. Chandler, of New Hampshire, April I2, I882.

SECRETARY OF THE INTERIOR.

SamUel J. KiRkwood, of Iowa; continued from Garfield's Administration. Henry M. Teller, of Colorado, April 6, I882. 


\section{ARTHUR.}

President Arthur's course in establishing his administration is somewhat of an enigma; though perhaps the political situation at President Garfield's death affords a sufficient clew to its solution. The doctrine of a personal right on the President's part to select his own advisers, which had been rather strengthened than otherwise by the events attendant upon the impeachment of Johnson, afforded sufficient ground for the country to expect a change of Cabinet. But the hostility between the party factions, which had now changed places, was a yet stronger reason. The newspapers represented the new President as being constantly surrounded by the "Stalwart" chiefs; and it was a common prediction that Conkling, now a private citizen, would receive a prominent appointment. On September 22, I88I, the Garfield Cabinet tendered their resignations ; and President Arthur accepted them to take effect some time after the next regular meeting of Congress. It was the middle of April, I882, however, before the changes were completed; and no entirely new slate was at any time presented, though the portfolios changed hands singly, until only Secretary Lincoln of the War Department remained. Towards the close of October, I88I, Secretary Windom, not waiting to transmit his Annual Report to Congress, as the President desired of the retiring officers, vacated the Treasury Department, hoping to return to the Senate. President Arthur first nominated as Mr. Windom's successor ex-Governor Edwin D. Morgan of New York. Rumors were rife, however, that the choice was only temporary and that the portfolio was being reserved for Conkling himself. Mr. Morgan belonged to the "Stalwart" wing of the party; but was a somewhat antiquated figure, having received his first offer of the Treasury from Lincoln at the time of Fessenden's retirement. Furthermore, his business connections were called in question, while his name was before the Senate. He was confirmed, however, but declined the office. Accordingly, Judge Charles J. Folger became 
Secretary of the Treasury, the disqualification which existed when President Garfield tendered that post to him, being now removed.

This appointment seems to mark a withdrawal on President Arthur's part from Conkling's influence. A few weeks later, February 2I, I882, he honored his former chief with the offer of an appointment to the Supreme Bench of the United States $;{ }^{1}$ but in making up his official household, he determined upon a middle course, so far as outward indications show. In November, Attorney-General MacVeagh retired; and was succeeded by Benjamin H. Brewster, who was, like his predecessor, a Pennsylvania lawyer. In December, Secretary Blaine was permitted to retire, and was succeeded by exSenator Frederick T. Frelinghuysen of New Jersey. Neither of these appointments had any particular bearing upon the factional situation. Postmaster-General James ${ }^{2}$ retired a few weeks after Mr. Blaine, and was succeeded by ex-Senator Timothy O. Howe of Wisconsin, who was a Grant man. Secretaries Kirkwood and Hunt retained their positions until the following April, when Senator Henry M. Teller of Colorado became Secretary of the Interior, and William E. Chandler of New Hampshire, Secretary of the Navy, the latter being a Blaine man. ${ }^{3}$

The Arthur Cabinet was one of only moderate ability; moreover, its personnel shifted much, though the changes were confined to the Treasury and Post-Office Departments. Postmaster-General Howe retired in April, I883; and was succeeded by Walter Q. Gresham of Indiana, who was not a great Cabinet officer, but was quite unique for the fact that after holding two portfolios in a Republican administration, he appeared at the head of a Democrat Cabinet. In September, 1884, Secretary Folger died in office; whereupon Mr. Gresham was transferred to the Treasury, and Frank Hatton of Iowa, previously First Assistant Postmaster-General became the Head of

${ }^{1}$ Conkling, Life and Letters of Roscoe Conkling, 676.

${ }^{2}$ Postmaster-General James had been recommissioned a little more than a month after President Arthur's accession pursuant to an Act of June, 1872, which limited the tenure of the Postmaster-General to the term of the President appointing him and 30 days thereafter.

${ }^{3}$ Autobiography of Thomas Collier Platt, 180. 
the Department. A month later, Mr. Gresham quitted the Cabinet to accept a Circuit Judgeship ; and Hugh McCulloch of Indiana, who had been Secretary of the Treasury under Lincoln and Johnson, was called to that office.

The probable explanation of Mr. Arthur's failure to set up a Conkling regime is found in the discrediting of the ex-Senator by the New York Legislature. Fortune was not likely to favor the "Stalwarts" at the next presidential election; and Mr. Arthur, like every other of the accidental Presidents, was a candidate for another term of office. On the other hand, any serious alliance with the Blaine faction was scarcely possible, although Mr. Blaine would probably have continued in the State Department, had it been desired. The apparent object of Mr. Arthur's course was to build up a third faction by drawing followers from the other two; but this he was not a sufficiently forceful man to accomplish. 


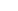


President.

GROVER CLEVELAND, New York.

ViCe-PRESIDENT.

THOMAS A. HENDRICKS, Indiana. (Died November 25, 1885.)

President Pro Tempore of the Senate.

JOHN SHERMAN, Ohio.

JOHN J. INGALLS, Kansas.

March 4, I885, to March 4, I889.

Secretary of State.

FREDERICK T. FRELINGHUYSEN, of New Jersey; continued from last Administration.

Thomas F. BAyard, of Delaware, March 6, I885.

Secretary of the Treasury.

Hugh MCCulloch, of Indiana; continued from last Administration.

Daniel Manning, of New York, March 6, I885.

Charles S. Fairchild, of New York, April i, I887.

SECRETARY OF War.

ROBERT T. LINCOLN, of Illinois; continued from last Administration.

Winliam C. EndicotT, of Massachusetts, March 6, I885.

Attorney-General.

Benjamin H. Brewster, of Pennsylvania; continued from last Administration. Augustus H. Garland, of Arkansas, March 6, I885.

Postmaster-General.

Frank Hatton, of Iowa; continued from last Administration.

WiLliam F. ViLAs, of Wisconsin, March 6, I885.

Don M. Dickinson, of Michigan, January I6, I888.

Secretary of the Navy.

William E. Chandler, of New Hampshire; continued from last Administration.

William C. Whitney, of New York, March 6, I885.

SECRETARY OF THE INTERIOR.

Lucius Q. C. Lamar, of Mississippi, March 6, r885.

HENRY L. MulDrow, of Mississippi (First Assistant Secretary), ad interim, January 10, 1888 .

William F. VILAS, of Wisconsin, January 16, 1888.

Sécretary of Agriculture.

Norman J. Coleman, of Missouri, February 13, 1889. 



\section{CLEVELAND.}

President Grover Cleveland introduced an important improvement into the methods of Cabinet making by persistently violating the rule against the double representation of a State. For, although his own Cabinets were not superior or even equal to some that had been formed under the strictest geographical rules, later Presidents have secured greater fitness in their Heads of Departments by the subordination of locality to other considerations. Furthermore, the return of the Democrat party to power restored to the Southern States the representation in the Executive councils which they had enjoyed before the breaking up of the Buchanan Administration on the eve of the Civil War. President Cleveland's Cabinet appointments were as follows: Senator Thomas F. Bayard of Delaware, Secretary of State; Daniel Manning of New York, Secretary of the Treasury; Judge William C. Endicott of Massachusetts, Secretary of War; Senator Augustus H. Garland of Arkansas, Attorney-General ; William F. Vilas of Wisconsin, Postmaster-General; William C. Whitney of New York, Secretary of the Navy; and, Senator Lucius Q. C. Lamar of Mississippi, Secretary of the Interior. Manning and Whitney, the two members from New York, both of whom were business men, were personal friends of Mr. Cleveland, and had had much to do with securing his nomination for the Presidency. Mr. Vilas was the recognized leader of the Democrat party within his State; and seems to have attracted Mr. Cleveland's attention by his part in the Democrat National Convention of 1884. On the whole political services received a more than ordinary recognition in forming the administration. However, the selection of three Senators, two of whom, Messrs. Bayard and Lamar, had been conspicuous among members of their party in Congress, was favorable to the desired intimacy between Executive and Legislature. It is a curious fact that the confirmation of the Cabinet was delayed a day, by an objection to Mr. Bayard on the part of a Democrat Senator from 
Virginia, who made the charge that the proposed Secretary of State had more sympathy with England than with the United States, and hence ought not to be entrusted with the foreign policy of the country. ${ }^{1}$

The Cabinet was enlarged during this administration by the creation of the Department of Agriculture. A minor office bearing that name had been established by act of May 15, 1862, under the direction of a Commissioner of Agriculture. The duties of this officer were to distribute useful information concerning agriculture; also to propagate and distribute new plants and seeds. A very general demand had arisen, however, among the farmers of the country for a more substantial organization, and in response to repeated resolutions from agricultural societies, Congress passed an act, February 9, I889, to "enlarge the powers and duties of the Department of Agriculture and to create an Executive Department to be known as the Department of Agriculture." A Secretary and an Assistant Secretary were provided for who should receive the same salaries as were paid to the Heads and Assistants in the other Executive Departments. The duties were continued as under the earlier office. The first incumbent of this Department was Norman J. Coleman of Missouri. It was not until McKinley's administration, when it received an eminently vigorous head, that it acquired sufficient im. portance to justify its creation.

Changes in the Cabinet personnel were caused by the retirement of Secretary Manning, because of ill health, and the appointment of Secretary Lamar to an Associate Judgeship in the Supreme Court of the United States. The vacancy in the Treasury Department was filled by the promotion of Charles S. Fairchild, of New York, whom Secretary Manning had chosen as First Assistant, and who had been the virtual head for some time. The Interior Department was filled by the transfer of Postmaster-General Vilas, to whose former place Don M. Dickinson of Michigan was appointed.

If the Executive relations of this administration differed conspicuously from the normal order, the fact has not been revealed. Perhaps Mr. Cleveland had less intercourse with members of Con-

${ }^{1}$ New York Times, March 6, 1885. 
gress than many Presidents because of his lack of previous connection with the National Government, and his independent stand. In the Executive he was doubtless the controlling force. It has been affirmed by one of the politician editors, who had the entrée to the White House, that President Cleveland's Cabinet officers were simply advisory as to the direction of their Departments and that every question of importance came to him for final decision. ${ }^{2}$

This administration affords a striking illustration of the fact that there is no power to unify the policies of Cabinet officers, under the American system, below the President. Incidentally to the negotiations with England, respecting the North-Eastern and Behring Sea fisheries, Mr. Manning, the Secretary of the Treasury, issued orders which were distinctly at variance with those of Mr. Bayard, the Secretary of State; whereupon President Cleveland asserted what policy should be enforced. ${ }^{3}$ On the whole, this Cabinet was not a brilliant one; but it seems to have been harmonious and loyal to its chief.

${ }^{2}$ A. K. McClure, Our Presidents and How We Make Them, 334.

${ }^{3}$ House Executive Documents, XX; Hart, Practical Essays, I29. 



\section{President. \\ BENJAMIN HARRISON, Indiana. \\ Vice-PRESIDENT. \\ LEVI P. MORTON, New York.}

March 4, I889, to March 4, I893.

Secretary of. State.

Thomas F. BAyard, of Delaware; continued from last Administration.

James G. Blaine, of Maine, March 5, I889.

William F. Wharton, of Massachusetts (Assistant Secretary), ad interim, June 5,1892 .

JoHN W. Foster, of Indiana, June 29, I892.

William F. Wharton, of Massachusetts (Assistant Secretary), ad interim, February 23, 1893.

\section{Secretary of the Treasury.}

Charles S. Fairchild, of New York; continued from last Administration. William Windom, of Minnesota, March 5, i889.

Allured B. Nettleton, of Minnesota (Assistant Secretary), ad interim, January 30, I89I.

Charles Foster, of Ohio, February 24, I89I.

SECRETARY OF WAR.

William C. EndicotT, of Massachusetts; continued from last Administration. Redfield Proctor, of Vermont, March 5, I889.

Lewis A. Grant, of Minnesota (Assistant Secretary), ad interim, December 6, 1891 .

Stephen B. Elkins, of West Virginia, December 22, I891.

\section{AtTORNEY-General.}

Augustus H. Garland, of Arkansas; continued from last Administration. William H. H. Miller, of Indiana, March 5, I889.

\section{Postmaster-General.}

Don M. Dickinson, of Michigan; continued from last Administration. John Wanamaker, of Pennsylvania, March 5, r889.

SeCretary of The Navy.

William C. Whitney, of New York; continued from last Administration. Benjamin F. Tracy, of New York, March 5, i889.

SECRETARY OF THE INTERIOR.

William F. VILAS, of Wisconsin; continued from last Administration. JoHN W. Noble, of Missouri, March 5, 1889.

SeCretary of Agriculture.

Norman J. Coleman, of Missouri; continued from last Administration. JEREMIAH M. RuSK, of Wisconsin, March 5, I889. 



\section{BENJAMIN HARRISON.}

President Benjamin Harrison repeated the Garfield Cabinet in the two most conspicuous Departments; which fact was probably due to the partial survival of the same conditions within the Republican party as had existed eight years before. Mr. Blaine, after being defeated by Mr. Cleveland in I884, had not seriously stood for the Presidential nomination in 1888 ; but neither had he ceased to be the dictator of the largest faction in the party. This fact added to his personal qualifications attracted President Harrison to him as the most eligible head for the State Department. Furthermore, it seemed expedient to award the Treasury portfolio to the West; and Mr. Windom was again the most obvious candidate after eliminating Sherman and Allison. Once more the New York appointment had an inside history that is not yet disclosed in its details. The socalled "promise" of the Treasury to Levi P. Morton in I88I was echoed in a claim that a like pledge was now given to Thomas C. Platt. The late Senator has declared that Mr. Harrison gave such a promise in writing, without producing the document, however. ${ }^{1}$ A very plausible interpretation of both "promises" is that the New York dictators told a North-Western President-elect what was expected of him, beyond his power to assert his independence on every occasion. At the last moment, Benjamin F. Tracy was permitted to accept the Navy, which Mr. Morton had been forbidden to do. The War Office was assigned to ex-Governor Redfield Proctor of Vermont, who had been a prominent supporter of General Harrison in the Republican National Convention; Mr. Proctor's associations with Senator Edmunds, moreover, marked him as an anti-Blaine man. A Secretary of the Interior was found in John W. Noble of Missouri, a lawyer, who was unknown outside of his State, and was probably recommended by considerations of locality, and his previous acquain-

${ }^{1}$ Thomas Collier Platt, Autobiography, 218. 
tance with President Harrison. The Department of Agriculture was assigned to ex-Governor Jeremiah Rusk of Wisconsin, who had been a member of the House of Representatives, and had acquired some reputation in his gubernatorial office. The appointment which aroused the most unfavorable comment was that of John Wanamaker, the great Philadelphia merchant, to be Postmaster-General; it being alleged that the cause of his receiving Cabinet honors, was his service in raising a campaign fund at a critical moment. Nevertheless, Mr. Wanamaker brought to his office great executive ability, while the filling of the Attorney-Generalship from purely personal considerations made a notably weak spot in the administration. President Harrison conferred this office upon William H. H. Miller of Indiana, his law partner and intimate friend. Later when he desired to appoint Mr. Miller to the Supreme Bench of the United States, he was prevented by the knowledge that he could not be confirmed.

This administration, like the one that preceded it, affords an important illustration of conflict between Departments, and reveals the powerlessness of the Secretary of State to enforce his policies upon his colleagues. In the controversy between the United States and Chili, in I89I-'92, either Mr. Blaine, Secretary of State, and Mr. Tracy, Secretary of the Navy, were at cross purposes, about the conduct of the United States naval officers who were charged with interference between factions in the Chilean Government, or the State Department acquiesced in an assumption of authority over foreign relations on the part of the Navy. ${ }^{2}$ There is, moreover, reason to suppose that President Harrison overbore Mr. Blaine in this matter, and virtually took it out of his hands, in issuing the ultimatum, which demanded a thorough apology from the Chilean Government."

The relations between Harrison and Blaine show with especial distinctness the authority which the President can exercise over his so-called "Premier," even when the advantages of ability, and previous position are on the Secretary's side; though Mr. Blaine's

${ }^{2}$ The Nation, LIV, 44, Navalism; Hart, Practical Essays, 129.

${ }^{3}$ The Nation, LIV, 64. 
biographers are so non-committal about the alleged causes of disagreement that little more than the general fact can be asserted. ${ }^{4} \mathrm{Mr}$. Blaine's superiority as an experienced statesman over his chief and colleagues was more marked than it had been in the Garfield administration; yet it is patent on the surface that he was not the dominating force of the administration. A serious personal affront was sustained at the outset by President Harrison's refusal to let him appoint his First Assistant Secretary, in which relation he had desired to have one of his sons associated with him, as Webster and Seward had done. The Chilean affair seems to indicate that he was at least once overruled in his foreign policy. It is true that his administration of foreign affairs was extraordinarily energetic, and his Pan-American policy led him to concern himself with the McKinley Tariff Act of I89o, to an extent that is unusual with a Cabinet officer. Nevertheless, his position was hampered both by domestic troubles and increasing alienation from his chief. The same sort of trouble existed in the latter quarter, as had come between Webster and Fillmore, and Lincoln and Chase. June 4, I892, Mr. Blaine resigned from the Department. He had abruptly quitted a Cabinet meeting shortly before, and the story arose that he was angry at the Secretary of the Treasury, though his biographer asserts that illness was the cause. ${ }^{5}$ Three days after his resignation, the Republican National Convention met, and nominated President Harrison on the first ballot for a second term of office, Mr. Blaine being the second candidate on the list, but showing only one-third as many votes as his former chief.

John W. Foster of Indiana, an eminent authority on International Law, succeeded Mr. Blaine as Secretary of State. Two other changes in the Cabinet personnel had already occurred. In January, I89I, Mr. Windom, Secretary of the Treasury, died in office, and was succeeded by ex-Governor Charles Foster of Ohio. In December of the same year, Mr. Proctor, Head of the War Department, resigned to take the seat in the Senate that was vacated by the death of Mr. Edmunds, and was succeeded in the Cabinet by Representative Stephen B. Elkins of West Virginia.

4 Stanwood, James G. Blaine, 334-336; Gail Hamilton, Biography of James G. Blaine, 704.

'Stanwood, James G. Blaine, 340. 


\section{President. \\ GROVER CLEVELAND, New York. \\ VICE-PRESIDENT. \\ ADLAI E. STEVENSON, Illinois.}

March 4, I893, to March 4, I897.

\section{Secretary of State.}

William F. Wharton, of Massachusetts (Assistant Secretary), ad interim; continued from last Administration.

JWALtER Q. Gresham, of Illinois, March 6, I893.

EDWin F. UHL, of Michigan (Assistant Secretary), ad interim, May 28, 1895. RICHARD OLNEY, of Massachusetts, June 8, I895.

Secretary of the Treasury.

Charles Foster, of Ohio; continued from last Administration.

JoHN G. Carlisle, of Kentucky, March 6, I893.

\section{SeCretary of War.}

Stephen B. Elkins, of West Virginia; continued from last Administration. Daniel S. Lamont, of New York, March 6, 1893.

\section{AtToRney-General.}

WiLliam H. H. MiLLER, of Indiana; continued from last Administration.

$\checkmark$ RICHARD OLNEY, of Massachusetts, March 6, I893.

Judson Harmon, of Ohio, June 8, I895.

\section{Postmaster-General.}

John Wanamaker, of Pennsylvania; continued from last Administration. Wilson S. BisselL, of New York, March 6, I893.

William L. Wilson, of West Virginia, March I, I895.

\section{Secretary of the Navy.}

Benjamin F. Tracy, of New York; continued from last Administration. Hilary A. Herbert, of Alabama, March 6, I893.

\section{SECRETARY OF THE INTERIOR.}

JoHN W. NoBlE, of Missouri; continued from last Administration.

HoKe SMITH, of Georgia, March 6, I893.

David R. Francis, of Missouri, September I, I896.

JoHn M. ReYnolds, of Pennsylvania (Assistant Secretary), ad interim, September 2, I8g6.

\section{Secretary of Agriculture.}

JEREMIAH M. RUSK, of Wisconsin; continued from last Administration. Julius Sterling Morton, of Nebraska, March 6, I893. 



\section{CLEVELAND.}

When President Cleveland was elected for a second term of office in 1892, having been defeated by the Republican candidate in 1888 , he recalled none of his former Cabinet; although Mr. Bayard, who had been his Secretary of State, now succeeded to the dignified post of Ambassador to England. In making up his second administration, Mr. Cleveland put the State Department into the hands of Judge Walter Q. Gresham, who had figured in the Arthur Cabinet as a moderate Grant man, and had shown a good deal of strength in the Republican National Convention of $\mathbf{1 8 8 4}$, as a candidate for the Presidency; but had latterly bolted his party out of dislike of the McKinley Tariff Act. The fact that Judge Gresham showed only average qualifications for administering the foreign affairs of the country, renders the selection the more peculiar. A Secretary of the Treasury was found in John G. Carlisle of Kentucky, formerly Speaker of the House of Representatives, and latterly a prominent member of the Senate. The South received two additional portfolios, in that Hilary A. Herbert of Alabama, formerly a member of the House of Representatives, where he had served on the Naval Committee, became Secretary of the Navy, while Hoke Smith of Georgia, who had not previously been connected with the National Government, became Secretary of the Interior. New England was recognized by the appointment of Richard Olney, an able Massachusetts lawyer, to the Attorney-Generalship. The Department of Agriculture was assigned to Julius Sterling Morton of Nebraska. New York, as before, furnished two members, and both of the appointments were personal, Daniel S. Lamont, private secretary of Mr. Cleveland's former administration, becoming Secretary of War, and Wilson S. Bissell, a former law partner, Postmaster-General.

No incidents of particular significance are associated with this Cabinet. The administration incurred a reputation for weakness, 
which neither accords with the firm character of the President, nor does justice to the ability of his advisers. This was due chiefly to the disagreement within the party over the Wilson Tariff Bill of I894, and the dissentions over the silver question. The member of the House of Representatives, who gave his name to the new tariff law, William L. Wilson of West Virginia, entered the Cabinet in 1895 as Postmaster-General. David R. Francis of Missouri, assumed the Interior portfolio late in the administration. The most conspicuous change, however, occurred in the State Department, to which Attorney-General Olney was transferred in June, I895, Secretary Gresham having died in office. The ensuing vacancy in the Department of Justice was filled by the appointment of Judson Harmon of Ohio. 
President.

WILLIAM McKINLEY, Ohio.

VICE-PRESIDENT.

GARRET A. HOBART, New Jersey. (Died November 21, 1899.)

President Pro Tempore of the Senate.

WILLIAM P. FRYE, Maine.

March 4, 1897, to March 4, I901.

\section{SECRETARY of State.}

RICHARD OlNEY, of Massachusetts; continued from last Administration. John Sherman, of Ohio, March 5, 1897.

William R. Day, of Ohio, April 26, I898.

Alvey A. Adee (Second Assistant Secretary), ad interim, September 17, I898. JoHn HaY, of the District of Columbia, September 20, 1898.

Secretary of the Treasury.

JoHN G. CARLISLE, of Kentucky; continued from last Administration. Lyman J. GaGe, of Illinois, March 5, 1897.

\section{SECRETARY OF WAR.}

Daniel S. Lamont, of New York; continued from last Administration. Russell A. Alger, of Michigan, March 5, 1897.

Elitu Roor, of New York, August I, I899.

\section{Attorney-General.}

JUDSON HARMON, of Ohio; continued from last Administration.

JoSEPH MCKenNA, of California, March 5, I897.

JoHN K. RICHARDS, of Ohio (Solicitor-General), ad interim, January 25, 1898. John W. Griggs, of New Jersey, January 25, I898.

\section{Postmaster-General.}

William L. Wilson, of West Virginia; continued from last Administration. JAmes A. Gary, of Maryland, March 5, I897.

Charles Emory Smith, of Pennsylvania, April 2I, I898.

Secretary of the Navy.

Hilary A. Herbert, of Alabama; continued from last Administration. JoHN D. LoNG, of Massachusetts, March 5, 1897.

SECRETARY OF THE INTERIOR.

David R. Francis, of Missouri; continued from last Administration. CoRnelius N. BLISS, of New York, March 5, I897.

Ethan A. Hitch Cock, of Missouri, December 2I, I898.

Secretary of Agriculture.

Julius Sterling MoRTon, of Nebraska; continued from last Administration. JAMES Wilson, of Iowa, March 5, 1897. 
President.

WILLIAM McKINLEY, Ohio. (Died September 14, I9or.)

Vice-PRESIDENT.

THEODORE ROOSEVELT, New York.

March 4, IgOI, to September I4, I90I.

\section{Secretary of State.}

JoHn Hay, of the District of Columbia; continued from last Administration. JoHn Hay, of the District of Columbia; recommissioned March 5, I90I.

Secretary of the Treasury.

Lyman J. GaGe, of Illinois; continued from last Administration.

Lyman J. Gage, of Illinois; recommissioned March 5, I90I.

SECRETARY OF WAR.

ElıHU Roor, of New York; continued from last Administration.

ELIHU RooT, of New York; recommissioned March 5, I9or.

Attorney-General.

JoHN W. GRIGGS, of New Jersey; continued from last Administration.

JoHn W. Griggs, of New Jersey; recommissioned March 5, I90I.

JoHN K. Richards, of Ohio (Solicitor-General), ad interim, April r, Igor.

Philander C. Knox, of Pennsylvania, April 5, rgor.

\section{Postmaster-General.}

Charles Emory Smith, of Pennsylvania; continued from last administration. Charles Emory Smith, recommissioned March 5, I90I.

\section{Secretary of the Navy.}

JoHN D. LoNG, of Massachusetts; continued from last Administration.

JoHN D. LoNG, of Massachusetts; recommissioned March 5, 1901.

SECRETARY OF THE INTERIOR.

Ethan A. Hitchсоск, of Missouri; continued from last Administration. Ethan A. Hitchсоск, of Missouri; recommissioned March 5, I9or.

Secretary of Agriculture.

JAmes Wilson, of Iowa; continued from last Administration. JAmes Wilson, of Iowa; recommissioned March 5, I90I. 


\section{MCKINLEY.}

In 1896 , the Republican party entered upon a new era, and elected William McKinley as President. Inasmuch as the great party issue was the maintaining of the gold standard, the selection of the Secretary of the Treasury was regarded as being, in a peculiar sense, an index to the administration policy. January 28, 1897, the Nation advocated the appointment of Lyman J. Gage of Illinois, who had never been in politics, but whose knowledge of monetary affairs was attested by his high standing with the American Association of Bankers. The qualifications urged were that Mr. Gage was a believer in the gold standard, that he was not an advocate of bimetalism, national or international, and that he approved of a banking system regulated by, but otherwise independent of the Government. Almost simultaneously, the selection of Mr. Gage for the Treasury portfolio was announced. Although some of the other Departments were very ably filled, considerations of merit were mixed with the gratification of local pride, and with purely political aims, in determining the appointments. The State Department was manipulated in a manner that has no exact parallel. It received a semi-honorary head in the person of John Sherman, who was too far advanced in years to assume the direction of the. office, and against his own judgment was withdrawn from the Senate, presumably for the purpose of vacating a seat for Mark A. Hanna, who had sprung into great political prominence as Chairman of the National Republican Committee. William R. Day, a neighbor and professional partner of the President's, was shortly made Assistant Secretary of State. The War Department was filled by General Russell A. Alger, ex-Governor of Michigan. The Navy Department was accorded to John D. Long of Massachusetts, formerly Governor of his State, and a member of the Lower House of Congress. The Assistant Secretary of the Navy was Theodore Roosevelt of New York, and the tradition that he brought about the appointment of Admiral, then Commodore, Dewey, to the 
command of the Asiatic Station, even though it be an overstatement, is not an exaggerated illustration of the part which officers of this rank have begun to take in their Departments. Cornelius N. Bliss of New York, became Secretary of the Interior; while the modern rule that the South must have one member in a Republican Cabinet received a half recognition in the appointment of James A. Gary of Maryland, to the Postmaster-Generalship. The Department of Agriculture was filled by James Wilson of Iowa, a practical farmer, and a professor of scientific agriculture. The State of California, hitherto never represented in the National Executive, received a complimentary recognition in the appointment of Joseph McKenna, Judge of the United States Circuit Court, to the Attorney-Generalship; the real purpose being apparently explained ten months later, when Mr. McKenna was appointed to the Supreme Court of the United States.

This Cabinet proved to have less than the average permanence; but as it changed, it increased its efficiency. The outbreak of the War with Spain in 1898 revealed its weak places. Secretary Sherman retired in April, and Assistant Secretary Day became the titular, as he had previously been the actual, head of the State Department. Postmaster-General Gary also avoided the additional stress which his Department must incur, by a timely resignation; and Charles Emory Smith, editor of the Philadelphia Press, succeeded him. More notable changes came with the close of the War. Secretary Day became one of the members of the Peace Commission which assembled at Paris in September, I898; and on his return, he was made Associate Justice of the Supreme Court. Meanwhile, the State Department received one of its most distinguished incumbents in John Hay, who had been introduced to public affairs as private secretary to Lincoln, and had enjoyed an extended diplomatic career.

While the Navy Department emerged from the hostilities with Spain with high credit, the War Office was discredited by friction with the head of the army. Though a study of this Department would discover many instances of difficulty along this line, it would find an aggravated case in the affair between Secretary Alger and General Miles. Charges of gross incompetency in the administration 
of the Department constrained President McKinley to order an investigation of certain bureaus; but he still retained the Secretary a full year in the face of much public criticism; he then requested his resignation through the agency of Vice-President Hobart, Mr. Alger's candidacy for a seat in the Senate serving to ease the situation. The Secretaryship of War was now likely to become the most important Cabinet office, inasmuch as that Department would direct, for a time, the governing of the new insular dependencies. President McKinley looked for a man of legal rather than military training to be the counsellor and agent of this new task, and in choosing Elihu Root of New York, secured an eminently vigorous Secretary of War, who promptly addressed himself not only to the new problems, but also to correcting the defects in the military organization which the war had discovered.

Secretary of the Interior Bliss, also from New York, had quietly retired from the Interior Department a year before, having presumably found it an uncongenial task to cope with abuses in the Land Office and Pension Bureau. He was succeeded by Ethan A. Hitchcock of Missouri, whose longer incumbency and more strenuous support were fruitful of important results.

When the Cabinet was reappointed at the beginning of President McKinley's second term of office, no changes were made in its personnel; but a month later Attorney-General Griggs retired, and was succeeded by Philander C. Knox of Pennsylvania, whose ability as a lawyer was.certified by the opposition to him on the ground that he had previously been employed by the steel trust and other large corporations.

When the assassination of President McKinley occurred in Buffalo, September 5, 1901, the members of his Cabinet, with only one or two exceptions, gathered together there, to assume the ceremonial functions which custom would devolve upon them in the event of the President's death. Secretary of State Hay was designated at this time by the press as the "senior member" and the "ranking member" of the Cabinet. Moreover, his place in the Presidential succession, under the law of 1886 , was recognized by his remaining at the seat of Government, while the new President, Theodore Roosevelt, accompanied the funeral party. 


\section{President.}

THEODORE ROOSEVELT, New York.

President Pro Tempore of the Senate.

WILLIAM P. FRYE, Maine.

September 14, I90I to March 4, 1905.

Secretary of State.

JoHn Hay, of the District of Columbia; continued from McKinley's Administration.

Secretary of the Treasury.

Lyman J. GAGE, of Illinois; continued from McKinley's Administration.

Leslie M. Shaw, of Iowa, January 9, 1902.

\section{SECRETARy OF War.}

Elihu Root, of New York; continued from McKinley's Administration. William H. TAFT, of Ohio, January II, I904.

\section{Attorney-General.}

Philander C. Knox, of Pennsylvania; continued from McKinley's Administration.

William H. Moopy, of Massachusetts, July I, Ig04.

Postmaster-General.

Charles Emory Smith, of Pennsylvania; continued from McKinley's Administration.

Henry C. Payne, of Wisconsin, January 9, 1902.

Robert J. Wynne, of Pennsylvania, October ro, r904.

SeCretary of the Navy.

JoHN D. Long, of Massachusetts; continued from McKinley's Administration. William H. Moody, of Massachusetts, April 29, 1902.

PaUl MorTon, of Illinois, July I, Ig04.

SeCRETARY OF THE INTERIOR.

Ethan A. Hrtchсоск, of Missouri; continued from McKinley's Administration.

Secretary of Agriculture.

JAmes Wilson, of Iowa; continued from McKinley's Administration.

Secretary of Commerce and Labor.

George B. Cortelyou, of New York, February i6, I903.

VICTOR H. MetCalF, of California, July I, I904. 
President.

THEODORE ROOSEVELT, New York.

VICE-PRESIDENT.

CHARLES W. FAIRBANKS, Indiana.

March 4, I905 to March 4, I909.

\section{Secretary of State.}

JoHN HAY, of the District of Columbia; recommissioned March 6, 1905.

Elinu Root, New York, July 7, 1905.

Robert Bacon, of New York, January 27, 1909.

Secretary of the Treasury.

Leslie M. Shaw, of Iowa; recommissioned March 6, 1905.

George B. Cortelyou, of Massachusetts, January 15, 1907, to take effect March 4, 1907 .

SeCretary of War.

William H. TAFT, of Ohio; recommissioned March 6, 1905.

Luke E. Wright, of Tennessee, June 29, 1908.

AtToRney-General.

William H. Moody, of Massachusetts; recommissioned March 6, I905.

Charles J. Bonaparte, of Maryland, December 12, 1906.

Postmaster-General.

George B. Cortelyou, of New York, March 6, 1905.

GEORGE vON L. MEYER, of Massachusetts, January I5, I907, to take effect March 4, 1907.

Secretary of the Navy.

Paul Morton, of Illinois; recommissioned March 6, 1905.

Chas. J. Bonaparte, of Maryland, July I, I905.

Victor H. MetCALf, of California, December I2, I906.

Truman H. NewberRy, of Michigan, December I, I908.

SeCRETARY OF THE INTERIOR.

Ethan A. Hitchcock, of Missouri; recommissioned March 6, 1905.

James R. Garfield, of Ohio, January 15, 1907, to take effect March 4, I907.

SECRETARY OF Agriculture.

James Wilson, of Iowa; recommissioned March 6, I905.

SECRETARY OF COMMERCE AND LABOR.

Victor H. Metcalf, of California; recommissioned March 6, 1905.

Oscar S. Straus, of New York, December I2, 1906. 


\section{ROOSEVELT.}

President Roosevelt forestalled the resignation of the McKinley Cabinet by requesting its members to continue in office, and announcing that he would not inaugurate a new administration, but complete that of his predecessor. Notwithstanding this determination, the Cabinet was in a state of fluctuation during his entire presidency, going through two seasons of recasting, prior to the expiration of his predecessor's Constitutional term, and being two or three times readjusted in the course of Mr. Roosevelt's second term of office.

A few weeks after the assembling of Congress in December, I90I, Postmaster-General Smith resigned to resume his duties as editor of the Philadelphia Press, and was succeeded by Henry C. Payne of Wisconsin, who had some political prominence as a member of the National Republican Committee. Simultaneously, Secretary Gage of the Treasury Department returned to private life; and ex-Governor Leslie M. Shaw of Iowa, an open candidate for the presidential nomination of 1904, was called into the Cabinet. A few months later, Secretary Long of the Navy Department retired to resume his profession; and William H. Moody, a member of the Massachusetts delegation in the House of Representatives, succeeded him in the Cabinet, a selection which satisfied the President's desire to keep a New England man in his administration, and was attributed by the press to the influence of his confidant Senator Lodge.

In February, 1903, a Cabinet appointment was necessitated by the establishment of an Executive Department of Commerce and Labor, which had been strongly urged by President Roosevelt in his Annual Message of December, I9or. The President's recommendation was to establish a Department of Commerce, a proposition which called out the endorsement of the merchants and manufacturers of the country. A bill for the purpose was promptly introduced in the 
Senate; and in the following session, February I4, I903, an Act was passed to establish a Department of Commerce and Labor. It was to be the province and duty of the Department to foster, promote, and develop the foreign and domestic commerce, the mining, manufacturing, shipping, and fishery industries, the labor interests, and the transportation facilities of the United States. Many bureaus and offices discharging the functions herein enumerated already existed; and the Department of Commerce and Labor, like that of the Interior, was built up to a great extent, by relieving the older Departments of branches which more appropriately belonged under a different organization and title. The arrangement was not satisfactory to the American Federation of Labor, which organization showed a disposition, both at the time and afterwards, to demand a separate Department to look after its interests. The first incumbent of the Department of Commerce and Labor was George B. Cortelyou of New York, who had been private secretary to President McKinley, and was retained in that capacity by Roosevelt.

Early in 1904, Secretary of War Root relinquished public office for a time; but the prominence which the Department had sustained under his administration suffered no falling off by the succession of Judge William H. Taft of Ohio, previously head of the Commission for governing the Philippine Islands. A few months later AttorneyGeneral Knox left the Cabinet, and assumed the seat in the Senate, which was vacated by the death of Matthew M. Quay of Pennsylvania. Secretary Moody was now transferred to the AttorneyGeneralship, and the resulting vacancy in the Navy was filled by the appointment of Paul Morton of Illinois. The latter choice provoked much criticism, partly because of Mr. Morton's Democratic antecedents, and partly on account of his relations with the business world. And the arrangement proved only temporary. At the same time, Secretary Cortelyou quitted the new Department, which he had set into operation, in order to become Chairman of the Republican National Committee. The selection of his successor, Victor $\mathrm{H}$. Metcalf, a member of the House of Representatives from California, was determined largely by geographical considerations.

The Cabinet had now greatly changed its complexion since the 
death of President McKinley; and, inasmuch as the presidential election of 1904 was at hand, the critics of the administration, especially the Nation, were disposed to connect the shuffling with the political interests of Mr. Roosevelt. It could not be claimed at this juncture, that the ability of the Cabinet had increased; and it was easy to charge the President with making politics and not efficiency, the prime consideration. ${ }^{1}$ The Roosevelt administration will undoubtedly stand out as one conspicuous for political activity. Some of the Secretaries went onto the stump in I904; and the whole Cabinet in 1908. Duff Green would certainly have stigmatized it as a "traveling Cabinet" that went about on " electioneering perambulations," making Presidents and Governors, instead of attending to its proper duties. It could not be charged, however, that the Cabinet officers were made and unmade with reference to their dexterity in turning the patronage to political ends, or in redemption of political pledges. Neither would the exclusion of those men who have charge of the policies of the administration, from the right to explain them to the people, appeal to the best judgment of the country. Even the Nation admits that this is a legitimate function, and sometimes a highly desirable one. Less than a month before the presidential election, Postmaster-General Payne, whose appointment had been especially viewed as a political one, was permitted to retire, having incurred public criticism for coming into collision with the Civil Service Commissioners, and for other causes.

The early months of Mr. Roosevelt's second term of office saw another Cabinet reconstruction; and although the distinguished figure of Secretary Hay was now lost, the administration, on the whole, gained in strength. It also assumed a peculiarly representative character, not of geographical sections, but of types of American citizenship. Mr. Cortelyou, after conducting the presidential campaign in a manner that was at the same time clean and vigorous, reentered the administration as Postmaster-General, the brief incumbency of Robert J. Wynne of Pennsylvania having intervened since the retirement of $\mathrm{Mr}$. Payne. Charles J. Bonaparte of Maryland, a lawyer of standing, succeeded Paul Morton in the Navy Depart-

${ }^{1}$ The Nation, LXXVIII, 504. 
ment. Being a leading Civil Service reformer, Mr. Bonaparte gave to the administration a tinge of what Bristow, Schurz, and Wayne MacVeagh had stood for in the 'Seventies and 'Eighties, when those principles were the subject of greater and more necessary agitation. In religion, Mr. Bonaparte was a Roman Catholic. The death of Secretary Hay, in July, I905, vacated the State Department, and ended one of the most brilliant careers in the history of the Cabinet. But the vacancy was most satisfactorily filled. Elihu Root, who had shown himself, by his late incumbency of the War Department, most efficient as an Executive officer, and superior to any of his colleagues as an intermediary between the administration and the country, set aside his professional interests a second time to enter public life, and became Secretary of State. From this time on, Secretaries Root and Taft, and Attorney-General Moody, until his resignation, enjoyed in the public mind the distinction of possessing a more than ordinary share of the President's confidence.

This series of changes, transfers, and promotions called forth from captious critics its due measure of condemnation. The Nation commented as follows: "We think that the real importance of the Cabinet in our system has been clouded of late. A tradition of ' loyalty' to the President has grown up, which too much tends to degrade the Secretaries into echoes and adulators. But the truest loyalty of a Cabinet member lies in giving his chief unflinchingly both advice and frequent doses of what it is so hard for President or Czar ever to hear, to say nothing of acting upon it-plain truth." 2 In ascribing the tradition of "loyalty" to a late date, the critic was in error; and equally so in supposing that the Cabinet was undergoing any eclipse. Certainly there were marks of a very vigorous and active presidential policy. If the abruptness that detracted from the President's popularity with Congress led to heated Cabinet episodes, their secrecy was preserved. The Loeb Letter of October, 1905, directed against the communication of Cabinet affairs to the newspapers, was apparently the occasion of a sharp discussion, and it was believed that the President modified the spirit of the order. It was only the manner of the order, however, that was peculiar to Mr. Roosevelt, for he

${ }^{2}$ The Nation, LXXXI, 26. 
was not the first President to caution his Cabinet about the newspapers. As a protector of his Secretaries against the kind of criticism that administrative reforms call out, Mr. Roosevelt showed himself the equal of any of his predecessors, and the superior of most. Secretary Hitchcock's vigorous administration of the Interior Department, especially in the Land Office, would not have been possible, without the avowed and persistent support of his chief. And Secretary Wilson was similarly sustained in the face of assaults upon the Department of Agriculture.

In the winter of 1906-'07, another reconstruction occurred. A vacancy upon the Supreme Bench made it possible for Mr. Roosevelt to honor Attorney-General Moody by elevation to that tribunal. At about the same time, Secretary Shaw was pleased to retire from the Treasury Department. Mr. Shaw had never been a great force in the administration. Since the monetary and fiscal legislation under President McKinley, the Treasury had been relatively of less importance than the State and War Departments; and it was believed, moreover, that this particular appointment was primarily intended to put a presidential candidate where he would not be formidable in 1904. Secretary Hitchcock's retirement was commonly accredited to his advanced years and failing health. In recasting the Cabinet on this occasion, Mr. Roosevelt allowed himself a particularly wide latitude in placing men where he wanted them, and in securing the desired personal types, regardless of geographical and other rules. Postmaster-General Cortelyou was promoted to the Treasury Department; Secretary Bonaparte of the Navy, to the Attorney-Generalship; and Secretary Metcalf of the Department of Commerce and Labor, to the Navy. The resulting vacancy in the Post-Office Department was filled by the appointment of George von L. Meyer, of Massachusetts, a man who had occupied two or three conspicuous diplomatic posts, and was especially qualified for Cabinet office on the social side. The Department of Commerce and Labor was filled by Oscar S. Straus, a prominent lawyer from New York. Mr. Straus was especially identified with the work of civic reform; and was independent in his political affiliations, having held a diplomatic office under a Democratic admin- 
istration. He was also a representative of the Jewish element. Secretary Hitchcock was succeeded in the Interior Department by James Rudolph Garfield of Ohio, a former member of the Civil Service Commission, and Commissioner of Corporations under the Department of Commerce and Labor. Mr. Garfield was the youngest member of the Cabinet; and was conspicuous for his high political ideals.

The Congressional session of 1906-'07 took action upon the salaries of Cabinet officers. Until I853, there had been different grades of emolument; but after that the Departments had been equal in this respect. By the original provision, the Secretary of State and the Secretary of the Treasury received $\$ 3,500$; the Secretary of War, \$3,000; and the Attorney-General, \$1,500. After ten years, in I799, the salaries attached to the State and Treasury portfolios were raised to $\$ 5,000$; those of the War Office and Navy Department, to $\$ 4,500$; while that of the Attorney-General's office was made $\$ 3,000$. In I8I9, the Secretaryships were put upon one level at $\$ 6,000$; but the office of Attorney-General was left so low as $\$ 3,500$. The salary of the Postmaster-General was increased much faster than that of the Attorney-General; and when that officer began to sit in the Cabinet, it was equal to that of the Secretaries. By act of March 3, I853, all of the Cabinet salaries were placed at $\$ 8,000$. Finally, the act making appropriations for the legislative, executive, and judicial expenses for the fiscal year 1907-'08, increased the Cabinet salaries to $\$ 12,000$.

The last months of the administration brought additional changes of personnel. In June, I908, Secretary Taft was nominated for the Presidency; and his immediate retirement from the Cabinet indicates both the enormous increase in the duties of Department Heads, and the change in the mode of conducting presidental campaigns since the old Republican days, when Secretaries of State proceeded immediately from that Department to the Executive Mansion. The vacancy in the War Office was filled by the appointment of Luke E. Wright, of Kentucky, a choice prompted by a desire to recognize the South. Later Secretary Metcalf dropped out of the Navy Department; and Mr. Root, who was about to become Senator 
from New York, resigned the State portfolio in time to gain a brief respite from public life. These vacancies, which would presumably have been filled by ad interim designations under the earlier law on that subject, were provided for by the promotion of the AssistantSecretaries Truman H. Newberry in the Navy, and Robert Bacon, in the State Department. In its personal interest the Roosevelt Cabinet yields to no other. As to whether special significance attached to its official relations, the events are too recent to show. 
President.

WILLIAM H. TAFT, Ohio.

Vice-President.

JAMES S. SHERMAN, New York.

March 4, 1909 to - .

Secretary of State.

Philander C. Knox, of Pennsylvania; March 5, 1909.

Secretary of the Treasury.

Franklin MacVeigh, of Illinois, March 5, 1909.

SECRETARY OF WAR.

Jacob M. Dickinson, of Tennessee, March 5, 1909.

Henry L. Stimson, of New York, May 15, I9II.

AtTORNEy-General.

George W. Wickersham, of New York, March 5, 1909.

Postmaster-General.

Frank H. Hitchoock, of Massachusetts, March 5, 1909.

Secretary of the Navy.

George von L. Meyer, of Massachusetts, March 5, 1909.

SeCretary OF THE INTERIOR,

Richard A. Ballinger, of Washington, March 5, 1909.

WALter H. Fisher, of Illinois, March I3, I9II.

Secretary of Agriculture.

James Wilson, of Iowa, recommissioned March 5, 1909.

Secretary of Commerce and LABor.

Charles Nagel, of Missouri, March 5, 1909. 


\section{TAFT.}

The make-up of the Taft Cabinet had much that was unusual about it, and some things that outwardly were not easy to explain. In the first place, Congress resorted to a special dispensation on behalf of a prospective Secretary who was Constitutionally disqualified. The President-elect had chosen for his Secretary of State, Senator Philander C. Knox of Pennsylvania, formerly Attorney-General under both McKinley and Roosevelt. Some time after this choice had been announced, it was discovered that Mr. Knox had become ineligible for a Cabinet portfolio, under the clause of the Constitution that forbids any member of Congress to accept an office, the emoluments whereof have been increased during his term of service. A bill was at once prepared to reduce the salary of the Secretary of State to what it had been before the recent legislation upon the subject. This passed the Senate without a dissenting vote, and had also a wide margin in the Lower House, although the principle was not approved in all quarters. Still further, Mr. Taft selected for the Treasury portfolio, Franklin MacVeagh of Illinois, who was a man engaged in business on a large scale. Herein lay an irregularity after the fashion of President Grant's attempt to appoint A. T. Stewart, the merchantprince of his time to the same position, but in its size more like the case of Edwin D. Morgan, who was actually confirmed under President Arthur. It was understood that Mr. Mac Veagh had made conveyances of his business interests to other parties. And the appointment proceeded. New-made Republicans received more than ordinary honor. Mr. MacVeagh was by his traditions a Democrat, though with Pennsylvania connections. Between his assumption of the Treasury, and the pending tariff revision, there appeared to be no particular relation. The War Department was assigned to a still more doubtful party man, Jacob M. Dickinson of Tennessee. This choice, like that of Mr. Dickinson's immediate predecessor, pointed to a desire in the Republican party to break up the old sec- 
tional line. The Post-Office became a manager's portfolio again, falling to Frank H. Hitchcock, who had been Chairman of the Republican National Committee during the presidential campaign. Another feature was the retention of two members of the Roosevelt administration, Mr. George von L. Meyer, who was transferred from the Post-Office to the Navy, and Mr. James Wilson, who retained his former portfolio, the Department of Agriculture. Mr. Wilson's incumbency now bade fair to become the longest in the history of the Cabinet, being surpassed only by that of Albert Gallatin, as Secretary of the Treasury. So far as outwardly appeared, the other appointments were determined primarily by considerations of locality. New York contributed the Attorney-General, George W. Wickersham. Missouri furnished the Secretary of Commerce and Labor, Charles Nagle. The Secretary of the Interior, Richard A. Ballinger, came from Washington. It might have been remarked that by the Wilson, Nagle, and Ballinger appointments, the three portfolios that reflect especially the industrial and economic progress of the country, and to some extent, its geographical expansion, lay. decidedly towards the Newer West. In one case, this proved to be a sort of sectionalism that had disastrous results.

Mr. Ballinger was a lawyer of reputation, and his appointment to be Head of the Interior Department was indirectly a promotion from the General Land Office. Much ill-suppressed disorder had attached to the Department from its establishment in 1849. And the evils that had the greatest consequences had grown out of the exposure of certain bureaus to the "interests" that were exploiting the Great West. A movement for the Conservation of the National Resources, popularized by President Roosevelt, had now thrust it into the very forefront of Cabinet affairs for its administrative importance. But the new Secretary's course was animated by the contrary idea of speedy development of the country. The result was the BallingerPinchot controversy, which might well have been a scene from the Grant administration, acted over again, a generation afterwards. A subordinate in the General Land Office charged Secretary Ballinger with catering to corporation interests, especially in the management of the "Cunningham Claims," which were concerned with coal lands 
in Alaska. Mr. Gifford Pinchot, who was Head of the Forestry Bureau in the Agricultural Department, carried the accusations still further, charging unsuitable administration of the forest preserves. The assault upon the Interior Department reached the proportions of a Congressional investigation. The Committee exonerated the Secretary by a party majority, and Congress refrained from acting upon its report. In due time, Mr. Ballinger resigned. President Taft had shown himself the most loyal of chiefs in the protection of his unfortunate Secretary. But he appointed a Conservationist to succeed him, Mr. Walter L. Fisher of Illinois. A few weeks later a change occurred in the War Department. And in appointing Mr. Henry L. Stimson of New York, to succeed Mr. Dickinson, who retired to look after private business, the President improved the opportunity to cement the party factions for the approaching election. 



\section{PRINCIPLES OF CABINET MAKING.}

One of the most characteristic features of the American Cabinet is its relation or exposure to party methods and aims. This would be expected under such a strenuous and all-embracing party system as operates the American Government. It is an aspect that has been touched upon many times in the foregoing sketches of the Administrations; but merits further development by a summary of the principles and rules of Cabinet making.

The first of these is that the incumbents of Cabinet portfolios must hold the same political tenets as the President and the party that has elected hirn. the chiefs of opposing parties, Hamilton and Jefferson, pitted against each other. But, whatever Washington's original purpose was regarding a political balance in the Executive, he definitely committed himself to a party Cabinet, when Randolph retired from the State Department in 1795. John Adams, who was the first President to owe his election to a particular party, kept strictly within its ranks in choosing his official advisers; and this is the more significant, because the factional quarrel which followed his election was not unattended by overtures from the opposition. Still further, when the Government underwent for the first time a distinct change of principles, with the accession of Jefferson in I8or, it was not expected that any of the former Ministers would be retained; and none of them were. So soon, then, as the Presidency itself became a party office, political agreement between President and Cabinet was recognized as the prime rule to be observed in forming an administration.

Departures from this rule have been few. Apparent exceptions there have been, arising both from the shifting of party lines and individual cases of mugwumpery. Thus the virtual disappearance of parties during the interval when the old issues between Federalists and Republicans were giving place to new ones between Whigs and Democrats, brought men together in the Monroe Cabinet, 
who differed both in their earlier and later affiliations. The combination of hitherto opposing elements into the modern Republican party was attended by a similar situation in the Lincoln Cabinet. And Tyler's attempt to bring about a fusion of the disaffected elements of two parties is reflected in the anomalous mixture at the Cabinet table. The most conspicuous individual case is that of Walter $Q$. Gresham, who became Secretary of State under Cleveland in 1893, after he had been a member of Arthur's Cabinet in 1883 and I884, and had shown a strong candidacy for the Republican presidential nomination in 1888 . The attitude of the Republican party towards the South, since the Civil War, has led to several appointments that are apparent exceptions to the rule of political agreement. The Roosevelt Cabinet afforded the example of Luke E. Wright in the War Department, and that of Taft furnished a similar case in Jacob M. Dickinson. Indeed there is a tendency of late for the President to indulge in a Cabinet appointment, usually early in his administration, that shall mark him as the head of the Nation, rather than the head of his party. But such cases disappear as politicăl expediency becomes more pressing, as when President Taft began to call into his Cabinet prominent members of the faction whose insurgency had probably cost the Republican party the mid-term elections. There are only two instances in which men have been called into the Cabinet immediately from the opposition. Lincoln, the selection of Stanton to be his War Minister, set aside prime of Cabinet making in order to secure a particular man. The sequel was, however, that St changed his party. The other instance is the appointment M. Key by Hayes to be Postmaster-General, in which case the opo tion Minister preserved his old affiliations. The circumstances wh justify the overstepping of party lines in the administration are exceedingly rare; and nobody would advocate it as a practice, unless he were an Independent of the most visionary sort.

Not only is the Cabinet thoroughly identified with the political party that is in power; but it also changes with the President. Although Cabinet rotation began earlier than the application of the rotation principle to the mass of appointive offices, and is enduring longer, its definite establishment resulted from the same idea. Its 
beginnings were accidental, in that they resulted from the elevation of two Vice-Presidents, Tyler and Fillmore, to the Presidency, at times when factional divisions were so accentuated, that the change of President as thoroughly transformed the spirit of the administration as if there had been a change of party. Buchanan distinctly avowed the rotation principle, when he permitted Pierce's Cabinet to retire in 1857 , after a tenure of four years. At least one voice had been raised in the same cause in the Van Buren administration, when Secretary Woodbury volunteered to quit the Treasury, in order to avoid criticism for not allowing his fellow Democrats a fair chance to hold office. Cleveland apparently made an extreme application of the rotation idea, when on returning to office in I893, after an interval of four years, he recalled none of his former Secretaries. Were it known that any of them desired to return, this would seem surprising, because the same President treated other rules associated with the spoils system with a good deal of defiance. The continuance of Cabinet rotation, after the decline of the ultra democratic conception of public office, is to be explained partly by the appreciation that has developed of the importance of personal compatibility in the working of the Executive, and partly by the notion that a President is his predecessor's echo, unless he chooses new Secretaries.

But although a President is expected to form a Cabinet that shall reflect his individuality, he cannot wisely obtrude his private friendships upon official considerations. There have been a few cases of this sort. Jackson's determination to be personal in the selection of one member of his official household resulted in the absurd appointment of Major Eaton. Several Presidents who have been lawyers, have decorated their partners with Cabinet honors; Fillmore, Harrison, Cleveland, and McKinley, fall into this list. The most conspicuous instance is McKinley's elevation of William R. Day, to the Department of State, after that gentleman had served a brief novitiate as First Assistant-Secretary with Sherman for an honorary superior. In Grant's original Cabinet, the personal idea predominated; and it was at no time absent from his choices. While such appointments provoke unfavorable comments, for failing to bring strength to the administration, none has ever incurred official oppo- 
sition. Should they become frequent, however, practical obstructions would be brought to bear.

The President has always been constrained, furthermore, to form his Cabinet according to a geographical code. In I795 Washington said, in the course of his search for a Secretary of State and an Attorney-General, that it had been his aim to combine geographical situation with ability and fitness. And the formation of an administration has continued to the present time to occasion much talk about Cabinet geography. The code has varied with the development of the country, the interests of particular sections, and the relation of the civil service to party politics. In the beginning the purpose was merely the identification of the Executive with the different quarters of the Union. The desirableness of such arrangement in a Union of States had been suggested in the Federal Convention, in George Mason's proposition to establish an Executive council of six members, two from the East, two from the Middle States, and two from the South. Political schemes began to enter into the geographical distribution, however, so soon as there was an occasion. As early as I80I, the conciliation idea is brought out by the liberal representation in the first Republican Cabinet of Massachusetts, a Federalist State. And a special recognition of political power is present in the precedence that was generally accorded to the four great States of Virginia, New York, Pennsylvania, and Massachusetts, over the other States in their respective sections.

Prior to the political changes that came with Jackson's administration, the double representation of a State was not seriously objected to, provided that portfolios of highest rank,-and there were three different grades at this time,-were not put together. Washington made the objection to a proposition that Chancellor Livingston should succeed Jefferson in the State Department, Jefferson retiring before Hamilton did, that to give the State and Treasury Departments both to New York would excite a newspaper conflagration. ${ }^{1}$ The portfolios were both of first rank; and New. York was not as yet the Empire State. Within this period, eight duplications actually occurred; but every one of them resulted from assigning the Navy De-

${ }^{2}$ Writings of Jefferson, I, 256. 
partment or Attorney-Generalship to a State that possessed a higher Cabinet office; and both of these portfolios were so undesirable that they had to be placed where they would be accepted. The preponderance of Virginians in the first administration, that State possessing the State Department and the Attorney-General's office, as well as the Presidency, is one of the indications that the members of the President's council were not definitely determined, when the appointments were made. Massachusetts held the Vice-Presidency and the War Office at the time; and New York the Chief-Justiceship and the Treasury. But the singling out of the three Secretaries and the Attorney-General to be councillors resulted in making the immediate administration very unequally balanced.

The expansion of the country, the democratizing of politics, and the great controversy between North and South developed new rules for the period which dates, in a general way, from Jackson's accession to the Presidency to the secession of the Southern States from the Union.

The appearance of Clay in the John Quincy Adams administration in I825 signalizes the admission of "the West" to the Cabinet table. Jackson included two Kentuckians and a Tennessean among the minions whom he placed there; and he also brought in the important figure of Cass from the North-West. Though Clay never appeared again as a Cabinet Minister, Crittenden took his place, whenever the Whigs were in power; while Ewing of Ohio, represented the NorthWest. In the later Democrat administrations, I853-'61, Cass continued to represent that section, once in person, and once by proxy. Prior to the Civil War, no State west of the Mississippi River furnished a Cabinet member, except that Edward Livingston of Louisiana was one of Jackson's later Secretaries of State. An offer was also made to Missouri by Fillmore.

The guiding principle, however, during this middle period was to preserve the balance between the slave-holding and the free States. The retarded enunciation of this,- - for it appears so late as the accession of Van Buren in 1837, coming from a Virginian, is doubtless due to the fact that the slave interest had hitherto felt no need of it; but that the Southern preponderance in the Executive was 
now threatened by the advancement of New York at the expense of Virginia. Henceforth until the Civil War, the rule was rigorously enforced; even Lincoln took two of his seven Ministers from loyal slave States.

So far as particular portfolios are concerned, the greatest significance has attached to the placing of the Treasury. From the passing of the Tariff Act of I824 to the Civil War, Pennsylvania, as the chief representative of the protection interest, contested this portfolio with the planter States of the South as regularly as the administration changed. She actually furnished five Secretaries of the Treasury during this period, none of whom had very much except locality to recommend them. The later Democrat Presidents, Polk, Pierce, and Buchanan, whose administrations were identified with the lowering of the tariff, all placed the Treasury portfolio in the South; but Polk had to conciliate Pennsylvania with the Kane letter. Lincoln was besought to assign the Treasury once more to the Keystone State; but preferring Chase over Cameron, he awarded it to Ohio.

Under the spoils system, the double representation of any State in the Cabinet was treated as a political anomaly; and this idea continued in full force until the accession of Cleveland in 1885. Seven instances arose during the interval from Jackson to Cleveland; but four were emergency cases, and three resulted from General Grant's naiveté about civil affairs ; all were of brief duration. In the exigency of secession, Buchanan called Stanton to the Attorney-Generalship, although he and Black, the Secretary of State, were both from Pennsylvania. However, upon the death of a Postmaster-General, two years before, Buchanan had avoided appointing Stanton, which Black had urged him to do, and continued to give that office to the South. A more interesting case occurred under Lincoln. When Hugh McCulloch of Indiana was made Secretary of the Treasury, John P. Usher, the Secretary of the Interior, but not a man indispensable to the administration, resigned in order to relieve an anomalous situation. Lincoln would have sacrificed the rule, however, in order to secure a necessary man; for he had offered the Treasury to Edwin D. Morgan of New York, before he did to McCulloch, though he would not have permitted Seward to resign in consequence. Grant 
startled official circles by making assignments of this sort at the very opening of his administration, when he was under no stress of emergency. Thus, it appeared during the brief incumbency of Washburne that both the State and War Departments were to be filled from Illinois. In the shifting that ensued, the Treasury was assigned to George S. Boutwell of Massachusetts, although E. Rockwood Hoar of the same State had been appointed Attorney-General. The irregularity caused Judge Hoar to delay his acceptance, and afterwards became a factor in his retirement.

Objections to double representation have sometimes been extended to the assignment of a Cabinet office to the State that had furnished the President. It is said that Lincoln was decided to appoint Norman B. Judd, his political and personal friend, to a diplomatic post instead of a Cabinet office, by the fact that Judd and himself both represented Illinois. And the story is in keeping with the caution that was exercised in forming the Civil War Cabinet. Mr. Blaine objected on this ground to the proposed retention of Sherman in the Garfield Cabinet, although an identical situation had existed betwen Sherman and Hayes. In actual practice, Presidents and Cabinet officers have come from the same State in many instances.

When the Whigs gave place to the Democrats in 1853 , a rule was given out by the party press, that a State which received a Cabinet office would not be given a foreign mission. ${ }^{2}$ And Buchanan demurred about accepting the office of Minister to England on the ground that Postmaster-General Campbell and himself were both Pennsylvanians, until he was assured that his acceptance would not jeopardize the sharing of his friends in other offices. ${ }^{3}$ The ex-Secretary's behavior is not entirely free from suggestions of sulkiness.

Since the Civil War, the geographical complexion of the Cabinet has been an index to the distribution of the party forces, even more than before. This is because political parties have been more compactly massed. A Republican administration, now gives the place enjoyed by the South during the slavery controversy to the West, reserving for the South only the complimentary recognition formerly

${ }^{2}$ Fish, The Civil Service and the Patronage, I74.

'Buchanan MSS. 
accorded to the newer parts of the country. The North-West, with its great pivotal States, is regarded equally with New York, Pennsylvania, and New England. Moreover, the Treasury portfolio, more disputed than any other, has become especially associated with this section, out of deference to the agriculture of the country, and the commercial interests that center at Chicago. From Chase to MacVeagh, the North-West has furnished eight Secretaries of the Treasury, two of whom have been members of two different administrations. Second in order, as a Treasury claimant, stands New York, the commercial capital of the country; but the discrimination of the law against Ministers of Finance, who are themselves engaged in trade has several times told against her candidates. Furthermore, the peculiar relation between the National Executive and the political organization within the Empire State seems to give to the latter a special claim upon the State portfolio, although the practice of making Secretaries of State out of presidential candidates militates against any definite location of that office.

Cabinet assignments were-extended to the Pacific Coast so early as 1872, when President Grant made George H. Williams of Oregon, Attorney-General. This did not occur again until McKinley appointed Joseph McKenna of California, to the same office in I897; but the Pacific States have since been represented in both the Roosevelt and Taft administrations. A modern Democrat Cabinet differs from a Republican one in that it reverses the distribution between South and West. In I885, there being seven portfolios at the time, Cleveland awarded three to the "solid South" and only one to the West.

The rule against the double representation of any State in the Cabinet has been greatly relaxed within a few years. This tendency began with the first Cleveland Cabinet, which, in other ways, rather tightened the grip of party rules. In forming his first administration, Mr. Cleveland assigned the Treasury portfolio to Daniel Manning and the Navy to William C. Whitney, both of New York, which State also furnished the President; furthermore, he appointed another New Yorker, Charles S. Fairchild, to succeed Mr. Manning, when the latter retired two years later. No President since that time 
has entirely avoided duplications of this sort. Harrison had two Indiana men in his Cabinet, in the latter part of his administration, John W. Foster, Secretary of State, and William H. H. Miller, Attorney-General. In his second administration, Cleveland again had two New Yorkers, Daniel S. Lamont, Secretary of War, and Wilson S. Bissell, Postmaster-General. McKinley had two Pennsylvanians for a short time, Charles Emory Smith, Postmaster-General, and Philander C. Knox, Attorney-General. President Roosevelt outdid all precedent both in the number and duration of such appointments. For almost five years, Leslie M. Shaw and James Wilson, both of Iowa, sat together in his Cabinet, as Secretary of the Treasury and Secretary of Agriculture respectively. Within this interval, Elihu Root and George B. Cortelyou, both of New York, were Secretary of War and Secretary of Commerce and Labor for about a year; which duplication was renewed, when Mr. Cortelyou reentered the Cabinet in 1905 as Postmaster-General, and Mr. Root as Secretary of State. In 1907, New York received triple representation by the appointment of Oscar S. Straus to be Secretary of Commerce and Labor, Mr. Cortelyou being at the same time promoted to the Treasury Department. With Mr. Roosevelt himself a New Yorker, this was an unparalleled massing of Executive offices. With Mr. Shaw's retirement from the Treasury, the Iowa duplication disappeared; but its place was shortly filled by the appointment of James R. Garfield of Ohio, to be Secretary of the Interior, while William H. Taft, of the same State, was Secretary of War. The Taft Cabinet gave double representation to Massachusetts at the outset by the appointment of George von L. Meyer to the Navy Department, and Frank H. Hitchcock to the Postmaster-Generalship. And the Cabinet reconstruction brought in the additional cases of two members from Illinois and two from New York.

The relaxing of geographical rules must be favorable in the long run to securing greater ability in the Cabinet and better adaptation of the members to their particular offices. But the discarding of such rules, by making the Cabinet a less representative body, would impair its efficiency in another direction.

The representation of political factions is also one of the President's 
problems in establishing his administration. The demands of party chiefs sometimes run into the dramatic, though the public is usually denied knowledge of such affairs. Nobody has played the role of Cabinet dictator more successfully than Samuel Smith; and nobody has assayed it with greater determination than Roscoe Conkling and Thomas C. Platt. Presidents have not often submitted to dictation of this sort; though Madison is a clear example. Public sentiment supports the President in making his own choices. However, when the party is divided by great personal interests, to ignore them in the Cabinet would jeopardize the influence of the Executive with Congress. A seriously disintegrated condition is sometimes met with a so-called "coalition" Cabinet, which brings together the chiefs of the opposing factions or their representatives. John Quincy Adams, Lincoln, and Garfield saw fit to follow factional lines very closely, but none of them yielded to pressure in their choices.

The incompatibility between Executive office and a seat in the Senate is a restriction upon the President's power to secure the Secretaries that he desires. In the Cabinet reconstruction of I795, the name of Richard Potts, Senator from Maryland, came up between Washington and Hamilton, in connection with the State Department; but was dismissed with the question, whether it would be wise to weaken the Senate at that time. The problem that was encountered thus early is a constant one in Cabinet making. One of the common demands with which a President-elect is importuned is that he will find places in the Cabinet for men whom rival Senatorial aspirants wish to put out of the way. President Garfield was besought to render such aid both in Ohio and Pennsylvania. And there is no doubt that a demand of the sort was the foundation of the report that went out in November, 1908, that President Taft had reserved a portfolio for Theodore Burton of Ohio. The only instance in which a President is known to have used the Cabinet for such a purpose occurred in 1897, when McKinley assisted the election of Mark A. Hanna to the Senate by making Sherman Secretary of State.

The comparative attractiveness of a seat in the Senate and a Cabinet portfolio has been, to a great extent, a matter of personal. preference. The names of Clay, Oliver P. Morton, and Allison, on the 
one side are matched by those of Webster, Sherman, and Blaine on the other. For comparing the actual draught of the Cabinet upon the Senate with the cases where portfolios have been declined, or not offered for fear of such results, these are not sufficient data. There is no doubt, however, that the draught of the Cabinet upon the Senate has very greatly declined since I $885 .^{4}$

From the forming of the Jackson Cabinet in 1829 , to the completion of the first Cleveland Cabinet in 1885, the usual order was to take two or three members out of six or seven from the Senate. There is no direct proof that this was a conscious rule; but special explanations for departures from it are easy to find. Thus Van Buren did not make a new Cabinet; Pierce was limited to Senatorselect by a new salary act; and Grant was ignorant of the ways of government. Senator Hoar's criticism upon Grant's Cabinet, that it was not drawing sufficiently upon Congress to secure the requisite working connection, indicates that the taking of a part of the Cabinet from Congress was expected at the time.

But the feeling about this seems to have changed. A change of attitude towards Cabinet office on the part of Congressmen, and Senators especially, is not the only cause of this. But some considerations which make Congressional leaders hesitate to enter the Cabinet have more weight than formerly. The increased importance of the social

"The extent to which Presidents have taken Senators and Senatorselect for Cabinet officers appears from the following: John Adams (I800) Samuel Dexter; Madison (1814) George W. Campbell; Monroe (I823) Samuel L. Southard; John Quincy Adams (1825) James Barbour; Jackson (1829) John Eaton, John Branch, John M. Berrien (1831) Edward Livingston (1834) John Forsyth; Van Buren (1838) Felix Grundy; William Henry Harrison (I84I) Daniel Webster, John J. Crittenden; Tyler (I844) William Wilkins; Polk ( I845) James Buchanan, Robert J. Walker; Taylor (I849) John M. Clayton, Reverdy Johnson; Fillmore (1850) Daniel Webster, Thomas Corwin; Pierce (I853) Jefferson Davis; Lincoln (I86I) William H. Seward, Salmon P. Chase, Simon Cameron ( 1864) William P. Fessenden; Johnson (1865) James Harlan; Grant (1876) Lot M. Morrill; Hayes (I877) John Sherman, David M. Key; Garfield (I88I) James G. Blaine, William Windom, Samuel J. Kirkwood; Arthur (1884) Henry M. Teller; Cleveland (I885) Thomas F. Bayard, J. Q. C. Lamar, Augustus H. Garland; Cleveland (I893) John G. Carlisle; McKinley (1897) John Sherman; Taft (1909) Philander C. Knox. 
side of the Cabinet, while being an added attraction, is also known to have been a hindrance to two or three men who were strongly marked for particular portfolios by their work in Congress. A more serious hindrance is the greater uncertainty of Cabinet tenure. While a degree of permanence attaches to a seat in the Senate, Cabinet office, unless it be opportunely quitted, retires men from public life. And it is not only with the Senate that the Cabinet has had to compete; for it has always been liable to decimation through resignations to accept diplomatic and judicial appointments. And the rule of rotation has added new force to the objection that the Cabinet is likely to be the end of a career. A few cases of retention by Roosevelt and Taft from the Cabinets of their predecessors faintly suggest a relaxing of the latter rule.

The relation of the Cabinet to the presidential succession at different times has had an effect upon the estimation in which Cabinet office was held, and has also determined whether specific appointments should or should not be made, especially to the State Department. Under the early Republican regime, the Cabinet was the immediate stepping stone to the Presidency; and the public mind was even more deeply impressed with the fact than the few instances of succession, and the competition of other candidates justified. It was this consideration that precluded the advancement of Gallatin to the State Department in I809. It was this again that determined the appointment of John Quincy Adams in I8I7, and at the same time prevented the promotion of Crawford. Although the contested election of 1824 pointed to a more democratic order, it was the political efficacy of the State Department that moved Clay to prefer it to the Speakership. Jackson and Van Buren excluded presidential aspirants from the Cabinet; and Polk avowed the exclusion principle, but enforced it very imperfectly. While the Whigs did not adopt the rule of the Jackson Democrats, their preference for military heroes for presidential material made Cabinet service of little avail; and Clay came to look upon the State Department as a good place for shelving Webster. With the multiplication of presidential aspirants, it became a frequent practice to put unsuccessful candidates for the nomination into the Cabinet. John Quincy Adams had set an 
example in I825; and Harrison's course in I84I was still more a case in point. Candidacy for the nomination was a leading consideration in the appointment of Seward, Blaine, and Bayard respectively, to the State Department. It is obvious that this way of selecting Cabinet officers is closely related to the principle of factional representation. The connection between Cabinet office and the presidential succession has never been obliterated from the public mind, although its influence has largely faded away at times. Heads of Departments have, from time to time, shown a candidacy of some strength, as Bristow in the Grant Cabinet, and Sherman in the Hayes administration. So recently as the calling of Mr. Root to the State Department in 1905, there was discussion as to whether he was not to be the administration candidate for the Presidency; and later both Mr. Taft and Mr. Cortelyou were added to the list. Mr. Taft's election, though it be but an isolated instance of return to the old Republican order, will probably be not without effect in commending Cabinet service to ambitious men. It has never been seriously proposed to put an ex-President into the Cabinet.

The foregoing topics lead up to the subject of the sources from which Cabinet officers are supplied. The American Government knows no Ministerial class. Under our dual system, with its separation of Executive and Legislature, it is impossible that any particular department of the public service should become a reservoir of Ministers in such a sense as the Houses of Parliament are under the British Government. The regime of the old Republican party, being a time of comparatively long tenures and of high prestige at least for the upper Cabinet offices, affords a half suggestion of the English way of forming a Ministry. But Cabinet rotation has been unfavorable to the existence of any limited group of potential Ministers. Since the Jackson era, the appearance of a Cabinet officer in more than one administration, whether by retention or recall, has been unusual. About eighteen instances can be enumerated, not counting cases of retention by accidental or reelected Presidents. The Fillmore Cabinet repeated that of the first Harrison in the State Department and the Attorney-General's Office; and the Cabinet of the second Harrison repeated that of Garfield in the State Department and the Treasury. 
Of that large majority of Cabinet officers, who have had some previous training in public affairs, the greater part have served the National Government. The Cabinet rolls are almost equally divided between former members of Congress and men without experience in that body. Although the period of membership has been too short, in very many instances, to secure any important position in the working organization, the Committee Service has perhaps outranked every other place in the Government, as a training school for Department Heads. The most conspicuous connection of this sort, both for the number and the prominence of the Secretaries furnished, lies between the Treasury Department and the great Financial Committees. Very striking examples are found in Gallatin and Sherman; and a less distinguished group includes the names of Crawford, McLane, Walker, Fessenden, Boutwell, and Windom. The diplomatic service has very frequently been the preliminary to Cabinet appointment; and such brilliant Secretaries of State as John Quincy Adams and John Hay have had an important part of their training there. Mr. Hay had also been Assistant-Secretary of State.

Immediate promotion from within the Departments is an important way to secure heads, very important, when measured by the number of instances in which it has happened, but less significant, when circumstances are taken into account. Two Assistant-Secretaries of State have risen directly to the headship, William R. Day under McKinley, and, for a very brief period, Robert Bacon under Roosevelt. In the Treasury Department, two Assistant-Secretaries, two Comptrollers of the Treasury, and one Comptroller of the Currency have risen to the head; the cases being William A. Richardson, appointed by Grant, Charles S. Fairchild, appointed by Cleveland, Oliver Wolcott, appointed by Washington, Walter Forward, appcinted by Tyler, and Hugh McCulloch, appointed by Lincoln. Five Assistant-Postmasters-General have been similarly advanced, one by Buchanan, one by Johnson, a third by Grant, the fourth by Arthur, and the fifth by Taft. The Interior Department has the instance of Assistant-Secretary, John P. Usher, which occurred under Lincoln, and a somewhat similar case in the transfer of James R. Garfield from the Commissionership of Corporations in the Department of 
Commerce and Labor to the headship of the Interior Department by Roosevelt. The Navy Department affords the case of the promotion of Truman H. Newberry from the Assistant-Secretaryship, also in the Roosevelt administration. Promotions from the bureau service and other subordinate offices would swell the list. It is a striking fact, however, that very few of these cases have been original appointments, and that some have been mere expedients for supplying vacancies during a remnant of an administration.

Another form of promotion arises from the changing of Cabinet officers from one Department to another; since this shifting is almost always upward, according to the order of rank observed in the Presidential Succession Act of 1886 . There have been about twentyfour immediate transfers and about eleven by recall. In some cases the purpose to advance an officer is very clear, as when Mr. Cortelyou was raised from the Postmaster-Generalship to the Treasury in 1907. But in others geographical rules have been the real consideration. Thus the Head of a Department has sometimes been transferred to one newly vacated, merely to fit the vacancy to an appointee from the section of the country whose representative is retiring. A clear illustration is found in the repeated transfer of John Y. Mason of the Tyler and Polk Cabinets. Mason was at first Secretary of the Navy; but in order to vacate that Department for George Bancroft, the chosen representative of New England, Polk advanced Mason to the Attorney-General's office to which Bancroft was not suited. The purpose is made the clearer, by Mason's return to the Navy, according to previous agreement, when Bancroft resigned; whereupon the Attorney-Generalship was tendered to two lawyers from New England, Franklin Pierce and Nathan Clifford, the second of whom accepted it.

There are several reasons why promotion has been a comparatively unimportant principle. Before the creation of the Assistant-Secretaryship, which preceded the Civil War by only a few years, Department subordinates were not ordinarily men of sufficient calibre to serve as heads, even temporarily. And, in the second place, the subordinate service has not been permanent enough to avail very much as a training school. Indeed promotion from the assistantships and 
the bureaus to the Cabinet would have been as much out of keeping with the most democratic conception of public office, as the long retention or reappointment of Ministers.

The Governments of the great States have contributed much to the training of Cabinet officers ; and have especially furnished a field for attaining the requisite political standing. Numerous ex-Governors appear on the Cabinet roll, distributed among all the Departments. Distinguished examples are found in Marcy, Chase, and Leslie M. Shaw. The State Judiciaries have contributed many AttorneysGeneral; and a considerable number have also been taken directly from private practice of the legal profession. Such names as Roger B. Taney, Jeremiah S. Black, William H. Evarts, and Richard Olney, the last three of whom were also Secretaries of State, show that lack of experience of the National Government is no disparagement to entering the Cabinet. The War Department has had a number of heads that have had military training, and have borne the title of "General." The names of Knox, Armstrong, Cass, Rawlins, Belknap, and Alger suggest themselves in this connection. Under Secretaries of this type, the administration of the office has ordinarily been indifferent, and sometimes notoriously weak; while the efficient Secretaries of War like Stanton, Root, and Taft, have been men of legal training. The Navy Department has very often been filled from private life. In its first years it seemed to seek merchants; and under the Jacksonians it became associated with men of letters, one of whom, George Bancroft, made a vigorous administrative officer. An especially varied group are the Postmasters-General, who include governors, judges, city postmasters, editors, and merchants, with the additional character of political manager frequently included.

Party services can hardly be denied a separate place as a qualification for Cabinet office. This practice borders on the unsavory one of using Cabinet portfolios for political rewards. In such cases, there is ordinarily an attendant expectation that the recipient will look after the political side of the administration. An early example of such appointment, and a very conspicuous one, is the elevation of Amos Kendall to the Postmaster-Generalship by Jackson in I835. The suitableness of the Post-Office for becoming a manager's portfolio 
is obvious. The recognition of party services was very noticeable in the formation of Cleveland's first Cabinet, when three of seven appointments, that of Manning to the Treasury, Whitney to the Navy, and Vilas to the Post-Office, were induced by political activities more than by any previously demonstrated fitness for Cabinet office. Especial criticism attached to Harrison's appointment of John Wanamaker to the Postmaster-Generalship ; because it was regarded as a reward for securing campaign funds. Although Mr. Cortelyou became Postmaster-General in the Roosevelt Cabinet, shortly after his direction of the presidential campaign of 1904, the appointment was also recommended by his previous incumbency of the Department of Commerce and Labor. The designation of Frank $\mathrm{H}$. Hitchcock, manager of the campaign of 1908, for the same Department under Taft, was also a promotion as well as a reward.

The latest tendency in the selection of Cabinet officers is to increase the proportion of men who are primarily distinguished for skill in administering large professional or business interests, and to place such men at the upper end of the Cabinet table more than formerly. This is the counterpart of the falling off of the draught upon the Senate, and a cause rather than a result of it. Perhaps the tendency is not marked enough or long enough continued to be very significant. Nevertheless, the preference for men who have proven their administrative ability, over those whose experience lies closer to the particular business of the Departments, is one of several indications that a new stage in the operation of the Departments has been reached.

The conformity of such an exalted body as the Cabinet to the tenets and rules of party practice has had important results. Early in the history of the Government, it hereby became an eminently democratic body; and it has substantially preserved such a character. Just because it has undergone a democratizing, the Cabinet has fulfilled, the more satisfactorily to the country, that conception of a guarantee that the President will not act hastily or unadvisedly, which underlay the agitation for the establishment of such an organ by the Constitution, and which has called out remonstrance, whenever its activities have been suspended. 
. 


\section{THE CABINET AND CONGRESS.}

A British authority on political science was recently heard to say: "One of the most difficult things for a Canadian, as well as for an Englishman, to understand in the United States, is how a Government can work that is not, by the presence of Cabinet Ministers in the Legislative body, in close touch with the law-making and moneygranting power from day to day. That it does work, we, of course, see." The present chapter will undertake to show how the Government of the United States does work in this particular.

The principle that those who administer shall guide in the making of laws is effectually prevented from working into the structure of the American Government, as it has done in England and some Continental countries. The modes of election render it possible for Executive and Legislature to be out of joint politically, though party activity renders such a deadlock a rare thing. The physical separation of these two great functions is established by the Constitution; for it is expressly provided that no person holding any office under the United' States shall be a member of either of the Houses of Congress during his continuance in office. ${ }^{1}$ The vote on this clause in the Federal Convention had no dissenting voices; and in the debates not one member distinctly advocated the system of fusion of the Executive in the Legislature. ${ }^{2}$ Men were looking for a safe-guard against Monarchical interference and Ministerial corruption.

In its outward forms, the separation has been enforced with much strictness. The Constitutional provision does not of itself exclude the great administrative officers from personal communication with Congress, or even from the privileges of debate. The President's Annual Message, under the Federalist regime, took the form of a speech from the throne. Both the President and the Secretaries of

${ }^{1}$ Art. I, sec. 6.

${ }^{2}$ Elliot, Debates, V, 420-424, 503-506. 
Foreign Affairs and of War communicated personally with the Senate in its Executive sessions, during the first few months after the Constitution went into operation. But the sufferance of Congress has never extended to such communication at a Legislative session. The subject has been agitated both in the first years of the Government and more recently. And the history of the agitation is important to an understanding of the real spirit of the American Government.

Alexander Hamilton succeeded in incorporating into the Treasury Act a provision for either written or oral commmunication from that particular Department, as Congress might direct. But, for the reason of greater convenience, his First Report was ordered to be submitted in writing. The question then fell into abeyance until the session of 1792-'93. And the practice of the Government was then determined, permanently, as it proved, by the defeat of a motion to summon two Secretaries, the Heads of the Treasury and War Departments, to attend upon the House of Representatives, and give information that would assist the investigation of the causes of the failure of General St. Clair's expedition against the Indians. The immediate animus of the decision was that the matter had become a party issue, the Republicans of the House, taking a stand, under Madison's leadership, against Hamilton's aggressiveness. ${ }^{8}$ The matter was scarcely heard of again for three quarters of a century.

While the Government was emerging from the disorders of the Civil War, a school of writers sprang up that denounced the existing methods of Congress, and advocated a closer union between Legislature and Executive. It presumably received its inspiration from the comparison between the "Parliamentary" and "Presidential" systems of Government presented by the English publicist, Bagehot, in his treatise on the English Constitution. The propaganda was almost entirely an academic one; but echoes of it reached Congress.

The exigency of the Civil War had already reopened there the question of extending the privilege of debate, in the House of Representatives, to Cabinet officers. February 8, I864, George H. Pendleton of Ohio, introduced in the House of Representatives a resolution, which led to the appointment of a special committee, that reported a

${ }^{8}$ Annals of Congress, III, 673-694, 696-70I, 703-708, 711-712. 
bill to provide for admitting the Heads of Executive Departments to the floors of the Lower House for the purpose of taking part in the discussion of measures relating to their own Departments. An extended historical argument accompanied the draft of the bill. This report pointed out that the exigencies of recent times had made members of Congress sufficiently familiar with the necessity for speedy and accurate information from the Departments, the very words, "conscription," "legal tender," and "taxation," being a reminder of the difficulties recently incurred." Fifteen years later, March 26, 1879, the question was brought up again, when Mr. Pendleton, who was now in the Senate, introduced a bill which provided for the admission of Cabinet officers to privileges of debate in both Houses of Congress. On this occasion, a very distinguished committee submitted a favorable report. ${ }^{5}$ January 5, I886, the question was revived for a third time, when Representative John D. Long, afterwards Secretary of the Navy, introduced a bill that provided for the voluntary attendance of the Heads of Departments upon the House of Representatives. None of these measures came to a vote, though the first two received an eminently respectable support. It was made very plain that Congress as a body did not desire a more direct connection with the Executive than that which had existed from the first years of the Government.

There is yet another chapter of events bearing upon the temper of the American people towards the fusion of the Executive in the Legislature. When the seceded states formed a government in I86I, a few of their leaders, consciously imitating a feature of the English Government, which was then furnishing a more admirable model than it had done three quarters of a century before, had their Provisional Constitution so framed as to render personal contact permissible. And President Davis made his Cabinet appointments in such a way that one half of the Department Heads were members of Congress. The Permanent Constitution of the Confederate States undid the arrangement to the extent of forbidding actual membership in Congress to Executive officers; but it made the compromise

'House Report 43, Thirty-Eighth Congress, First Session.

'Senate Report 873, Forty-Sixth Congress, Third Session. 
provision that Congress might by law grant to the principal officer in each of the Executive Departments a seat upon the floor of either House, with the privilege of discussing measures appertaining to his Department. But notwithstanding the approval of such a feature by men like Jefferson Davis, Alexander H. Stevens, and Robert Toombs, the Congress of the Confederate States failed to grant debating privileges to Department Heads. ${ }^{\circ}$

Notwithstanding the temper of American Legislatures towards personal union or fusion with the Executive, the principle that lawmaking processes require the guidance of administrative insight has made its contribution to the machinery of the Government. This is found in the high development of unofficial and informal means of connection. The lack of Ministerial leadership, Congress has supplied to it through the Speaker's office and the Standing Committee system." The great Committee of Finance in the House of Representatives, with which the Standing Committee system began, was erected for a barrier against the administrative officers. For, with both Houses comparatively small bodies, the Federalist Secretaries found personal access to the leaders on the floors far too easy to suit Republican sentiments. ${ }^{8}$ But the array of Committees that have been erected with the growth of Congress are recognized avenues of approach. Together with the irregular procession of Congressional leaders that visits the White House, they are the most important line of contact between the Executive and Legislature. The first advance is from the Committees' side ; and they are jealous for the Congressional prerogatives. It is for them to grant and not for Secretaries to demand audiences. But, when a Department Head has a plan to present,and it is only in their separate characters, that Cabinet officers are known to Congress at all,- - he can, under ordinary circumstances, secure a summons. The success of the hearing must, of course, depend upon a variety of conditions.

Very worthy of mention among the means of influence resorted to

'Journal of the Congress of the Confederate States of America, I, 182, 863; Constitution of the Confederate States of America, Article I, section 6, clause 2.

'McConachie, Congressional Committees, Appendix I, 35I-353; Memoirs of John Quincy Adams, V, 131, 227, 286, 303; VI, 450.

${ }^{8}$ Henry Adams, Life of Albert Gallatin, 157. 
by the Department powers are their social attentions to members. On this subject, there is an expression by Mrs. Jefferson Davis, herself a prominent Cabinet lady: "The wives of Mr. Pierce's Cabinet labored in their sphere, as well as their husbands. We each endeavored to extend hospitality to every member of Congress, of both Houses, at least once during the winter-If a measure was to be recommended by the Administration, the chairman of the Executive Committee, to whom these recommendations would be referred, were invited and the plan was informally unfolded to them. If a man was dissatisfied with the administration and not personally offensive in his disapprobation, he was invited to breakfast or some informal meal, where a personal explanation was possible." •

Cabinet officers have always enjoyed the privilege of the corridors and floors of the House of Congress. The diarist of the First Congress, William Maclay, Senator from Pennsylvania, refers to this frequently: "Mr. Hamilton is very uneasy, as far as I can learn, about his funding system. He was here early to wait on the Speaker, and I believe spent most of his time running from place to place among the members." There are some particularly graphic reflections of this practice of the time of the Polk administration. An opposition newspaper spoke out as follows on the passage of the measures that had originated at the Treasury: "The Heads of Departments feel that it is important to keep a vigilant watch over the doings of the Democratic members of Congress, fearing lest some of them, obeying the dictates of reason and conscience, might break loose from the trammels of party. When the final question was taken upon the Tariff Bill, the members of the Cabinet and Mr. Ritchie of the Union, all were present, closely scanning the sayings and doings of the members, and exerting all their influence to secure united action on the bill. It is stated also that during the discussion on the Land Graduation Bill, on Saturday in the House, every member of the Cabinet, except the Attorney-General, was on the floor, and expressed in various ways the interest they felt in the bill as an administration measure, and their presence saved the bill, or at least eked out its existence." 10 Still more engaging are the com-

- Jefferson Davis, Memoir by his Wife, I, 547 .

${ }^{10}$ Boston Journal. 
ments from the administration itself. President Polk wrote in his Diary in the session of $1846-47$ : "It was agreed that each member of the Cabinet should be active in seeing members of Congress and urging them to support the bill to admit California at once as a State. Buchanan, Marcy, and Toucey were to see members from the Northern States, Walker, Mason, and Johnson, from the Southern." And he recorded a little later: "The Cabinet met today; all the members present, except the Secretary of the Treasury, who wrote me a note stating - that the pendency before Congress of several important measures connected with his Department made it necessary that he should attend the Capitol and watch their progress through the two Houses."

The Congressional sufferance in these matters has been attended by a good deal of caprice. In the session of 1905-'06, a story went out that there had been words between the Secretary of War, William H. Taft, and a member of the Senate. The Senator upon encountering the Secretary on the floor, asked what he had come there for, to which the Executive officer replied that he was there, because it was his privilege and duty, but proposed that, if the Senator had scruples about such connections, it would be well for him to cease from his visits to the War Office, which were made to secure appointments and other favors.

There has always been a great deal of written communication between the Executive and Congress. The Constitution makes provision for the President's messages; neither does it limit them to information about the state of the Union, but includes the recommendation of such measures as he shall deem useful and expedient. The Department Heads exercise an analogous function, in making reports to Congress, though they are not so free to act voluntarily.

The early Congresses showed a good deal of captiousness about the matter of calls and reports. But it was, in the main, an attempt to curb the aggressiveness of the Treasury. Three spirited debates were provoked by motions to call for information, or to refer a communication from a Secretary. And one of these was a twin contro-

${ }^{11}$ Annals of Congress, III, 437-452, 673-694, 695-701, 703-708, 711-722; Annals for 1793-'95, pp. 1071-1080. 
versy with that which decided in the negative the question of summoning Secretaries to the floors of Congress. Attempts were made in these debates to enforce a distinction between allowing Department Heads to furnish needful information and suffering them to offer advice. It is particularly interesting to discover Madison, who had been for the first two sessions the champion and mouth-piece of the Executive power, now resorting to Infant Government arguments to justify his earlier stand, and maintaining that Congress had reached the age, when guidance by the Departments was superfluous. None of these motions for a call or reference was defeated, the majority perceiving that the practice was not one to be discontinued with the development of the Government. John Quincy Adams states that between 1800 and I820, the calls of Congress upon the Departments increased five-fold.

The practice of providing by law for reports from the Departments began with the Treasury. But statutes soon appear imposing upon the others the duty of reporting such matters as contracts; and other subjects were duly added. The general report from the Treasury addressed to Congress, and transmitted at the opening of the session, rests upon the supplementary Treasury Act of 1800 . The practice of including a sheaf of reports from the other Departments along with the Annual Message from the Chief Executive appears to have been instituted by President Monroe. ${ }^{12}$ Taylor added a report from the Secretary of the Interior upon the establishment of that Department. Annual reports from the Attorney General, the Secretary of Agriculture, and the Secretary of Commerce and Labor are provided for in the acts that establish their Departments. No general report is submitted by the Secretary of State, that officer's proper subject being reserved to the President in his Annual Message. Secretary Olney made such a report, and President Cleveland transmitted it to Congress in like manner with those from the other Departments. But the action did not establish a precedent.

The discrimination between information and advice, and between called for and voluntary communications, that frequently agitated Congress when modes of intercourse with the Departments were on

${ }^{12}$ Richardson, Messages and Papers of the President, II, 207. 
trial, looks absurd in the light of the freedom which Cabinet officers have enjoyed later, and which has been stamped upon later day statutes. Thus the Secretary of Agriculture is authorized by law to report on " special subjects," not only when the President or one of the Houses of Congress orders it, but, whenever he thinks that the subject in his charge requires it. And the Secretary of Commerce and Labor is required to make such recommendations as he shall deem necessary for the effective performance of the duties of his Department. However, the Senate passed reactionary resolutions on the subject of voluntary communications so recently as the session of 1907-'08.

The privilege of sending drafts of bills from the Departments to the official Congress has been exercised by particular Secretaries, but not distinctly conceded. And the latest action, like the earliest, is to prohibit such a direct initiative. In February, 1790, Hamilton, acting as head over the Postmaster-General, addressed to the Speaker of the House of Representatives, a bill for the organization of the Post Office. As the Clerk proceeded to read the bill, a member objected on the ground that it was improper for Executive officers to transmit bills to Congress; and the objection was sustained. ${ }^{13}$ The latest discussion on the subject occurred in the Senate in the session of 1907-'08. The occasion was the transmittal of communications from the Secretary of the Interior and the Acting Secretary of War, which enclosed drafts of bills. These were received on December Io, 1907, and duly referred to the Committee on Indian Affairs. On the following day, the reference was reconsidered by motion of Senator Aldrich; and an extended discussion of the subject of communications from the Departments ensued. The communications were next referred to the Committee on Rules. On January I5, Senator Lodge reported from that Committee resolutions against receiving any communications from Executive officers, except as specified. The list of precedents introduced in the discussion showed that the submitting of drafts of bills had been going on at least since 1874 ; and that such communications had been referred to appropriate Committees, under

${ }^{13}$ Annals of Congress, I, Appendix; Hamilton, History of the Republic, IV, 69. 
the order providing for communications from the Departments. It would seem from this that a means of influence, which the earlier Government had refused to allow, had crept in as a part of the increase of inter-communication that began with the Civil War. The result of the discovery was that the Senate passed a formal resolution against the receipt of any communication from Heads of Departments, Commissioners, Chiefs of Bureaus, or any Executive officers, except when authorized by law, or submitted in response to the order of the Senate, unless said communication was transmitted by the President of the United States. ${ }^{14}$

A good idea of the average operation of the Department influence in drafting legislation is given in the Manual of Congressional Practice, prepared in I890, by T. H. McKee, at one time Journal Clerk of the House of Representatives. Attention is herein directed to the annual publication known in the literature of the Government as a List of Reports to be made to Congress; and especial attention is called to the report of the Secretary of the Treasury entitled Estimates for Appropriations. It is asserted that this report becomes the basis upon which the Committee on Appropriations and other Committees charged with money-granting make up the annual estimates. The Mamual further asserts that it is the uniform practice of the Committees of both Houses of Congress, in the preparation of bills that relate to the administration of any of the Departments, for example on such subjects as Public Lands, the Indians, or Agriculture, to submit the proposed measure to the proper Department, and that the Executive officer's recommendation is usually respected by the Committee. This reference for emendation and revision is so much a matter of course, that prepared forms of transmission to the appropriate Departments are a part of the material of certain Committees. ${ }^{15}$

A more amusing discussion of a legitimate Cabinet influence comes from President Polk's time, in the form of an altercation between the Daily Union and the National Intelligencer. The dispute began about the Tariff Act of 1846 . This was distinctly an

${ }^{14}$ Congressional Record, Vol. 42, Pt. I, Sixtieth Congress, First Session, 243, 294-302, 714, 772.

${ }^{15}$ T. H. McKee, Manual of Congressional Practice, 290-292. 
administration measure. A tariff revision had been promised in the Democrat platform of 1844 . And so soon as the new administration was inaugurated, the preparation of a bill was begun without calling a special session of Congress. Secretary Walker of the Treasury addressed a circular to the great manufacturing concerns of the country for the gathering of data. His course was ardently commended by the Daily Union, which was the administration organ. And the desired precedent was declared to be found in a circular issued by Secretary McLane in 1832. But the National Intelligencer, being the chief organ of the opposition, warned the country that it might well look with jealously upon such attempts by the Executive to originate legislation, and especially tariff bills. The supposed precedent it ruthlessly broke down by discovering that the McLane circular had issued at the order of Congress. But shortly, both sheets found occasion to change their tack. The following year the army bills lagged. And it was whispered that the Mexican War was making Whig Presidents too fast to please the existing administration. The National Intelligencer laid the retarded legislation to the charge of the War Department. But the Daily Union exonerated that office of all remissness, by remarking that it was not considered the duty of a Department to prepare bills for a Committee, unless requested; and that it would be scarcely respectful to do so, inasmuch as the Committees were entirely qualified, in case they approved of Executive recommendation, to frame the proper provision for carrying it out.

The vocabulary of American law-making recognizes that there is an administrative influence. This has become so marked that a stranger visiting the country during the first regular session of the Sixty-First Congress, Igog-'ro, must have gained a wrong impression of the system of Government. Newspapers and magazines spoke constantly of " administration measures," coupled the name of the Secretary of the Interior with conservation bills, and traced corporation legislation to the Attorney-General's authorship. But it cannot be asserted that the administration initiative is increasing.

Along the whole course of American legislation, a few measures stand out as having an acknowledged administration origin. Ham- 
ilton was the obvious agent to institute the series of acts by which the National finances were organized. Congress, after bungling legislation for a session, appealed to the Secretary of the Treasury so soon as he was appointed. And plans for financial organization were forthcoming in the famous series of reports. The actual measures were introduced through the medium of special committees. So soon as this was accomplished, Hamilton's great influence upon the making of laws was at an end. The Republicans with their program for financial reforms, looked as naturally to the Head of the Treasury, Gallatin being their acknowledged master of finance. The Tariff Act of 1846 , referred to above, was left to the administration. It seems to have been a time of transition between modes of preparing such bills. And the most obvious Committees for such a work were not very strongly made up. A very interesting illustration of the dependence of Congress upon the Executive offices, when measures are framed that require technical and scientific information, is furnished by the Mint and Coinage Act of 1873. Preparatory to framing this measure, the previous coinage laws were codified by Deputy Controller John J. Knox, who was afterwards considered by President Garfield as a suitable Head for the Treasury Department. Secretary Boutwell directed the work, and himself transmitted the draft of a bill to the Chairman of the Senate Committee of Finance, John Sherman, with a statement as to how it had been prepared and a strong recommendation that it be passed. Some new features were grafted onto the bill after it reached Congress. ${ }^{10}$ With the McKinley Tariff Act of 1890 , Secretary Blaine was much concerned at the Committee rooms about the securing of "reciprocity" provisions, which were important to his South American policy. ${ }^{17}$ The "Logan Act," of the early years of the Government, resulted from the suggestion of the Secretary of State, Timothy Pickering. Webster, while Secretary of State in the Tyler Administration, drew up the measure that was passed to put an end to the dispute about the jurisdiction of the Federal Government that had been

${ }^{18}$ Sherman, Recollections of Forty Years, I, 463-467.

${ }^{17}$ Gail Hamilton, Biography of James G. Blaine, 682-698; Stanwood, James G. Blaine. 
raised by the McLeod Case. This call upon the Executive is interesting, because the administration had very little support in Congress. An abnormal co-operation is found in Secretary Stanton's participation in the framing of the Military Reconstruction Acts and of the Military Appropriation Act that curtailed the President's Authority over the Army. ${ }^{18}$ When a member of the administration is recognized as the most eligible person to frame a particular measure, he will ordinarily be called upon. But the history of the Executive participation in lawmaking will not permit a stronger statement of a Cabinet officer's opportunities to initiate.

More important than the isolated instances of admitted Executive origin is a great mass of legislation that is a fusion of the minds of administrative officers and members of Congress. Whether the Executive or Legislative is the more active element must depend upon the comparative strength of Presidents, Secretaries, and Congresses. But it can be categorically asserted, that in all subjects, where technical information is required, Congress grows more and more disposed to admit the influence of the Departments, as the Civil Service becomes more permanent and expert. The real place of President and Cabinet with reference to law-making lies between two extreme views. There is no movement towards a fusion of the two great branches of Government, as a few American publicists with Anglican leanings might hope. But, neither are the processes of legislation so bungling, and so unaffected by administrative insight and advice, as they appear to English critics, with their predisposition to hold the Cabinet system of Government superior to the Presidential-Committee system.

${ }^{18}$ Gorham, Life of Edwin M. Stanton, II, 373. 


\section{THE CABINET AND THE PRESIDENT.}

The paramount aspect of the American Cabinet is its place in the Executive. The foregoing survey of the Administrations has developed the subject of particular Cabinets and particular Presidents beyond that of ordinary Executive relations. But it has found its own justification in the discovery that the Cabinet is, to a very great extent, the resultant of the personal forces involved at any time, probably surpassing every other organ of the Government in the play that it allows to personal causes.

No concise classification of Cabinets is possible, and none whose lines do not seriously cross. Taking ability and actual participation in the operations of Government for a criterion, those that stand highest in the distance are, Washington's Cabinet-with its original members-Jefferson's, Polk's, and Lincoln's-in the form made familiar by painter and engraver in the Emancipation Proclamation scene. We leave out the Monroe Cabinet with hesitation, but on the ground that, outside of the State Department, the Executive was dormant, when tested by the fully awake condition of Congress. The level sinks lowest, though broken here and there by a more elevated figure, under Jackson, Van Buren, Taylor, and Grant. It is the normal situation that the ability of the more important Department Heads shall be at least commensurate with that of the President; this is induced by political necessity, if nothing else. There is a common type of Cabinet that masses its strength in the Secretary of State, but, under the Presidential System of Government, the Executive influence is best sustained, where there is less disparity among Department Heads.

Taking the relative influence of Cabinet and President for a criterion, at one extreme, stands the Cabinet regency with which the Buchanan Administration went out of office, and at the other the quasi-military regimen of Jackson and Grant, under which Secretaries were handled more like a General's orderlies than high civil 
officials. Between these there is a normal order, though it is not very rigidly defined. Officers with the talents and rank of Department Heads command a discretion that the Chief Executive does not interrupt, unless serious disagreement arises. And yet occasions for the assertion of the Presidential authority are too frequent for it to fall into abeyance. There are comments on this subject by two ex-Presidents, Hayes and Benjamin Harrison, which look at the matter from its opposite ends. Mr. Hayes, who by the way, had the abler Cabinet, makes a strong statement of the President's mastery, and the Secretary's subordination $;^{1}$ while Harrison states in larger terms the Secretary's freedom from interference. ${ }^{2}$

American Cabinet officers are not Ministers in the sense of the Constitutional Monarchies of Europe. It is chiefly by their responsibility to the President, and their exclusion from personal intercourse with Congress, that they fall short of that character. The Secretary of State approaches it more nearly than his colleagues. For, while the President is Minister of Foreign Affairs by the Constitution, he has often found it expedient to devote his activities to homelier matters, and adopt as his own the ideas of his exalted subordinate. Such Secretaries as John Quincy Adams, Webster, Seward, and Hay have originated and worked out a very important part of the diplomatic achievements of the Government. Still the President on occasion acts upon his own inspiration, and even independently of advice. Very fresh and convincing are some of the examples. In the decision to demand the Philippine Islands, at the peace negotiations betwen the United States and Spain, President McKinley proceeded contrary to the opinion of Secretary Hay. ${ }^{8}$ And the American intervention in the negations between Japan and Russia has had distinguished recognition as President Roosevelt's own act.

The Secretary of State enjoys a semi-fictitious headship over the Cabinet. To trace this to its origin, the earliest incumbent of the office, Jefferson, has put on record that it held first place, by the

${ }^{1}$ Stevens, Sources of the Constitution of the United States, 167, Footnote.

${ }^{2}$ Harrison, This Country of Ours, 105, et seq.

${ }^{8}$ Foster, Diplomatic Memoirs, II, 257. 
President's ranking, from the outset, though the source of this statement throws it open to suspicion of self-glorification. He represents Washington as saying, with regard to a proposition to put Governor Johnson of Maryland over the State Department temporarily, and afterwards transfer him to the Treasury, that men do not like to 'go from a higher Department to a lower one." But during the early Republican period, the distinction came to be very generally recognized. In I806, John Randolph, speaking to the House of Representatives, referred to the Secretary of the Treasury as the "Head of the second Department," though Wilson Cary Nicholas, writing to Gallatin in I809, of the proposed transfer from the Treasury to the State Department, said that he had been for eight years in an office "of equal dignity and of greater trust and importance." 5 Two years after the opening of the Monroe Administration, John Quincy Adams, in his consciousness of the political prestige attached to his office, noted in his Diary that a general impression now pervaded the country that a higher consideration was due to the State Department than to the others, and that in all legislative acts, this was now named first and the Treasury second." The name Premier occasionally used in unofficial parlance, was first applied, so far as we have noticed, to Webster, at the time when Tyler was breaking with the Harrison Cabinet.

As an idea or sentiment, the primacy of the State Department has undeniable force. It causes the portfolios to be reserved for the most statesmanlike talents and the strongest public character that a President can secure in his assistants. Sometimes it is the first portfolio to be assigned, and the prospective incumbent is allowed materially to assist in forming the rest of the administration. But so far as the processes of Government are concerned, the superiority eludes definition. Both an ex-President, Benjamin Harrison, and an ex-Secretary of State and ambassador, John W. Foster, have made it subject of comment. But neither of these gentlemen could point to any advantages enjoyed by the Secretary of State over his col-

\footnotetext{
"Writings of Jefferson, I, 258, Anas, August 6, I793.

${ }^{5}$ Henry Adams, Life of Albert Gallatin, 389.

- Memoirs of John Quincy Adams, IV, 297.
} 
leagues, other than a more closely guarded confidence with the President, rank in the succession next after the Vice-President, and ceremonial precedence." Before regular Cabinet days were observed, the Secretary of State was often, if not customarily, the President's summoner. There has been an occasional exception to the recognition of superiority in this Department. When the Hayes Cabinet was being formed, it was said that no priority was considered to attach to it. ${ }^{\mathrm{s}}$ And the issue proved that $\mathrm{Mr}$. Evarts did not impress himself upon that administration proportionately to his high standing as a Constitutional advocate. On the other hand, when the Garfield Cabinet was being formed, Mr. Blaine, and his family for him, entertained a very large idea of the headship belonging to the State Department.

The Treasury has receded very far from the character that Hamilton assumed and that Gallatin had thrust upon him. The office of Secretary of the Treasury has not realized the possibilities that were thrown about it by the early statutes; but has come to share the role of Minister of Finance with the Chairmen of the great Financial Committees of Congress, especially of the House of Representatives. In the factional rivalries of Cabinet making, the Treasury portfolio has been more fiercely contested than any other. But desire to command the office does not find its explanation in power to frame the fiscal and commercial policies of the country. The first incentive is opportunity for influence in the distribution of the patronage; and a second, the fact that the commercial and fiscal regulations of the Government depend a good deal upon the spirit in which they are administered. The Secretary of the Treasury is at least a great administrative officer. Indeed these are the considerations that cause Cabinet appointments in general to be received with interest, whole Cabinets much more than the changes that occur separately. Political shading comes first. But beyond that, an index to the President's policy in some matter is frequently read in the

\footnotetext{
'Harrison, This Country of Ours; Foster, A Century of American Diplomacy.

${ }^{8}$ Reminiscences of Carl Schurz, III, 374.

' Gail Hamilton, Biography of James G. Blaine, 530.
} 
placing of a man who stands for a particular idea, where he can carry it out in administration.)

Characterization of the Cabinet on a chronological basis traces a very fluctuating line. Furthermore, the line shows no advancement, beyond the natural results of increase in the size of Government operations. Growth there has been, but no development of function. There are two principal causes of this. One is the fact that Congress has preserved its separateness from the Executive rigidly and persistently; the other, that the Presidency has developed to the disparagement of the Cabinet.

In the first place, the President has exercised the powers of appointment and removal with an energy far beyond the expectation of those who conveyed them to him. And he has made them an instrument for enforcing his will over his official advisers. The removal power was applied to Cabinet office very early. And by the sharpening that it received of the spoils system and rotation principal, the conception of the President's personal ownership of the Cabinet was carved out. With this notion in men's minds, the right to dismiss Secretaries has been conceded to the President much more unreservedly than before. It has always been subject to practical limitations, especially political expediency. Excessive shuffling of portfolios remains a matter of criticism. But the present day caviling of newspaper editors is a mild substitute for the aspersions upon the President to which deposed Secretaries formerly resorted, and the acrimonious discussion that ensued.

In dealing with such high officers as Department Heads, the removal power has been very delicately applied. Technically there are only two removals in the history of the Cabinet-the dismissal of Pickering by John Adams, and that of Duane by Jackson,- -if it be held that the retirement of Stanton was effected, not by the President's prime order of dismissal, but by the Secretary's resignation after the failure of the impeachment of the President on that issue. But virtual removals, couched in the polite phrases of resignation and acceptance, are numerous, probably more so than anybody knows, since there may well be cases, in which retiring Cabinet officers have succeeded to second or third class diplomatic posts, or 
to inferior judgeships, without knowledge on the part of the public as to whether the change was more desired by Secretary or President.

The power has been applied for a variety of purposes. It was put into operation, in the first place, as a penalty for insubordination, when John Adams dismissed Pickering and McHenry. During the troubles of Madison's administration, especially the War of I812, incompetency was the great cause of the many dismissals from the Cabinet. Indeed the Mexican War is the only one in which the United States has been engaged, that has not discovered that the Secretaries charged with the administration of the defences were at their best in time of peace. In 1862, Cameron had to be dismissed; and in 1898, the Alger case arose. Jackson ridded himself of McLane and Duane, because their theory of the powers of their office clashed with his. The removal of Postmaster-General Blair by Lincoln was a presidential campaign measure. And in the period of unsavory politics that set in after the Civil War, Cabinet removals for political ends were common. Johnson deserves credit that he has never received for refusing to have his administration unmade and remade to suit the demands of the party managers. But Grant freely permitted the manipulation of his council board; and such figures as Ebenezer R. Hoar, Jacob D. Cox, Marshall Jewell, and Benjamin Bristow were made to give place to men who would exploit the political resources of the Departments more acceptably.

The President's power to appoint his own Secretaries is subject to various political rules, and to the Constitutional check of confirmation by the Senate. The first of these limitations is the more seriously felt. Geographical and kindred considerations sometimes exclude men whom the President would otherwise place over Departments. The ability of the Cabinet, and the adaptation of members to their portfolios is impaired by such restrictions. But the field for cheice is not so much narrowed that the President is constrained to take incapable men, or men that are likely to prove intractable. Some of the rules that have grown out of the spoils system have been to the President's advantage in his relations to his Cabinet.

The possibilities of the Senatorial check are much greater than 
the actual results. In the early years of the Government, whenever there was change of administration with change of principles, there were fears, if for any reason the party majority in the Senate was uncertain, that the confirmation of the Cabinet would be made an occasion for a party vote. Expedients for averting the danger were sought by both Jefferson and Jackson. An incoming Cabinet has occasionally been opposed by resistance to some particular member, in the form of delay, or a small adverse vote. But only once has an entire Cabinet slate been obstructed. And this was a sequel to the doubtful Hayes-Tilden election, and a manifestation of factional disaffection. The intervention of public opinion had a salutary effect. Four years later, President Garfield ventured to appoint a Secretary of the Treasury in opposition to the persistent demands of Senator Conkling and his faction, and the appointment was confirmed without delay, though the filling of one of the great offices within the Department precipitated a few weeks later a memorable struggle for the rights of Senators. At the next change of administration, a Republican Senate confirmed a Democrat Cabinet for President Cleveland. A new administration has a strong assurance of a fair trial under all circumstances.

The reconstruction of Cabinets has been more seriously hampered than their inauguration, because change of Secretaries has frequently been a means of carrying out some purpose that has aroused opposition. In Madison's administration, the changes fell foul of jealousy over the management of the War of I8I2, and the political rivalry between the Northern States and Virginia. Jackson invited opposition in the first place by breaking with Calhoun, the VicePresident, and later by his anti-bank policy. He was able, however, to plough around it by clever use of his vacation powers. Tyler's difficulties with Cabinet appointments were largely of a personal nature. Three times the Senate has prevented Cabinet nominees from taking their seats. And three times has it unseated officers who had been installed at the Cabinet table during its vacation. It is known that its power to reject has on a few occasions prevented Cabinet nominations. But the proportion of cases in which the Senate has asserted an effective opposition is very small. 
It is a conclusive commentary upon the importance of the powers of appointment and removal to the ordering of the Executive, that they have been the centre of attack in every movement on the part of Congress to put a curb on the Presidency. ${ }^{10}$ In the earlier Republican period, an amendment to the Constitution was proposed that should take the power of appointing all Cabinet officers away from the President, and convey it to the two Houses of Congress. And a second proposition of the sort was brought up that contemplated the single Department of the Treasury. Then came a series of efforts in the same direction that were provoked by some of the memorable quarrels between President and Congress. Jackson's assertion of authority over the Treasury set in motion a series of propositions, which were brought forward by Clay in the Senate, and by a member of his delegation in the Lower House. Tyler's vetoes called forth a renewal of these propositions, Clay being again the protagonist. The actual infringement upon Johnson's power to control his Cabinet is matter of common knowledge. A few days after the Cabinet proviso of the famous Tenure-of-Office Act was repealed, a proposition was introduced to continue some restriction of the sort by Constitutional amendment. The limitation of the President's powers of appointment and removal, so far as the members of the Cabinet are concerned, has not appealed to the sober judgment either of Congress or the country. But on the contrary, all plans for Civil Service Reform have retained and emphasized the immediate control by the President of his official advisers.

It is a matter of some consequence that the Cabinet has grown from four members to nine, but it is of very little moment, compared with the fact that not a single addition has been made at variance with the rule of removability by the Chief Executive. The Vice-President has not been admitted to the Executive Councils, although the suggestion is sometimes heard to give him something more to do than handle the gavel in the Senate by making him a sort of Minister without a portfolio.

In the second place, it has been detrimental to the freedom of Cabinet officers, and indirectly to the powers of the Cabinet itself,

${ }^{10}$ Ames, Amendments to the Constitution, I3I-138. 
that the Presidency has developed an almost unlimited power of direction over the array of business that Congress imposes upon the Departments by specific statute. The Constitutional grant of Executive power has, in a sense, its "elastic clause." And the prevailing construction of the provision that the President shall see that the laws are faithfully executed, is the one most favorable to that branch of the Government. The decisive battle over the President's administrative powers was fought in the Jackson era. The particular form in which the narrower view of the Presidency expressed itself at that time was that the Departments are divided into two groups, of radically different nature. It was held that the Treasury and Post Office were agencies for the performance of functions that lay by Constitutional arrangement within the ordering of Congress, and were not Executive Departments at all. The State, War, and Navy Departments, on the other hand, correspond, in part of their extent, to fields that lay within the powers of the President, as enumerated in the Constitution. A very clear-cut statement of this doctrine is secured by combining Clay's arraignment of Jackson in the Senate for taking into his own hands the law that clothed the Secretary of the Treasury with a discretion about the deposit of the Government funds, ${ }^{\text {" }}$ and the argument before the Supreme Court, in the case of Kendall v. United States, to show that a mandamus issued against Postmaster-General Amos Kendall, to compel that officer to complete certain contracts entered into by his predecessor, ought to be sustained. ${ }^{12}$ We consider this position largely a partisan one. Very respectable authorities on political science hold that it is in line with the original view of the powers vested in the Presidency. But the minute investigation of the early status and condition of the two Departments, requisite to prove this, has not been made, to our knowledge.

Very different from this doctrine, and yet entangled with it in some of its applications to cases, is the recognition of a distinction between two different fields in every Department, in one of which the Department Head is the agent of the President, and controllable by him only, while in the other he is a public officer of the United

${ }^{11}$ Congressional Globe, 1833-1835, pp. 54-57.

${ }^{12}$ I2 Peters, 570, et seq. 
States, amenable to the laws for the performance of his duties. The Courts have recognized the latter character, whenever they have issued a writ of mandamus against a Cabinet officer. Chief Justice Marshall laid down this distinction in the case of Marbury v. Madison. ${ }^{13}$ Though the passage is much quoted, it is not so lucid as the argument of Charles Lee, who was counsel for Marbury, and previously Attorney-General to both Washington and John Adams. The particular officer in question was the Secretary of State. And Mr. Lee laid down that he exercises his functions in two distinct capacities; and that the difference is clearly illustrated by the two acts of Congress, establishing the office. Under the greater act, which constitutes the Secretary in question an agent to conduct the Foreign Affairs of the Government at the President's order, he is responsible only to the President. But, under the supplementary act, which makes him Keeper of the Great Seal, and Custodian of the Records of the United States, he is a public ministerial officer, executing duties enjoined by law, and uncontrollable by the President of the United States. ${ }^{14}$ Obviously this position would be unfavorable to the President's power of direction, accordingly as the line was drawn between the two fields.

Opposed to these restricted views in whatever form, is the theory of the Executive that is particularly associated with Jackson's name. We quote from his protest against the resolutions of censure passed by the Senate upon his conduct in taking the removal of the Government deposits from the Bank of the United States into his own hands: "The whole Executive power being vested in the President, who is responsible for its exercise, it is a necessary consequence that he should have a right to employ agents of his own choice in the performance of his duties, and to discharge them, when he is no longer willing to be responsible for their acts" . . . And, "it would be an extraordinary result, if because the person charged by law with a public duty is one of his Secretaries, it were less the duty of the President to see that law faithfully executed than other laws enjoining duties upon subordinate officers or private citizens."

\footnotetext{
${ }^{13}$ I Cranch, 164.

${ }^{14} \mathrm{I}$ Cranch, 137, et seq.

${ }^{15}$ Richardson, Messages and Papers of the Presidents, III, 79, 84.
} 
Judicially, the points controverted between theories of the Executive have not been fully covered. But in practice the power of removal renders and sustains a clear verdict in the President's favor. Very valuable testimony to this fact is furnished by the Tenure-ofOffice Act itself, or rather by the attitude of the members of Congress towards that act. It was not the original purpose that the check put upon the removal power should operate to enjoin the President from changing his Cabinet officers; but when the policy of Military Reconstruction was resolved upon, the obvious way to secure an unimpeded administration of that policy was to make the Head of the War Department irremovable by the President. ${ }^{16}$

Jackson's triumph over two intractable Secretaries of the Treasury was none the less real for the temporary censure of the Senate, or the refusal to confirm the vacation incumbent, after the work for which he had been installed was done. Jackson's successors have pushed the presidential direction over the Treasury still further without incurring opposition. There have been some especially conspicuous applications to this Department of the President's power to recommend to Congress such measures as he shall judge necessary and expedient, notably in President Cleveland's messages. The Sundry Civil Bill of March 4, 1909, contains a provision that is very strikingly at variance with the theory that the Treasury is an establishment outside of the Executive control. It is herein provided that the Secretary for the Department, upon receiving estimates of expenditures for the fiscal year, shall prepare an estimate of revenues, and report all discrepancies between the two to Congress so soon as it assembles; but that he shall also acquaint the President with the facts in order that the latter officer may make suggestions to Congress as to where appropriations could be cut down, or advise new taxes or loans. ${ }^{17}$ Whether it has become the practice for the President to exercise the same authority over the Secretary of the Treasury's reports as he does over those from the other Departments is not clear. The Annual Report from the Treasury and the Annual Message have occasionally been at cross-purposes.

\footnotetext{
${ }^{10}$ Dewitt, Impeachment and Trial of Andrew Johnson, 193.

${ }^{17}$ Statutes at Large, XXXV, 1027, Section 7.
} 
The Interior Department has been a place for a good deal of friction between President and Secretary over the carrying out of specific acts of Congress. In the case of the McGarrahan Claim, President Grant overruled Secretary Cox so preemptorily, that it was questioned by the newspapers, whether official self-respect did not require the Secretary to resign. An apparent conflict between President Cleveland and Secretary Vilas attracted attention; but in this case, facts and appearances seem to have been contradictory. ${ }^{18}$ There is good reason to believe that in the disputes with which the Land Office has been concerned in more recent years, the President has set the orders of the Secretary of the Interior at naught more often than the public has known.

The distinction is still drawn between the two kinds of acts or duties that a Department Head performs. But the Supreme Court in I866, handed down a very restrictive definition of the field in which - such officer has been deemed to be uncontrollable by the President: "A ministerial duty, the performance of which may, in proper cases, be required of the Head of a Department by judicial process, is one in respect to which nothing is left to discretion. It is a simple definite duty, arising under conditions admitted or proved to exist, and imposed by law." 19 On the other hand, in cases where discretion is involved in acts imposed by statutes, the working theory is that the ultimate discretion is the President's. This doctrine is upheld by the opinions of several Attorneys-General. ${ }^{20}$ There are documentary survivals of the narrower interpretation of the President's authority. Stanton expressed the restrictive view, in his reply to Johnson's charges. ${ }^{21}$ And almost a generation later, John Sherman in an utterance that rings more like an echo than a voice, asserted the doctrine that the President has no more right to control or exercise the powers or functions conferred upon the Department Heads by laws, than they have to control him in the exercise of his duties.

${ }^{18}$ Political Science Quarterly, IV, 452, F. P. Powers, Railroad Indemnity Lands.

${ }^{19} 4$ Wallace, 498, Mississippi v. Johnson.

${ }^{20}$ Opinions of the Attorney-General, VII, 453-482, Cushing; X, 527-539, Bates.

${ }^{21}$ Gorham, Life of Edwin M. Stanton, II, 420.

${ }^{22}$ Sherman, Recollections of Forty Years, I, 449. 
On the other hand, some changes are to the advantage of the Cabinet. The great gain to the Presidency in theory is of necessity modified in practice by the vast expansion of administrative operations, an increase that is signalized not only by the doubling of the number of portfolios, but by great development in Department organization, in which a new era may be distinctly traced from the beginning of the Civil War. The Secretaries themselves have withdrawn from operating the Departments in the sense in which they did during the first sixty or seventy years of the National Government. And the President has ceased from knowledge of the ordinary round of business. To great effect might Washington's direct acquaintance with Department correspondence ${ }^{23}$ be set over against Lincoln's powerlessness to keep abreast of the papers that required his signature. ${ }^{24}$ Notwithstanding the fact that long usage is against interference with ordinary Department business, a forceful Chief Executive would probably assert the right to interfere, if any occasion for doing so came to his knowledge.

The President has acquired new authority over his assistants; but he has become more dependent upon them. The frequency and regularity of Cabinet sessions is a very visible proof. Prior to the Civil War, every President had a practice of his own. In the literature of Lincoln's administration, there are clear traces of the TuesdayFriday rule; but Lincoln was most unmethodical about observing it. Johnson held the semi-weekly consultations with great regularity. And the custom has since been observed without interruption, when the President is at the seat of Government and able to attend to his duties. Without the President, there is no such thing as a Cabinet meeting.

A Cabinet conference is exactly like a conference of a Board of Directors. Ordinarily a few men dominate the discussion; and yet the suggestions of the others are helpful. The nature and scope of Cabinet discussions depend upon the President. General Grant seems to have had a fashion of calling for reports of things done in the different Departments. Many Presidents would despatch such

${ }^{23}$ Writings of Jefferson, VIII, 99.

${ }^{24}$ Welles, Lincoln and Seward, 68, 70. 
matters with individual Secretaries. And Lincoln treated such large affairs as purely Departmental concerns that he called forth a protest from the Senate. Washington's consultations ranged from the great problems of foreign relations to the details of procedure and the fine points of etiquette.

The Cabinet's claims to a right to be consulted depend upon precedent and custom. And these are only beginning to be appreciated as forces in American institutions. The President is not obliged to consult the Cabinet; but he is expected to consult it. Public opinion cannot compel him to do so on specific subjects, because it is not sufficiently well informed of current happenings. The secrecy of the Cabinet is well guarded, despite the enterprise of press agencies. The inside history of President Roosevelt's intervention between Japan and Russia in 1905 is not yet generally known. The Administration was much dispersed at the time, and Mr. Hay, the Secretary of State, was in his last illness. A strong force to compel consultation with individual Secretaries is the standard of official self-respect that attaches to Cabinet office. The rule may be laid down that the President ordinarily consults with the Cabinet on matters of grave public importance, and that only under most extraordinary conditions would he take action affecting the work of a particular Department without conference with the Head of that Department.

The tendency of political science is to speak more disparagingly of the Cabinet's claims than actual practice justifies. An unfortunate legend has grown up that the Cabinet has been ignored in Executive transactions of very great importance. The Louisiana Purchase and the Emancipation Proclamation have become kind of stock examples, although facts to show that the Cabinet was not overlooked are matters of common knowledge. ${ }^{25}$ President Jefferson himself did not know of the Louisiana Purchase, until after the Commissioners had closed with the Emperor's proposal. The lesser project to acquire New Orleans had been previously discussed with his Cabinet, as was the ratification of the treaty afterwards. The Emancipation Proclamation was, in its important aspects, President Lincoln's unassisted act. But everybody knows that the document was

${ }^{25}$ Infra, Administrations of Jefferson and Lincoln. 
read to the Cabinet. And much informal discussion of emancipation had preceded the President's resolution to take the step. There have been real cases of failure to consult the Cabinet. But they are not so imposing as these legendary examples. And they tend to show that the opposite course is the one that is expected. President Polk refrained from consulting his Cabinet about the veto of the River and Harbor Bill of 1846 , because he had made up his mind that he could not sign the bill under any circumstances. ${ }^{*}$. And President Hayes once announced a policy and carried it out, without asking his Cabinet for their views, because he knew beforehand that his course would be disapproved. ${ }^{27}$ General Grant, in his naiveté about government by deliberation, either ignored or misled his Cabinet in the negotiation for the annexation of San Domingo. And Secretary Fish of the State Department would have laid down his office for the affront, had not fears for the welfare of his party constrained him.

Technically the existence of the Cabinet is voluntary with the President. But it has strong sanctions in the body of unwritten law that is growing up. The idea that the Executive should be plural in its deliberations has obtained almost from its establishment. The proposition to attach a Council to the Presidency by Constitutional provision failed in the Federal Convention. But, when the Government had only rounded out its first decade, the dispersed condition of the Executive under President John Adams provoked sharp disapproval, and contributed to the downfall of the Federalist party. Although the collegiate existence of the Cabinet was irregular for nearly three-quarters of a century, it was not often interrupted. Jackson held no Cabinet meetings during the first two years of his presidency; whereat a Congressional lobby from his own section of the country requested him to observe that practice. In the second year of the Civil War, the Cabinet was not sufficiently in evidence to satisfy all parties. And a powerful lobby from the Senate, instigated by Secretary Chase, waited upon the President about the matter. The separateness of the Cabinet from other advisers has been carefully guarded. And the present view of those occasions when out-

20 Polk's Diary, VIII, 7.

${ }^{2}$ Stevens, Sources of the Constitution, 167, Footnote. 
siders meet with it, as happened in the Spanish-American War of $\mathrm{r} 898$, is that the affair is a special consultation, even though it should happen at the time and place of a regular Cabinet meeting. Acting Secretaries have sometimes been summoned, but such is not recent practice. Presidents have resorted to extra-Cabinet counsels with great freedom. Congressional intimacies are a necessity. Madison served Washington for a spokesman in the House of Representatives, as Lodge did Roosevelt in the Senate. Care for the political side of the administration also takes the President outside of the Cabinet, although the Post Office is a manager's portfolio. Amos Kendall and Thurlow Weed are a familiar type of Presidential adviser. The prestige of the official Cabinet has occasionally suffered for the favor shown to men who stood close to the President in informal ways. But "Kitchen Cabinets" are not pleasing to public sentiment. The Cabinet has once been recognized by statute. This occurred in the General Appropriations Act of 1907, where it is called by name in the clause that fixes the salaries of its members.

The American Cabinet is not performing any blind or unsuspected functions. Neither has it been the seat of any great transformations in the nature of the Government. It is not a main-spring or a pivot; but it has shown itself to be an essential attachment. It is so adjusted that the American Executive is plural in deliberation, while it is single in responsibility. 


\section{BIBLIOGRAPHY.}

\section{CONTEMPORARY CORRESPONDENCE AND DIARIES.}

Adams, John. Works with a Life of the Author. Edited by C. F. Adams. Io vols. Boston: $1854-1856$.

Adams, John Quincy. Memoirs, comprising parts of his Diary from 1795 to I848. I2 vols. Philadelphia: 1874-1877.

Ames, Fisher. Works. Selections from Speeches and Correspondence. Edited by Seth Ames. 2 vols. Boston: 1854.

Buchanan Papers. MSS. Library of Historical Society of Pennsylvania.

Buchanan, James. Works. Edited by John Bassett Moore. 12 vols. Philadelphia and London: 1908-rgrr.

Calhoun, J. C. Correspondence. Edited by J. F. Jameson. American Historical Association, Annual Report, 1899, II. Washington: 1900.

Chase Papers. Diary and Correspondence of Salmon P. Chase. American Historical Association. Annual Report for 1902. II. Washington: I903.

Clay, Henry. Works. Edited by Calvin Colton; with an introduction by Thomas B. Reed, 1 and an history of tariff legislation, 1812-1896, by William McKinley. Io vols. New York: 1904.

Clayton Papers. MSS. Library of Congress.

Fillmore, Millard. Papers. Edited by Frank H. Severance. 2 vols. Publications of the Buffalo Historical Society. X, XI. Buffalo: I907.

Gallatin, Albert. Writings. Edited by Henry Adams. 3 vols. Philadelphia: I879.

Garfield. MSS. Letters. Private Possession.

Hamilton, Alexander. Works. Comprising his Correspondence, and his Political and Official Writings, exclusive of the Federalist, Civil and Military. Edited by John C. Hamilton. 7 vols. New York: I851.

Hamilton, Alexander. Works. Edited by Henry Cabot Lodge. 12 vols. New York and London: 1903.

Jackson Papers. MSS. Library of Congress.

Jay, John. Correspondence and Public Papers. Edited by Henry P. Johnson. 4 vols. New York and London: I890-I893.

Jefferson, Thomas. Writings. Edited by H. A. Washington. 9 vols. Washington: $1853-1854$.

Jefferson, Thomas. Writings. Edited by P. L. Ford. Io vols. New York: I892-1899.

Johnson Papers. MSS. Library of Congress. 
Knox Papers. MSS. Library of New England Historic Genealogical Society. Maclay, William. Journal. New York: 1890.

Madison, James. Letters and Other Writings. By order of Congress. 4 vols. New York: 1884.

Madison, James. Papers. Edited by Henry D. Gilpin. 3 vols. Washington: 1840.

Madison, James. Writings. Edited by Gaillard Hunt. 9 vols. New York, etc. : 1900-I9I0.

Monroe, James. Writings. Edited by Stanislaus Murray Hamilton. 7 vols. New York and London: 1898-1903.

Pierce, Franklin. Selected Letters. American Historical Review. X, No. 3.

Polk. Diary and Letters. Lenox Library.

Polk Papers. MSS. Library of Congress.

Van Buren Papers. MSS. Library of Congress.

Washington, George. Writings. Edited by Jared Sparks. I2 vols. Boston: I837.

Washington, George. Writings. Edited by W. C. Ford. I4 vols. New York: I889-1893.

Washington's Letter Books. Library of Congress.

Webster, Daniel. Private Correspondence. Edited by Fletcher Webster. 2 vols. Boston: 1857 .

Webster, Daniel. Letters. Edited by C. H. Van Tyne. New York: 1902. Welles, Gideon. Diary. Atlantic Monthly. 1909-I9Io. CIII, CIV.

\section{AUTOBIOGRAPHIES AND PERSONAL REMINISCENCES.}

Benton, T. H. Thirty Years' View : a History of the Working of the American Government for Thirty Years, from 1820 to 1850 . New York: $1854-1856$.

Blaine, James G. Twenty Years of Congress, from Lincoln to Garfield. With a Review of the Events which led to the Political Revolution of 1860. 2 vols. Norwich, Conn.: 1884

Boutwell, George S. Reminiscences of Sixty Years in Public Affairs. 2 vols. New York: 1902.

Buchanan, James. Mr. Buchanan's Administration on the Eve of the Rebellion. New York: 1866.

Foster, John W. Diplomatic Memoirs. 2 vols. Boston: 1909.

Hoar, George F. Autobiography of Seventy Years. 2 vols. New York: I903.

Kendall, Amos. Autobiography. Edited by William Stickney. Boston: 1872. King, Horatio. Turning on the Light. A Dispassionate Survey of President Buchanan's Administration, from 1860 to its close. Philadelphia: I895. McCulloch, Hugh. Men and Measures of Half a Century. New York: I888. Platt, Thomas Collier. Autobiography. New York: 1910. 
Schofield, Lieutenant-General John M. Forty-Six Years in the Army. New York: 1897.

Seward, F. W. William H. Seward. 3 vols. (I, Autobiography, I83I-1846; II, III, Seward at Washington, I846-1873.) New York: I890.

Sherman, John. Recollections of Forty Years in the House, Senate, and Cabinet. An Autobiography. 2 vols. Chicago: 1896.

Schurz, Carl. Reminiscences. Completed by Frederic Bancroft and William A. Dunning. 3 vols. Chicago: 1907-1908.

Weed, Thurlow. Autobiography. Edited by Harriet A. Weed. (Vol. I.) Memoir of Thurlow Weed by Thurlow Weed Barnes. (Vol. II.) Boston: 1884 .

\section{DOCUMENTARY MATERIALS, MANUALS, ETC.}

Clarke, Matthew St. Clair, and Hall, David A. Legislative and Documentary History of the First Bank in the United States. Washington: 1832 .

Elliot, Jonathan. The Debates of the Several State Conventions on the Adoption of the Federal Constitution. 5 vols. Washington: 1845 .

Lanman, Charles. Biographical Annals of the Civil Government of the United States during its First Century. Washington: 1876.

McKee, T. H. Manual of Congressional Practice. Washington: 1890.

Mosher, R. B. Executive Register of the United States, 1879-1902. Baltimore: 1903 .

Poore, Ben: Perley. The Federal and State Constitutions, Colonial Charters, and other Organic Laws of the United States. 2 vols. Washington: 1877.

Richardson, James D. Messages and Papers of the Presidents. 1780-1897. Io vols. Washington: 1899 .

United States. Annals of Congress. I789-1823.

United States. Congressional Globe. 1833-1873.

United States. Congressional Record. I873.

United States. Executive Journal of the Senate. 1789.

United States. The Impeachment and Trial of Andrew Johnson. 3 vols. Washington: 1868.

United States. Journals of the Senate and House of Representatives. 1789 .

United States. House of Representatives Reports, Thirty-Eighth Congress, First Session. No. 43.

United States. Senate Documents, Twenty Seventh Congress, First Session. United States. Senate Reports, Forty-Sixth Congress, Third Session, No. 837 .

United States. The Statutes at Large of the United States. 1780.

United States. Revised Statutes of the United States. 1878. 
United States Reports. Reports of Cases Argued and Adjudged in the Supreme Court of the United States. New York: 1882-

United States Official Opinions of the Attorneys-General of the United States. Washington: 1852 .

\section{TREATISES, ETC.}

Bagehot, Walter. The English Constitution. New and Revised Edition. Boston: 1873 .

Bryce, James. The American Commonwealth. 2 vols. London and New York: 1888.

Burgess, John W. Political Science and Constitutional Law. 2 vols. Boston and London: 1890.

Fairlie, John A. National Administration of the United States of America. New York and London: 1905.

Finley, John H. and Sanderson. The American Executive. New York: 1908. (The American State Series.)

Foster, John W. A Century of American Diplomacy. Boston: 1900.

Goodnow, Frank J. Comparative Administrative Law. 2 vols. New York and London: 1893 .

Goodnow, Frank J. Politics and Administration. New York: 1900.

Hamilton, Alexander. With Madison and Jay. The Federalist. Edited by

J. C. Hamilton. Philadelphia : I864.

Harrison, Benjamin. This Country of Ours. New York: 1897.

Hart, Albert Bushnell. Practical Essays on Government. New York: 1893.

Hart, Albert Bushnell. The Actual Government. New York: 1903.

Hinsdale, B. A. The American Government. Chicago: I895.

Lalor, John J. Cyclopedia of Political Science, Political Economy, and of the Political History of the United States. 3 vols. Chicago: I88I-I884. Lowell, A. Lawrence. Essays on Government. Boston: I889.

Lowell, A. Lawrence. The Government of England. 2 vols. New York, etc.: 1908.

Stevens, C. Ellis. Sources of the Constitution of the United States. New York: 1894 .

Wilson, Woodrow. Congressional Government. Boston: I885.

BIOGRAPHIES: CONTAINING CORRESPONDENCE AND OTHER SOURCE MATERIAL.

Avary, Myrta Lockett. Recollections of Alexander H. Stephens. New York: I9I0.

Coleman, Mrs. Chapman. The Life of John J. Crittenden. With Selections from his Correspondence and Speeches. Philadelphia: I87I.

Conkling, Alfred R. Life and Letters of Roscoe Conkling. New York: I889. 
Conway, Moncure D. Omitted Chapters of History Disclosed in the Lifeand Papers of Edmund Randolph. New York: 1888.

Curtis, G. T. Life of James Buchanan, Fifteenth President of the United States. 2 vols. New York: 1883.

Curtis, G. T. Daniel Webster. 2 vols. Fourth Edition. New York: 1872. Gorham, George C. Life and Public Services of Edwin M. Stanton. 2 vols. Boston: 1899.

Hamilton, Gail. Biography of James G. Blaine. Norwich, Conn.: I895.

Hamilton, John C. History of the Republic of the United States as Traced in the Writings of Alexander Hamilton and his Contemporaries. 7 vols. Philadelphia, I865.

Howe, M. A. DeWolfe. Life and Letters of George Bancroft. 2 vols. New York: 1908 .

King, C. R. The Life and Correspondence of Rufus King. 6 vols. New York: I894-1900.

Lodge, Henry Cabot. Life and Letters of George Cabot. Boston: 1877.

Nicolay, John G., and Hay, John. Abraham Lincoln. A Memoir. Io vols. New York: I8go.

Pickering, Octavius, and Upham, Charles W. Life of Timothy Pickering. 4 vols. Boston: 1867-1873.

Pierce, Edward L. Memoir and Letters of Charles Sumner. I8II-I874. 4 vols. Boston: 1893 .

Schuckers, J. W. The Life and Public Services of Salmon Portland Chase. New York: 1874.

Seward, Frederick W. Seward at Washington, as Senator and Secretary of State. A memoir of his life with selections from his letters. 1846-1872. 2 vols. New York: r89i.

Steiner, Bernard C. The Life and Correspondence of James McHenry. Cleveland: 1907.

Tarbell, Ida M. The Life of Abraham Lincoln. Drawn from original Sources and containing many speeches, letters, and telegrams hitherto unpublished. 2 vols. New York: 1900.

Tyler, L. G. The Letters and Times of the Tylers. 3 vols. Richmond: I884-I896.

Warden, Robert B. An account of the Private Life and Public Services of Salmon Portland Chase. Cincinnati: 1874.

\section{BIOGRAPHIES AND LIVES.}

Adams, John Quincy, and Charles Francis. Life of John Adams. Two vols. in one. Philadelphia: 1874 .

Adams, John Quincy. Lives of Madison and Monroe. Buffalo, Cincinnati : I850.

Adams, Henry. Life of Albert Gallatin. Philadelphia: 1879. 
Adams, Henry. John Randolph. (American Statesmen Series.) Boston: 1882.

Badeau, Adam. Grant in Peace. Hartford: 1887.

Bancroft, Frederic. The Life of William H. Seward. 2 vols. New York, etc.: 1900.

Buell, Augustus C. History of Andrew Jackson. 2 vols. New York: 1904.

Burton, Theodore E. John Sherman. (American Statesmen, Second Series.) 1906.

Chandler, Zachariah. An outline sketch of his life and public services. By The Detroit Post and Tribune. Detroit: I880.

Dallas, G. M. Life and Writings of Alexander James Dallas. (Philadelphia: 1871.

Davis, Varina Jefferson. Jefferson Davis. A Memoir by his Wife. 2 vols. New York: 1890.

Dix, John Adams. Memoirs. Compiled by his son, Morgan Dix. 2 vols. New York: I883.

Fessenden, Francis. William Pitt Fessenden. 2 vols. Boston and New York: 1907.

Forman, S. E. Thomas Jefferson, Life and Writings. Indianapolis: 1900.

Foulke, W. O. Oliver P. Morton. 2 vols. Indianapolis, etc.: 1899.

Garland, Hamlin. Grant: His Life and Character. New York: 1898.

Gay, Sidney Howard. James Madison. (American Statesmen Series.) Boston: I884.

Hart, Albert Bushnell. Salmon Portland Chase. (American Statesmen Series.) Boston and New York: 1899.

Harvey, Peter. Reminiscences of Daniel Webster. Boston: I877.

Herndon, William H., and Weik, Jesse W. Abraham Lincoln. The True Story of a Great Life. With an Introduction by Horace White. 2 vols. New York: 1896.

Hunt, C. H. Life of Edward Livingston; with introduction by George Bancroft. New York: 1864

Hunt, Gaillard. Life of James Madison. New York: 1902.

Jenkins, John S. Life of Silas Wright. Auburn, Rochester: 1852.

Kennedy, J. P. Life of William Wirt. Two vols. in one. Philadelphia: I860.

Lodge, Henry Cabot. Alexander Hamilton. (American Statesmen Series.) Boston: 1882 .

Lodge, Henry Cabot. Daniel Webster. (American Statesmen Series.) Boston: 1883 .

Lodge, Henry Cabot. George Washington. (American Statesmen Series.) 2 vols. Boston: 1889 .

Lothrop, Thornton K. William Henry Seward. (American Statesmen Series.) Boston, etc: 1897.

McLaughlin, A. C. Lewis Cass. (American Statesmen Series.) Boston. etc.: 1891 . 
Marshall, John. Life of George Washington. 5 vols. London: 1806-1807. Morrow, Josiah. Life and Speeches of Thomas Corwin. Cincinnati: 1896. Morse, John T. Abraham Lincoln. (American Statesmen Series.) 2 vols. Boston, etc. : 1896.

Morse, John T. John Quincy Adams. (American Statesmen Series.) Boston: 1882.

Morse, John T. Thomas Jefferson. (American Statesmen Series.) Boston: I883.

Parton, James. Life of Andrew Jackson. 3 vols. New York: 1860.

Parton, James. Thomas Jefferson. Boston: 1874.

Randall, Henry S. Thomas Jefferson. 3 vols. New York: 1858.

Randolph, Sarah N. The Domestic Life of Thomas Jefferson. New York: I87.

Raymond, Henry J. The Life and Public Services of Abraham Lincoln, Sixteenth President of the United States, together with his State Papers. New York: 1865.

Roosevelt, Theodore. Thomas H. Benton. (American Statesmen Series.) Boston: 1886.

Schurz, Carl. Henry Clay. (American Statesmen Series.) 2 vols. Boston: I890.

Shepard, E. M. Martin Van Buren. (American Statesmen Series.) New York: I888.

Stanwood, Edward. James G. Blaine. (American Statesmen, Second Series.) Boston, etc. : 1905.

Stevens, John Austin. Albert Gallatin. (American Statesmen Series.) Boston: 1883.

Sumner, W. G. Andrew Jackson as a Public Man. (American Statesmen Series.) Boston, etc.: 1882.

Tyler, Samuel. Memoir of Roger Brooke Taney, LL. D. Baltimore: 1872.

Von Holst, H. John C. Calhoun. (American Statesmen Series.) Boston: 1882.

Wheaton, Henry. William Pinkney. Some Account of Life, Writings, and Speeches. New York: 1826.

Wise, H. A. Seven Decades of the Union. A Memoir of John Tyler. Richmond: 1881 .

\section{HISTORIES : GENERAL WORKS.}

Adams, Henry. History of the United States. I80r-1817. 9 vols. New York: 1891. (Extensive notice of the Cabinet.)

Hildreth, Richard. The History of the United States of America. 6 vols. New York: 1856.

McMaster, J. B. A History of the People of the United States. 5 vols. New York: $1883-1905$. 
Rhodes, James Ford. History of the United States, 1850-1877. 7 vols. New York and London: 1892-1906. (Very valuable for study of the Pierce and Buchanan Cabinets.)

Schouler, James. History of the United States of America under the Constitution. 6 vols. Revised edition. New York: I880-1899.

Von Holst, H. The Constitutional and Political History of the United States. 6 vols. Chicago: $1877-1889$.

\section{SPECIAL HISTORIES, MONOGRAPHS, AND ARTICLES.}

Alexander, De Alva Stanwood. A Political History of the State of New York. 3 vols. New York: 1906.

Ames, Herman V. The Proposed Amendments to the Constitution of the United States during the First Century of its History. American Historical Association. Annual Report for I896. II. Washington: 1897. Catterall, R. C. H. The Second Bank of the United States. Chicago: 1903. Dallinger, F. W. Nominations for Elective Office. (Harvard Historical Monographs.) Boston: I897.

Davis, Jefferson. The Rise and Fall of the Confederate Government. 2 vols. New York: I88I.

Dewitt, David Miller. The Impeachment and Trial of Andrew Johnson. New York: I903.

Dunning, William A. Essays on the Civil War and Reconstruction. The Macmillan Company: 1898.

Fish, Carl R. The Civil Service and the Patronage. New York: 1905.

Follet, Miss M. The Speaker. New York: 1896.

Gibbs, George. Administrations of Washington and Adams, or Memoirs of the Administrations of Washington and John Adams. Edited from the Papers of Oliver Wolcott, Secretary of the Treasury. New York: 1846. Guggenheimer, J. C. The Development of the Executive Departments, 17751789. In Essays in the Constitutional History of the United States. Edited by J. Franklin Jameson. Boston, etc.: I889.

Hunt, Gaillard. The Department of State: History and Functions. Washington: 1893 .

McConachie, Lauros G. Congressional Committees. New York: 1898.

Mason, Edward Campbell. The Veto Power: Its Origin, Development, and Function in the Government of the United States. I789-1889. Edited by Albert Bushnell Hart. Harvard Historical Monograph. No. I. Boston: 1890 .

Pollard, Edward A. Life of Jefferson Davis in Secret History of the Southern Confederacy. Philadelphia, etc.: I869.

Salmon, Lucy M. History of the Appointing Power of the President. Papers of the American Historical Association. I. No. 5. New York, etc.: I886.

Stanwood, Edward. A History of the Presidency. Boston, etc.: 1898. 
Stanwood, Edward. History of Presidential Elections. Fourth Edition. Revised. Boston: I892.

Stephens, Alexander H. A Constitutional View of the late War between the States. Two vols. in one. Philadelphia: I868-1870.

Tyler, L. G. Parties and Patronage in the United States. New York, etc.: I89I.

Wood, John. The History of the Administration of John Adams. New York: 1802.

American Political Science Association. Proceedings. II, I26-I48, Mary L. Hinsdale, The Cabinet and Congress: an Historical Inquiry.

American Political Science Review, III, 329-347. Henry Barrett Learned, Historical Significance of the term "Cabinet" in England and the United States.

American Historical Review, X, 565. Henry Barrett Learned, Origin of Title "Superintendent of Finance."

Yale Review, XV, I60-194. Henry Barrett Learned, Origin and Creation of the President's Cabinet.

\section{NEWSPAPERS AND MAGAZINE ARTICLES.}

Richmond Enquirer. Richmond: 1804, etc.

Globe, Washington: 1830-1845.

Madisonian, Washington: $1841-1842$.

The Nation. New York: I866-

National Intelligencer. Washington: I800-1869.

Niles Register. Baltimore: I8I I-I849.

New York Tribune. New York: 184I-

Union. Washington: $1845-1857$.

United States Telegraph. Washington: $1828-1830$.

The Atlantic Monthly. Boston. XXVI, 463. Wilson, Henry, Black and Stanton. LXXVI, I62. Cox, Jacob D., How Judge Hoar Ceased to be Attorney-General. (Very important article in the present state of material.)

The Century. New York. XXV, 34I, 799. Dawes, Henry L., Garfield and Conkling.

The Galaxy: X, Iog-I19. Gideon Welles, The Facts of the Abandonment of Gosport Navy Yard. Mr. Welles in Answer to Mr. Weed. Ibid., 613-637. Gideon Welles, Fort Sumpter. Facts in Relation to the Expedition Ordered by the Administration of President Lincoln for the Relief of the Garrison in Fort Sumpter. Ibid., 474-482. Horatio King, James Buchanan. XI, 257-276. J. S. Black, Mr. Black to Mr. Wilson. XIII, 52I532; 663-673. Gideon Welles, Lincoln and Johnson. (Two Papers to show that Johnson's Plan of Reconstruction was substantially the same as Lincoln's.)

The North American Review. Boston: New York. CXXIX. 4 Nos. The Diary of a Public Man. 


\section{SPEECHES AND PAMPHLETS.}

Adams. The Address of Charles Francis Adams, of Massachusetts, on the life, character, and services of William H. Seward. Delivered by invitation of the Legislature of the State of New York, in Albany, April I8, 1873. New York: 1873.

Adams, John, and Cunningham, William. Correspondence between the Hon. John Adams, late President of the United States, and the late William Cunningham, Esq., beginning in 1803 , and ending in 1812. Boston: 1823 . Armstrong, Kosciuszko. Review of T. L. McKenney's Narrative of the causes which in 1814, led to General Armstrong's Resignation of the War Office. New York: 1846.

Lincoln, Abraham. Complete Works, Comprising his speeches, state papers, and miscellaneous writings. Edited by John G. Nicolay and John Hay. 2 vols. New York: 1894.

Pickering, Timothy. Review of the Correspondence between the Hon. John Adams and William Cunningham, Esq. Salem: 1824 .

Quincy, Josiah. Speeches Delivered in the Congress of the United States. Edited by his son Edmund Quincy. Boston: 1874 .

Randolph, Edmund. Vindication of Mr. Randolph's Resignation. Philadelphia: 1795 .

\section{MISCELLANEOUS.}

Blaine, Mrs. James G. Letters. Edited by Harriet S. Blaine Beale. 2 vols. New York: 1908.

Carpenter, F. B. Six Months at the White House with Abraham Lincoln. New York: 1865.

Dana, C. A. Recollections of the Civil War. With the Leaders at Washington and in the Field in the Sixties. New York: 1898.

Chittenden, L. E. Recollections of President Lincoln and his Administration. New York: 189r.

Chittenden, L. E. Personal Reminiscences, I840-1890, including some not hitherto published of Lincoln and the War. New York: 1893.

Crook, William H. Through Five Administrations. Edited by Margarita Spalding Gerry. New York: 19ro.

Field, Maunsell B. Memories of Many Men and Some Women. New York: 1874 .

Forney, John W. Anecdotes of Public Men., 2 vols. New York: 1873 and I88I. Gilmore, James R. Personal Recollections of Abraham Lincoln and the Civil War. Boston: 1898.

Gobright, L. A. Recollections of Men and Things at Washington, during the third of a Century. Philadelphia: 1869.

Hamilton, James A. Reminiscences. Men and Events at Home and Abroad, during three quarters of a century. New York: 1869. 
Lamon, Ward H. Recollections of Abraham Lincoln, I847-1865. I895.

McClure, A. K. Abraham Lincoln and Men of War Times. Some personal recollections of War and Politics during the Lincoln Administration. Philadelphia : 1892.

Piatt, Don. Memoirs of the Men who saved the Union. New York, etc. : I887. Poore, Ben: Perley. Perley's Reminiscences of Sixty Years in the National Metropolis. 2 vols. Philadelphia: I886.

Riddle, A. G. Recollections of War Times. Reminiscences of men and events in Washington. I860-I865. New York: 1895.

Rice, Allen Thorndike. Reminiscences of Abraham Lincoln. By distinguished men of his time. Collected and edited by Allen Thorndike Rice. The North American Review. New York: I888.

Rothschild, Alonzo. Lincoln, Master of Men. Boston: 1906.

Sargent, Nathan. Public Men and Events. 2 vols. Philadelphia: 1875.

Sherman Letters, The. Correspondence between General and Senator Sherman from 1837 to 1891 . Edited by Rachel Sherman Thorndike. New York: 1894 .

Smith, Margaret Bayard. The First Forty Years of Washington Society. Letters. Edited by Gaillard Hunt. New York: 1908.

Welles, Gideon. Lincoln and Seward. New York: 1874. 


\section{INDEX.}

Adams, John, retains Washington's cabinet, $3 \mathrm{I}$; calls on cabinet for opinions on French relations, 3I, 32 ; opposed to Hamilton, $3 \mathrm{I}$; and his cabinet, $3 \mathbf{I}, 32$; absences from Washington, 32 ; opinion of Hamilton, 32; his controversy over the major-generals, 33, 34; and his secretaries, $34,35,36$.

Adams, J. Q., Secretary of State, 66; coalition cabinet of, 73, 74; cabinet relations under, 75 ; resignations in his cabinet, 76,77 .

Ad interim appointments, 203; act relative thereto, 203.

Agriculture, Department of, established, 248; its history, 248 ; organization, 248 ; report of the Secretary, 308.

Alger, Russell A., Secretary of War, 263; resigns, 265.

Allison, William B., and Secretaryship of the Treasury, 234.

Ames, Fisher, urges co-operation of Federalists in Congress, 32.

Akerman, Amos T., Attorney-General, 212; character, 212.

Armstrong, John, Secretary of War, 55; character, 55 ; resigns, 57.

Arthur, Chester A., accepts resignation of Garfield's cabinet, 24I ; appointments, 24I, 242, 243; ability of his cabinet, 242.

Assistant Attorney-General, 217.

Assistant-Secretary, influence of, 263. Attorney-General, office created, 8; duties, 8 ; not consulted by the
President at first, IO, II ; consulted on Bank Act (I79I), II; gives opinion on constitutionality of Apportionment Act (1792), I2; President said should be consulted, I2; position in cabinet strengthened by Genet mission, I4; Bradford succeeds Randolph as, 25; proposals for, 27 , note; absent from seat of government, attending to private practice, 67; fixed residence, 67; Butler, non-resident, IOI; ranks with the Secretaries, I49; heads Department of Justice, 216; duties, 216,217 ; in the Confederate Government, 217 , note.

Bacon, Robert, Secretary of State, 275.

Badger, George, Secretary of the Navy, I07; resigns, II3.

Ballinger, Richard A., Secretary of the Interior, 280; controversy over, 280, 28I ; resigns, $28 \mathrm{I}$.

Bancroft, George, on Van Buren's policy towards the secretaries, 99, IOO; Secretary of the Navy, I29; why appointed, I30; resigns, I33; efficiency, 133; Minister to England, I33.

Barbour, James, Secretary of War, 74; Minister to England, 76.

Barry, William T., Postmaster-General, 83 ; first Postmaster-General of cabinet rank, 83 .

Bates, Edward, in Lincoln's cabinet, I7I, I72, I74; resigns, I87. 
Bayard, Thomas F., Secretary of State, 247.

Bell, John, Secretary of War, I06; resigns, II3.

Belknap, W. W., Secretary of War, 210; impeached, 214, 215; resigns, 215.

Berrien, John M., Attorney-General, 82.

Bibb, George M., Secretary of the Treasury, 122.

Bissell, Wilson S., Postmaster-General, 259.

Black, Jeremiah S., Attorney-General, 162; Secretary of State, I65.

Blaine, James G., and Hayes, 22I, 225 ; Secretary of State, 233; characterized by Garfield, 235, 236; retires, 242; Secretary of State under Harrison, 253, 254, 255; resigns, 255.

Blair, Frank P., Jackson and, 85; Johnson's adviser, 192.

Blair, Montgomery, PostmasterGeneral, 174; resigns, 187, 188.

Bliss, Cornelius N., Secretary of the Interior, 264; retires, 265.

Bonaparte, Charles J., Secretary of the Navy, 271, 272; Attorney-General, 273.

Borie, Adolph E., in Grant's cabinet, 210; resigns, 210.

Boutwell, Secretary of the Treasury, 209; enters Senate, 213.

Bradford, William, succeeds E. Randolph as Attorney-General, 25; dies, 26.

Branch, John, Secretary of the Navy, 82.

Brewster, Benj. H., Attorney-General, 242.

Brown, Aaron V., Postmaster-General, 162; dies, 162.
Browning, O. H., Secretary of the Interior, 193.

Buchanan, James, declines AttorneyGeneralship, IOI ; Secretary of State, I29; cabinet appointments, 161,162 ; and his cabinet, 163,164 , I65, 167.

Butler, B. F., Attorney-General, 94; resigns, IOI ; declines Secretaryship of .War, 129.

Cabinet, origin of, I; executive departments in Continental Congress and, 2; under Washington, 7; Washington's first, 9; consulted by the President, 9, IO, II; and Bank Act (I79I), II; meeting of (1791), I2; on constitutionality of Apportionment Act (1792), I2 ; consulted by President on Excise Law (1792), 12; and address to Congress (1792), I3; influenced by Virginia executive council, I3. meetings under Washington, I3; effect of Genet mission on, 14; and French Neutrality, I4; "assembled consultation" begins (1793), I4; naming of, 15 ; separation from other advisers, 16 ; different parties in, 22, 23; conflict in, 23; reorganization of and Jay's Treaty, 26; Washington on divergent views in, 26 ; becomes entirely Federalist, 26; President Adams and, 37; relation with President discussed, 37; unanimity of Jefferson's, 43; meetings under Jefferson, 43; and Louisiana purchase, 46; relations discussed by Jefferson, 52, 53; quarrels, 55, 56, 57 ; double appointments in, 58; government by under Jefferson and Madison, Quincy's remarks on, 59, 60; geographical represen- 
tation in, 65; Monroe's attitude towards, 65 ; character under Monroe, 67 ; rivalry for the Presidency in, 68; and Congress, 68; meetings under Monroe, 69; and Jackson, 69; and Missouri Compromise, 69; goes with President to Capitol on last night of a session, 69; relations under Monroe, 70; coalition cabinet of J. Q. Adams, 73, 74; relations under J. Q. Adams, 75; character of Adams', 75; and appointment of the General-in-chief ( 1828$), 75,76$; speeches by members of, 76 ; the "travelling Cabinet," 76; tenure in discussed, 77 ; new features under Jackson, 8I ; Jackson's appointments, 8r, 82, 83; Congress and Jackson's appointments for, 84 ; character of Jackson's 84 ; the "Kitchen," 84,85 , 86 ; meetings discontinued under Jackson, 86; attitude of Jackson to, 88, 89; Jackson's second, 89; removal of the deposits and Jackson's, 90,91 ; views of members on the removal, $9 \mathrm{I}$; reconstructed by Jackson, 9I ; character of Jackson's last, 94; meetings under Van Buren, 99; Van Buren's characterized, I0I, I02; Tyler's relation with his, II2, II3; must change with President, I27; and division among Democrats, I27; character of Polk's, I30; meetings under Polk, 132; originates legislation, 133; formation of Taylor's, I40, I4I ; character of Taylor's I4I ; the Galphin Claim and Taylor's, r43; resignation of Taylor's, I47; and the whigs, I49; salaries raised (I853), I49; character under Pierce, I55; and the Kansas-Nebraska Bill, 156, 157; polls of, 157 ; after Lincoln's election, I62, 163; reconstruction (1860), 163, 164 , 165; and Buchanan, 164, 166, 167; second reconstruction of Buchanan's, 167 ; regency of under $\mathrm{Bu}$ chanan, 168 ; formation of Lincoln's, 171, 172, 173, 174; relations within Lincoln's, 175; Lincoln and, I79; Chase's views, I80; Senate criticizes Lincoln's, I80, I8I ; Lincoln and, I8I; Senate's attitude discussed, 182; and the Emancipation Proclamation, 186; Tenure of Office Act and, 194, 195, 196, 197; Presidential and members of, 202, 203; ad interim appointments, 203; act relative thereto, 203; Tenure of Office Act amended, 203, 204; reappointments of, 204; Grant's characterized, 207; his appointments, 207, 208; double State representation in, 209, 210; Grant and, 2II; low ebb of Grant's, 213; relations within Harrison's, 254; Harrison's Cabinet and Chile, 254; and McKinley's assassination, 265 ; under Roosevelt, 269; activity of Roosevelt's, 271; The Nation on, 272; and newspapers, 272, 273; salaries of members raised, 274 ; political relations of, 283,284 ; and the South, 284; and the opposition, 284 ; changes of the, 284,285 ; and the President, 285; and geographical requirements, 286 ; precedence of state in, 286 ; double representation of states in, 286, 288, 289, 290, 291 ; the West and, 287 ; balance between North and South in, 287, 288; precedence of portfolios in, 288 ; President and cabinet members from the same state, 289 ; foreign missions and, 289; sectionalism and, 289, 290; and the North- 
west, 290; and New York, 290; and Pacific coast, 290; South and West and, 290; rule against double representation relaxed, 290; 29I ; political factions and, 29I, 292; coalition cabinet, 292 ; membership in the Senate and, 292, 293 and note, 294; presidential aspirants excluded from, 294; and unsuccessful candidates for the Presidency, 294, 295; previous status of members of, 295, 296; Congressional committees as trainingschool for members, 296; promotion of assistants, 296, 297; transfer of members, 297; promotion discussed, 297, 298; state governments as training-schools for cabinet members, 298; qualification for, 298; membership in and party service, 298, 299; administrative ability and membership in, 299; cabinet members not in Congress, $30 I$; communications from members of to Congress, 302 ; privilege of debate, 302, 303; Pendleton's resolution, 302,303 ; and the Confederate Congress, 303, 304; informal relations with Congress, 304, 305; social relations with Congressmen, Mrs. Jefferson Davis on, 305; admitted to halls and floors of Congress, 305; reports, 307 ; sends drafts of bills to Congress, 308 ; objected to, 308 ; Senate's resolution against, 309; and appropriations, 309; and Tariff bills, 3ro; and administrative influ. ence, 3ro; and Mint and Coinage Act (1873), 3II; relative influence of, 3I2; not like European ministries, 3I4; subordination to the President, 317 ; removals, $3 I 7$, 318 , confirmation by the Senate,
3I9; control by the President, 320, $32 \mathrm{I}$; double character of members, 32I, 322; Jackson on control of, 323 ; Supreme Court and Presidential control of, 324 ; expansion of duties, 325 ; dependence of President on, 325; weekly meetings of, 325 ; like a board of directors, 325 ; President expected to consult, 326 ; secrecy, 326; not ignored, 326, 327 ; outsiders seldom meet with, 327 , 328.

Cabot, George, declines secretaryship of the Navy, 34; on relations of President with cabinet, 37.

Calhoun, John C., Secretary of War, 66, 67; Secretary of State, 122.

California, McKenna, first member in a cabinet from, 264.

Cameron Don, Secretary of War, 2 I5.

Cameron, Simon, Secretary of War, I74; superseded by Stanton, I77; Minister to Russia, I78.

Campbell, George W., Secretary of the Treasury, 54, 55; resigns, 58. Campbell, James, Postmaster-General, 153 .

Carlisle, John G., Secretary of the Treasury, 259.

Carrington, Edward, proposed for Secretary of War, 27, note.

Cass, Lewis, Buchanan's opinion of, I6I ; Secretary of State, I6I ; resigns, I64.

Chandler, William E., Secretary of the Navy, 242.

Chandler, Zachariah, Secretary of the Interior, 214 .

Chase, Salmon P., and Lincoln's cabinet, 180 ; resigns, I8I, I82 ; resumes his place, I82; and Lincoln, I82, I83, I84, I85; resigns, I84; Chief-Justice, 185 . 
Chief Justice, in President's Council, 4; consulted by the President, Io, II.

Chilian relations, Harrison's cabinet and, 254, 255.

Civil Service Reform, in Grant's administration, 212; and Hayes' Cabinet, 226, 227.

Clay, Henry, Secretary of State, 73; appointment criticized, 74 ; loyal to Adams, 76; and Harrison's appointments, 105, 106; and Webster, 147.

Clayton, John M., Secretary of State, 139, 140.

Cleveland, Grover, and double-representation, 247; his cabinet, 247; and his cabinet, 249; does not recall old cabinet in second administration, 259; appointments in second administration, 259, 260.

Clifford, Nathan, Attorney-General, I34; resigns, I34.

Cobb, Howell, Secretary of the Treasury, I6I ; resigns, I63.

Coleman, Norman J., Secretary of Agriculture, 248.

Collamer, Jacob, Postmaster-General, 140.

Colonial governments, division of powers, I2.

Commerce and Labor, Department of established, 269, 270; duties, 270 ; and other departments, 270 ; first Secretary, 270; report of the Secretary, 308.

Confederation, the, expecutive government in, 3.

Congress, Jackson's cabinet appointments and, 84.

Conkling, Roscoe, and Hayes' appointments, 22I, 225; and Secretaryship of the Treasury, 234.
Constitutional Convention (1787), discusses privy council, $3,4,5,6.7$. Continental Congress, executive departments of, 2 ; created, 2 ; under the Confederation, 3 .

Cortelyou, George B., Secretary of Commerce and Labor, 270; Chairman Republican National Committee, 270; Postmaster-General, 27I; Secretary of the Treasury, 273.

Corwin, Thomas, Secretary of the Treasury, 148.

Council, in colonial government, I-2; in Constitutional Convention (I787), 3, 4 .

Council of State, resolution for in Constitutional Convention, 4, 5; rejected, 5; new resolution for adopted, 5; Mason's motion for (I787), 5, 6 .

Crawford, George W., Secretary of War, I40.

Crawford, William H., Secretary of War, 58, 59; Secretary of the Treasury, 66, and note.

Crittenden, John J., Attorney-General, I06; resigns, II3; again appointed, 148.

Crowninshield, Benj., Secretary of the Navy, 58.

Curtis, B. R., declines Attorney-Generalship, 201.

Cushing, Caleb, nominated Secretary of the Treasury, IIg; rejected by Senate, II9; in Pierce's cabinet, I54, 155 .

Dallas, A. J., preferred by Madison for Secretary of the Treasury, 55; Secretary of the Treasury, 58; also Secretary of War, 58. 
Dana, Francis, named by Adams as Commissioner to France, 33; declines, 33 .

Davie, William R., commissioner to France, 34 .

Davis, Jefferson, Secretary of War, I54; his influence, I57.

Day, William R., Assistant-Secretary of State, 263; Secretary of State, 264; Associate-Justice, 264.

Dearborn, Henry, Secretary of War, $4 \mathrm{r}$.

Delano, Columbus, Secretary of the Interior, 213; retires, 214.

Democrats, division of affects Polk's cabinet, I27, I28; Jackson's views, I28.

Dennison, William A., PostmasterGeneral, I88; resigns, 192.

Departments, in Revolutionary government, 2 ; under the Confederation, 3 ; heads of responsible for, 4; President and, 5; Washington and heads of, 7 ; established, 8.

Deposits, Jackson's cabinet and the removal of the, 90, 9I; Jackson addresses his cabinet on, 91, 92; accomplished, 92; Congress and, 92.

Devens, Charles, Attorney-General, 224; discussed, 223, 224.

Dexter, Samuel, Secretary of War, 36 ; acts as Secretary of State, 36.

Dickerson, Mahlon, Secretary of the Navy, 94.

Dickinson, Don M., Postmaster-General, 248.

Dickinson, Jacob M., Secretary of War, 279; retires, $28 \mathrm{I}$.

Dix, John A., offered Secretaryship of State, I54; Secretary of Treasury, 167.

Dobbin, James C., Secretary of the Navy, I54.
Domestic Affairs, Secretary of in President's Council, 4.

Duane, William J., Secretary of the Treasury, 9I; and removal of the deposits, 9I ; dismissed, 9r.

Eaton, John H., Secretary of War, 81 ; resigns, $87,88$.

Ellsworth, Oliver, on President's council (I787), 4; commissioner to France, 34 .

Elkins, Stephen B., Secretary of War, 255.

Emancipation Proclamation, Lincoln's cabinet and, I86, 326, 327.

Endicott, William C., Secretary of War, 247.

England, Treaty with, 46.

Eustis, William, Secretary of War, 52.

Evarts, William M., Attorney-General, 20I.

Everett, Edward, Secretary of State, I48.

Ewing, Thomas, Secretary of the Treasury, I06; resigns, II3; his views, II4, II5; proposed for Postmaster-General, I40; Secretary of the Interior, I40; Johnson's adviser, I92.

Fairchild, Charles S., Secretary of the Treasury, 248.

Fessenden, William, Secretary of the Treasury, I85; returns to Senate, I88.

Fillmore, Millard, appointments, I47, I48; and Harrison's cabinet, 147, I48.

Finance, superintendency of created (178I), 2; under the Confederation, 3 ; secretary of in President's Council, 5 .

Fish, Hamilton, Secretary of State, 209. 
Fisher, Walter L., Secretary of the Interior, 28I.

Floyd, John B., Secretary of War, 162, I63, I64; resigns, 165, I66.

Folger, Charles J., and Secretaryship of the Treasury, 233, 234; Secretary of the Treasury, 24I, 242; death of, 242.

Foreign Affairs, secretaryship created (I78I), 2; under the Confederation, 3 ; in President's Council, 4; Department of established (I789), 8 ; name changed, 8.

Forsyth, John, Secretary of State, 94. Forward, Walter H., Secretary of the Treasury, II8; resigns, II9.

Foster, Charles, Secretary of the Treasury, 255.

Foster, John W., Secretary of State, 255.

France, relations with, 34 .

Francis, David R., Secretary of the Interior, 260 .

Franklin, B., on President's council, 6.

Frelinghuysen, Frederick T., Secretary of State, 242.

French ministry, Revolutionary officers of state like, 2.

Gage, Lyman J., Secretary of the Treasury, 263; his principles, 263; retires, 269.

Gallatin, Albert, Secretary of the Treasury, 4I ; disliked by Federalists, $4 \mathrm{I}$; proposals for cabinet meetings, 43; position of, 44, 45; transfer to State Dartment opposed, 5I ; minister to Russia, 54 . Galphin Claim, Taylor's cabinet and, I43.

Garfield, James A., and party factions, 23I, 232; demands on him,
232; his plan for appointments, 232; his appointments, 233, 234, 235; and his Secretaries, 235.

Garfield, James Rudolph, Secretary of the Interior, 274.

Garland, Augustus H., AttorneyGeneral, 247.

Gary, James A., Postmaster-General, 264 ; resigns, 264.

Genet, mission of and cabinet, $\mathrm{I} 4$. Gerry, Elbridge, selected by Adams as commissioner to France (1797); not approved by cabinet, 33 ; appointed, 33.

Gilmer, Thomas W., appointed Secretary of the Navy, I20; killed, I2I.

Gilpin, Henry D., Attorney-General, IOI.

Goff, Nathan, Secretary of the Navy, 227.

Granger, Francis, Postmaster-General, I07; resigns, II3.

Granger, Gideon, Postmaster-General, 4I.

Grant, U. S., Secretary of War ad interim, I97; cabinet appointments, 207, 208, 209, 210; and his cabinet, 2II, 2I2, and the McGarrahan claim, 2II ; and the politicians, 2I3, 215,216 ; reappoints his first cabinet, 213; his mediocre cabinet, 213; cabinet changes, 2I4; scandals, 2I4, 215.

Green, Duff, Jackson and, 85.

Gresham, Walter Q., PostmasterGeneral, 242; Secretary of the Treasury, 242; resigns, 243; Secretary of State, 259; dies, 260.

Grundy, Felix, Attorney-General, IOI.

Guthrie, James, Secretary of the Treasury, I54. 
Hale, Eugene, 214; tendered Postmaster-Generalship, 214; declines, 214.

Hamilton, Alexander, advises following French practice with heads of department, 2 ; resolution for appointment of chief officers by President (1787), 6; Secretary of the Treasury, 9; on English and American executive and council, I9; on the head of the Treasury, 19, 20 ; functions assumed as secretary of the Treasury, 20, 2I ; criticized, 22; opposes Jefferson, 23; retires from Washington's cabinet, 25; on relation of the President with his cabinet, 37.

Hamilton, Paul, Secretary of the Navy, 52.

Harlan, James, Secretary of the Interior, I9I ; resigns, I92; in Senate, I93.

Harmon, Judson, Attorney-General, 260.

Harrison, Benj., appointments, 253, 254; relations within his cabinet, 254; and Blaine, 254, 255; cabinet changes, 255.

Harrison, William Henry, his views on cabinet appointments, I05; his appointments, 105, 106, 107; death, I07.

Hatton, Frank, Postmaster-General, 242, 243.

Hay, John, Secretary of State, 264; death, 272.

Hayes, Rutherford B., cabinet draws upon independents, 22I; fails to represent factions, 22I ; cabinet appointments, 222, 223, 224; Senate and, 224, 225; changes in his cabinet, 227 .

Henshaw, David, Secretary of the Navy, I20; unseated by the Senate, I20.
Herbert, Hilary, Secretary of the Navy, 259.

Howe, Timothy O., Postmaster-General, 242 ; retires, 242.

Hill, Isaac, Jackson and, 85.

Hitchcock, Ethan A., Secretary of the Interior, 265; retires, 273.

Hitchcock, Frank H., PostmasterGeneral, 280.

Holt, Joseph, Postmaster-General, I62; on Cass' resignation, I64; Acting-Secretary of War, I66; Secretary of War, 167, I68; declines Attorney-Generalship, 187.

Howard, John E., proposed as Secretary of War, 27, note.

Hunt, William H., Secretary of the Navy, 235; retires, 242.

Impeachment, articles of against President Johnson, I99, 200.

Ingham, Samuel D., Secretary of the Treasury, 82.

Innes, Colonel, proposed for Attorney-General, 27, note.

Insular Affairs, War Department and, 265 .

Interior, Department of established (1849), I34; previous history of, I35; its scope, I35; relations with the President, 324.

Irving, Washington, declines Secretaryship of the Navy, 100, ror.

Jackson, Andrew, and J. Q. Adams, 74; his cabinet appointments, 8I, 82,83 ; discontinues cabinet meetings, 86; quarrels of his administration, 87,88 ; resignations in his cabinet, 88; attitude towards the cabinet, 88,89 ; second cabinet, 89 ; new cabinet appointments by, 94; character of his last cabinet, 94; discusses Polk's cabinet appointments, I28. 
James, Thomas L., Postmaster-General, 234; retires, 242.

Jefferson, Thomas, Secretary of State, 9; opposes Hamilton, 23; position in Washington's cabinet, 24 ; proposed successors to the Secretary of State, 24 , note; first cabinet appointments, $4 \mathrm{I}$; harmony in his cabinet, 43 ; takes cabinet's advice, 46; discusses cabinet relations, 52, 53 .

Jewell, Marshall, Postmaster-General, 2I4.

Johnson, Andrew, retains Lincoln's cabinet, I9I ; reconstruction of his cabinet, I92; Seward's views of, 192, 193; new appointments, I93; Senate and, I98; impeachment of, I99, 200.

Johnson, Cave, Postmaster-General, I 30.

Johnson, Reverdy, Attorney-General, I40.

Jones, William, Secretary of the Navy, 54; resigns, 58.

Justice, Department of, established, 216.

Kansas-Nebraska Bill, Pierce's cabinet and, $156,157$.

Kendall, Amos, influences Jackson, 85 ; Postmaster-General, 94; resigns, IOI.

Key, David M., Postmaster-General, 223; retires, 227.

King, Horatio, Postmaster-General, I68.

Kirkwood, Samuel J., Secretary of the Interior, 235; retires, 242.

“Kitchen Cabinet," Jackson's, 84, 85, 86; Tyler's, II5.

Knox, Henry, Secretary of War, 9; retires from Washington's cabinet, 25.
Knox, Philander C., succeeds Griggs as Attorney-General, 265; enters Senate, 270; Secretary of State, 279; legality of his appointment questioned, 279.

Lamar, Lucius Q. C., Secretary of the Interior, 247; Associate Judge, 248.

Lamont, Daniel S., Secretary of War, 259.

Lawrence, Abbott, proposed for Secretary of the Navy, I40.

Lee, Charles, Attorney-General, 26; Circuit-Judge, 36 ; on double character of the Secretary of State, 322.

Legaré, Hugh, S., Attorney-General, II8; Secretary of State ad interim, I20.

Lewis, W. B., Jackson and, 85.

Lincoln, Abraham, formation of his cabinet, I7I, I72 ; cabinet appointments, I72, I73, I74; and the South, I73; appointments confirmed, I75; relations in his cabinet, 175 ; on Seward's proposals, I76; his independence, I86; rebukes cabinet, I86; and slave indemnity, I86, I87; reconstruction of his cabinet, 187 , I88.

Lincoln, Levi, Attorney-General, 4I ; Secretary of State ad interim, 42. Lincoln, Robert T., Secretary of War, 233.

Loeb Letter, the, on cabinet and newspapers, 272, 273.

Long, John D., Secretary of the Navy, 263; retires, 269.

Louisiana Purchase, Jefferson's cabinet and, 46, 326, 327 .

McClelland, Robert, Secretary of the Interior, 154 . 
McCrary, George W., Secretary of War, 224; discussed, 223, 224; Circuit-Judge, 227.

McCulloch, Hugh, Secretary of the Treasury, I88, 243.

McGarrahan Claim, 2II; Grant and, 2II, 212.

McHenry, James, Secretary of War, 26.

McKenna, Joseph, Attorney-General, 264; Justice of Supreme Court, 264.

McKinley, William, cabinet appointments, 263, 264; cabinet changes, 264 ; retains old cabinet in second administration, 265; assassination of and his cabinet, 265 .

McLean, John, Postmaster-General, 74; Justice of the Supreme Court, 83.

McLean, John, refuses Secretaryship of War, Ir8.

MacVeagh, Franklin, Secretary of the Treasury, 279.

MacVeagh, Wayne, Attorney-General, 233; position, 233; retires, 242.

Madison, James, prepares veto message for Washington (I79I), II; Secretary of State, 4I ; first cabinet, 5 I, 52 .

Manning, Daniel, Secretary of the Treasury, 247; retires, 248.

Marcy, William L., Secretary of War, I29; Secretary of State, I54, I55; Buchanan's opinion of, 155 .

Marine, secretaryship of created, 2; in President's Council, 4.

Marshall, John, proposed AttorneyGeneral, 27, note; named by Adams commissioner to France, 33; Secretary of State, 36.

Mason, George, motion for Executive Council (I787), 5; attitude towards Council, 7 .
Mason, John Y., Secretary of the Navy, I2I ; Attorney-General, 130; Secretary of the Navy again, I34. Maynard, Horace, Postmaster-General, 227.

Meredith, William W., Secretary of the Treasury, I40.

Metcalf, Victor H., Secretary of Commerce and Labor, 270; Secretary of the Navy, 273; retires, 274. Meyer, George von L., PostmasterGeneral, 273; Secretary of the Navy, 280.

Miller, William H. H., AttorneyGeneral, 254.

Monroe, James, Secretary of State, 53; Acting-Secretary of War, 54; quarrels with Armstrong, 56, 57; Secretary of War, 57 ; and Secretary of State also, 58 ; his cabinet, 66,67 ; and J. Q. Adams, 69, 70; on cabinet tenure, 77 .

Moody, William H., Secretary of the Navy, 269; Attorney-General, 270; Associate-Justice, 273.

Morgan, E. D., refuses Secretaryship of the Treasury, I88.

Morgan, Edwin D., Secretary of the Treasury, 24I ; confirmed but declines, 24r.

Morris, Gouverneur, his resolution for Council of State (I787), 4; on President and Council, ' 6 .

Morton, Julius Sterling, Secretary of Agriculture, 259.

Morton, Levi, and Secretaryship of the Treasury, 233; Minister to France, 233.

Morton, Paul, Secretary of the Navy, 270; retires, $27 \mathrm{r}$.

Murray, William Vans, Minister Plenipotentiary to France, 34 . 
Nagle, Charles, Secretary of Commerce and Labor, 280.

Nation, the, on the cabinet, 272.

Navy, department established, 34 .

Navy Department, organization of, $67,68$.

Newberry, Truman H., Secretary of the Navy, 275.

New York, and Garfield's appointments, 233, 234; Garfield and Collectorship of, 236, 237; and Harrison's cabinet, 253.

Noble, John W., Secretary of the Interior, 253.

Olney, Richard, Attorney-General, 259; Secretary of State, 260.

Paulding, James K., Secretary of the Navy, Ior.

Payne, Henry C., Postmaster-General, 269; retires, 27 r.

Pendleton, Edmund, considered for Secretary of State, 26.

Pendleton, George H., his resolution to permit heads of departments to speak in Congress, 302, 303.

Pennsylvania, associated with the Treasury portfolio, 74, 288.

Pickering, Timothy, Secretary of War, 25; his officers, 25; against appointment of Colonel Smith by Adams, 35; dismissed by Adams, 36.

Pierce, Franklin, cabinet appointments, I53, I54, I55; Southern views of, 155, 156, relations, 156, 157; relations with cabinet, 157; character, 157.

Pierrepont, Edwards, Attorney-General, 214; minister to England, 215.

Pinckney, Charles, on President's council of advice (1787), 4.
Pinckney, General Charles Cotesworth, offered Secretaryship of War, 25, note; named by Adams Commissioner to France, 33.

Pinckney, William, Attorney-General, succeeding Rodney, 53.

Platt, Thomas C., recommended as Postmaster-General, 22I ; and Harrison's cabinet, 253.

Poinsett, Joel R., Secretary of War, 99.

Polk, James K., declines Secretaryship of the Navy, I2I; appointments advised by Jackson, I28; cabinet appointments, 129, I30; against Presidential aspirants in his cabinet, I30, I3I ; and Buchanan, I3I, I32; method of consulting cabinet, I32; consults Senate on Oregon Question, 132; originates legislation, I33.

Porter, James M., Secretary of War, I20; unseated by the Senate, I2O. Porter, Peter B., Secretary of War, 76.

Postmaster-General, patronage important, $4 \mathrm{I}$; enters cabinet, 83 ; and the President, 92, 93, 94; ranks with the Secretaries, I49; as party manager, 299.

Post Office, power of the President over, 92, 93, 94.

President, his college of advisors created from cabinet, 9; consultations within and without the cabinet, 9, Io; board of advisors in International Law, etc., proposed for, I5; relation with cabinet discussed, 37; originates legislation, I33; and cabinet under Lincoln, I86.

President, council of discussed in Constitutional Convention (1787), 4 ; resolution for, 4,5 ; rejected, 5 ; 
new resolution for adopted, 5; Mason's resolution, 6, 7 .

Presidential Succession, Johnson's recommendations, 202, 203; provided for, 203.

Preston, William B., Secretary of the Navy, I40.

Preston, W. C., proposed for Secretaryship of the Navy, Io7.

"Princeton," explosion on kills cabinet members, I2I.

Privy council, in Constitutional Convention ( 1787 ), 3 .

Proctor, Redfield, Secretary of War, 253; resigns, 255.

Quincy, Josiah, on cabinet government under Jefferson and Madison, $59,60$.

Ramsay, Alexander, Secretary of War, 227.

Randall, Alexander W., PostmasterGeneral, I93.

Randolph, Edmund, Attorney-General, 9; position of in cabinet strengthened by Genet mission, I4; succeeds Jefferson as Secretary of State, 24; political opinions, 25; and Fauchet, 25; resigns, 26.

Rawlins, John A., Secretary of War, 208; death, 2 I0.

Revolution, American, executive government in, 2 .

Richardson, William A., Secretary of the Treasury, 2I3; ousted, 213.

Robeson, George, Secretary of the Navy, 210.

Roosevelt, Theodore, Assistant Secretary of the Navy, 263; retains McKinley's cabinet, 269; changes in his cabinet, 269, 270, 27I ; and Hitchcock and Wilson, 273.
Root, Elihu, Secretary of War, 265; and Insular Affairs, 265; temporarily retires, 270; Secretary of State, 272; retires, 274.

Rush, Richard, Attorney-General, 55; Secretary of the Treasury, 74 . Rusk, Jeremiah, Secretary of Agriculture, 254.

Rutledge, on President and Council, 6.

Sanborn contracts, 213; scandal with, 2I3, 214.

San Domingo, annexation of, $2 \mathrm{Ir}$; treaty before Grant's cabinet, 2II; 327.

Schofield, John M., Secretary of War, 20I ; retained by Grant, 208. Schurz, Carl, proposals for Hayes' cabinet, 222; Secretary of the Interior, 222; and Civil Service Reform, 226, 227.

Senate, advice of President by, 7; evolution of privy council from precluded, 7; consulted by Polk on Oregon Question, I32; and Lincoln's cabinet, I80, I8I; and Johnson, 198; and Hayes' appointments, 224, 225; forced by public opinion, 225; and the confirmation of the cabinet, 319; President of in President's Council, 4; quarrel with Tyler, I20.

Seward, William H., and Taylor, I4I, I42; his influence, I4I, I42; and Fillmore, I47; Secretary of State, I7I, I72; and Lincoln, I75, I76; his proposals to Lincoln, I76; assumes powers, I76, I77; resigns, I8I; resumes his place, I82; in Johnson's cabinet, 192.

Shaw, Leslie M., Secretary of the Treasury, 269; retires, 273. 
Shelby, Isaac, Secretary of War, 66; declines, 66.

Sherman, on council of advice (I787), 3 .

Sherman, John, Secretary of the Treasury, 222, 225; and Hayes, 226; Secretary of State, 263; retires, 264.

Sherman, W. T., on removal of Stanton, I98; Secretary of War, 2IO, note.

Smith, Caleb B., Secretary of the Interior, 174 ; resigns, 187.

Smith, Charles Emory, PostmasterGeneral, 264; resigns, 269.

Smith, Hoke, Secretary of the Interior, 259.

Smith, Robert, Secretary of the Navy, 42; Secretary of State, 52; resigns, 52; Minister to Russia, 52. Smith, Samuel, opposes transfer of Gallatin to State Department, 5I. Solicitors, or assistant attorneysgeneral in Department of Justice, I5.

Solicitor-General, provided for, 2I7; duties, 217.

South, the, demands representation in the cabinet of Van Buren, 99; members from in Taylor's cabinet, I4I ; and Lincoln's cabinet, I73; has a member of Hayes' cabinet, 223; and Garfield's cabinet, 235; in Cleveland's cabinet, 247; must be represented in the cabinet, 264 . Southern Democrats, in Tyler's cabinet, I2I.

Speaker, the, in President's Council, 4.

Speed, James, Attorney-General, 187; resigns, 192.

Stanbery, Henry, Attorney-General, I93.
Stanton, Edwin M., Attorney-General, 165; supersedes Cameron, I77; and Lincoln, I78, I79, I85; removal of, I92; and Johnson, I93, 194, I97; suspended by Johnson, I97; removed, I98; resigns, 201.

State, Assistant-Secretary of, office created, I49.

State, department of established, 8. State, Secretary of should have been consulted on certain Indian despatches (I792), I2; position under Washington, 24; proposals for successor to Randolph, 26, note; priority, 45 ; does not issue report, 307 ; position of under the President, 3I4, 3I5, 3I6.

Stewart, Alexander T., Secretary of the Treasury, 208; disability, 208. Stimson, Henry L., Secretary of War, 28I.

Stoddert, Benjamin, Secretary of the Navy, 34.

Straus, Oscar S., Secretary of Commerce and Labor, 273.

Supreme Court, justices of consulted by President on International Law, I4, I5.

Taft, Alphonso, Secretary of War, 215; Attorney-General, 215.

Taft, William H., Secretary of War, 270 ; retires, 274; cabinet appointments, 279.

Tallmadge, N. P., offered seat in Harrison's cabinet, I07.

Taney, Roger B., nomination for Secretary of the Treasury rejected, 94.

Taylor, Zachary, intentions, I39; and Crittenden, I39, I40; appointments, I40; advised in cabinet appointments, 140; intended appointments before death, I 43 . 
Tazewell, Littleton W., offered Secretaryship of State, $\mathbf{8 2}$.

Teller, Henry M., Secretary of the Interior, 242.

Tenure of Office Act, members of cabinet and, 194, 195, 196, I97; President Johnson and, 200, 20I; amended, 203.

Thomas, Philip F., Secretary of the Treasury, I64; resigns, 167.

Thompson, Richard W., Secretary of the Navy, 223; resigns, 227.

Tod, David, declines Secretaryship of the Treasury, I85.

Tompkins, Daniel D., declines to be Secretary of State, 57, 58.

Thompson, Jacob, Secretary of the Interior, 162, 163; resigns, I67.

Toucey, Isaac, Attorney-General, I34; Secretary of the Navy, I62.

Tracy, Benj. F., Secretary of the Navy, 253.

Treasury, department of established ( I789), 8.

Treasury, Secretary of to consider certain Indian despatches (I792), 12; functions assumed under Hamilton, 20, 2I ; criticized, 22; and Congress, 44; relation to the President and Congress, 89, 90, 92 ; Whig caucus would have him appointed by Congress, II3; amendment to Constitution proposed, II3; candidates for ( 1865 ), I88; precedense of, 288; position of in the cabinet, 316.

Trescott, William F., Secretary of State, I65.

Tyler, John, retains Harrison's cabinet, III; his cabinet considers his financial measures, 112 , 113 ; four members of his cabinet resign, II 3 ; financial measures and relations with Congress, III, II2, II3 ; Con- gress and, II3; Ewing's views of, II4; his "Kitchen" cabinet, II5; relations with his cabinet, II4, II5; conduct discussed, II7; alliances, II7; new appointments, II6, II8, I19; quarrel with the Senate, I20; cabinet appointments, I2I.

Tyner, James M., Postmaster-General, 216; First Assistant-Postmaster-General, 223.

Upshur, Abel P., Secretary of the Navy, II8; Secretary of State, I20; killed, I2I.

Usher, John P., Secretary of the Interior, I87; retirement, I88, I9I.

Van Buren, Martin, Secretary of State, 82 ; resigns, 88; his advisors outside the cabinet, I0o; cabinet appointments, IOO, IOI ; his cabinet characterized, IOI, IO2.

Vice-President, meets with cabinet (I79I), I2; not in the cabinet, 320. Vilas, William F., Postmaster-General, 247; Secretary of the Interior, 248 .

Virginia, executive council influences Washington's cabinet, I3.

Wade, B. F., "contrives" a cabinet as possible successor to Johnson, 202.

Walker, Robert J., Secretary of the Treasury, I29.

Wanamaker, John, Postmaster-General, 254.

War, Department of, established (I789), 8; condition of (I860186I), I77; and the war with Spain, 264, 265; controversies over, 265 ; and Insular affairs, 265.

War, secretaryship of created (I78I), 2; in President's Council, 
4; Secretary of apparently not consulted on Bank Act (I79I), II ; secretaries proposed, 27; military men made secretary of war, 298.

Washburne, Elihu B., Secretary of State, 209.

Washington, G., visits Senate for advice, 7 ; relations with members of cabinet, 13; does not use word, "cabinet," $\mathrm{r}_{5}$; against different parties in the cabinet, 26; and the appointment of the major-generals by Adams, 34 .

"Watch-dog of the Treasury," 209. Webster, Daniel, Secretary of State, ro5, 106; remains in Tyler's cabinet, II4, II5, II6; resigns, II9; position, Ir9, I20; resigns from Fillmore's cabinet, 148 .

Weed, Thurlow, influence in politics of, 85 .

Welles, Gideon, on formation of Lincoln's cabinet, I7I; Secretary of the Navy, r73.

Whigs, improve the cabinet, 149.

Whitney, William C., Secretary of the Navy, 247.

Wickersham, George W., AttorneyGeneral, 280.
Wickliffe, Charles A., PostmasterGeneral, Ir8.

Wilkins, William, appointed Secretary of War, rzo.

Williams, George H., Attorney-General, 213.

Wilson, on single magistrate, 3,4 .

Wilson, James, Secretary of Agriculture, $264 ; 280$.

Wilson, William L., PostmasterGeneral, 260.

Windom, William, Secretary of the Treasury, 234, resigns, 24r; Secretary of Treasury under Harrison, 253; dies, 255.

Wirt, William, Attorney, General, 67.

Wolcott, Oliver, Secretary of the Treasury, 25; resigns, 36 .

Woodbury, Levi, Secretary of the Treasury, 94; his "rotation" principle, roo; and offers to resign, 100. Wright, Luke E., Secretary of War, 274.

Wright, Silas, declines Secretaryship of the Treasury, 128.

Wynne, Robert J., Postmaster-General, 27 r. 


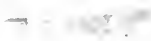

$\therefore$

is ita

(1) 



\section{RETURN CIRCULATION DEPARTMENT}

IO $\rightarrow 202$ Main Library

\begin{tabular}{l|l|l}
\hline $\begin{array}{l}\text { LOAN PERIOD 1 } \\
\text { HOME USE }\end{array}$ & 2 & 3 \\
\hline 4 & 5 & 6 \\
\hline
\end{tabular}

ALL BOOKS MAY BE RECALLED AFTER 7 DAYS

Renewals and Recharges may be made 4 days prior to the due date.

Books may be Renewed by calling $642-3405$.

\section{DUE AS STAMPED BELOW}

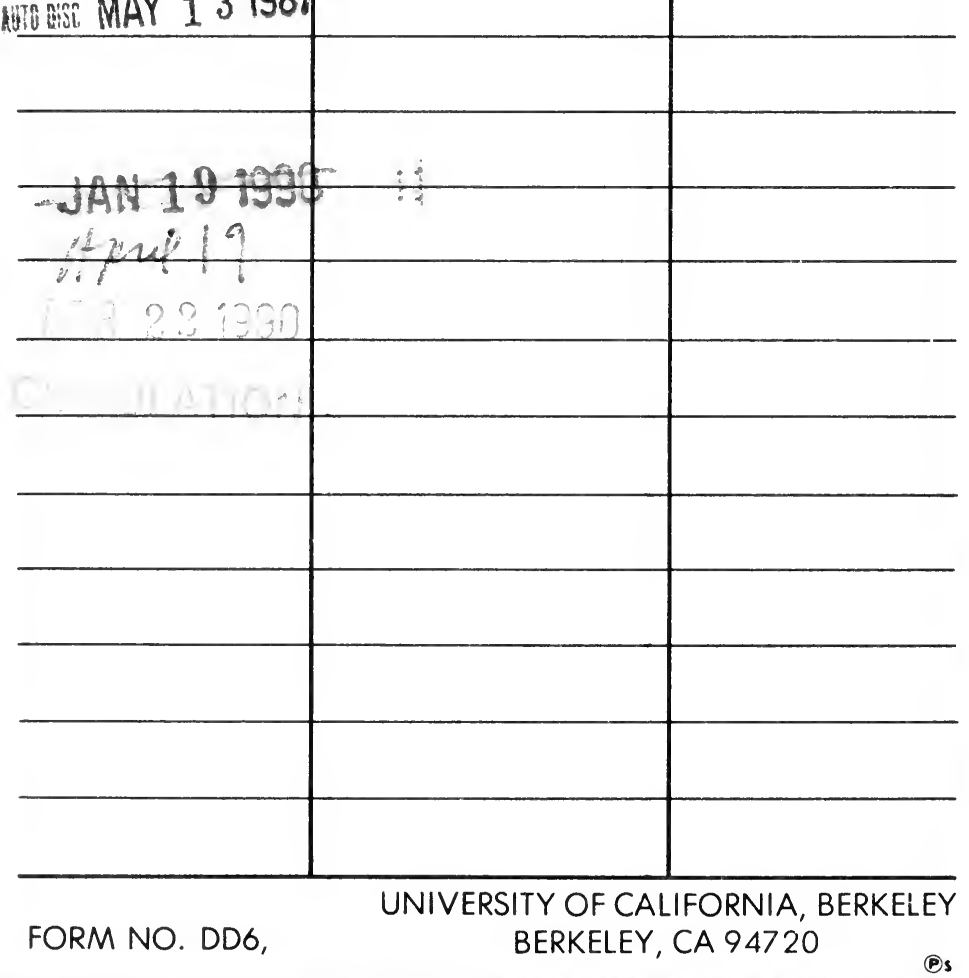


YC 39575
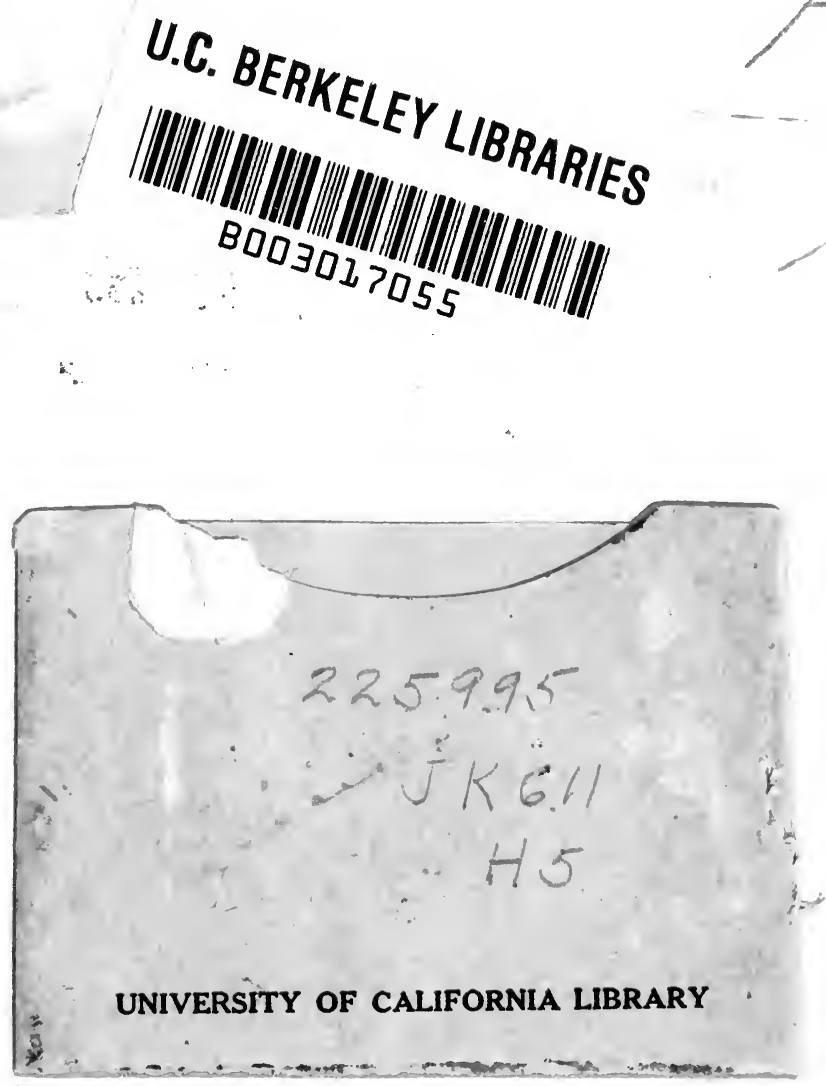

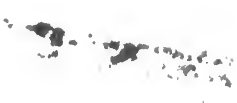


